\title{
DISTRIBUTION OF MARINE PALYNOMORPHS IN SURFACE SEDIMENTS, PRYDZ BAY, ANTARCTICA
}

\author{
Claire Andrea Storkey \\ A thesis submitted to Victoria University of Wellington \\ in fulfilment of the requirements for the degree \\ Masters of Science in geology \\ School of Earth Sciences \\ Victoria University of Wellington
}

April 2006 


\begin{abstract}
Prydz Bay Antarctica is an embayment situated at the ocean-ward end of the Lambert Glacier/Amery Ice Shelf complex East Antarctica. This study aims to document the palynological assemblages of 58 surface sediment samples from Prydz Bay, and to compare these assemblages with ancient palynomorph assemblages recovered from strata sampled by drilling projects in and around the bay.
\end{abstract}

Since the early Oligocene, terrestrial and marine sediments from the Lambert Graben and the inner shelf areas in Prydz Bay have been the target of significant glacial erosion. Repeated ice shelf advances towards the edge of the continental shelf redistributed these sediments, reworking them into the outer shelf and Prydz Channel Fan. These areas consist mostly of reworked sediments, and grain size analysis shows that finer sediments are found in the deeper parts of the inner shelf and the deepest areas on the Prydz Channel Fan. Circulation within Prydz Bay is dominated by a clockwise rotating gyre which, together with coastal currents and ice berg ploughing modifies the sediments of the bay, resulting in the winnowing out of the finer component of the sediment.

Glacial erosion and reworking of sediments has created four differing environments (Prydz Channel Fan, North Shelf, Mid Shelf and Coastal areas) in Prydz Bay which is reflected in the palynomorph distribution. Assemblages consist of Holocene palynomorphs recovered mostly from the Mid Shelf and Coastal areas and reworked palynomorphs recovered mostly from the North Shelf and Prydz Channel Fan. The percentage of gravel to marine palynomorph and pollen counts show a relationship which may reflect a similar source from glacially derived debris but the percentage of mud to marine palynomorph and pollen counts has no relationship.

Reworked palynomorphs consist of Permian to Eocene spores and pollen and Eocene dinocysts which are part of the Transantarctic Flora. Holocene components are a varied assemblage of acritarchs, dinoflagellate cysts (dinocysts), prasinophyte algae, red algae and large numbers of Zooplankton sp. and foraminifera linings. In situ dinocysts are dominated by the heterotroph form Selenopemphix antarctica and none 
of the Holocene dinocyst species found in Prydz Bay have been recorded in the Arctic. In contrast acritarchs, prasinophytes and red algae are all found in the Arctic and reflect a low salinity and glacial meltwater environment. Comparison with modern surface samples from the Arctic and Southern Ocean show there is a strong correlation to reduction in the autotroph:heterotroph dinocyst ratio with increasing latitude.

Todays assemblage of marine palynomorphs are more complex than those recorded in ancient assemblages and there is a lower level of reworked material. Acritarchs (Leiosphaeridia spp. Sigmopollis sp.) and prasinophytes (Cymatiosphaera spp. Pterospermella spp. Tasmanites spp.) are recorded in the ancient record in Antarctica as well as surface sediments in Prydz Bay, but there are very low numbers of Leiosphaeridia spp. and Sigmopollis spp. present today in comparison to the ancient record. Dinocysts in situ and recovered in Prydz Bay are endemic to the Antarctic but have not been recorded in the ancient record. 


\section{CONTENTS}

Abstract $\quad$ i

Contents $\quad$ iii

List of figures vii

List of tables viii

Acknowledgments ix

1.0 Introduction 1

1.1 Aim of this study 1

1.2 Evolution of Prydz Bay 2

1.3 Location and setting 3

$\begin{array}{lll}1.4 & \text { Previous work } & 7\end{array}$

1.4.1 Prydz Bay 7

$\begin{array}{lll}\text { 1.4.2 Southern Ocean studies } & 7\end{array}$

1.4.3 Arctic studies $\quad 8$

2.0 Prydz Bay Marine Environment 11

2.1 Circulation in Prydz Bay 11

2.2 Water masses in Prydz Bay 11

2.3 Circulation beneath the Amery Ice Shelf 14

$\begin{array}{lll}2.4 & \text { Sea Ice inhabitants } & 15\end{array}$

3.0 Methods and Results - Palynology 20

$\begin{array}{lll}3.1 & \text { Introduction } & 20\end{array}$

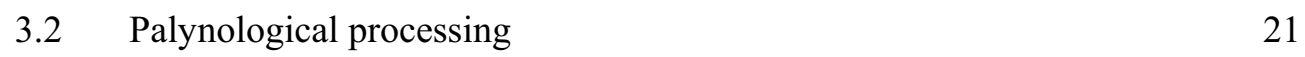

3.2.1 Microscope and camera technique 22

3.2.2 Counting method 22

3.2.3 Grains per gram $(\mathrm{g} / \mathrm{g}) \quad 23$

3.2.4 Contamination 23

$\begin{array}{lll}3.2 .5 & \text { Oxidation } & 23\end{array}$ 


\subsection{Results - Palynology}

3.3.1 Introduction 24

3.4 Acritarchs 24

3.4.1 Acanthomorphitae 25

3.4.2 Leiosphaerida 25

3.4.3 Sigmopollis 25

3.4.4 Sphaeoromorphs 25

3.5 Dinoflagellate cysts 25

3.5.1 Selenopemphix antarctica 26

3.5.2 Protoperidinium sp. 2

3.5.3 Cryodinium sp 27

$\begin{array}{lll}3.5 .4 & \text { Other dinocysts } & 27\end{array}$

$\begin{array}{lll}3.6 & \text { Prasinophycean algae } & 27\end{array}$

3.6.1 Cymatiosphaera sp. 1 and sp. 2

3.6.2 Tasmanites and Pterospermella 28

3.7 Red algae 28

$\begin{array}{lll}3.8 & \text { Unknowns } & 29\end{array}$

3.9 Zooplankton $\quad 29$

3.9 .1 Tintinnids 29

3.9.2 Zooplankton sp. 29

3.10 Foraminiferan linings $\quad 29$

$\begin{array}{lll}3.11 & \text { Insect parts } & 30\end{array}$

3.12 Egg cases $\quad 30$

$\begin{array}{lll}3.13 & \text { Reworked palynomorphs } & 30\end{array}$

3.13.1 Reworked dinoflagellate cysts $\quad 30$

$\begin{array}{ll}3.13 .2 \text { Pollen } & 31\end{array}$

3.14 Results for oxidised samples 31

3.15 Palynomorph distribution 31

3.16 Total abundance for Holocene palynomorphs 32

3.17 Other palynomorph distributions $\quad 35$

3.18 Reworked v Holocene dinoflagellate cysts 38

3.19 Terrestrial material (reworked) 42

3.20 Total Holocene and reworked palynomorphs 42 


\subsection{Method and Results - Grain Size 58}

$\begin{array}{lll}4.0 & \text { Introduction } & 58\end{array}$

4.1 Method 58

$\begin{array}{lll}4.2 & \text { Results } & 59\end{array}$

$\begin{array}{lll}4.3 & \text { Interpretation } & 65\end{array}$

4.4 Prydz Channel Fan $\quad 65$

$\begin{array}{lll}4.5 & \text { North Shelf } & 71\end{array}$

4.5.1 Four Ladies and Fram Banks 71

4.5.2 Northern Prydz Channel 72

$\begin{array}{lll}4.6 & \text { Mid shelf } & 72\end{array}$

4.6.1 Prydz Channel 72

4.6.2 The Amery Depression 72

$\begin{array}{lll}4.7 & \text { Coastal } & 73\end{array}$

4.7.1 Lambert and Nanok Deeps 73

$\begin{array}{lll}\text { 4.7.2 Svenner Channel } & 74\end{array}$

$\begin{array}{lll}4.8 & \text { Mud distribution and palynomorph abundance } & 74\end{array}$

$\begin{array}{lll}5.0 & \text { Discussion } & 76\end{array}$

$\begin{array}{lll}5.0 & \text { Introduction } & 76\end{array}$

5.1 Palynomorph assemblages in Prydz Bay 77

5.2 Comparison with other modern assemblages 80

5.3 Ancient and modern assemblages 83

5.3.1 Prydz Bay Ocean Drilling Program 85

5.3.2 Reworked surficial sediments in the Ross Sea 89

$\begin{array}{lll}\text { 6.0 Conclusions } & 90\end{array}$

$\begin{array}{ll}\text { References cited } & 92\end{array}$ 


\section{APPENDICES}

$\begin{array}{lll}\text { Appendix A } & \text { Master spreadsheet } & 103\end{array}$

Individual output data 58 sheets on 28 pages 109

Tables for palynomorphs geographic distribution $\quad 137$

$\begin{array}{lll}\text { Appendix B } & \text { Sediment description from raw samples } & 143\end{array}$

Grain size analysis output data includes depths 146

$\begin{array}{lll}\text { Appendix C List of Species } & 164\end{array}$

Appendix D Maps displaying positions for: 173

$\begin{array}{ll}\text { Prasinophytes, Acritarchs, } & 173\end{array}$

$\begin{array}{ll}\text { Egg cases, Sphaeromorphs, } & 174\end{array}$

$\begin{array}{ll}\text { Unknowns and Leiospheres } & 175\end{array}$ 


\section{List of Figures}

1.1 Map showing the relative positions of India/Antarctica 3

1.2 Map showing the Prydz Channel and Prydz Channel Fan 5

1.3 Map displaying the Coastal, Mid Shelf, North Shelf and Fan 6

2.1 Oceanography of Prydz Bay surface currents 12

2.2 Circulation beneath the Amery Ice Shelf 15

2.3 Microbial habitats within pack ice and land fast ice communities 18

2.4 Past environmental conditions triggering palaeoproductivity 19

3.1 Graph and map for total Holocene g/g 33

3.2 Graph and map for Holocene assemblages g/g 34

3.3 Map displaying positions of Zooplankton sp. g/g 36

3.4 Map displaying positions of foraminiferan linings $\mathrm{g} / \mathrm{g} \quad 36$

3.5 Map displaying positions of Red Algae g/g 37

3.6 Map displaying positions of Cymatiosphaera sp. 2

3.7 Map displaying contours for salinity grid 39

3.8 Graph and map for Holocene dinocysts $\mathrm{g} / \mathrm{g} \quad 40$

3.9 Graph and map for reworked dinocysts g/g 41

3.10 Graph and map for terrestrial palynomorphs g/g 44

3.11 Graph and map for absolute abundance g/g 45

4.1a Map for contours of mud percent Harris et al (1998) 63

4.1b Map for contours of gravel proportions from this study 63

4.2 Examples of histograms from grain size this study 64

4.3 Map displaying possible lithology from grain size analysis 66

4.4 Map displaying depth of each sample $\quad 67$

4.5a Map displaying mud proportions for each sample 68

4.5b Map displaying sand proportions for each sample $\quad 69$

4.5c Map displaying gravel proportions for each sample $\quad 70$

4.6 Graphs displaying \% mud, \% gravel vs pollen and dinocysts 75

5.1 Dinocyst diversity comparing ancient and modern 84

5.2 Map showing ODP sites on Prydz Bay shelf, Fan and Wild Drift 86 


\section{List of Tables}

4.1 Table displaying raw count in location areas for palynomorphs $\quad 60$

5.1 Table displaying Antarctic and Arctic palynomorphs 82

5.2 Table displaying Trans Antarctic Flora 88

\section{List of Plates}

1 Acritarchs 46

2 Acritarchs 47

3 Dinocysts 48

4 Dinocysts 49

5 Dinocysts and Prasinophycean algae 50

6 Prasinophycean algae $\quad 51$

7 Prasinopycean algae, red algae and foram linings 52

$8 \quad$ Foram linings and zooplankton sp. 53

9 Zooplankton sp. and reworked dinocysts 54

10 Reworked dinocysts and unknowns 55

11 Unknowns, egg cases and insect parts 56

12 Egg cases and unknowns $\quad 57$ 


\section{ACKNOWLEDGMENTS}

I would like to thank my supervisor Mike Hannah who has encouraged and supported me throughout. We needed a lot of patience to get this study underway and finally succeeded thanks Mike.

Special thanks to Peter Barrett for his helpful suggestions, input and interest in my grain size analysis chapter.

Thanks to Phil O'Brien and Geoscience Australia for the sediment samples they supplied. They made me feel welcome in Canberra.

Thanks to Chris Clowes for his encouragement and help with identification and to the overseas experts that answered my emails with helpful suggestions for identification: Anne de Vernal, Amy Leventer, Andrew McMinn, Karin Beaumont, John Gibson, Catherine Stickley and locally Helen Neil, and Hugh Grenfell.

Thanks to VUW technical staff for their support in the labs Stephen Edgar and John Carter

Thanks to Chris Brookes and his GIS team in encouraging and supporting me with arcview mapping (includes students who gave great input).

Finally many thanks to my family for their support and patience with me, in particular thanks Ian for your support with my excel program and proof reading, thanks Corin for reading and trying to make sense of chapter 3, and thanks Angela and Gavin for your support and encouragement over the past 2 years, and telling me yes I can do it! 


\section{CHAPTER 1 INTRODUCTION}

Antarctic marine and terrestrial palynomorphs are commonly used in studies aimed at increasing our understanding of past climate. Published studies include Deep Sea Drilling Project (DSDP) (Kemp, 1975), MSSTS-1 drill hole McMurdo Sound (Truswell, 1986), CIROS-1 Drillhole (Hannah, 1997), and the Cape Roberts Project (Hannah et al. 1998, Wrenn et al. 1998, Hannah et al. 2000, Hannah et al. 2001a). Studies of the ancient record in Prydz Bay include ODP sites 1165 (Hannah, 2005, McPhail \& Truswell, 2004a), 1167 and 1166 (McPhail \& Truswell, 2004b).

A combined program involving the Australian Geological Survey Organisation (now Geoscience Australia), Australian Antarctic Co-operative Research Centre (CRC) and Australian National Antarctic Research Expeditions (ANARE) resulted in three cruises (1993, 1995 \& 1997) investigating several key areas along the Antarctic east coast. The cruises included a marine geophysical survey and sediment sampling programmes. This was done to promote a better understanding of global climate change through the studies of modern sediment transport and the organisms contained in them, and relate this understanding to the ancient sedimentary record (O'Brien et al. 1995). The surface sediment samples used in this study are from these cruises.

\subsection{Aims of this study}

This study documents the palynology of Prydz Bay surface sediments. It aims to:

1. Document the palynomorph assemblages contained in the samples.

2. Understand the distribution of palynomorphs, both in situ and reworked in terms of physical characteristics of the bay which include:

a. Water depth and currents

b. Sediment supply

3. Compare the modern assemblages with those recovered from the ancient records (e.g. Hannah et al. 2000, Hannah, 2005, Wrenn et al. 1998) and assess the possibility of any modern analogues with those of the past. 
In the ancient record, the number and type of terrestrial palynomorphs found and comparison of changes to marine palynomorph assemblages within sedimentary cycles allow inferences to changes to the environment occurring during that time. ODP investigations on Wild Drift site 1165 Prydz Bay (Hannah, 2005) show that palynomorph numbers have changed in accordance with the types of conditions encountered in the past. Expansion of the Amery Ice Shelf under cooler conditions may have caused marine palynomorphs to be fewer in numbers. As conditions warmed and the ice shelf retreated the palynomorphs increased in numbers (Hannah, 2005). Today the full retreat of the Amery Ice Shelf from the embayment has altered the environment of the bay significantly. The question to be asked is has it also changed the palynomorph assemblages found there today from assemblages found in similar conditions of ice shelf retreat in the past?

\subsection{Evolution of Prydz Bay}

The origin of Prydz Bay in East Antarctica is associated with the Mesozoic break up of Gondwana. Figure 1.1 shows a reconstruction that juxtaposes Prydz Bay with the east coast of India (Cooper et al. 1991, Davey, 1985, Hambrey et al. 1991). Stagg, (1983) places the Lambert Graben/Amery area adjacent to Mahanadi Graben, one of two grabens at right angles to the coast beneath the Indian basins. He describes these grabens as a failed rift arm of a triple junction that may have been created in the Late Palaeozoic to Early Mesozoic during the separation of the continents (Davey, 1985, Anderson, 1999). Substantial sediment thicknesses within the Lambert Graben may date back to the Permian, and exposed sediments similar to those in Mahanadi Graben can be found in the Beaver Lake area of the Prince Charles Mountains (Cooper et al. 1991, Hambrey, 1991, Hambrey et al. 1991).

The Lambert Glacier/Amery ice shelf drainage basin is estimated to cover $\sim 1,090,000 \mathrm{~km}^{2}$ (Allison, 1979, Hambrey et al. 2000). The Lambert Graben is formed largely in Precambrian metamorphic basement and the subglacial floor lies below sea level and extends south for almost $700 \mathrm{~km}$. The Lambert Glacier/Amery Ice Shelf now occupies the area but it was once a fjord with a depth reaching $3000 \mathrm{~m}$ and a width of $\sim 50 \mathrm{~km}$ (Hambery, 1991). The Lambert Glacier is bordered in the 
west by the partially exposed Prince Charles Mountain complex with Mt Menzies reaching a height of 3,355 m above sea level (Stagg, 1983, Hambery, 1991). To the East of the Lambert Graben the Mawson Escarpment protrudes and a deep basement depression beneath the Escarpment is part of the main Graben.

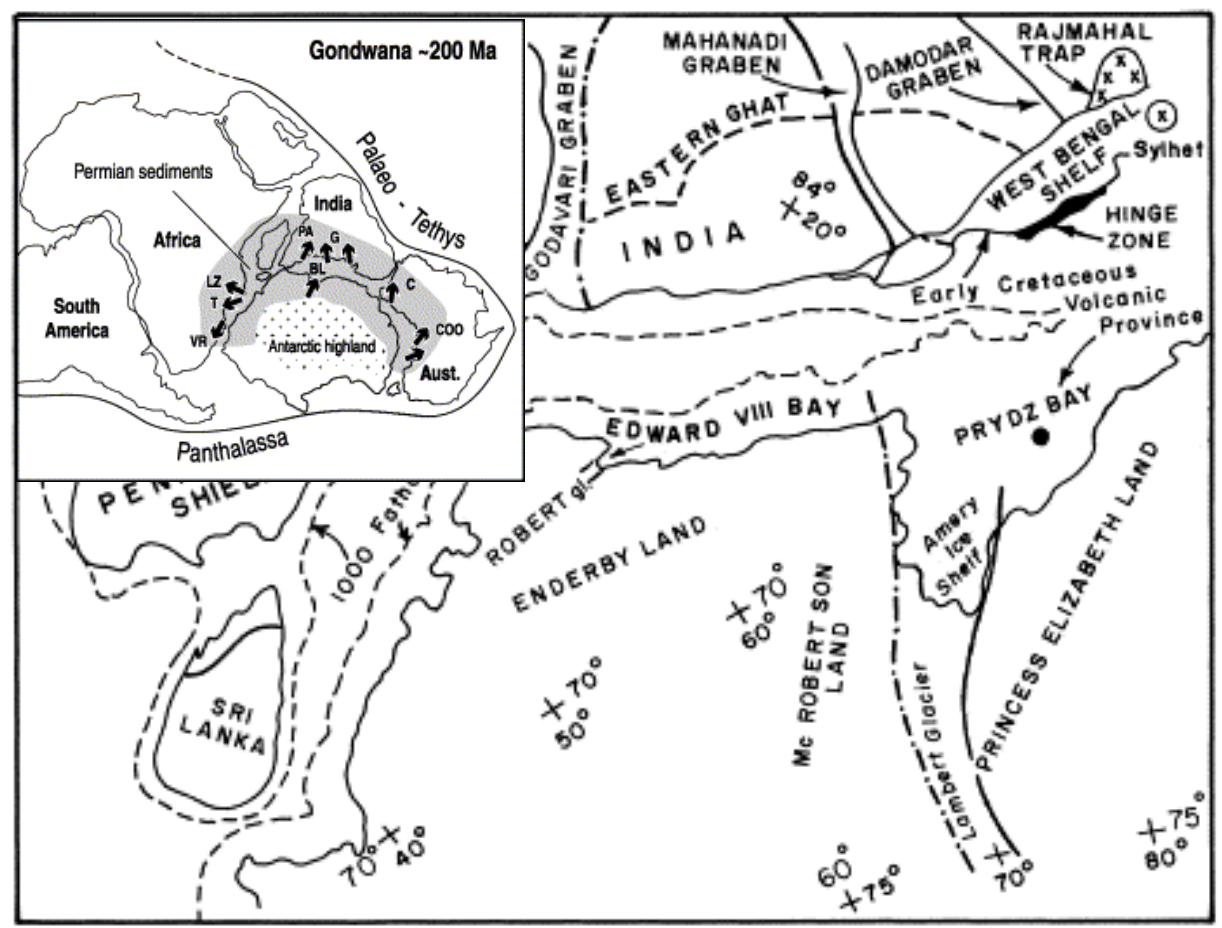

Fig. 1.1: The relative positions of India and Antarctica showing the respective position of Gondwana rift valleys during the early Jurassic. Black dot indicates the probably position of the Kerguelen hotspot. Dot dash lines indicate the master faults of the rift basins of the two continents. Lambert and Mahanadi basins are conjugate structures and show similar crustal structures. Insert shows Gondwana $\sim 200$ Ma (Mishra et al. 1999).

\subsection{Location and setting}

Prydz Bay is an embayment situated at $76^{\circ} \mathrm{E}, 68^{\circ} \mathrm{S}$ and lies at the ocean ward end of the Lambert Graben/Amery Ice Shelf. The inner shelf is underlain by a sedimentfilled rift basin containing more than $5 \mathrm{~km}$ of Early Cretaceous and older continental rift strata, and Cooper et al. (1991) consider it to be separate from the major Lambert Rift Graben. Data from gravity, magnetic and seismic refraction indicate maximum sediment of the inner shelf thicknesses are 5-12 km (Cooper et al. 1991). Sediment transport in the present Antarctic ice sheet occurs from the interior in a basal layer that contains $5-8 \%$ sediment; however in the past, erosion by grounded ice 
overdeepened the inner shelf and progradation and aggradation occurred fairly evenly across the bay. During the late Neogene cooler conditions developed the Prydz Channel Ice Stream (fig 1.2) which carried debris to the shelf edge and built out the Prydz Channel Fan (Cooper et al. 2004). These past glacial processes have created differing environments within the embayment which is reflected in the palynomorph distribution. The geographical areas of Coastal, Mid Shelf, North Shelf and Prydz Channel Fan are colour highlighted in figure 1.3 which reflect the differing environments of these past glacial processes.

Coastal geographic areas includes depressions in the south western corner of the bay of up to $1000 \mathrm{~m}$, these are the Lambert and Nanok Deeps. On the eastern side of Prydz Bay off the Ingrid Christensen Coast is the elongated trough of the Svenner Channel which is also part of the Coastal area and is up to 1,000 $\mathrm{m}$ deep but with several shallower saddles along its length (O'Brien et al. 1999, 2003, Passchier et al. 2003).

Mid Shelf area contains the broad topographic basin of the Amery Depression, 600$800 \mathrm{~m}$, which deepens shoreward. Along the western edge of the Amery Depression the elongate deep of the Prydz Channel is also Mid Shelf and is $150 \mathrm{~km}$ wide and 500-600 $\mathrm{m}$ deep and extends to the edge of the continental shelf (O'Brien et al. 1999, 2003, Passchier et al. 2003).

North Shelf area includes the shallower part of the Prydz Channel near the continental shelf edge. Northeast of the Amery Depression along the shelf edge the shelf shallows to 200-300 m, and the Four Ladies Bank to the east of Prydz Channel and Fram Bank to the West, are also included in the North Shelf area (O'Brien et al. 1999, 2003; Passchier et al. 2003).

Prydz Channel Fan is included as its own geographic area and is $166 \mathrm{~km}$ across and extends $90 \mathrm{~km}$ seaward from the shelf break where the surface slopes at $2.0^{\circ}$ and is a major sediment depocentre (Harris et al. 1998). 


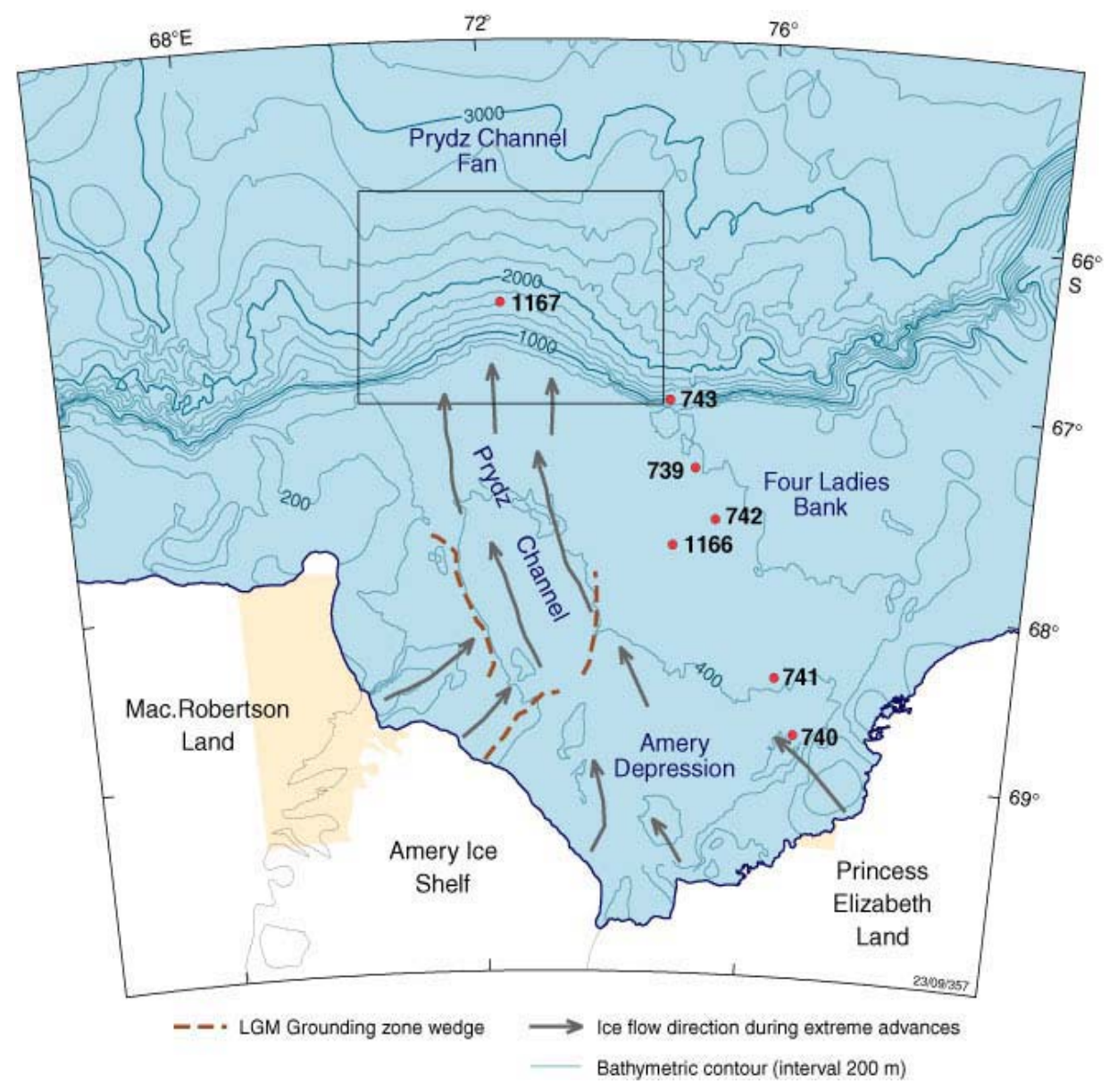

Fig. 1.2: Map of Prydz Bay showing the location of the Prydz Channel Trough Mouth Fan, Prydz Channel, and locations of Leg 119 739-743 and Leg 188 1166-1167. Last Glacial Maximum grounding zone wedges are shown after Domack et al. (1998). Arrows indicate ice flow directions during post-late Miocene extreme advances of the Lambert Glacier/Amery Ice Shelf system (modified from O’Brien and Harris, 1996 by O’Brien, 2004). 


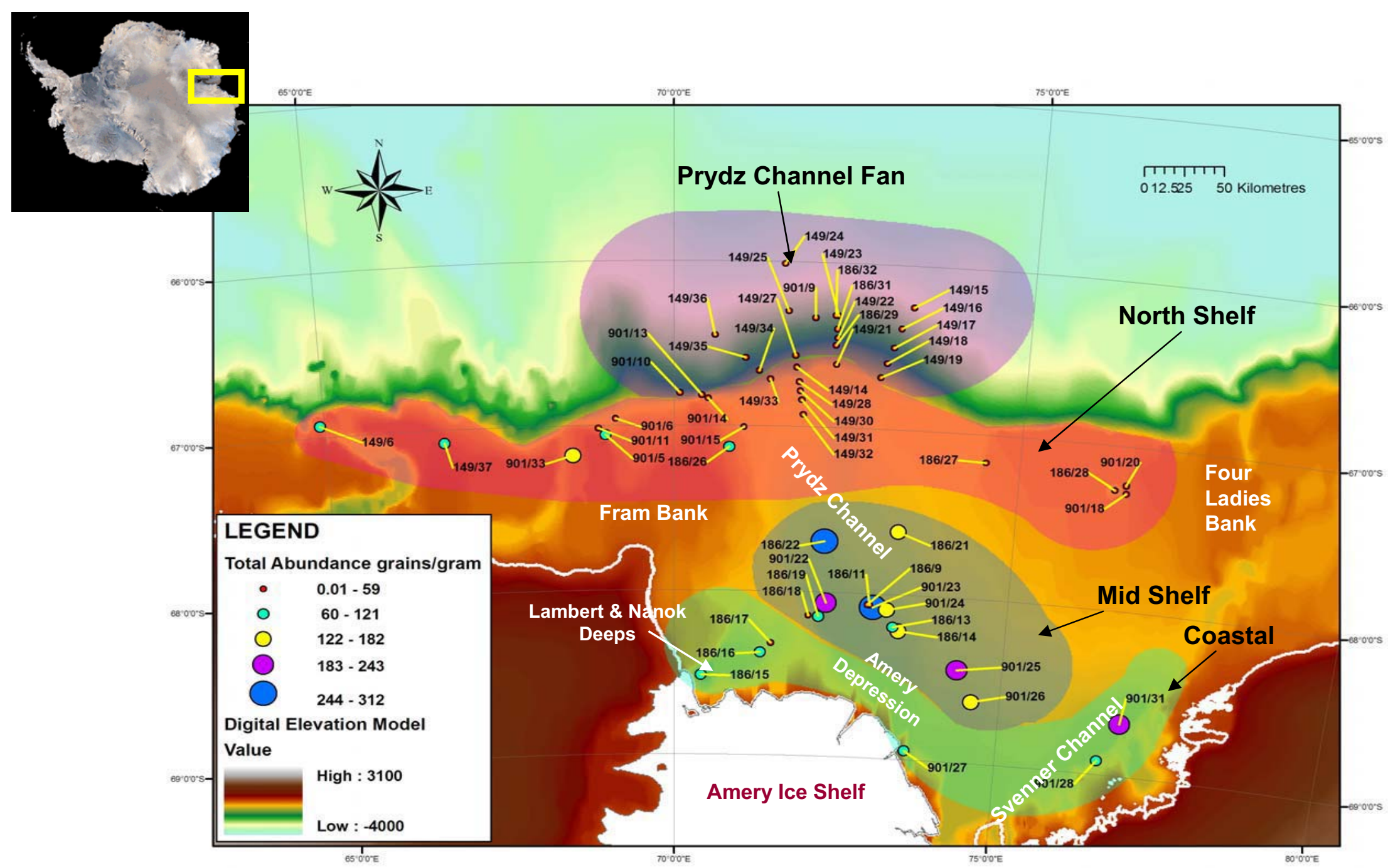

Fig 1.3: Geographical areas have been named as Prydz Channel Fan, North Shelf (includes Fram and Four Ladies Banks and the North Prydz Channel), Mid Shelf (includes Prydz Channel and Amery Depression), and Coastal (includes Lambert and Nanok Deeps and the Svenner Channel). Sample numbers have a yellow leader attached to each coloured circle and are included to show the distribution pattern of palynomorphs in each geographical area. 


\subsection{Previous Work}

\subsubsection{Prydz Bay}

Diatoms and foraminifera are the only micro-organisms previously studied from the surface sediments of Prydz Bay. Initially, Quilty (1985) investigated foraminifera in surface sediments within Prydz Bay but the first systematic sampling programme was completed by Franklin (1991), who reported on the foraminiferan and diatom content of the surface sediments. Today surface sediments are dominated by large diatom populations in the north west Fram Bank area within Prydz Bay. Further work by Taylor, McMinn and Franklin (1997), Quilty (1985), Franklin (1991), Franklin et al. (1995), Taylor \& Leventer (2003), Taylor et al. (1997), studied the distribution of diatoms in surface sediments of Prydz Bay and recognised four diatom assemblages. They concluded that the environmental variables associated with latitude which includes sea-ice, horizontal water circulation and the Prydz Bay gyre play a major role in the types of diatom assemblages found within the bay.

\subsubsection{Southern Ocean studies}

Harland et al. (1998), in a transect of the Southern Ocean from the Falkland Trough to the Weddell Sea, found that abundances for dinoflagellate cysts (dinocysts) did not exceed 364 grains per gram of sediment between latitudes $50^{\circ} \mathrm{S}$ to $60^{\circ} \mathrm{S}$. From $60^{\circ}$ $S$ to higher latitudes the cysts per gram of sediment declined to $<23$ grains per gram and diversity was lower (maximum of six species) than the Antarctic Circumpolar Current. Marret \& de Vernal (1997), transected the Southern Indian Ocean from the Subtropical domain to the Continental Antarctic domain between latitudes $30^{\circ} \mathrm{S}$ to $68^{\circ} \mathrm{S}$. Their results show more than 20 taxa present in assemblages from the Subtropical domain and less than 10 taxa (minimum of 3) recorded in the SubAntarctic and Antarctic domains. In addition to dinocysts, other palynomorphs present included Acritarchs, tintinnid cysts and loricae, Halodinium, and Prasinophyceae (Cymatiosphaera-type spp, Tasmanites spp). Esper \& Zonneveld (2002) concluded that gonyaulacoid cysts tended to dominate the Subtropical Zone with their highest abundance at $\sim 45^{\circ} \mathrm{S}$ at 500 grains per gram and were present till approximately $50^{\circ} \mathrm{S}$. The protoperidinioid cysts dominated from $40^{\circ} \mathrm{S}$ in the SubAntarctic and Polar Front Zones with a high of 2,000 grains per gram noticeably 
falling to $<250$ grains per gram at $60^{\circ} \mathrm{S}$. Those results were clearly a higher abundance than Harland et al. (1998) had recorded four years earlier.

Harland \& Pudsey (1999) studied results from sediment traps deployed in the Bellingshausen, Weddell and Scotia seas and compared them with surface sediments recovered nearby. There was a very low dinocyst assemblage recovered from coretop samples $(<10-300 \mathrm{~g} / \mathrm{g})$ compared to the sediment traps $(500-3,000 \mathrm{~g} / \mathrm{g})$ which varied according to their position within the transect. The sediment traps were set above and within the nepheloid layer and within and to the north of the maximum sea ice limit and the core top samples were recovered from within $3 \mathrm{~km}$ of the corresponding sediment traps. Allochthonous elements may be responsible for part of the material captured by sediment traps. These findings may also reflect the uncertainty of core top sample ages and current winnowing of the sediment and factors relating to oxidation and dilution due to the length of time cysts may have lying at the sediment water interface.

Dinocysts may be heterotrophic, that is without photosynthetic pigments, autotrophic with photosynthetic pigments, or mixotrophic which enables them to supplement their photosynthetic capability by taking up organic substances (McMinn \& Scott 2005). Gonyaulacoid dinoflagellates inhabit warmer and deeper waters and protoperidinioid dinoflagellates prefer cooler temperatures in high latitudes (Mudie and Harland 1996). Harland \& Pudsey (1999) noted that within the sea ice limit the dinocyst assemblages were dominated by the heterotrophic form of protoperidiniod dinoflagellates with the presence of the autotrophic form of gonyaulacoid dinocysts prevalent outside the sea ice limit. There was a low dinocyst assemblage within the sea ice limit in comparison to assemblages in core-tops and traps outside the maximum sea ice limit (Harland \& Pudsey, 1999).

\subsubsection{Arctic studies}

Mudie (1992) studied dinocysts along transects across the Beaufort Sea estuarine environment, the Nansen Basin north of Barents Shelf, and ice shelf and pack ice environments on the Canadian polar margin and in the Canada Basin. Examples of 
areas studied by Mudie (1992) include Baffin Bay, Beaufort Sea and Barents Sea and they are discussed below.

Mudie (1992) found results for Baffin Bay included 9 dinocyst to 1 Acritarch Leiosphaeridia scrobiculata, and a strong positive correlation between Acritarch per cent abundance and sea ice cover which included an increase of Pterospermella and Acritarchs towards glacier meltwater. The gonyaulacoid to protoperidinioid (G:P) ratio in Baffin Bay decreased with lower summer temperatures and increasing latitude.

The results from Mudie (1992) for the Beaufort Sea sediments contained an average of 7 dinocyst species and Mudie found low numbers of Acritarchs (Halodiniuim majus, Leiosphaerida, Beringiella) and Chlorophytes. Brigantedinium and Leiosphareida scrobiculata dominate samples within the low salinity sedimentary plume off McKenzie River and Sigmopollis are common. Mudie (1992) suggested that gonyaulacoid dominate the pack ice margin in deeper waters with the G:P ratio increasing from 0.5 to 1.5 and overall in the Beaufort Sea there is a low diversity of Acritarchs and Dinoflagellates.

Mudie (1992) found that results for Barents Sea showed the sediments contained one sample with up to $25 \%$ of protroperidiniods. Marginal ice zones had G:P ratios ranging from 0.8-1.8 (mean 1.4) and pack ice G:P ratios were 0.3-1.0 (mean 0.6). Mudie (1992) found a correlation for small acritarchs found in abundance and highly stratified water column overlain by a low salinity layer. Other areas of the Canadian Polar Margin and Central Artic Ocean show a G:P ratio 0-1.0 (mean 0.5) with gonyaulacoid cysts rare or absent.

Rochon, Turon, Matthiessen and Head (1999) studied the distribution of recent dinoflagellate cysts in surface sediments throughout the North Atlantic Ocean and adjacent seas. The dinocyst distributions have a low to moderately high species diversity that varies from between 2-18 taxa. Results from continental margins of the North Atlantic Oceans and adjacent seas have high abundances in surface sediments of 100 to $1,000 \mathrm{cysts} / \mathrm{cm}^{2}$ yr. The results from the Central North Atlantic and Baffin Bay have moderately low surface sediment cyst concentrations in the 
order of $0.1-1 \mathrm{cysts} / \mathrm{cm}^{2}$ yr. Taxa with morphological similarities were grouped together and the four most abundant (50-100\%) of the total were Operculodinium centrocarpum, Nematosphaeropsis labyrinthus, Pentapharsodinium dalei and Brigantedinium spp. A further 10 taxa were common (10-50\%) and 13 taxa were considered rare (0-10\%) (Rochon et al. 1999). 


\section{CHAPTER 2 \\ PRYDZ BAY MARINE ENVIRONMENT}

\subsection{Circulation in Prydz Bay}

Circulation in Prydz Bay appears to be dominated by a clockwise rotating gyre (fig 2.1) which is situated approximately between $66.5^{\circ} \mathrm{S}-68^{\circ} \mathrm{S}$ (Wong et al. 1998). Within Prydz Bay a cold, less saline coastal current enters the bay from the east flowing westward along the shelf break. In the centre of the bay near the Amery Ice Shelf this water partly joins the gyre. The rest of the coastal current continues to flow westward beneath the eastern side of the Amery Ice Shelf, flowing out the west side as colder Ice Shelf Water. Part of this current joins the northward flowing arm of the gyre to either recirculate back into the bay or join the flow westward with the Antarctic Coastal Current (O’Brien et al. 1991; Wong et al. 1998).

The Antarctic Divergence acts as a barrier between the eastward flowing Antarctic Circumpolar Current and the westward flowing coastal current and is inferred to be south of $63^{\circ} \mathrm{S}$ by Smith et al. (1994) and Nunes Vasz and Lennon (1996), which would place this area of upwelling within the ocean edge of the Prydz Bay Gyre. Nunes Vas and Lennon (1996) suggest that the gyre results in a deeper inflow of warmer upwelled Circumpolar Deep Water crossing the shelf break at about longitude $74^{\circ} \mathrm{E}$ resulting in the transport of nutrient rich water into Prydz Bay.

\subsection{Water masses in Prydz Bay}

Within Prydz Bay, Summer Surface Water occurs only in summer at the top of the water column and has temperatures between $-1.8^{\circ} \mathrm{C}$ to $2.1^{\circ} \mathrm{C}$ and a lowered salinity of 30.6-34.2. The Summer Surface Water column extends from the surface to $80 \mathrm{~m}$ off the continental shelf thinning to 40-50 m within Prydz Bay (Nunes Vas and Lennon, 1996; Wong et al. 1998). The freshness of the Summer Surface Water is due to the melting of sea ice during the summer. Higher Summer Surface Water temperatures are found in the south western half of Prydz Bay just north of the Amery Ice Shelf. Wong et al. (1998) suggest that this is due to thinner sea ice cover in that area which melts earlier in the season allowing the Summer Surface Water to 


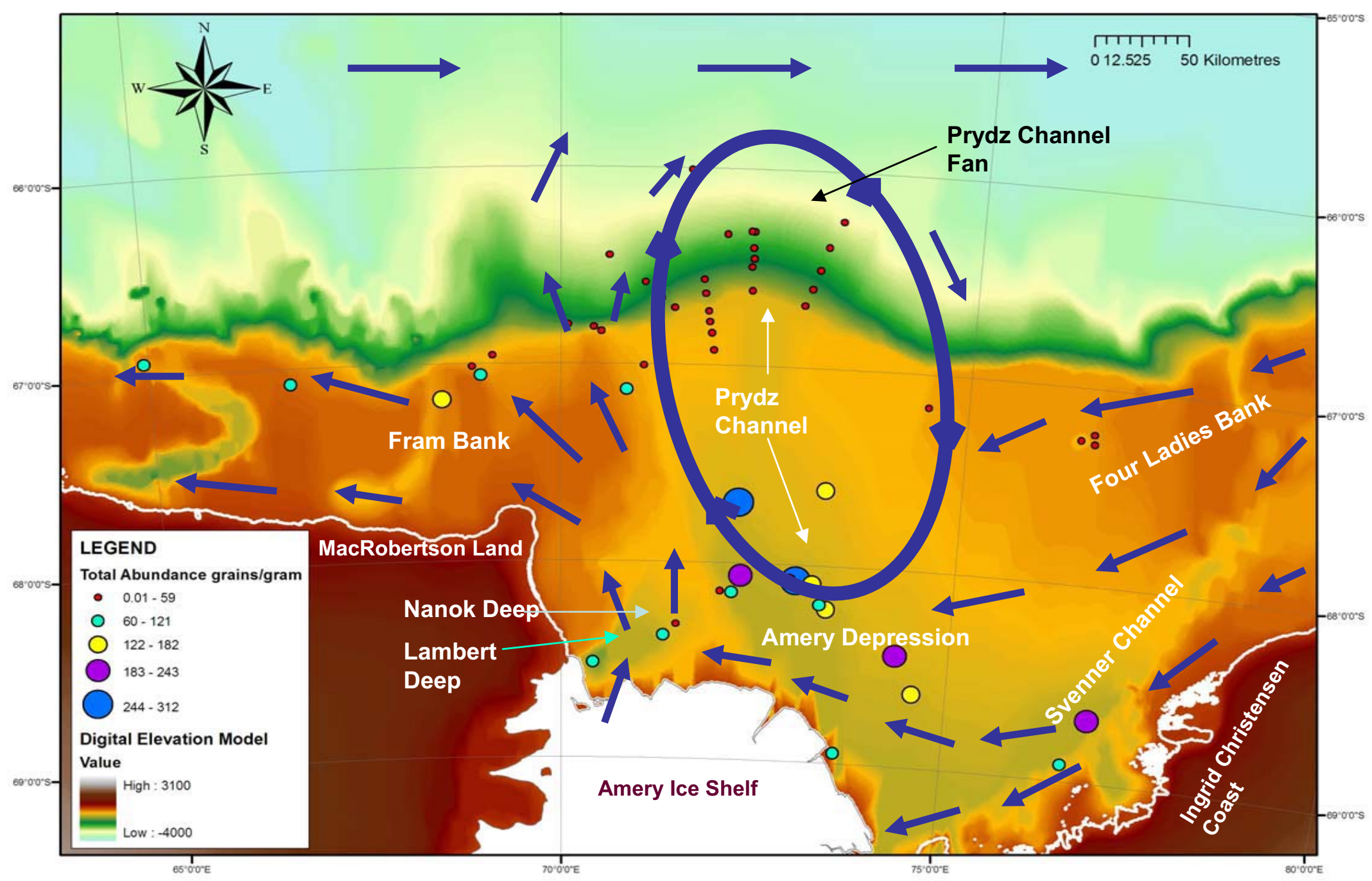

Fig. 2.1: The Prdyz Bay gyre represented by the blue circle, circulates clockwise and dominates the water currents represented by the blue arrows. The coastal current enters the bay from the east flowing westward along the shelf break till it joins the gyre in the centre of the bay. The rest of the current follows the coast line and flows beneath the Amery Ice Shelf in the east and exits from the western side before continuing westward along the coast or heads north west to join the gyre and recirculate back into the bay. Also shown are the sample points for palynomorphs with highest abundances as larger circles as per legend. Adapted from Wong et al. 1998. 
be heated from solar radiation sooner than elsewhere in the embayment (Smith et al. 1984, Smith \& Treguer, 1994, Wong et al. 1998).

Below the Summer Surface Water is a layer of so called Winter Water, a remnant of surface water formed in winter. Winter Water temperatures are colder between $-1.9^{\circ} \mathrm{C}$ to $-1.5^{\circ} \mathrm{C}$ and Winter Waters have a higher salinity (34.2-34.5) than Summer Surface Water. Below the Summer Surface Water in the ocean domain, the thickness of the layer of Winter Water is $30 \mathrm{~m}$, increasing to $200-300 \mathrm{~m}$ on the continental shelf (Nunes Vas and Lennon, 1996, Wong et al. 1998). The main depressions within Prydz Bay all contain highly saline water below the Winter Water layer and are called Low Salinity Shelf Water (34.5) which lies above the highly saline Antarctic Bottom Water (34.7). Low Salinity Shelf Water is formed by salt rejected from winter sea ice which sinks to become trapped and accumulate in deeper areas such as the Amery Depression. Low Salinity Shelf Water is also formed by the on shelf mixing of Circumpolar Deep Water that has cooled during the winter (Wong et al. 1998).

Surface water masses over the shelf in Prydz Bay have been reported to exhibit anomalously high temperatures (Smith et al. 1984, Smith \& Treguer, 1994; Wong et al. 1998), but also contain a separate water mass of dense Ice Shelf Water found at intermediate depths near the western side of the Amery Ice Shelf caused by the outflow of the current from beneath the Amery Ice shelf (Fricker et al. 2001). There is a differing of opinion as to whether Antarctic Bottom Water formation occurs within the bay and Smith and Treguer (1994) suggest that there is no evidence to support Prydz Bay continental shelf water being directly involved with bottom water formation. Wong et al. (1998) on the other hand think that there is every possibility that high salinity bottom water could have been formed locally in the Prydz Bay region. O'Brien et al. (2001) suggest that in contrast to the Ross and Weddell Sea basins, Prydz Bay produces only a small volume of high salinity deep water due to its geography and bathymetry, in a limited contribution to current activity beyond the shelf. 


\subsection{Circulation beneath the Amery Ice Shelf}

The recognition of marine sediments in cores from beneath the Amery Ice Shelf provides evidence for landward transport due to current activity (Hemer \& Harris, 2004). Marine sediments from beneath the ice shelf do have a slower rate of deposition than sediment from open water immediately in front of the ice shelf. This calls into question past researchers defining open water conditions as soon as marine sediments are recognised in the sedimentary record. It is likely that a floating ice sheet may have marine sediments transported beneath the ice sheet but it would clearly not represent open water conditions (Hemer \& Harris, 2004).

Circulation beneath the Amery Ice Shelf is predominantly horizontal and driven by the density gradient in the cavity beneath the ice shelf. Circulation is formed by melting and freezing processes combined with the horizontal exchange of heat and salt across the open ocean boundary at the ice front (Williams, 2001). At the Lambert Glacier grounding point $\sim 2,500 \mathrm{~m}$ below sea level at $73.2^{\circ} \mathrm{S}$ (Allison, 2003), high pressure lowers the freezing point of the surrounding sea water to as low as $-3.4^{\circ} \mathrm{C}$ which is considered to be supercooled (Holland et al. 2001). Warmer incoming seawater from the westward flowing coastal current with a surface freezing point of about $-1.9^{\circ} \mathrm{C}$ melts the ice, some of which refreezes as marine ice (fig 2.2). This seawater mixes with melt water along the grounding line and in doing so decreases the density and salinity of the melt water. The mixed water mass is referred to as Ice Shelf Water which rises along the base of the ice shelf. As the Ice Shelf Water rises it will eventually reach a point where its temperature becomes lower than the local freezing point and will adhere to the underside of the ice shelf as marine ice. The Ice Shelf Water then flows in a seaward direction on the west side of the Amery Ice Shelf (Fricker et al. 2001, Allison, 2003, Williams et al. 2001, Church et al. 2002, Holland et al. 2001).

The landward and seaward flows at the Amery Ice Shelf are laterally separated due to deflection to the left by the Coriolis force combined with the westward flowing Coastal Current (Harris, 2000). This flow pattern should result in sediments on the eastern shelf being higher in marine deposits and those on the western shelf higher in 


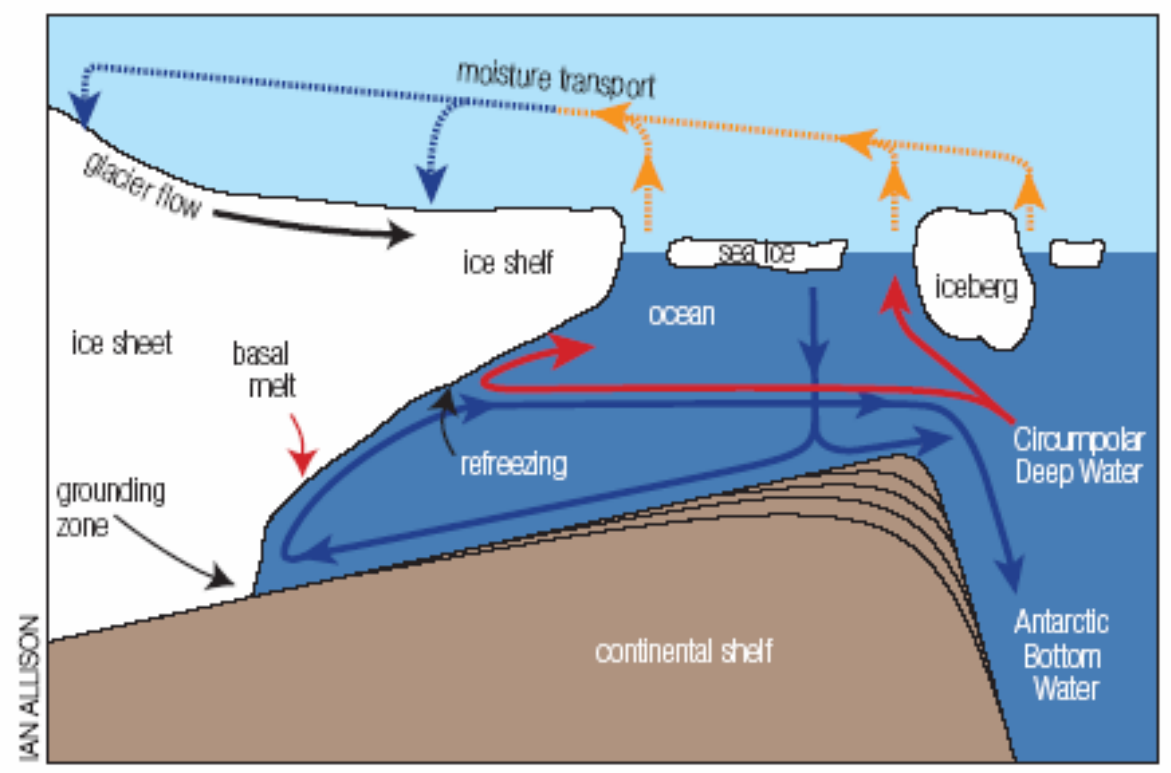

Fig. 2.2: Circulation beneath the Amery Ice Shelf depicting warmer Circumpolar Deep Water under the ice shelf circulating and freezing as marine ice or mixing with melt water and flowing out as Ice Shelf Water. Freezing of marine ice creates more saline waters which sink and flow out as deeper shelf waters (Church et al. 2002).

terriginous deposits. Harris (2000) found this to be the case with sediments deposited in front of the Vanderford Glacier, Antarctica.

\subsection{Sea Ice inhabitants}

Sea ice habitats are characterized by steep gradients in temperature, salinity, light and nutrient concentration (Arrigo, 2003, Arrigo et al. 2004). Blooms that occur over the spring and summer leave microbial populations surviving in the surface waters at the beginning of ice formation in the autumn. As the newly formed ice spreads over the surface, micro algae, bacteria and heterotrophic protists which include flagellates, ciliates and amoebae, may be scavenged from the water column. Columnar ice extends down into the water column as more ice is formed, and brine filled channels may form brine pockets in the ice where diatoms and algal communities may flourish, provided they have access to nutrients (Arrigo, 2003, Arrigo et al. 2004, Lizotte, 2003). Among the sea ice communities, photosynthetic protists are the dominant autotrophs and these include diatoms, dinoflagellates, prymnesiophytes, prasinophytes, chryosphytes, cryptophytes, chlorophytes, euglenophytes and a photosynthetic ciliate (Lizotte, 2003). 
Upper sea ice communities survive at or near the sea ice surface (fig 2.3) and are dominated by small photosynthetic dinoflagellates, chrysophytes and prasinophytes. Due to lower temperatures and hypersaline conditions, growth of diatoms and other plankton may be limited in the upper sea ice in the winter and early spring. Although the upper sea ice community often has adequate light available for growth, it may be restricted in available nutrients (Arrigo, 2003). It is regions with ice floes that are linked with the underlying sea water where the sea ice algae will flourish due to accessible nutrients (Arrigo et al. 2004).

Temperatures of surface ice in McMurdo Sound, Antarctica are often lower than $-20^{\circ} \mathrm{C}$, but at the base, the ice is close to seawater temperature. Internal sea ice communities (fig 2.3) are found at levels where sea water can infiltrate the ice floe and this may be due to snowfall loading which pushes the ice further into the sea (Arrigo, 2003, Arrigo et al. 2004). Ice rafting caused by wind and tide movement resulting in the flooding of the ice surface with sea water can also occur. Microbial communities within the ice rely on nutrients seeded by particles scavenged during ice formation. Bottom ice communities form in the skeletal layer, a highly porous layer that forms at the lower margin of growing columnar ice (fig 2.3), and they extend upwards as far as $0.2 \mathrm{~m}$ where conditions are environmentally stable (Arrigo, 2003, Arrigo et al. 2004). Platelet ice is found beneath landfast ice adjacent to floating ice shelves where it becomes super cooled and is the most porous of sea ice. It has five times more surface area for algal attachment and because of its high surface area and high porosity it contains a high accumulation of sea ice algae (Arrigo et al. 2004).

The seasonal ice coverage in the Southern Ocean produces a different timing and distribution of sea ice algae to that of phytoplankton in the water column (Lizotte, 2001). Cyst formation is an overwintering adaptation in the upper sea ice used for survival in the harsh conditions. Some species are able to overwinter as statocysts and begin growth early for dispersal in the water column in summer and fall. The exchange of organisms between the sea ice and water column in this way provides an important environment for natural selection of microalgae for seeding phytoplankton blooms in marginal ice zones (Lizotte, 2001; Stoecker et al. 1998). They provide a source of food for higher organisms when nutrients within the water column may be low (Lizotte, 2001). 
Summer sea ice melting in the Southern Ocean has an effect on the physical, chemical and biological oceanographic processes (Leventer, 2003). Polar productivity for interglacial periods (fig 2.4) in the form of phytoplankton blooms makes up $\sim 50 \%$ of the annual primary production in the Southern Ocean. The release from the sea ice and subsequent blooms seeds ice edge communities and supports the pelagic community by ensuring a source food in the form of sea ice algae both in the winter and during the late spring through to summer. 
a.

Pack Ice

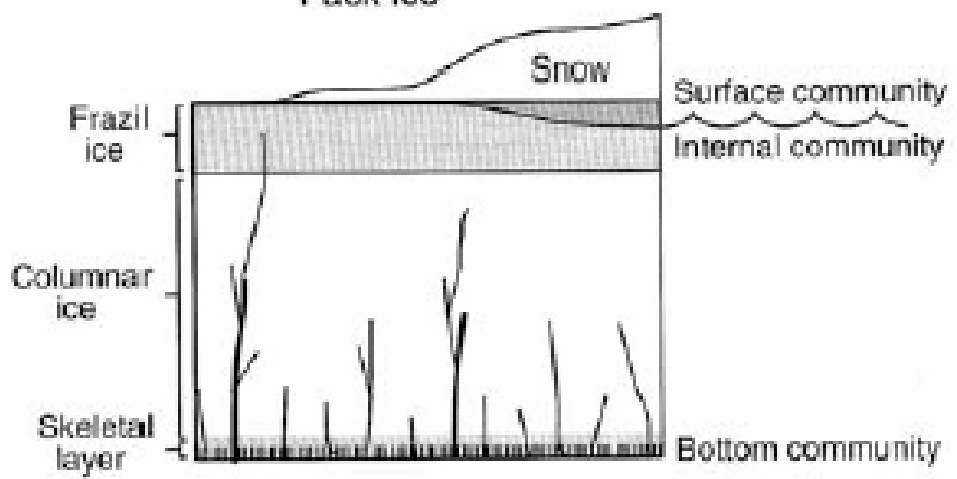

b.

Land-fast lce

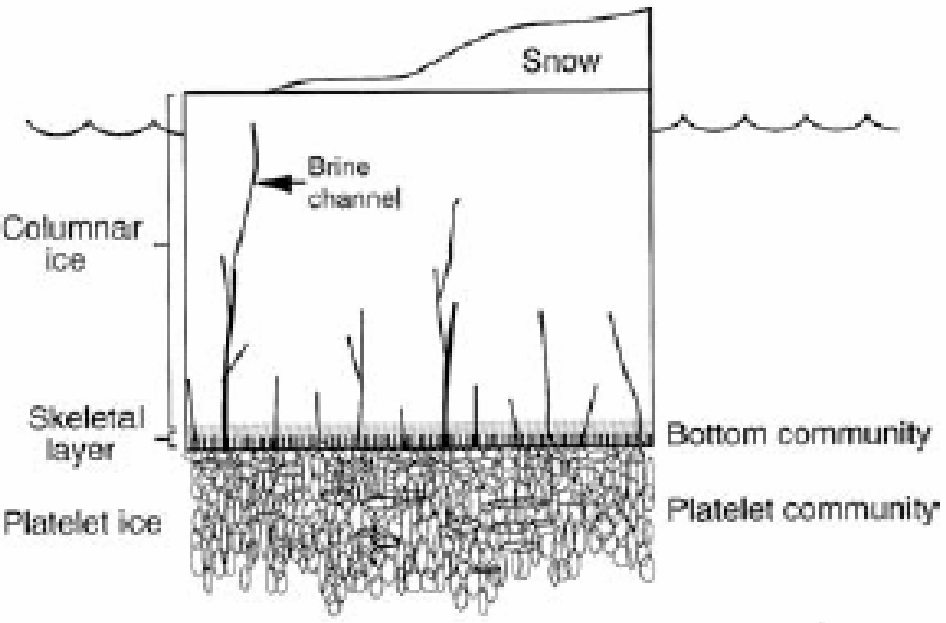

Fig. 2.3: Pack ice and land fast ice showing the major physical features and locations of microbial habitats of surface, internal bottom and platelet communities (Arrigo \& Thomas, 2004). 

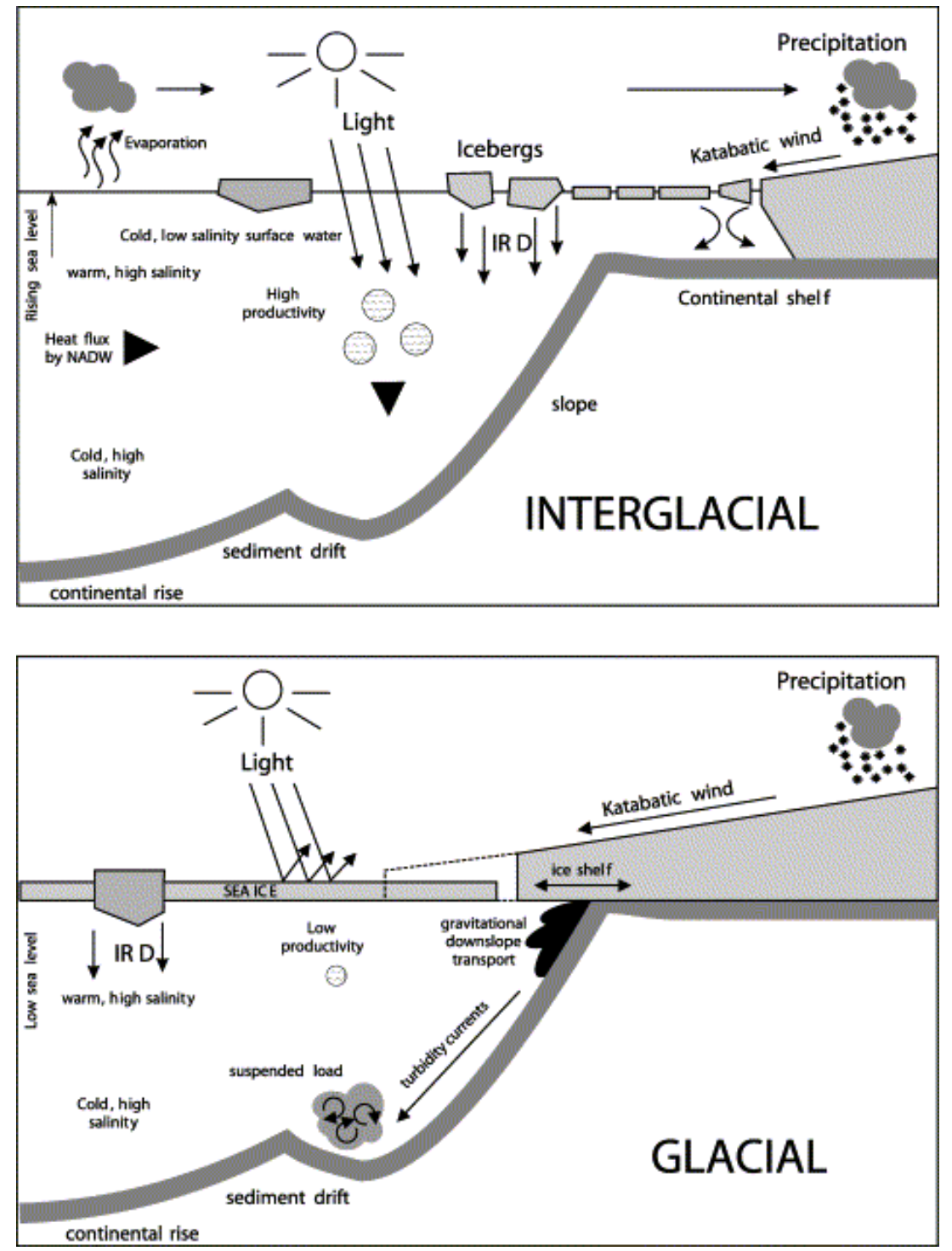

Fig 2.4. Model for the environmental conditions triggering palaeoproductivity during glacial and interglacial intervals, in the continental margin of the Antarctic Peninsula (Villa, et al. 2003) 


\section{CHAPTER 3 \\ METHODS AND RESULTS - PALYNOLOGY}

\subsection{Introduction}

Fifty eight samples of surface sediments were collected by the Australian Geological Survey Organization from gravity cores (GC) taken in Prydz Bay during three cruises at intervals of 2 years from 1993. The gravity cores are held by Geoscience Australia in Canberra where they are kept in cool storage. Gravity coring requires a weighted corer to be dropped into the ocean where it sinks into the sediments with the assistance of its weight (O'Brien et al. 1993). The surface sediments are usually disturbed as the corer hits the sea floor. Therefore the sediments used in this study are actually from just below the sediment/water interface. Each core was cut into lengths of approximately one metre and wrapped in sheets of plastic to keep in the moisture. The sediments were collected from depths of approximately $0-2 \mathrm{~cm}$ below sea floor (cbsf) of each core. In some cases where sediment had previously been removed, samples were from as deep as 5 cbsf. All samples were placed in air tight jars and labelled. The samples were transported to Victoria University, Wellington, for palynological processing and grain size analysis.

For each cruise the sample numbers and drill positions were as follows:

1993: GC901 - 19 samples (15 on the shelf, 4 on the fan)

1995: GC149 - 22 samples (6 on the shelf, 16 on the fan)

1997: GC186 - 17 samples (14 on the shelf, 3 on the fan)

Information on the latitude, longitude and the water depth for each sample are included in Appendix A. Each sample was given a preliminary sediment description and approximate grain size determined (Appendix B), and then placed in a beaker and put in an oven overnight to dry out. The dry weight was recorded (Appendix B) and approximately 5 grams per sample was separated out to be used for palynology processing while the remaining sediment was used for grain size analysis. Four samples from the Mid Shelf area did not contain sufficient sediment after the drying 
process for completion of grain size analysis, (GC901-24, GC901-25, GC901-26, GC186-13) and this was due to their content being of very fine silt, which had a very light dry weight.

\subsection{Palynological processing}

Processing procedure followed standard palynology techniques but without any oxidation and sieving in order to retrieve as many marine palynomorphs as possible. Hydrochloride acid $(\mathrm{HCl})$ was added to each beaker to dissolve carbonates, stirred, and left to settle and any reaction was noted (Appendix B). The process was repeated until all reaction had ceased which in some cases was 1 or 2 days. The beakers were topped up with filtered water, stirred thoroughly and left for about an hour to settle, then decanted. In order to dissolve silicates Hydrofluoric Acid (HF) was poured into each beaker covering the sediments. The samples were then stirred and left for approximately 36 hours with intermittent stirring during that time.

Filtered water was added and each sample was left to settle before decanting into a mixture of bicarbonate of soda and filtered water in order to neutralize the HF. Care was taken during decanting because of the reaction (fizzing) that took place in the neutralising tank. After each beaker was decanted into the soda and water mixture, it was topped up with filtered water, stirred and left to settle for about an hour. This process was repeated until all reaction in the neutralising tank had ceased; in most cases this meant about 3 to 4 washes.

The samples were then transferred into test tubes, agitated and topped up with filtered water, then centrifuged at 2,600 rpm for 5 minutes. This process was repeated, and then a small amount of $\mathrm{HCl}$ was added to the samples to help with disaggregation and to remove soluble fluorides. The samples were washed with filtered water a further 3 times. After the final wash, about $30 \mathrm{ml}$ of Sodium Polytungstate with an sg of 1.8 was added, the sample centrifuged at 1,800 rpm for 15 minutes, and left for a few hours. A pipette was used to extract the floating residue (float $\mathrm{A}$ ) which was put into a test tube with a little $\mathrm{HCl}$ added to stop its organic matter clumping, topped with water, agitated then centrifuged at 3,000 rpm for 3 minutes. This washing process was repeated 6 times. 
Slides were preheated and a small drop of residue from each sample was placed in the centre and mixed with glycerine jelly, then a cover slip was placed on top of the slide, labelled and left overnight to dry. This process was repeated by agitating and then centrifuging the Sodium Polytungstate leaving it to settle again and obtaining a second float (float B). This second float provided an assurance that maximum numbers of palynomorphs had been recovered. Six slides from each sample were prepared, three from each float.

\subsubsection{Microscope and camera technique}

A light microscope Leica DML was mounted with a Leica DFC camera for image acquisition. Slides were analysed at x20, x40 or x100 magnification. The colour photographs were later printed out and stored in a catalogue for quick reference. Problems encountered with photography were the position of some of the palynomorphs on the slides, for example if they were half hidden by amorphous material or charcoal, or if they were breaking up or dissolving.

\subsubsection{Counting method}

All slides were scanned for content before counting and a qualitative record of species was made. The three slides from each sample that were chosen for the count did not always involve both A and B floats due to some samples having very low palynomorph content which was mostly recovered in the first three slides from the initial float A. Slides were scanned from left to right and all palynomorphs were counted, photographed and coordinated using an England finder. Some slides contained a lot of pollen which was often broken and obscured by charcoal pieces. Individual pollen and spores were only counted if more than half of the pollen grain was recognisable.

All data were entered on a separate Excel worksheet for each sample number. Data collected show the type and count of each palynomorph and the latitude and longitude, bathymetry, lithology and total count for the sample. Data from excel worksheets were transferred on to the master spreadsheet (Appendix A) and colour coded with red signifying any count $<20$, black $\geq 20$, green $\geq 100$ and blue $\geq 1,000$. 
Each category in each sample was subtotalled and each sample totalled, then a final palynomorph subtotal and total was given.

\subsubsection{Grains per gram}

Grains per gram were calculated using the amount of dry weight of sediment used in the palynomorph processing (Appendix B) which was divided by the total number of palynomorphs counted in each sample and multiplied by a factor of 1.5 (grains/ palynomorph x1.5). Based on an initial count, the slides with the highest number of palynomorphs were selected from the 6 slides made up as mentioned above. It was estimated from the initial count that approximately two thirds of the palynomorphs had been captured in those 3 slides, therefore to determine the total number of palynomorphs required multiplying by 1.5 .

\subsubsection{Contamination}

Three or four slides contained modern bisaccate pollen. These were easily identified as a contaminant due to their fresh appearance and excellent preservation. Another source of contamination were plastic filings found in some samples which were believed to have come from the PVC inner linings of the drill cores that were cut into meter long lengths for storage purposes.

\subsubsection{Oxidation}

Oxidation was carried out on 4 samples that had been processed as above (901/23, 901/25, 901/33 and 186/16) and the results were compared with non processed samples. The process removes unwanted material and concentrates the palynomorphs. The method used $30 \mathrm{ml}$ of Nitric Acid (HNO3) combined with $15 \mathrm{ml}$ of saturated Potassium Chloride $(\mathrm{KCl})$ which was poured over the sample residues and left for 10 minutes. The samples were then topped up with filtered water, centrifuged and rinsed twice and a small amount of Ammonia $\left(\mathrm{NH}_{3}\right)$ was added followed by further rinsing. Slides were prepared from the residue and checked for content. 


\subsection{RESULTS - PALYNOLOGY}

\subsubsection{Introduction}

The 58 samples processed yielded a total of 12,727 palynomorphs. All counts are listed on the master spreadsheet (Appendix A).

$\begin{array}{ll}8 \text { samples } & 0 \text { to } 20 \text { palynomorphs (includes } 1 \text { nil sample) } \\ 14 \text { samples } & 21 \text { to } 99 \\ 35 \text { samples } & 100 \text { to } 999 \text { “ } \\ 1 \text { sample } & \text { over } 1,000\end{array}$

The assemblages of palynomorphs recognised in Prydz Bay have been grouped into two broad categories: Holocene and reworked palynomorphs (Appendix A). The Holocene palynomorph groups were further subdivided and their assemblages are described below, followed by reworked palynomorphs assemblages.

\subsection{Acritarchs}

Acritarchs are a polyphyletic group which may include ancestors from both chromophytes and chlorophytes (Strother, 1996). Acritarchs can be found in large numbers and have high taxonomic diversity. They may represent a variety of life stages for eggs, cysts and mature tests, which in turn may represent a higher organism of plant or animal. They are best defined as representing the encystment phase of an unknown algal life cycle (Strother, 1996) and may be regarded as a form of phytoplankton that is either extinct or still living in the water column today (Tappan, 1980). The wall composition of acritarchs is composed of a fatty acid similar to plants, called sporopollenin, which enables the cyst to survive diagenesis (Brasier, 1980, Tappan, 1980, Strother, 1996). This also will enable them to survive adverse environmental conditions over time, for example in the colder Polar Regions. They may contain a wall structured with single or multiple layers surrounding a central cavity which may be closed or open to the exterior by varied means. The shape, structure, and ornamentation may vary; for example a homomorphic cyst will have similar processes and a heteromorphic cyst will have a significant variation of process size and/or shape (Strother, 1996). The types of acritarchs identified during 
this study are Acanthomorphitae, Leiosphaerida, Sigmopollis and Sphaeoromorphs and these are described below.

\subsubsection{Acanthomorphitae}

Acanthomorphs are spherical or ellipsoidal with no inner body or surficial crests. Their topography may be elaborate with processes that have a regular or arbitrary distribution and some may have excystment structures (Strother, 1996). They are represented by Acritarch spp. 1 - 4 (Plate 1) and show variation in morphology with species 2 and 4 being heteromorphic while species 1 and 3 are homomorphic.

Species 4 has an excystment opening consisting of a median split (Plate 2 nos. 1-2).

\subsubsection{Leiosphaeridia}

Leiosphaeridia are spherical to ovoid, may have slight ornamentation and are without processes but may exhibit a pylome. They have a thin cell wall and may be light brown to pale yellow or colourless (Plate 2 no. 5). They are difficult to classify due to the lack of taxonomically significant features (Lindgren, 1981).

\subsubsection{Sigmopollis}

Sigmopollis are subspherical to ovoid in shape and the excystment structure is a sigmoidal suture around the periphery. They may have a prominent tab with matching notch on opposite margins of the aperture. The wall is smooth and unornamented, hyaline and colourless (Strother, 1996).

\subsubsection{Sphaeoromorphs}

Sphaeoromorphs are morphologically simple palynomorphs with a basic spherical shape and cover a wide range of sizes (Plate 2 nos. 6-12).

\subsection{Dinoflagellate cysts}

Dinoflagellates are a diverse group of unicellular algae and an important part of phytoplankton. Thick walled resting cysts are often produced during a stage in the life cycle of a dinoflagellate and may or may not resemble the living motile cell. In adverse environmental conditions dinoflagellates can also produce temporary cysts (Brasier, 1980, Fensome et al. 1996). Identification of dinocysts may rely on thecal 
plates found on armoured motile cells or in the case of athecate or unarmoured cysts other features may be used for identification. The cell walls are made up of dinosporin, a complex organic compound that is very resistant to dissolution (Brasier, 1980, Tappan, 1980, Fensome, et al. 1996, Armand \& Leventer, 2003).

In Antarctic waters dinoflagellate assemblages are of low abundance which is in contrast to temperate and warmer tropical seas (McMinn \& Scott, 2005). Most Quaternary dinoflagellates belong to the Orders Gymnodiniales and Peridiniales. The largest group of living dinoflagellates from the Peridiniales are the Family Protoperidiniaceae (Mudie \& Harland, 1996) from which Protoperidinium is the most diverse dinoflagellate genus in Antarctic waters and many species are endemic to the Southern Ocean and Antarctica (McMinn \& Scott 2005). Nearly all the Protoperidinium spp. are heterotrophic and produce resting cysts which have brown walls, intercalary archeopyles and a simple morphology with little ornamentation. Protoperidinium spp. can exist in conditions of reduced light and mixed salinity, and are usually abundant in areas of upwelling (Mudie \& Harland, 1996). The major Holocene dinoflagellate species are discussed below followed by other minor Holocene dinoflagellate species.

\subsubsection{Selenopemphix antarctica}

Selenopemphix antarctica is spherical with two antapical horns and is apically to antapically compressed (Plate 5 nos. 1-4). Cysts are slightly pinkish in colour with granulations on the surface but no other ornamentation is present. This species has been exclusively recorded in the Southern Hemisphere and is endemic to the Southern Ocean and Antarctica. Selenopemphix antarctica dominates assemblages south of the Antarctic Polar Front close to the Antarctic continent especially in areas seasonally covered with sea ice (Marret \& de Vernal, 1997).

\subsubsection{Protoperidinium sp. 2}

Protoperidinium sp. 2 are dark brown in colour with a granular surface with no tabulation or processes present. They are sub-spheroidal to ovoid in shape with a prominent cingulum and sulcus (Plate 4 nos. 10-12). This species was first recorded 
as a Quaternary Protoperidinioid in situ dinocyst from the Cape Roberts Project-1 core unit 3.1 at $32.77 \mathrm{~m}$ below the sea floor in the Ross Sea (Wrenn et al. 1998).

\subsubsection{Cryodinium sp.}

Cryodinium sp. is a spherical protoperidinioid cyst with a smooth to granular surface and dark brown in colour. The cyst shows paratabulation and an intercalary archeopyle (Plate 3 nos. 4-12). It is a new endemic form recorded between the Antarctic Polar Front and the ACC-Weddell Gyre Boundary by Esper \& Zonneveld (2002) and is a new record to the Antarctic Coastal Current and Prydz Bay environment.

\subsubsection{Other dinocysts}

The dinocyst Alisocysta sp. is ovoid with penitabular septa with an apical archeopyle and pale brown in colour (Plate 3 nos. 1-3). Impagidinium sp. (Plate 4 nos. 6-9) is a subspherical light brown dinocyst with a smooth wall and paratabulation.

Impagidinium dinocysts are usually found in deeper oceanic environments (Dale, 1996). Hystrichosphaeridium sp. (Plate 4 nos. 4-5) is spherical with chorate processes that vary in length. Protoperidinium sp. 1 (Plate 5 nos 5-9) is spherical to ovoid in shape with suessioid tabulation type, pale yellow and no processes. Dinocyst sp (Plate 4 nos. 1-3) is ovoid with an apical archeopyle and chorate processes and cannot be referred to any existing genera.

\subsection{Prasinophycean algae}

The Prasinophyte group can be defined as noncellulosic green algae with scaly flagella arising from within an apical pit (Tappan, 1980). The diagnostic characters of this group are a two phase life history and the presence of scales on the motile cell body that differ to those on the flagella. In Arctic waters they are reported to be associated with water-column features of low temperature, enhanced productivity and stratified water columns with low salinity surface water overlying low oxygen bottom waters (Mudie, 1992, Mudie \& Harland, 1996). The prasinophytes types recovered in this study are two species of Cymatiosphaera, Tasmanites sp. and Pterospermella sp. The Tasmanites sp. were fresh looking and light grey unlike similar species found in ancient sediments which are usually brown. 


\subsubsection{Cymatiosphaera sp. 1 and sp. 2}

The Cymatiosphaera characteristically have surface crests making it hard to discern any openings and are most abundant in Arctic waters in upwelling or nutrient rich waters containing normal to low salinity (Mudie \& Harland, 1996). They have a spherical central body which may be colourless to pale yellow or light brown and have no processes but surface ornamentation consists of a fine crest which anastomoses over the surface. The difference between these species is their size with species 1 being 15-20 $\mu \mathrm{m}$ in diameter (Plate 5 nos. 10-12) and species 2 much larger, with a diameter of 75-115 $\mu \mathrm{m}$ (Plate 6 nos. 1-10). Specimens similar to Cymatiosphaera sp. 2 have been recovered from the lower Miocene with two occurrences in the Quaternary section of the Cape Roberts Project-1 (CRP-1) $20.04 \mathrm{~m}$ below sea floor, McMurdo Sound (Hannah et al. 1998).

\subsubsection{Tasmanites and Pterospermella}

Species assignable to Tasmanites (Plate 7 nos. 1-3) change morphology throughout their life cycle. In their early life history the wall is single layered and develops with growth to a double layered wall. They have perforations of radially arranged pores of two distinct sizes. Pterospermella (Plate 6 nos. 11-12) are compressed and have no surface crests but are bordered by a wide floatation membrane and though mostly found in oceanic regions are also found in lowered salinity Polar Regions (Mudie \& Harland, 1996). Tasmanites along with Pterospermella are regarded as the two fossil genera that are indisputably prasinophytes (Guy-Ohlson, 1996).

\subsection{Red algae}

One species of red algae (Beringiella sp.) has been identified in this study. This species has not been documented in the Southern Ocean before, but is known to occur in the deltaic and tidewater glacier environment of the Beaufort Sea and Baffin Island in the North Atlantic and at ice margins and arctic estuaries where there is a lowered salinity of $<32 \%$ in the northern hemisphere (Mudie \& Harland, 1996). Individuals are similar to the red alga Beringiella fritilla which is found only in upper Pleistocene sediments of the eastern Bering Sea in the Arctic (Mudie, 1992). They have an ovoid central body with smooth walls with the edge $\sim 1 \mu \mathrm{m}$, and are brown with an apical archeopyle with serrated edges (Plate 7 nos. 4-11). 


\subsection{Unknowns}

The unknowns consist of marine palynomorphs that cannot be referred to any existing genera. Some are shown on Plate 10 nos. 10-12, Plate 11 nos. 1-3, 6, 9-11 and Plate 12 nos. 11-12. For descriptions see Appendix C.

\subsection{Zooplankton}

Zooplankton recovered in Prydz Bay consist of Tintinnid loricae and their flask shaped cysts and a species that has not yet been identified.

\subsubsection{Tintinnids}

The Tintinnid loricae are known to inhabit the Antarctic waters in numbers which are exceeded only by the diatoms that they feed on (Brazier, 1980). Loricae size may be from $20-1,000 \mu \mathrm{m}$ in length but most are $120-200 \mu \mathrm{m}$ with a variety of shapes from globular to conical and bell shape. They have an aperture at the oral end and most are closed at the aboral end with either a rounded or pointed form (Plate 8 nos. 5-6). The tintinned ciliate cell, which doesn't survive processing, is attached to the loricae by a pedical (Brasier, 1980). Tintinnid cysts recovered in this study are ovoid, brown and thin walled which can be easily folded and they have an aperture that extends out from the central body (Plate 8 nos. 3-4). The taxonomic subdivision of Tintinnids is uncertain due to many of their species generations showing infraspecific variability (Petz, 2005).

\subsubsection{Zooplankton sp.}

This species is spherical and two layered with an encysted inner body which is thick walled and brown in colour with no ornamentation but does contain a round aperture. The outer layer is thin and hyaline with a single "tail" attached, this layer folds easily (Plate 8 nos. 7-12 and Plate 9 nos. 1-9). The size can vary but averages between 125-175 $\mu \mathrm{m}$. This Zooplankton sp. is not yet identified.

\subsection{Foraminiferan linings}

Foraminiferan linings are the acid resistant inner linings of microforaminifera tests, and these organic remains can be up to $40 \%$ smaller than the host test. The linings 
can be found in numbers at shallow depths in most oceans and are usually found in greater numbers near upwelling, coarser sediment and higher salinity conditions but tend to decrease in numbers as water depth increases. Their morphology (Plate 7 no. 12 and Plate 8 nos. 1-2) may be uniserial, biserial or spiral and within the latter, linings may also be planispiral or trochospiral (Stancliffe, 1996).

\subsection{Insect parts}

Insect parts consist mainly of Scolecodonts, a combination of jaw and tooth fragments (Plate 11 no. 12). They are scattered throughout the samples and include other body casings that have been resistant to palynology processing.

\subsection{Egg cases}

There are a wide variety of egg cases within Prydz Bay surface sediments. The egg cases range in size from $\sim 75-300+\mu \mathrm{m}$ and can be a variety of shapes from ovoid, spherical to acentric and with or without ornamentation that may be elaborate and homomorphic or heteromorphic. Some examples are shown on Plate 11 nos. 4-5, 7-8 and Plate 12 nos. 1-10.

\subsection{Reworked palynomorphs}

\subsubsection{Reworked dinoflagellate cysts}

All reworked dinocysts in this study are part of the Transantarctic Flora that has been identified from previous work carried out on the dinoflagellate distribution of the Deep Sea Drilling Project (DSDP) (Kemp, 1975), MSSTS-1 drill hole McMurdo Sound (Truswell, 1986) and the CIROS-1 Drillhole (Hannah, 1997). Also included are Transantarctic Flora from CRP-1, (Hannah et al. 1998, Wrenn et al. 1998), the marine palynomorphs found in CRP-2/2A (Hannah et al. 2000), palynomorphs from CRP-3 (Hannah et al. 2001a) and Ocean Drilling Project sites in Prydz Bay 1165 (Hannah, 2005, McPhail \& Truswell, 2004a), 1167 and 1166 (McPhail \& Truswell, 2004b). The reworked dinocysts are Eocene in age and consist of Alterbidinium asymmetrica, Deflandrea spp. Enneadocysta partridgei, Spinidinium spp. Spinidinium macmurdoense, Turbiosphaera filosa, Vozzhennikovia spp. and operculae (see Appendix $\mathrm{C}$ for descriptions). Identification was hindered by the 
effects of reworking which often left most cysts in poor condition and not easily identifiable. Examples are provided on Plate 9 nos. 10-12 and Plate 10 nos. 1-9.

\subsubsection{Pollen}

The terrestrial material recovered in this study contains species of pollen and spores that range in age from the Permian to the Eocene (Raine pers. comm., 2005). They have been previously reported in MSSTS-1 drillhole McMurdo Sound (Truswell, 1986), in the CRP Ross Sea, Antarctica (Askin \& Raine, 2000) and from ODP cores in Prdyz Bay (Hannah, 2005, McPhail \& Truswell, 2004).

\subsection{Results for oxidised samples}

Samples that had previously produced large numbers of palynomorphs (901/23, $901 / 25,901 / 33$ and 186/16) were oxidised to try and concentrate the palynomorphs, remove unwanted debris and compare to fossil assemblages. The results show that the abundance of some species such as Zooplankton sp. Cymatiosphaera sp. 2, Beringiella sp. and two egg cases (Plate 10 nos. 10-12 and Plate 12 no. 1) were not generally altered in nearly all the samples oxidised. The only other palynomorphs sighted were two species of the dinocyst Selenopemphix antarctica but they had been affected by the oxidation and were very faded.

\subsection{Palynomorph distribution}

Counts of palynomorphs within each of the four geographical areas outlined in chapter one (fig 1.3) are presented in tables of total abundances, relative abundances and grains per gram of samples. Unless specifically mentioned each datum/value is given in grains per gram. Separate counts of Holocene and reworked palynomorphs, and counts of Holocene and reworked dinocysts are on the master spread sheet (Appendix A).

The count data are also represented in graphical form with absolute abundance for total Holocene palynomorphs shown in figure 3.1. Figure 3.2 shows the detailed components of the Holocene palynomorphs assemblage and figure 3.8 shows the Holocene dinocysts. Data for reworked assemblages are separated into reworked dinocysts in figure 3.9 and terrestrial palynomorphs in figure 3.10. The absolute 
abundance for total Holocene and total reworked palynomorphs is shown in figure 3.11 .

Maps of Prydz Bay have been compiled using Arcview and the position of the 58 sample sites plotted. Superimposed on this basic map are data for total Holocene assemblages (fig 3.1), a breakdown of the Holocene palynomorph assemblages (fig 3.2), Holocene dinocysts (fig 3.8), reworked dinocysts (fig 3.9), terrestrial palynomorphs (fig 3.10) and a further map showing absolute abundance for total Holocene and total reworked palynomorphs (fig 3.11). Four separate maps were compiled to show Zooplankton sp. (fig 3.3), foraminiferan linings (fig 3.4), red algae (fig 3.5) and Cymatiosphaera sp. 2 (fig 3.6). Maps for positions of all other palynomorphs were placed in Appendix D. A contour map showing salinity contours was also compiled (fig 3.7).

\subsection{Total Abundance for Holocene Palynomorphs}

Total abundances for Holocene palynomorphs (fig 3.1) show significant differences between the geographic areas. Within the embayment, the Holocene palynomorphs have the highest total counts in the Mid Shelf area followed closely by the Coastal areas. Abundance in the North Shelf for total Holocene is lower and palynomorphs become rare on the Fan.

Figure 3.2 indicates that although there seem to be no relative differences between the make up of the assemblages in each geographical area, notably there are higher counts of zooplankton and foraminifera linings and also higher counts of all other species in the Mid Shelf area. In the Coastal area there is a slight drop in numbers for zooplankton whereas the foraminiferan linings do not reduce in numbers significantly. On the North Shelf palynomorph numbers are reduced further, but foraminiferan linings now have a higher abundance than zooplankton which are now the second most common component. There is a very small proportion of Holocene species on the Fan. Comparison of total zooplankton and foraminiferan linings show that they are both represented in nearly all continental shelf samples and only concentrations within the geographic areas differ slightly. Approximately two thirds 

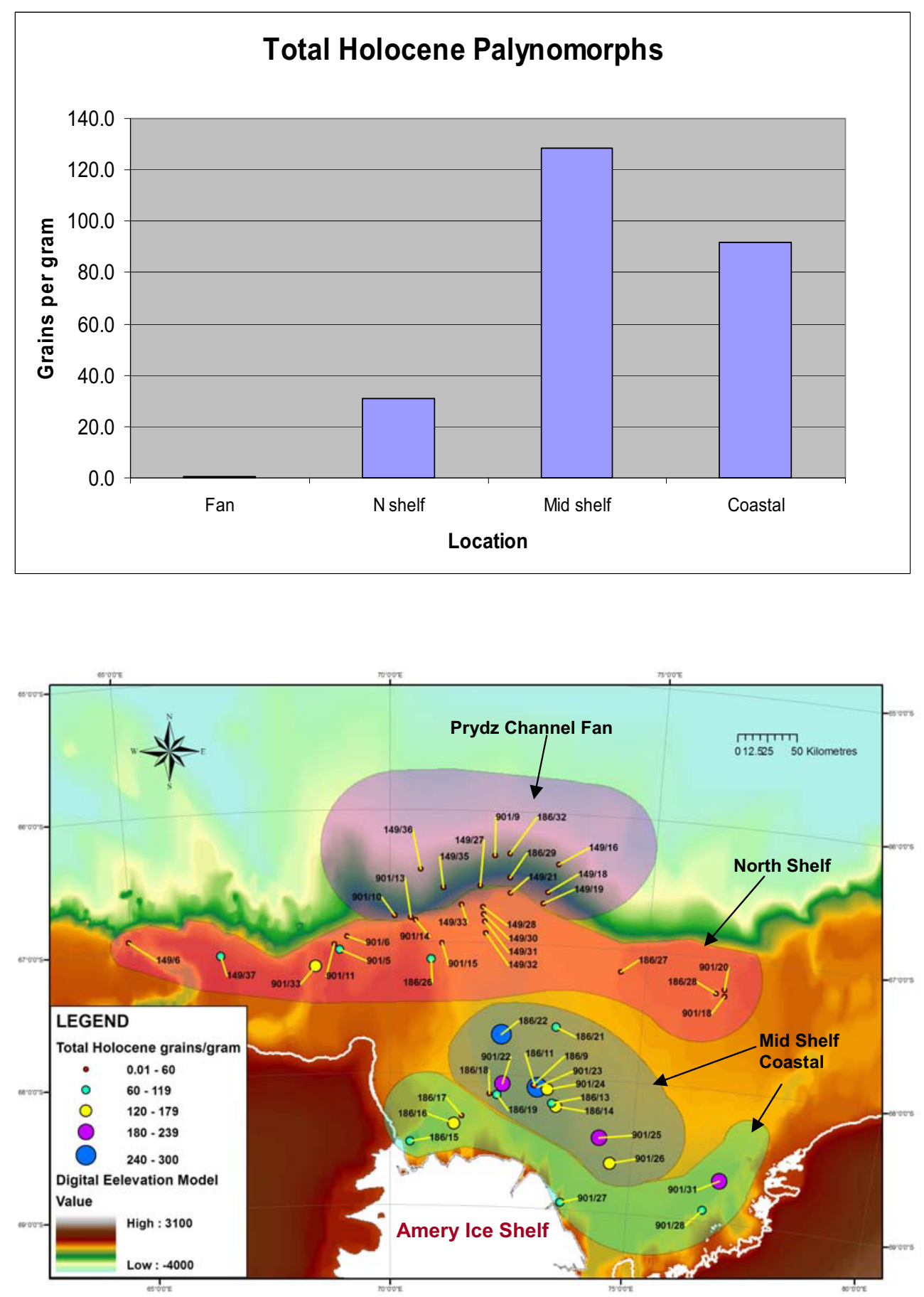

Fig. 3.1: Total Holocene palynomorphs grains per gram. Graph displays the geographical locations for total Holocene palynomorphs. The map is labelled showing the positions of the Fan, North Shelf, Mid Shelf and Coastal areas. The total Holocene palynomorph abundance shows higher abundance displayed with the larger coloured circles, and follows through to lowest abundance displayed with smallest coloured circles as per legend. 

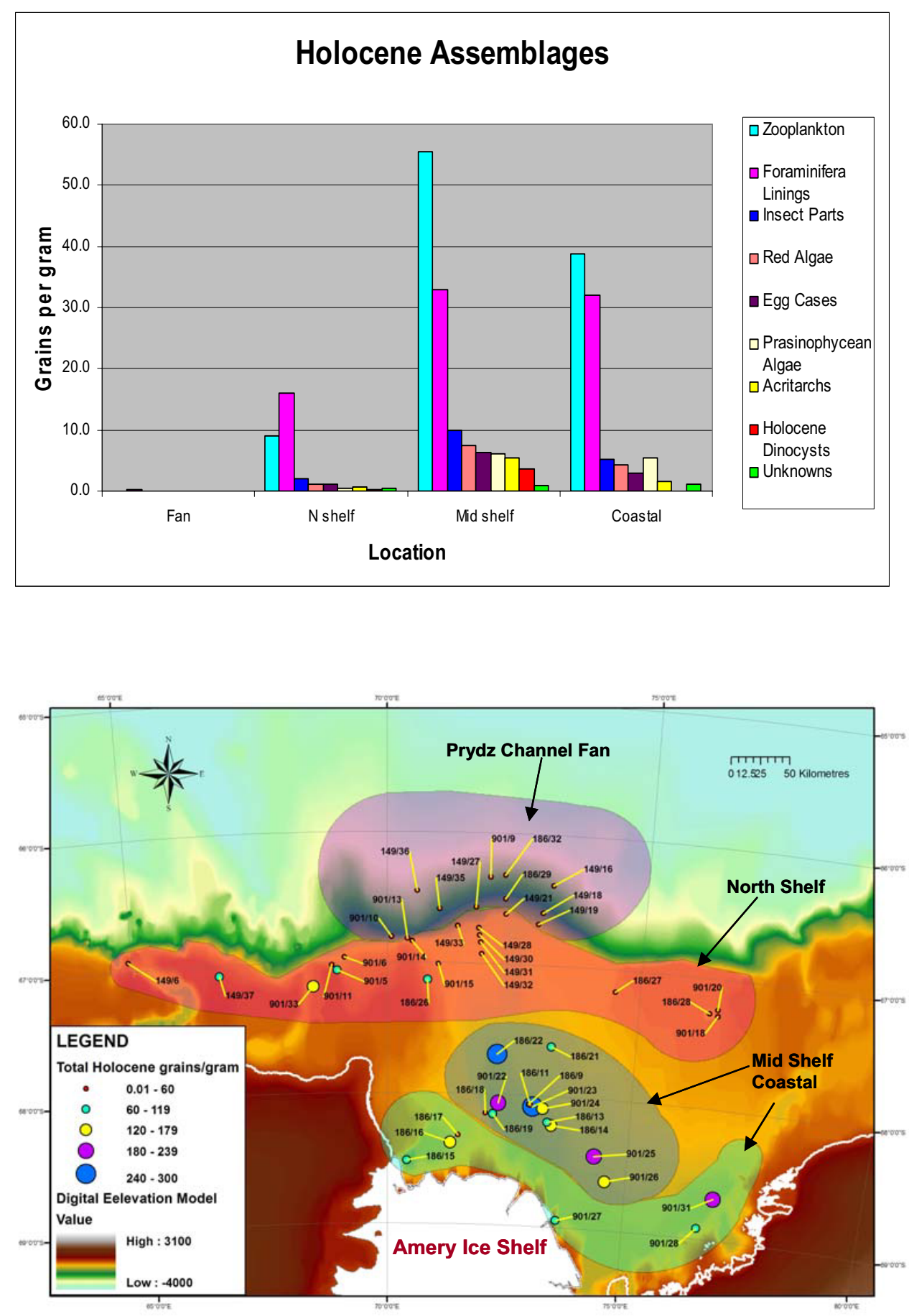

Fig. 3.2: Total Holocene Palynomorphs grains per gram. Graph displays the geographical locations with the individual assemblages. The map is labelled showing the positions of the Fan, North Shelf, Mid Shelf and Coastal areas. The total Holocene palynomorph abundance shows higher abundance displayed with the larger coloured circles and lowest abundance displayed with smallest coloured circles as per legend. 
of all Holocene palynomorphs are either zooplankton (39\%) or foraminiferan linings (33.93\%) (Appendix A).

Zooplankton is dominated by Zooplankton sp. (Plate 8 nos. 7-12 and Plate 9 nos. 1-9) which makes up to $93 \%$ of this category (Appendix A). Zooplankton sp. highest abundances are from the Mid Shelf $(51.33 \mathrm{~g} / \mathrm{g})$, but they also have a strong presence in the Coastal area $(36.65 \mathrm{~g} / \mathrm{g}$ ) (fig 3.3). There is very little representation of this component in the North Shelf area and they are rare on the Fan with only one sample containing specimens of Zooplankton sp. that were damaged and looked reworked due to a darker colouring. Zooplankton sp. must be living in the water column today as many of their cysts are found well preserved and in good condition. The foraminifera (fig 3.4) showed similar distribution to Zooplankton sp. This may mean that they have a similar ecology or it could mean that they are dominating their own ecological niches and not competing for the same types of food and are therefore able to produce large populations.

\subsection{Other palynomorph distributions}

There are some exceptions to Holocene palynomorph concentration dominating the Mid Shelf area. Beringiella sp. (fig 3.5) is the only red alga found in this study and is found in most samples within the embayment and a few samples on the fan. It may be that the Beringiella sp. was more affected by currents within the bay than other palynomorphs. Beringiella sp. rarely appeared folded or flattened in the sediment and its shape (Plate 7 Nos. 4-11) could be described as oval or egg shaped, good for buoyancy and ease of dispersal. As mentioned earlier this species has been found in the Arctic, which has similar environments to Prydz Bay with regard to its ice margins and the tidewater glacier of the Amery Ice Shelf.

Cymatiosphaera sp. 2 (fig 3.6) was also found in abundance in the areas immediately in front of the Amery Ice Shelf and in the Lambert Deep on the western side of the Amery Ice Shelf. The Lambert Deep area was formed by erosion due to glacial advance of the ice shelf but today this area is where the coastal current enters from the eastern side and circulates underneath the ice shelf before exiting from the west where the Lambert Deep is situated. Mudie and Harland (1996) suggest that 


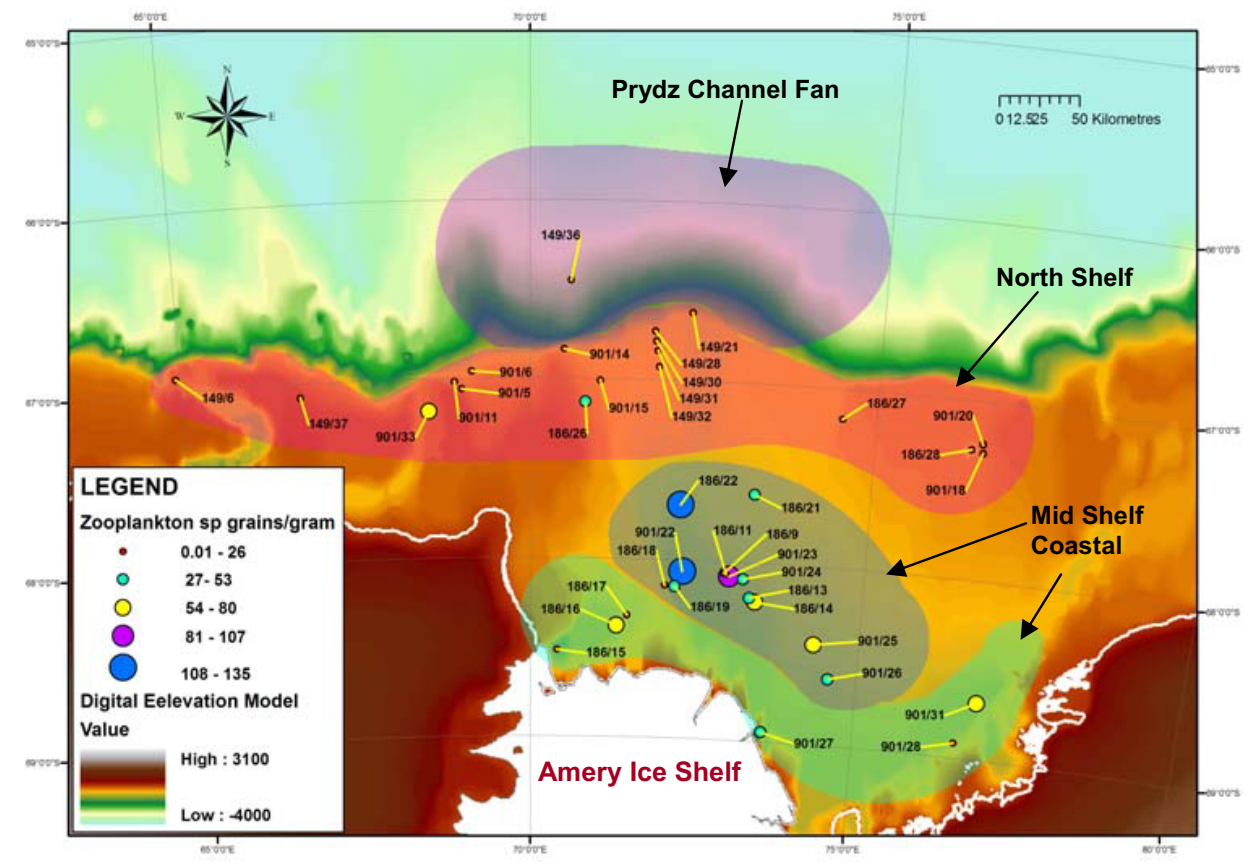

Fig. 3.3: Zooplankton sp. has a higher abundance (larger coloured circles) on the Mid Shelf and Coastal geographic areas, and is sparse on most of the North Shelf and spread over most of the samples there. There is only one sample with a low abundance of Zooplankton species on the Fan.

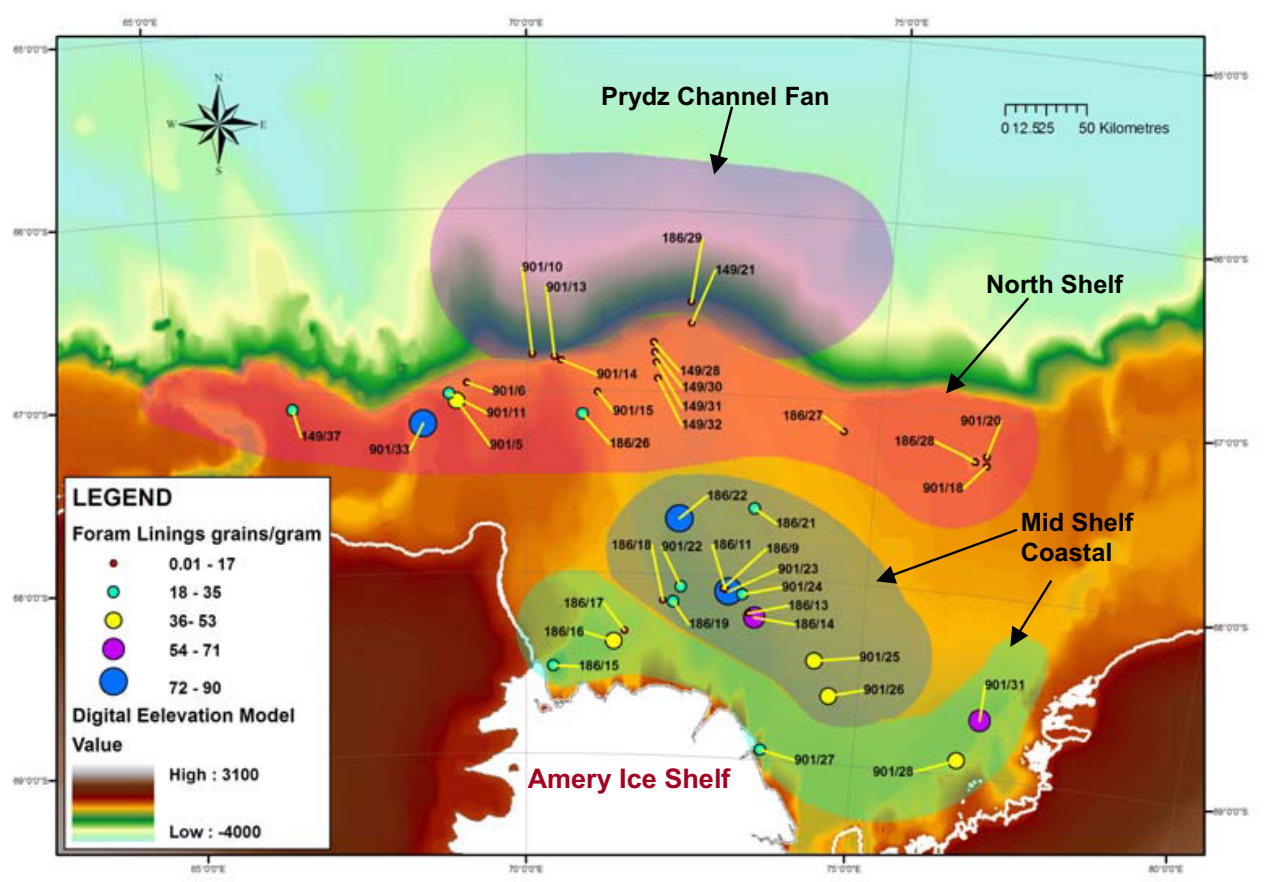

Fig. 3.4: Foraminiferan linings have a higher abundance (larger coloured circles) on the Mid Shelf and Coastal geographic areas but are fewer in number than Zooplankton sp. They have a high abundance on the western North Shelf but are less abundant on other parts of the North Shelf and have a small presence on the Fan. 


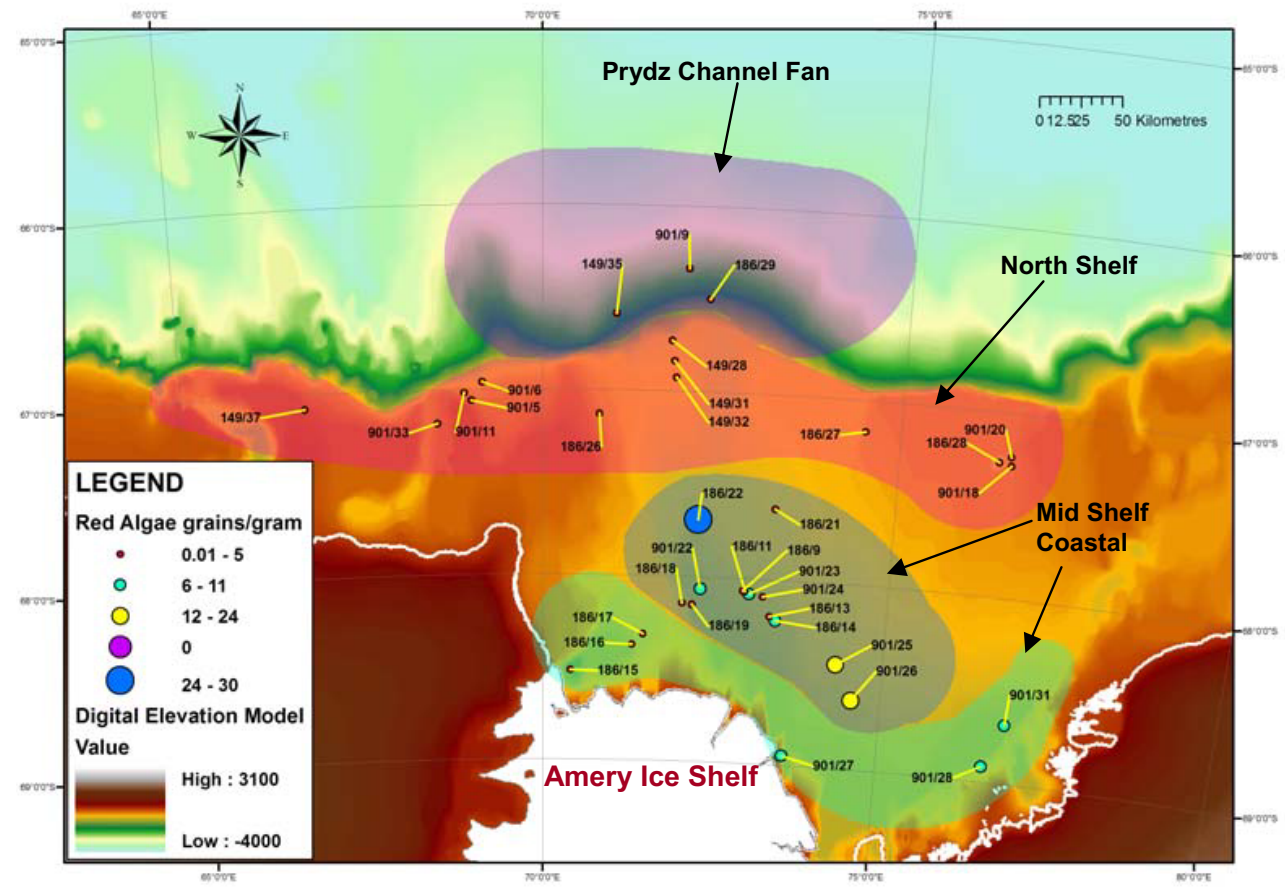

Fig. 3.5: The red algae Beringiella sp. show a higher abundance Mid Shelf (larger coloured circles) with less abundance in the Coastal geographic area. They are also present though sparse on the North Shelf and are rare inin three samples on the Fan.

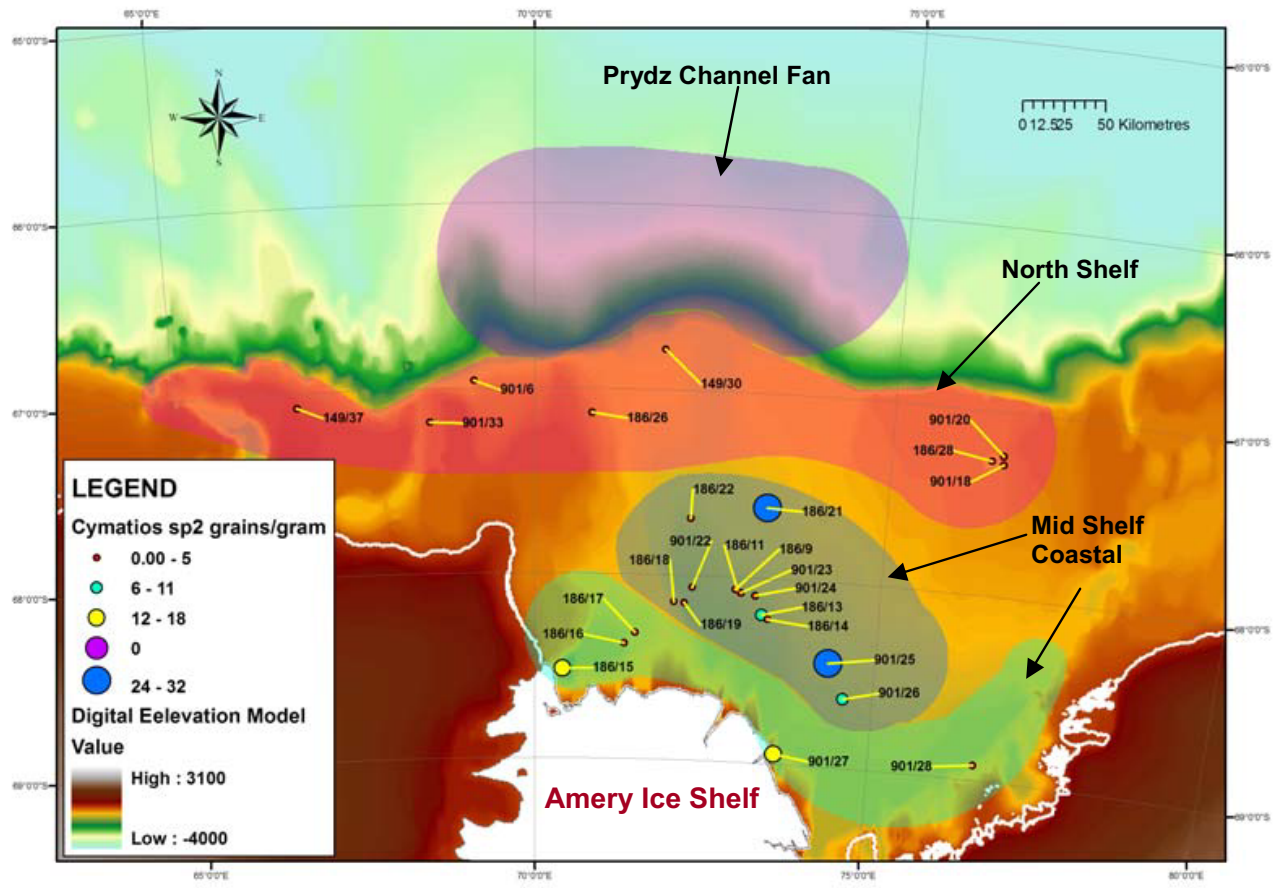

Fig. 3.6: Cymatiosphaera sp. 2 unlike the red algae is not present on the Fan and is sparse on the North shelf. They have a high abundance (larger coloured circles) on the Mid Shelf and in the Coastal areas especially in front of the Amery Ice Shelf. 
Cymatiosphaera spp. are most common in upwelling areas in the Arctic but in Prydz Bay this species appears in the surface sediments close to the ice shelf. This may indicate a preference for lower salinity (fig 3.7) and/or colder currents circulating under the ice shelf, rather than the more saline oceanic waters imported by the circulation of the Prydz Bay Gyre. This species is not as common in the more shallow areas of the bay where the surface currents are stronger and the salinity is higher.

The unknowns (Appendix D) have a total count of 95 palynomorphs. All the unknowns were located in the continental shelf and the highest concentration was in the coastal area, which makes this category an exception to the dominance of palynomorphs found in the Mid Shelf. The most abundant species of unknowns is species 6 at $41.90 \%$ and its location is similar to the prasinophyte and red algae locations which suggest that this species may be algal in origin.

The highest counts (Appendix A) for insect parts and egg cases confined them mostly to the continental shelf area, with their highest concentration in the Mid Shelf at 9.85 grains per gram.

\subsection{Reworked $v$ Holocene dinoflagellate cysts}

The surface sediment samples obtained for this project are considered to be modern and in some areas of Prydz Bay, for example the Prydz Bay Channel, they have produced extant dinocysts. Figure 3.8 shows the distribution in the bay for Holocene dinocysts. They are abundant in the Mid Shelf but are rare in other locations. According to Dale (1996) a glaciomarine signal is provided by the dominance of a single species. This is consistent with the Holocene dinocyst Selenopemphix antarctica, which is present within the bay at more than three times the number of any other dinocyst. Cryodinium sp. and Protoperidinioid sp. 2 are the next most abundant types. The appearance of two cosmopolitan gonyaulacoid dinocysts, the Impagidinium sp. and Alisocysta sp. which are normally restricted to open waters, suggest that oceanic waters are entering the embayment (Dale, 1996). 25\% of all dinocyst counted are reworked (fig 3.9), and all these are recognised as part of the 


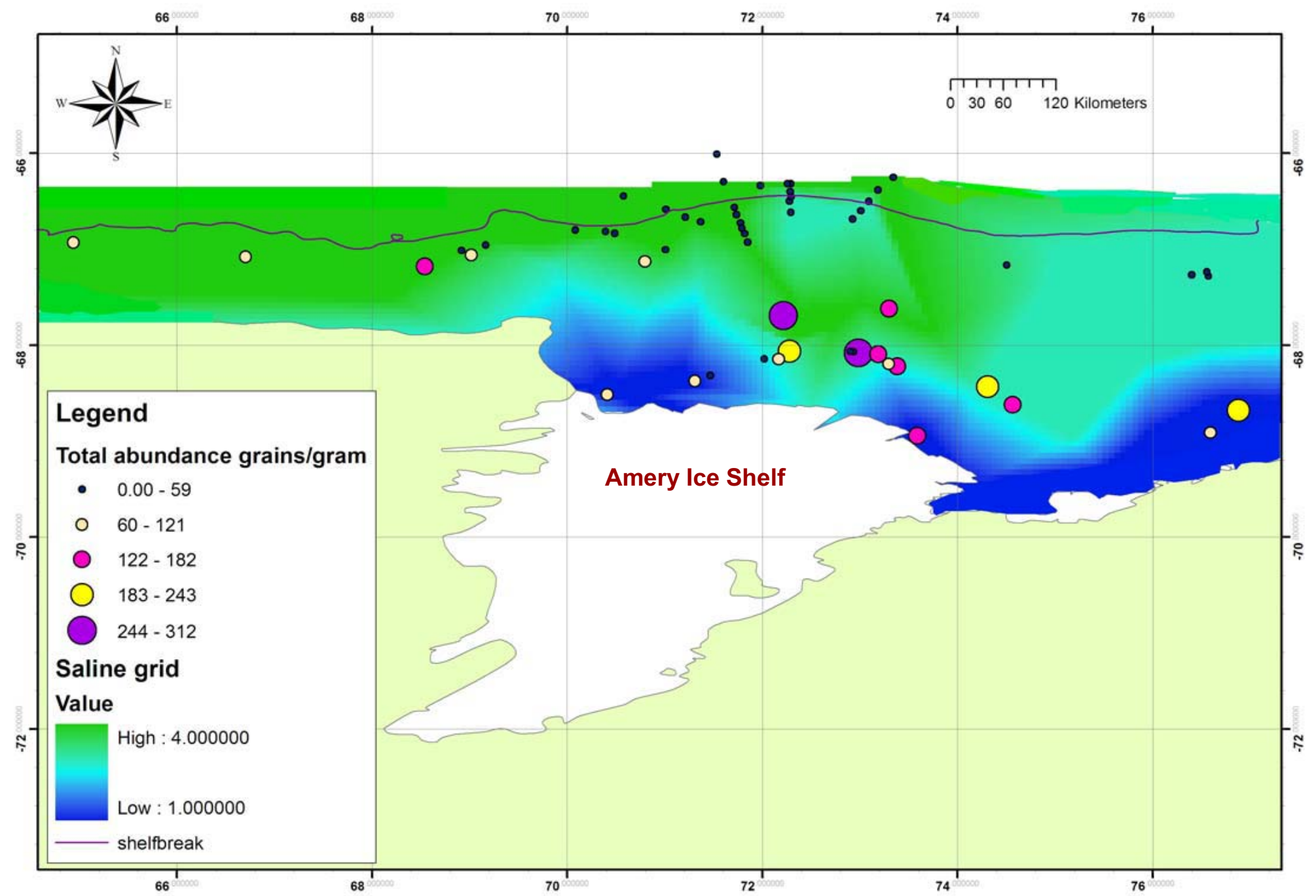

Fig 3.7: Prydz Bay salinity contour map showing higher salinity, dark green through to lower salinity, dark blue. A compilation was selected by Taylor, McMinn \& Franklin (1997) table 1, from data collected on separate cruises by ANARE, FIBEX, SIBEX II and 

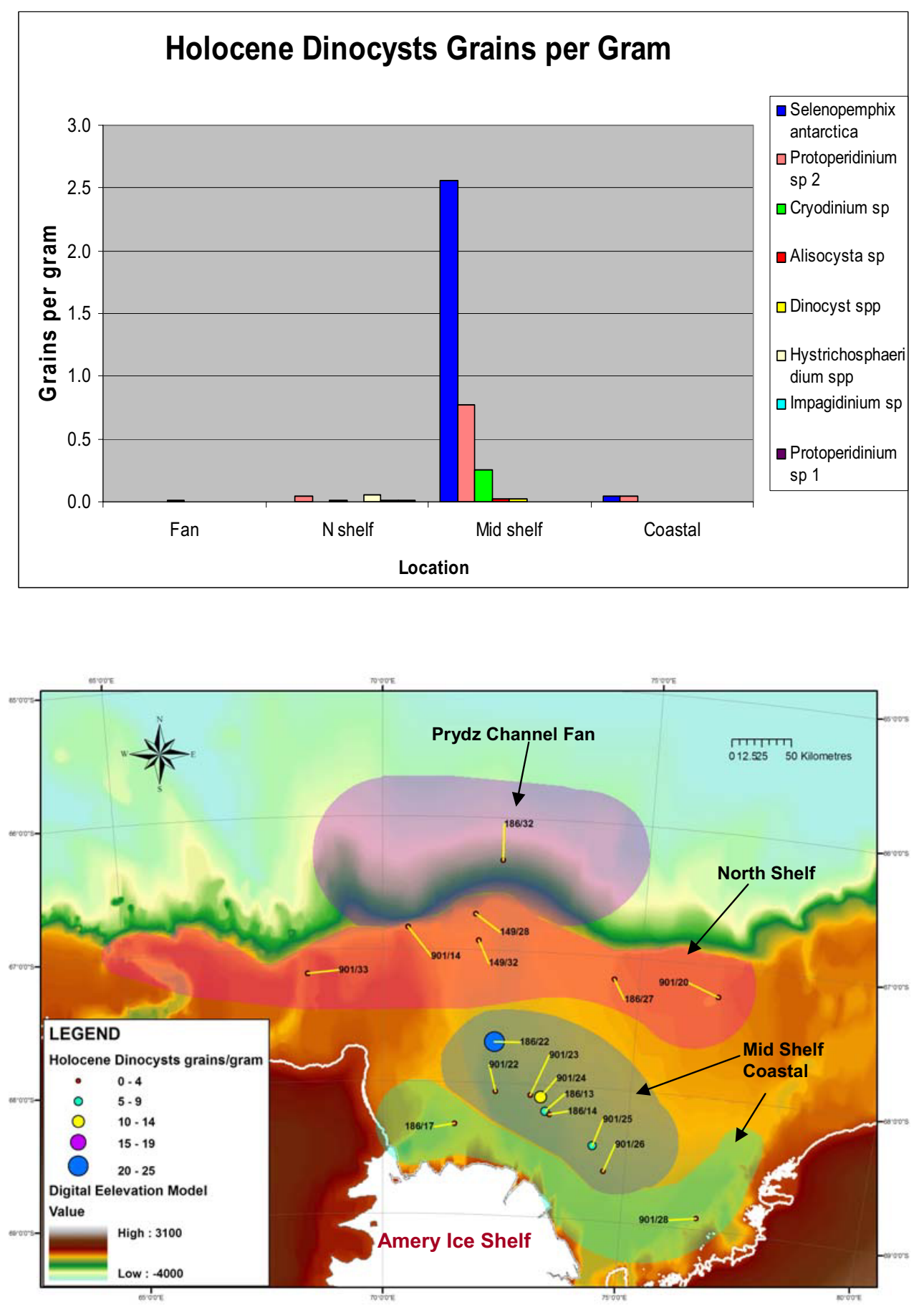

Fig. 3.8: Holocene dinocysts grains per gram. Graph displays the geographical locations with the individual assemblages. The map is labelled showing the positions of the Fan, North Shelf, Mid Shelf and Coastal areas. The Holocene dinocyst abundance shows higher abundance displayed with the larger coloured circles and lowest abundance displayed with smallest coloured circles as per legend. 

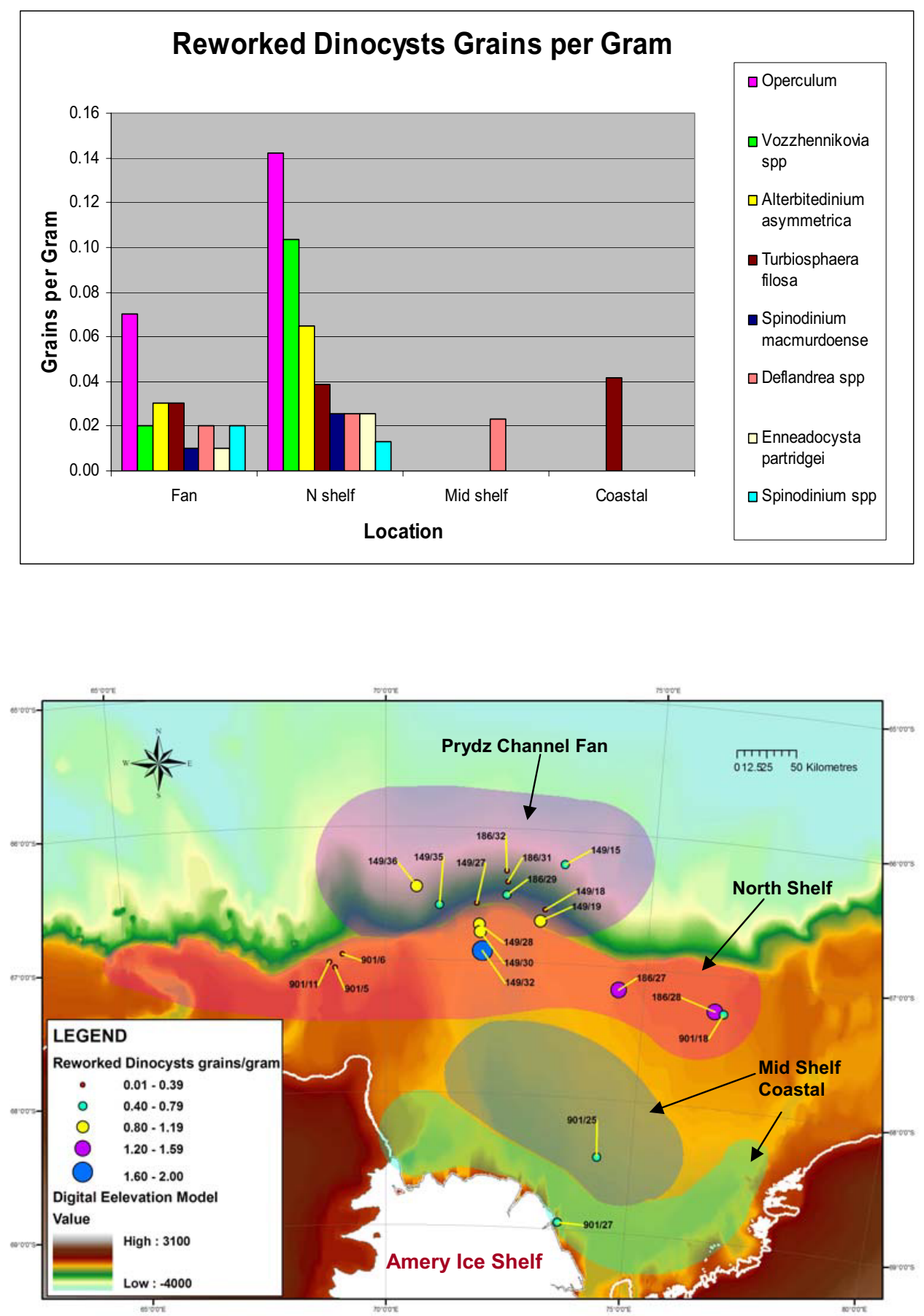

Fig. 3.9: Reworked dinocysts grains per gram. Graph displays the geographical locations with the individual assemblages. The map is labelled showing the positions of the Fan, North Shelf, Mid Shelf and Coastal areas. The reworked dinocyst abundance shows higher abundance displayed with the larger coloured circles and lowest abundance displayed with smallest coloured circles as per legend. 
Transantarctic Flora initially reported in the McMurdo Erratics (Levy \& Harwood, 2000b) and Eocene in age, with their highest counts recorded in the North Shelf and Fan areas. Turbiosphaera filosa is the only reworked dinocyst recorded in the Coastal area and Deflandrea sp. the only reworked dinocyst recorded in the Mid Shelf.

\subsection{Terrestrial material (reworked)}

The reworked dinocysts mentioned above make up approximately $2 \%$ of the total reworked palynomorph count, the other $98 \%$ being terrestrial material (Appendix A) consisting of fragments of charcoal, pollen grains and spores. Figure 3.10 shows that pollen grains and spores have high abundances on the Fan and North Shelf, with decreasing amounts from Mid Shelf and Coastal areas.

There is a mix of terrestrial material found among the modern marine palynomorphs in the Mid Shelf and Coastal areas which may be explained by the Prydz Bay Gyre distributing this material. Other factors may include iceberg ploughing and strong currents in shallow areas that have disturbed sediment where the terrestrial material is most abundant. The material may also be carried into the bay by the coastal currents from the east which have been discussed by Truswell (1983) with regard to the composition, distribution and origin of recycled material on the East Antarctic continental shelf. Truswell (1983) suggested that recycled palynomorph concentrations may be from the erosion of sedimentary sequences on the eastern continental shelf which would be carried to Prydz Bay by the coastal current.

\subsection{Total Holocene and reworked palynomorphs}

A notable difference between total Holocene and total reworked palynomorphs is in the total counts. Total count for Holocene palynomorphs $(10,097)$ are approximately four times greater than the total count for reworked palynomorphs $(2,630)$ (Appendix A). Graphical results for absolute abundance of total Holocene and reworked grains per gram shows the uneven distribution that is occurring between the Holocene and reworked palynomorphs (fig 3.11). The graph emphasises the dominance of Holocene palynomorphs on the Mid Shelf and Coastal geographic areas which confines them to the deeper parts of the continental shelf. The North 
Shelf shows that Holocene palynomorphs are lower in abundance here but still slightly higher than all reworked palynomorphs. In contrast the much lower counts for total reworked palynomorphs show a more even distribution on the Fan and North Shelf geographic areas, but are sparse in the deeper Mid Shelf and Coastal geographic areas. The map displays the overall abundance for palynomorphs and confirms that highest abundances are in the Mid Shelf and Coastal areas and that abundance is lower on the North Shelf and even lower on the Fan. 

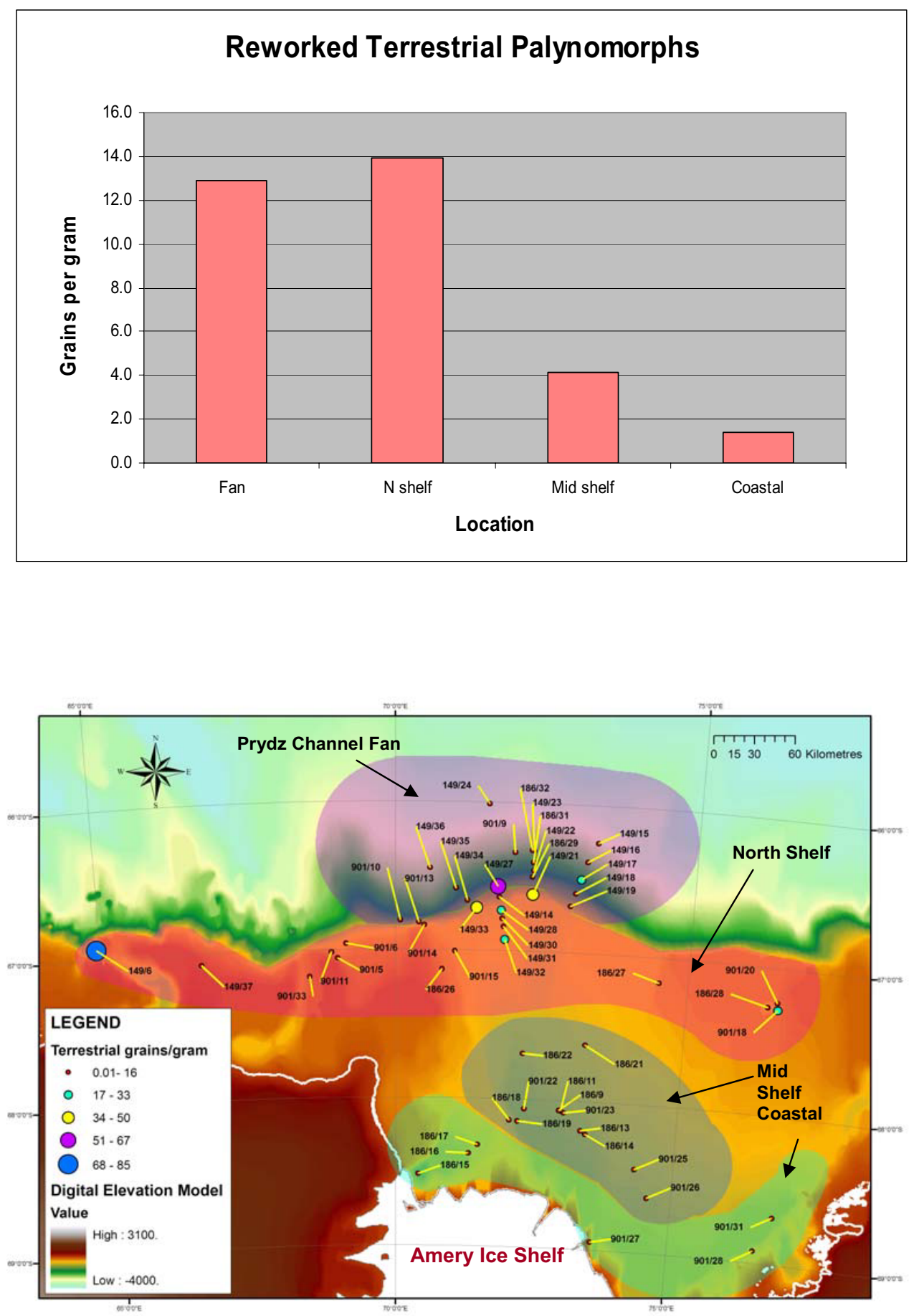

Fig. 3.10: Terrestrial palynomorphs consist of pollen grains and spores. The large coloured circles are the higher abundances and are mostly on the Northern Shelf. There is a scattering of terrestrial material on the inner shelf which must have been transported there by the coastal currents or the gyre. The graph displays the terrestrial material with the highest abundance on the North Shelf followed by the Fan and small counts Mid Shelf and Coastal. 

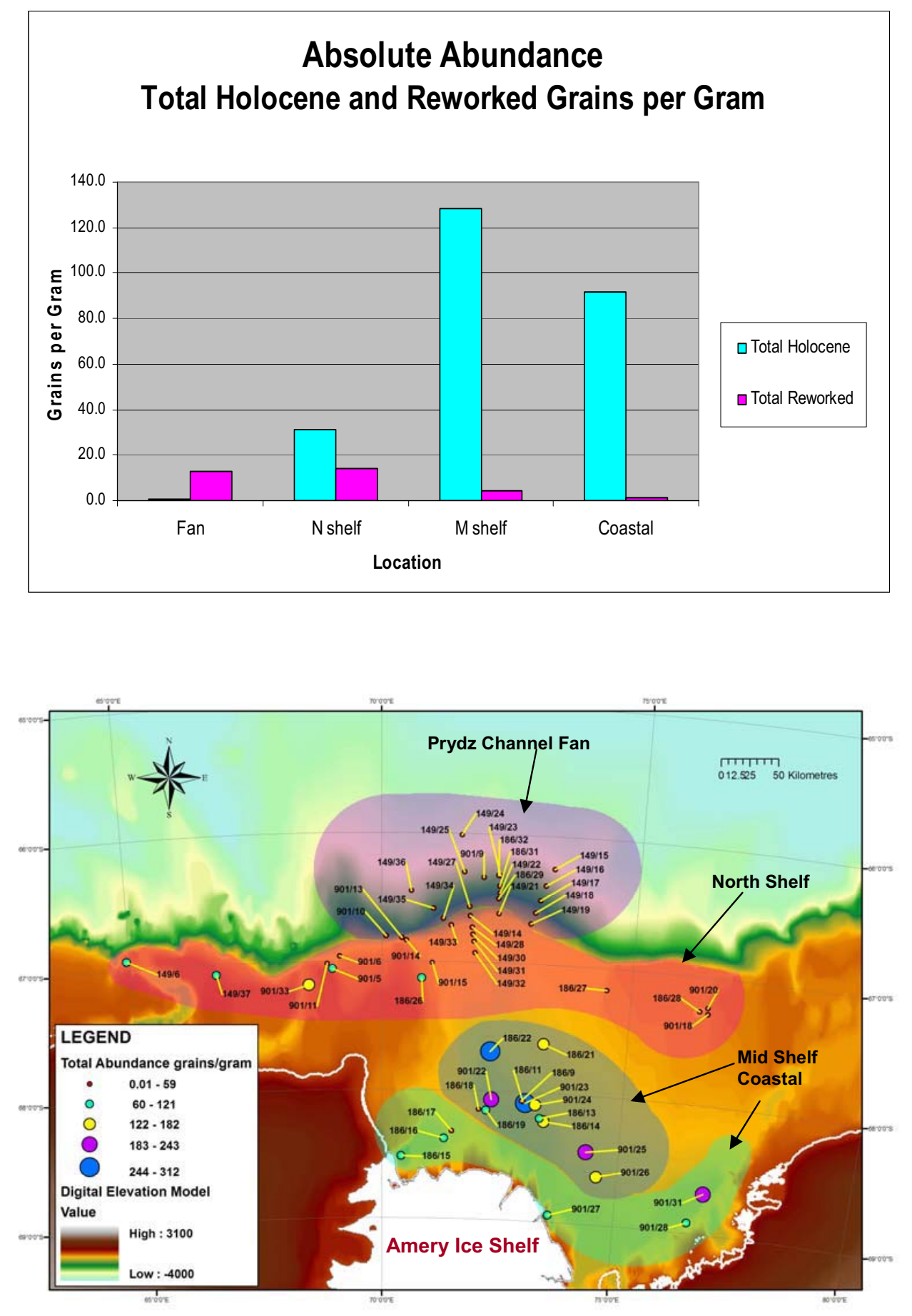

Fig. 3.11: Absolute abundance of grains per gram. Graph displays the geographical locations of total Holocene and total reworked assemblages. The map is labelled showing the geographic locations of the Fan, North Shelf, Mid Shelf and Coastal areas. The absolute abundance shows higher abundance displayed with the larger coloured circles and lowest abundance displayed with smallest coloured circles as per legend. 


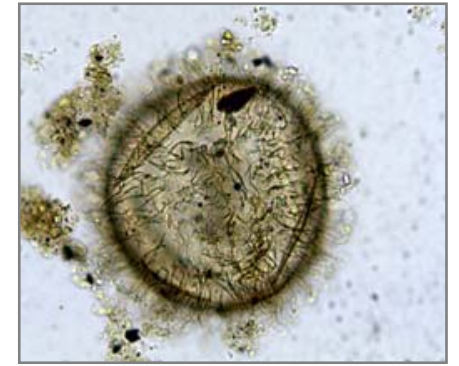

1
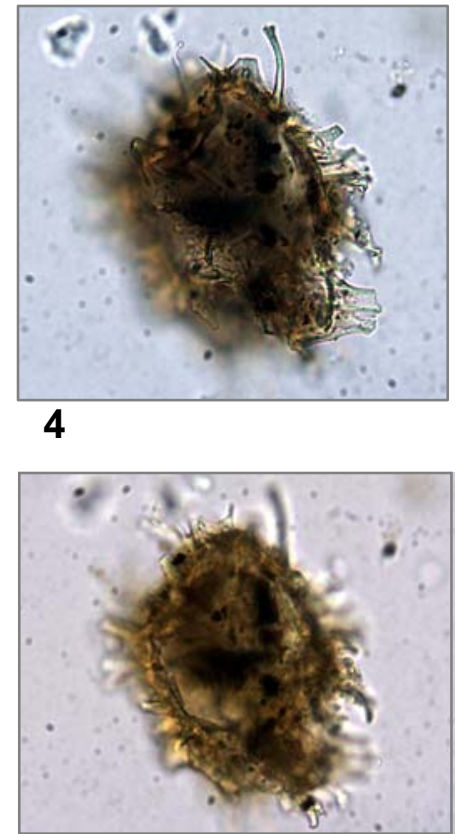

7

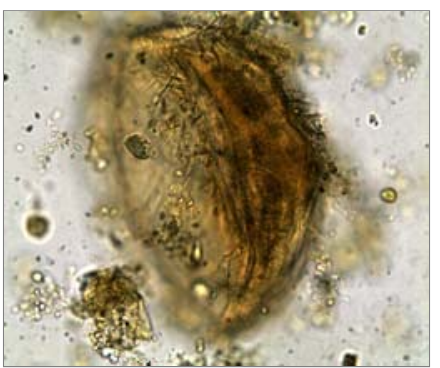

10

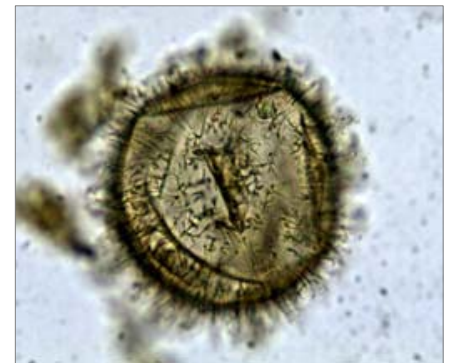

2
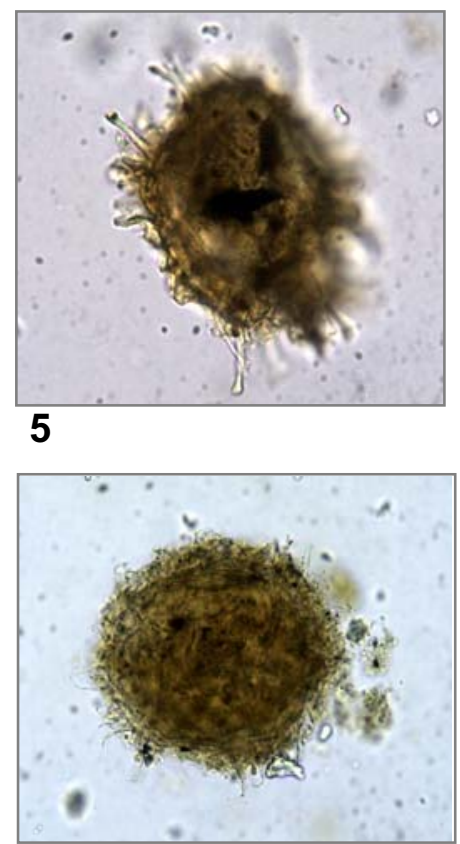

8

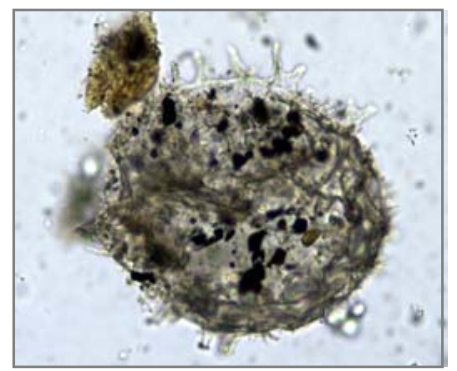

11

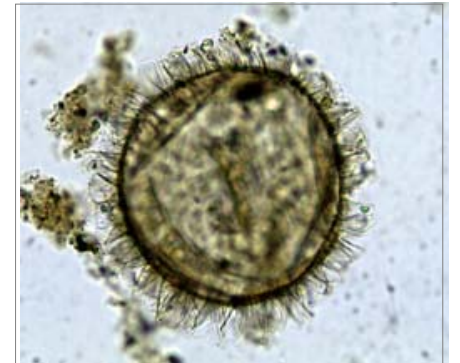

3
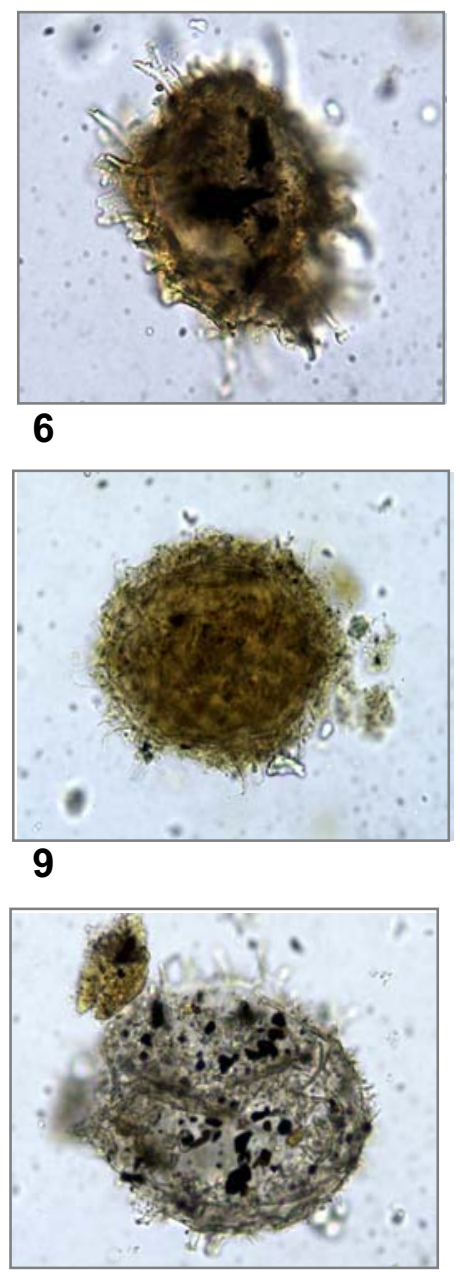

12

\section{Illustrative Plates}

Plate 1 - Fig. 1-3 Acritarch sp 1, longest dimensions in $\mu \mathrm{m}=125 \mu \mathrm{m}$, slide number = 901-25-3B, England finder co-ordinates = O28/1; Fig. 4-7 Acritarch sp 2, $75 \mu \mathrm{m}, 901-26-$ 1B, C32/3; Fig. 8 Acritarch sp 3, $125 \mu \mathrm{m}$ 186-22-2A, V38/2; Fig 9-10 Acritarch sp 3, 125 $\mu \mathrm{m}$ 186-22-3B J53/1; Fig. 11-12 Acritarch sp 4,125 $\mu \mathrm{m}$ 186/18-3A Q49/3. 

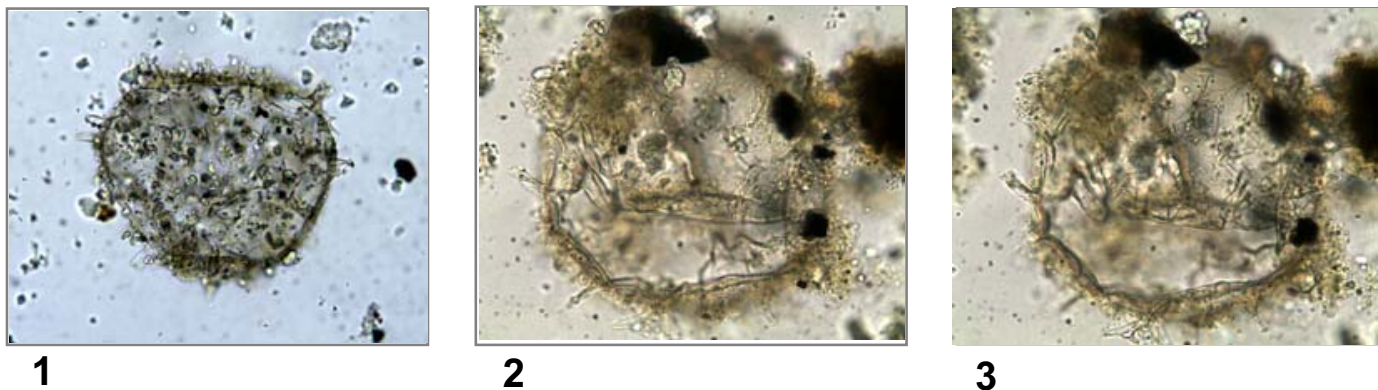

3

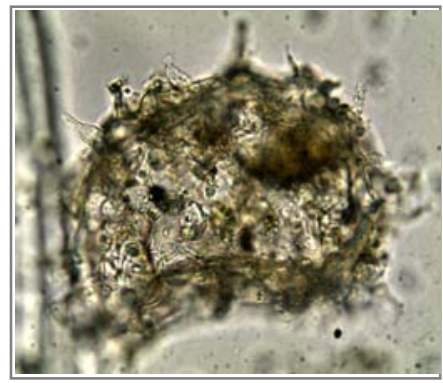

4

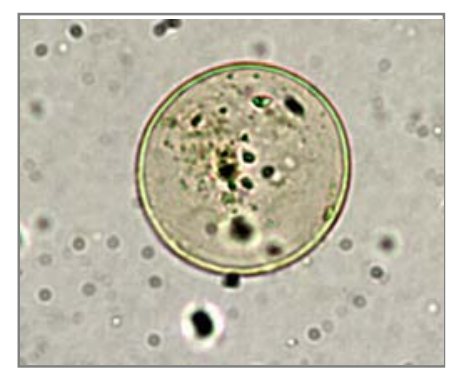

5

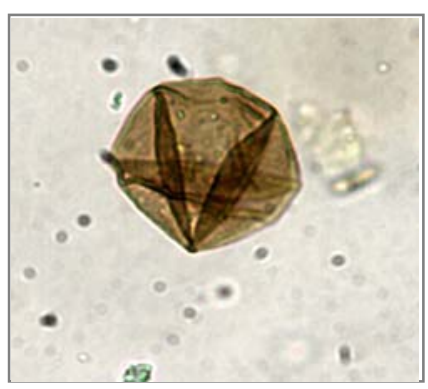

6

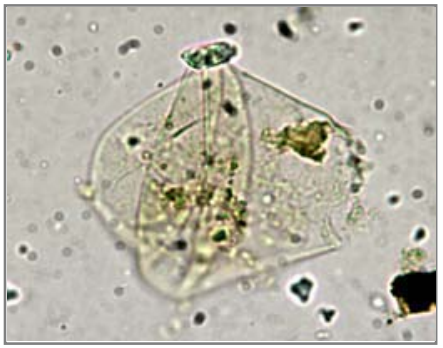

7

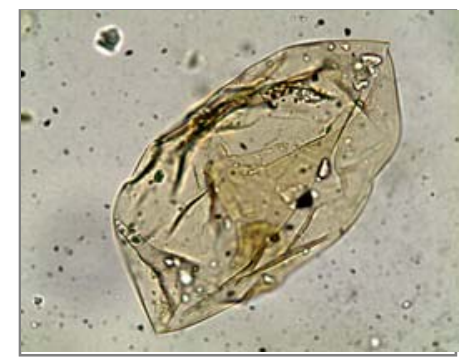

8

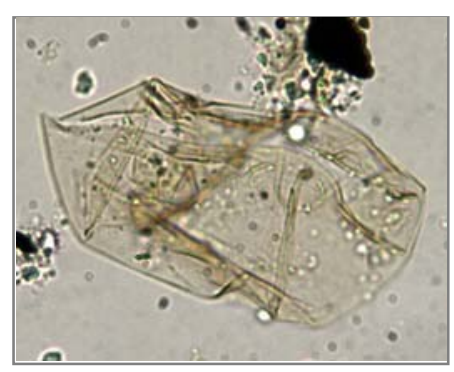

9

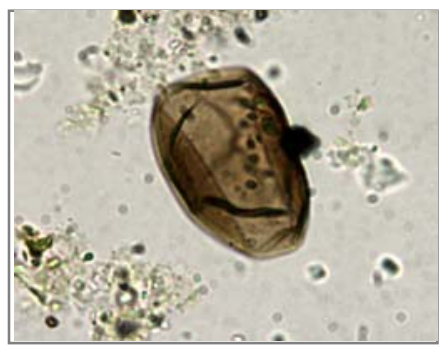

10

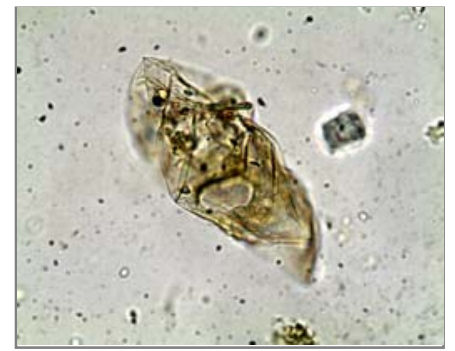

11

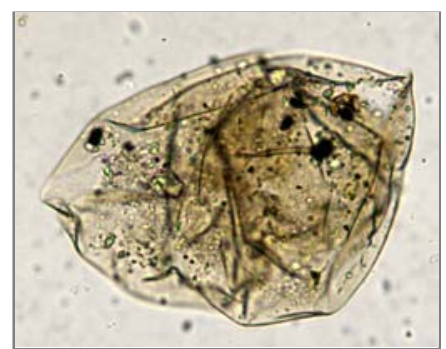

12

Plate 2 - Fig. 1 Acritarch sp $4125 \mu \mathrm{m}, 186-9-3 A$, C28; Fig. 2-3 Acritarch sp 4, 125 $\mu \mathrm{m}, 901-23-2 A$, B43; Fig. 4, Acritarch sp $150 \mu \mathrm{m}, 901-25-3 \mathrm{~A}$, X47; Fig 5 Leiospherida sp, $35 \mu \mathrm{m}, 901-33-3 \mathrm{~A}$, J49.2; Fig. 6 Sphaeoromorph, $30 \mu \mathrm{m}$ 186-13-2A, Y39; Fig 7, Sphaeoromorph, $60 \mu \mathrm{m}, 901 / 33-3 \mathrm{~A}$, P45; Fig. 8, Sphaeoromorph $145 \mu \mathrm{m}, 186-13-2 \mathrm{~A}$, X45; Fig. 9, Sphaeoromorph $85 \mu \mathrm{m}, 901-23-3 \mathrm{~A}$, S49/4; Fig. 10, Sphaeoromorph, 50 $\mu \mathrm{m}, 186-13-1 \mathrm{~B}$ X32/3; Fig. 11, Sphaeoromorph $100 \mu \mathrm{m}, 186-22-2 \mathrm{~A}, \mathrm{~K} 37 / 3$; Fig. 12, Sphaeoromorph $150 \mu \mathrm{m}$, 901-23-3A, R33/1. 


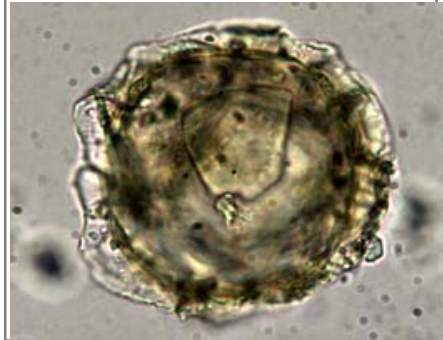

1
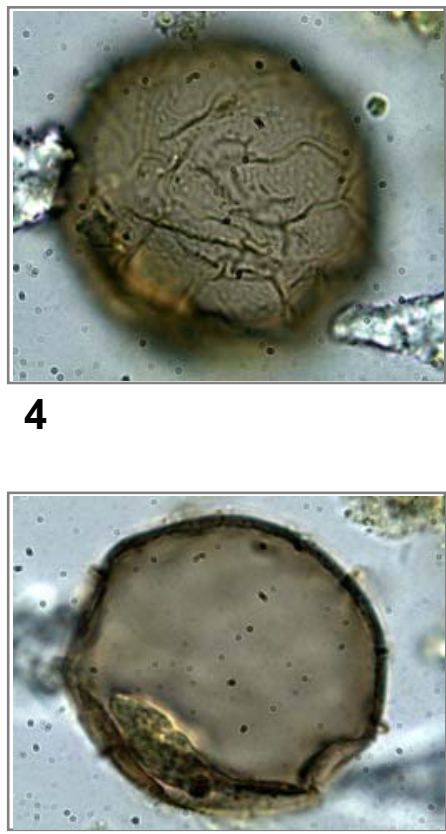

7

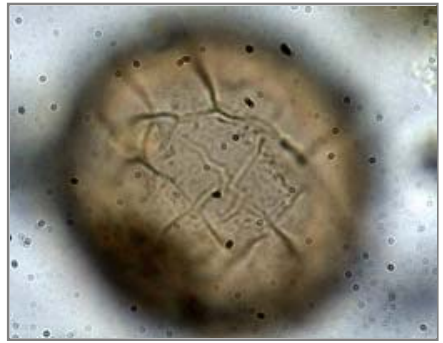

10

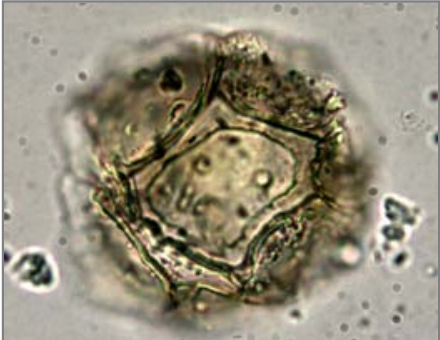

2

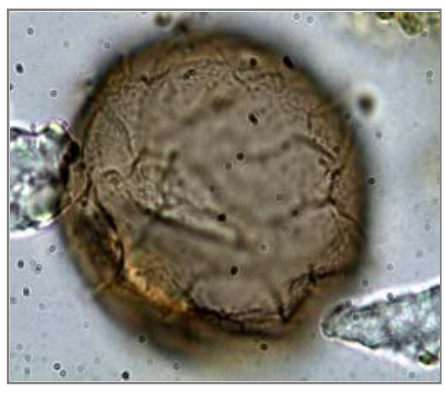

5

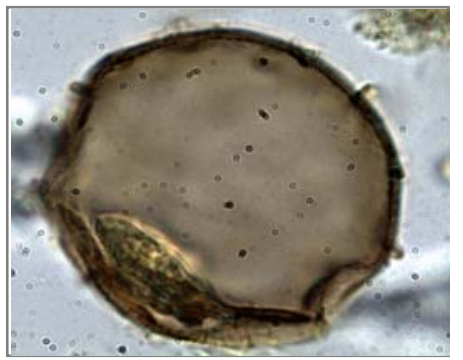

8

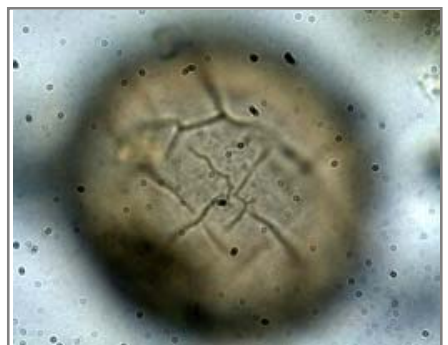

11

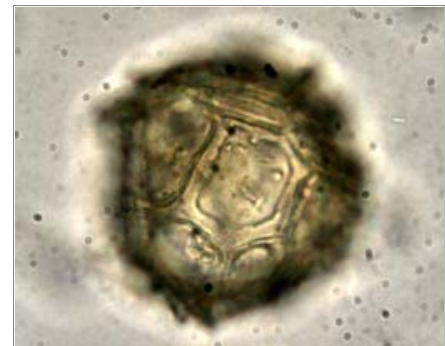

3
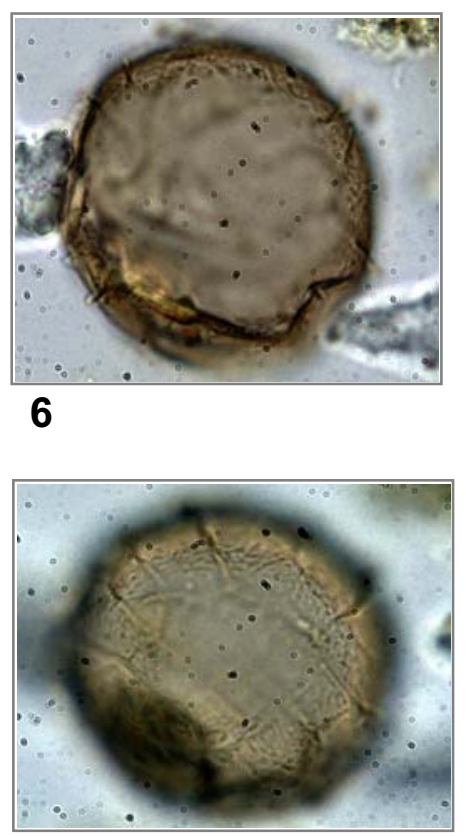

9

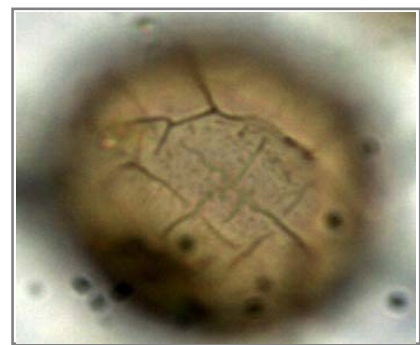

12

Plate 3 - Fig. 1-3 Alisocysta sp, $75 \mu \mathrm{m}, 186-32-2 A$, L33; Fig. 4-12 Cryodinium sp, $35 \mu \mathrm{m}, 186-22-2 \mathrm{~B}, \mathrm{O} 33 / 1$ 


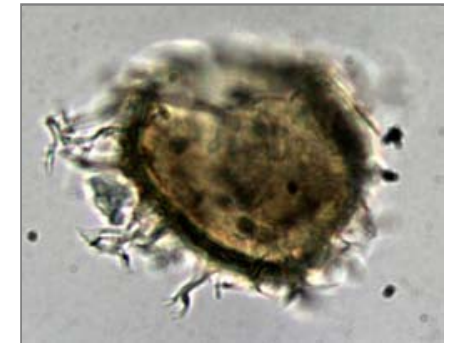

1

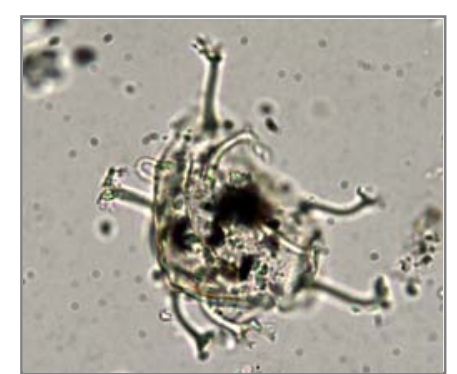

4

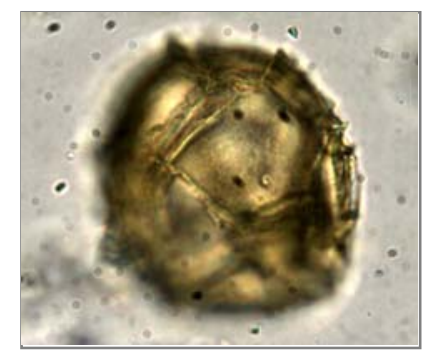

7

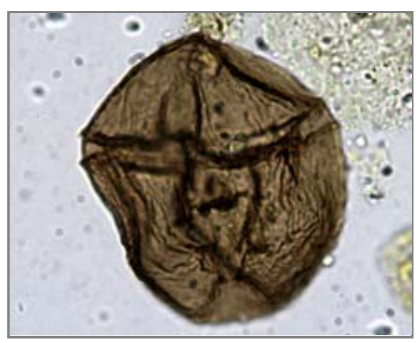

10

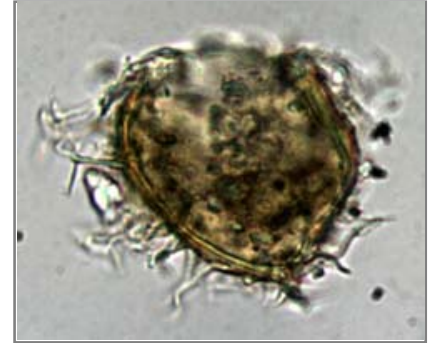

2

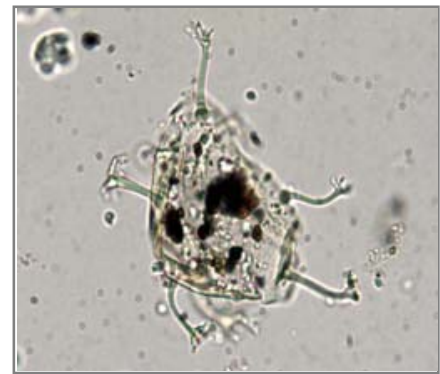

5

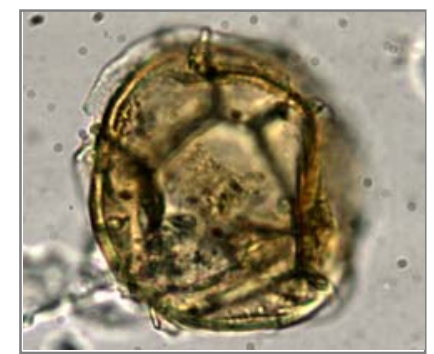

8

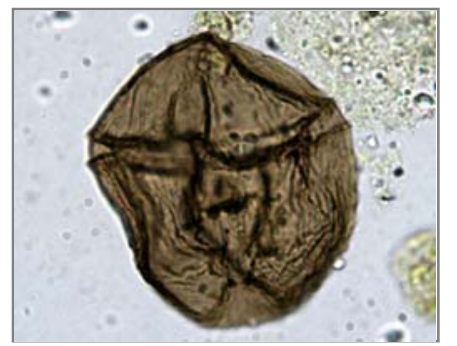

11

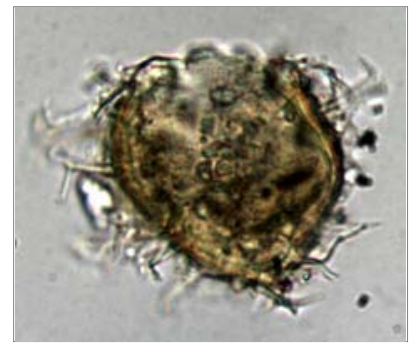

3

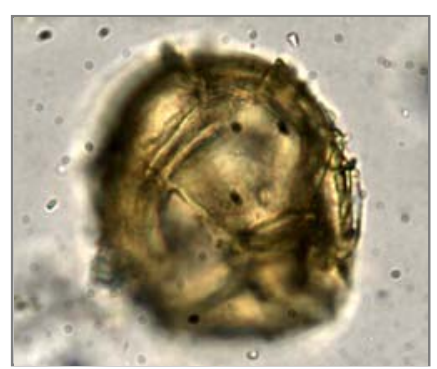

6

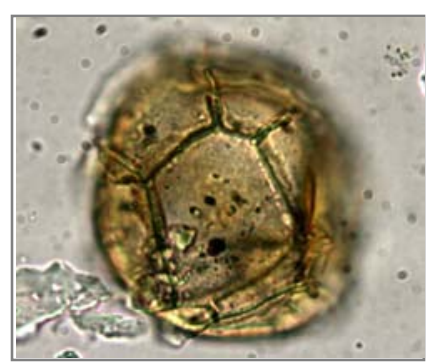

9

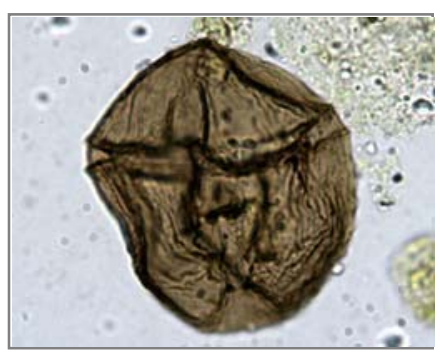

12

Plate 4 - Fig. 1-3 Dinocyst sp, $60 \mu \mathrm{m}, \quad 186-29-2 \mathrm{~A}, \quad X 34 / 2$; Fig. 4-5 Hystrichosphaeridium sp, $75 \mu \mathrm{m}, 149-28-3 \mathrm{~A}$ N35; Fig. 6-9 Impagidinium sp, $60 \mu \mathrm{m}, 901$ 20-3A V38/3; Fig. 10-12 Protoperidinium sp 2, $75 \mu \mathrm{m}, 186-22-3$ A U53/3 


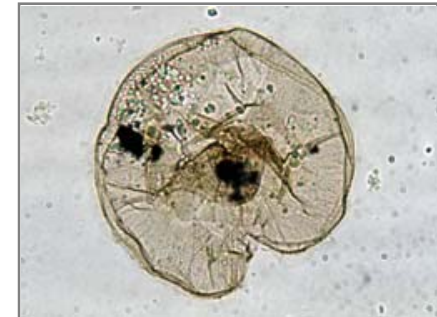

1

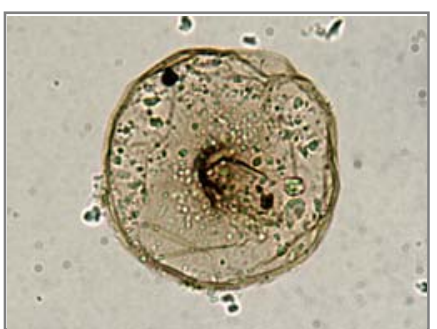

4

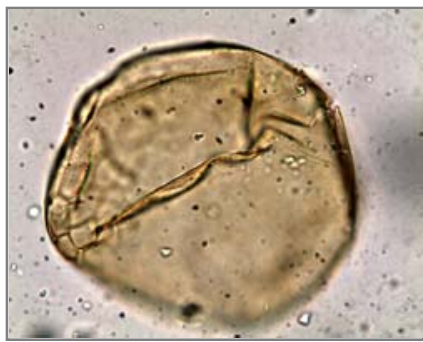

7

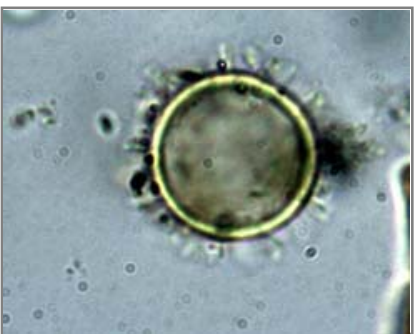

10

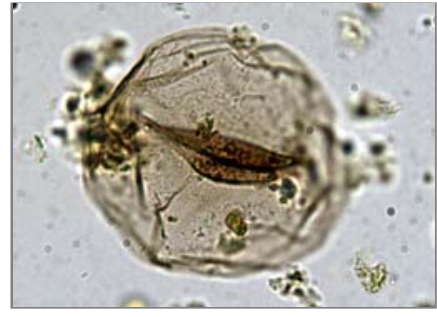

2

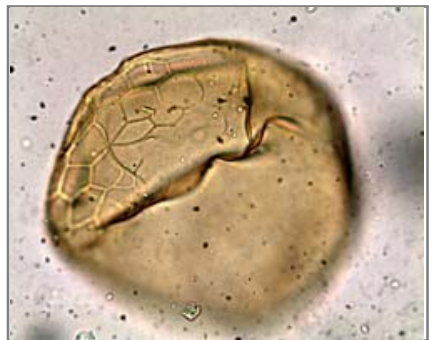

5

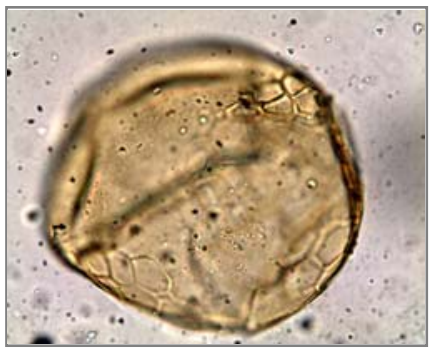

8

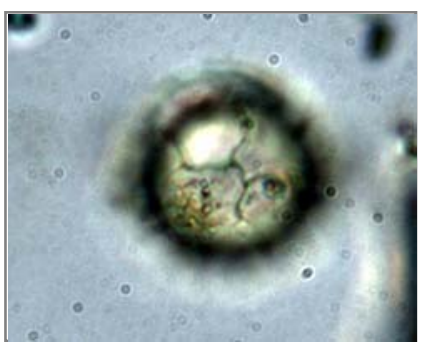

11

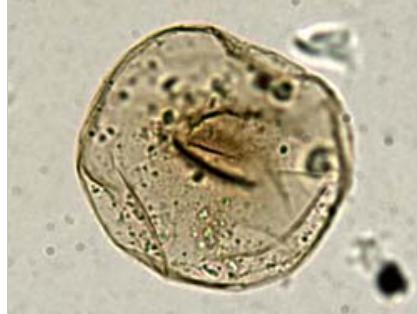

3

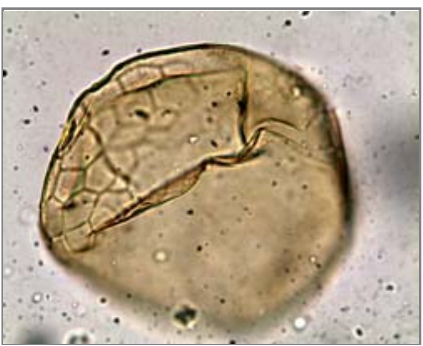

6

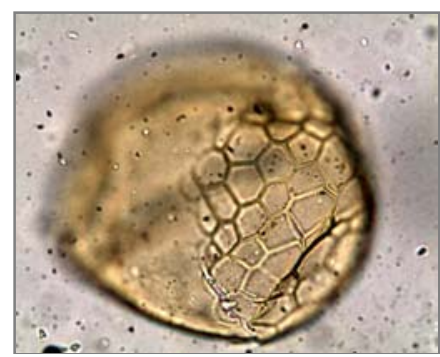

9

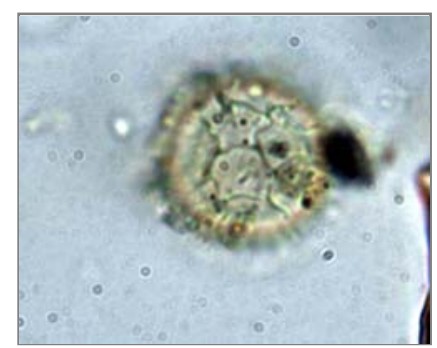

12

Plate 5 - Fig. 1 Selenopemphix antarctica $75 \mu \mathrm{m}, 186-22-1 \mathrm{~A}$ B52/3; Fig. 2 Selenopemphix antarctica $75 \mu \mathrm{m}, 186-22-3 B$ H47/1; Fig. 3 Selenopemphix antarctica 75 $\mu \mathrm{m}$, 901-24-2B G52/1; Fig. 4 Selenopemphix antarctica $75 \mu \mathrm{m}, 901-24-2 A$ T29; Fig. 5-9 Protoperidinium sp $115 \mu \mathrm{m}$ 901-14-2A B60/1; Fig. 10-12 Cymatiosphaera sp $118 \mu \mathrm{m}$ 149-6-1B T49 


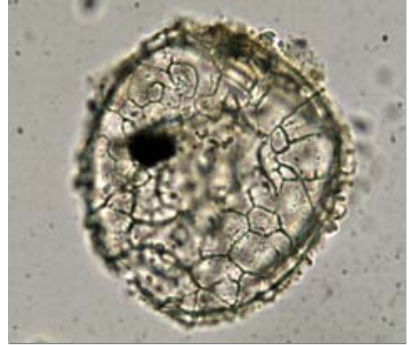

1

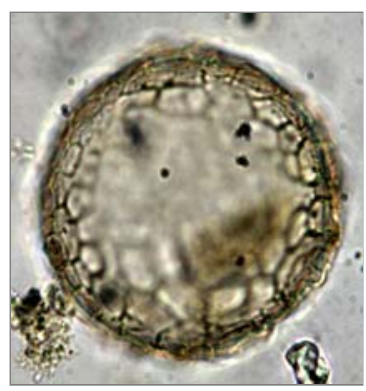

4

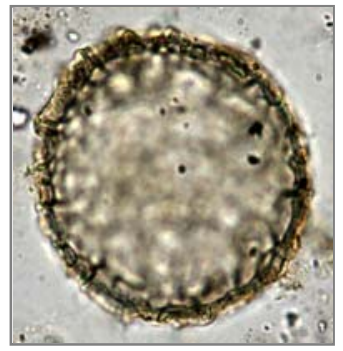

7

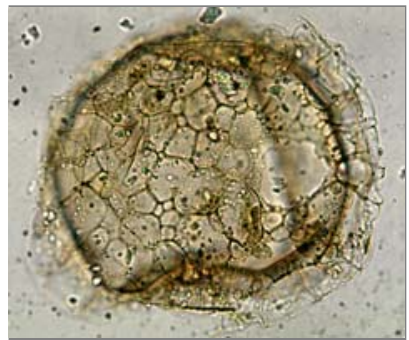

10

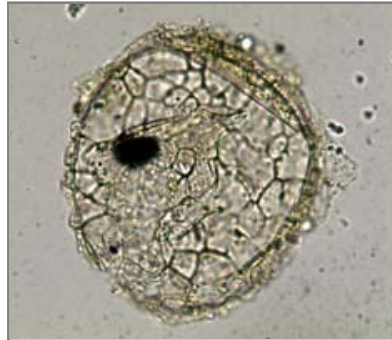

2

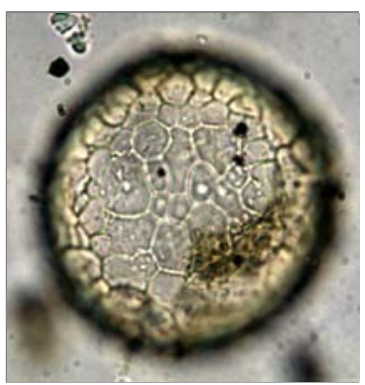

5

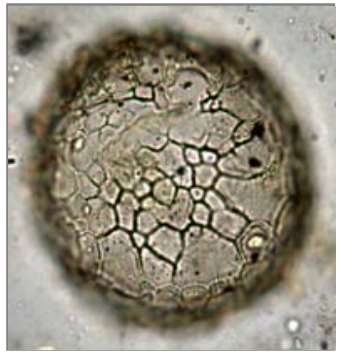

8

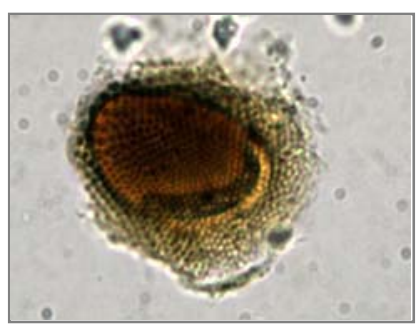

11

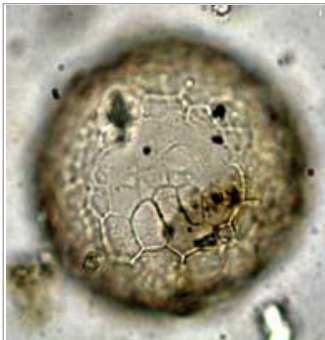

3

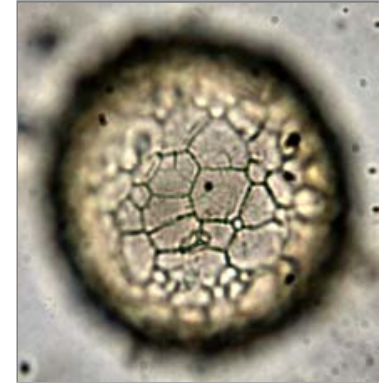

6

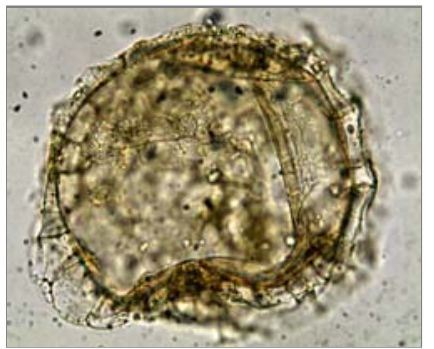

9

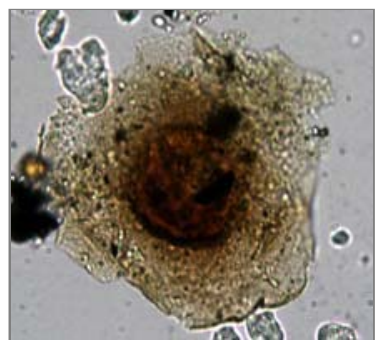

12

Plate 6 - Fig. 1-2 Cymatiosphaera sp $275 \mu \mathrm{m}$, 901-23-3A V30; Fig. 3-5 Cymatiosphaera sp 2, $80 \mu \mathrm{m}, 901-26-2 \mathrm{~B}$ C39; Fig. 6-8 Cymatiosphaera sp 2, $85 \mu \mathrm{m}$, 901-20-2B G30/3; Fig. 9-10 Cymatiosphaera sp 2, $115 \mu \mathrm{m}, 149-37-3 \mathrm{~A}$, F46; Fig. 11-12, Pterospermella sp, $40 \mu \mathrm{m}, 901-33-3 \mathrm{~A}$, L47/3; Fig. 12, $75 \mu \mathrm{m}, 901-23-1 \mathrm{~A}, \mathrm{R} 44 / 2$ 


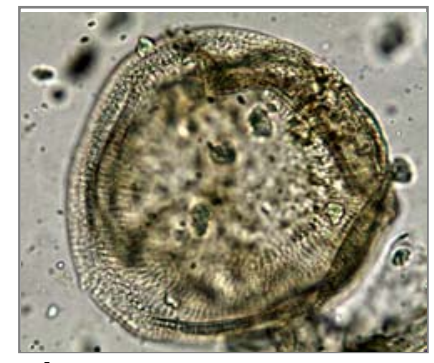

1

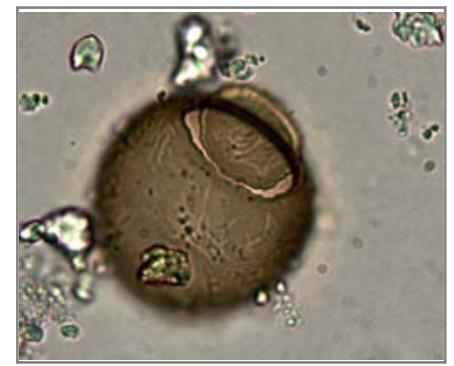

4

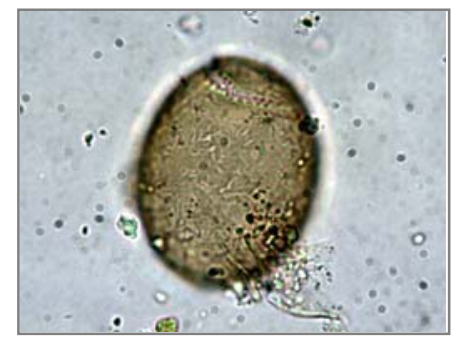

7

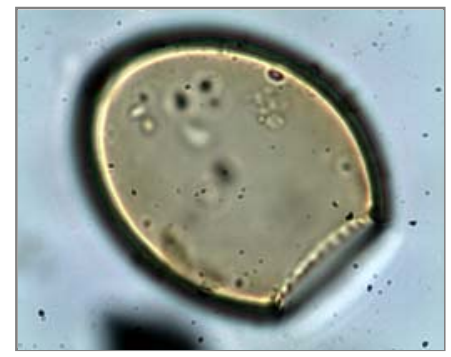

10

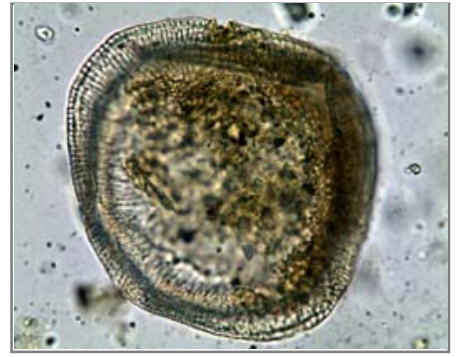

2

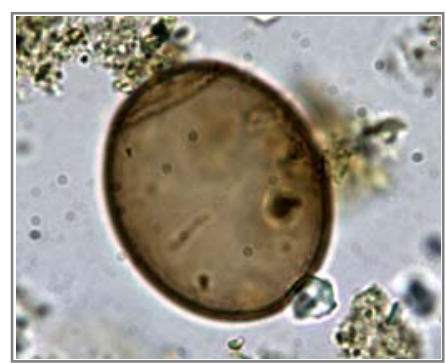

5

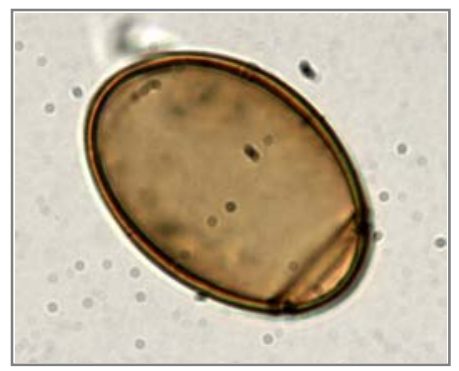

8

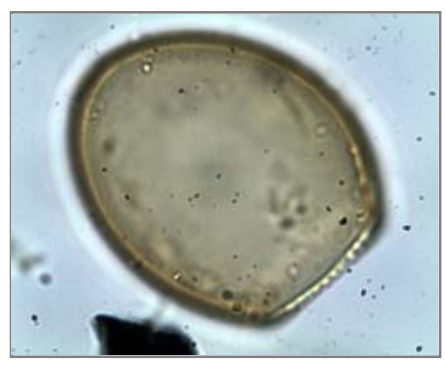

11

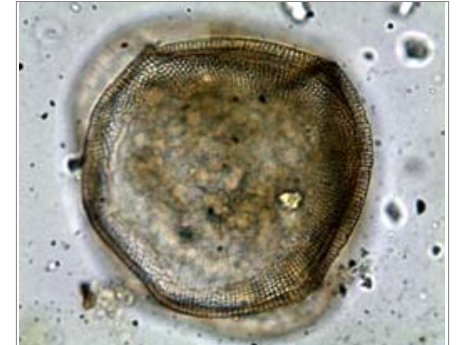

3

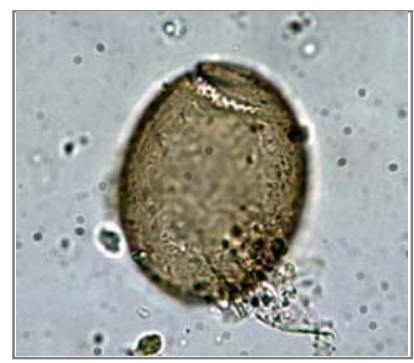

6

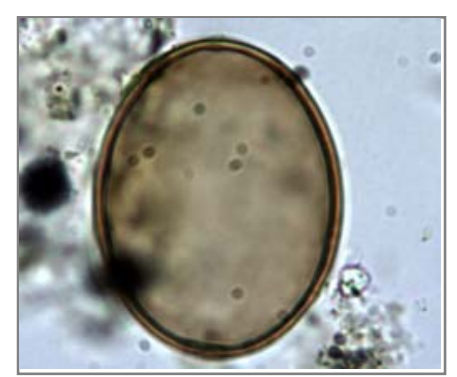

9

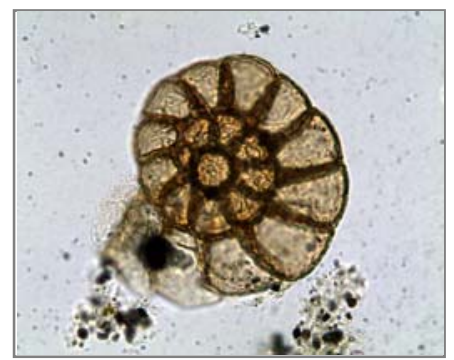

12

Plate 7 - Fig. 1, Tasmanites $105 \mu \mathrm{m}$, 149-31-2A, K56/4; Fig. 2-3, Tasmanites 125 $\mu \mathrm{m}, 186-13-2 \mathrm{~A}$, V34/1; Fig 4 Beringiella sp, $40 \mu \mathrm{m}, 186-14-3 \mathrm{~A}, \mathrm{~K} 52 / 4$; Fig. 5, Beringiella sp, $50 \mu \mathrm{m}, 901-28-1 \mathrm{~A}$, N55; Fig. 6-7, Beringiella sp, $55 \mu \mathrm{m}, 186-22-3 \mathrm{~B}$, U46/2; Fig. 8, Beringiella sp, $55 \mu \mathrm{m}, 901-27-3 \mathrm{~B}$, J49/3; Fig. 9, Beringiella sp, $55 \mu \mathrm{m}, 901-22-2 \mathrm{~B}$, O43/3; Fig. 10-11, Beringiella sp, $50 \mu \mathrm{m}, 901-5-2 B, H 45 / 2$; Fig. 12, Foraminifera Lining, $100 \mu \mathrm{m}, 186 / 21-3 \mathrm{~B} \times 41 / 1$ 


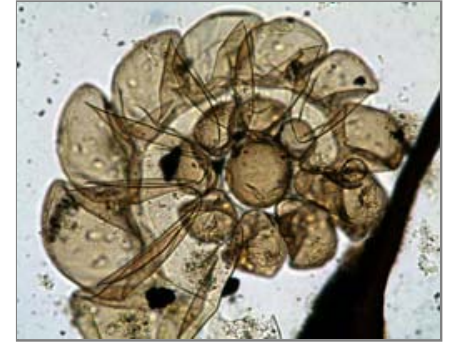

1

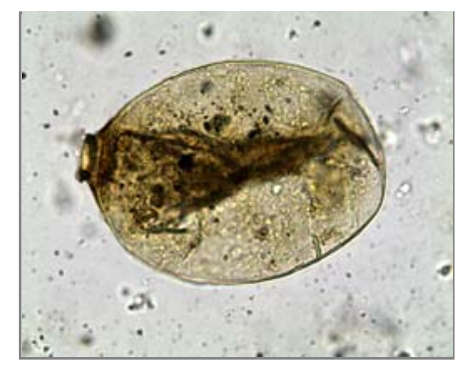

4

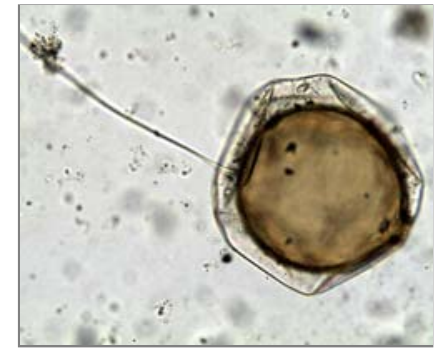

7

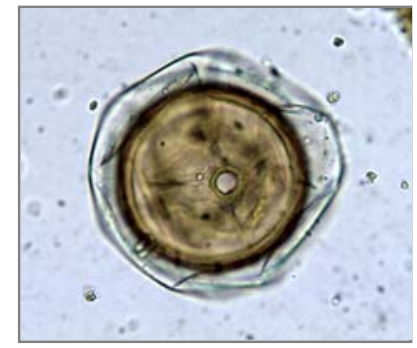

10

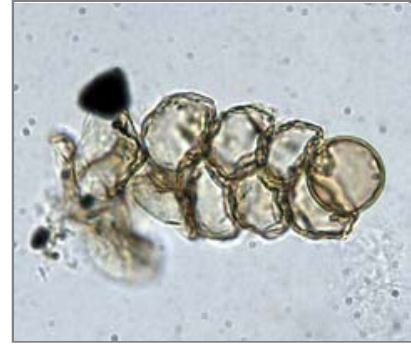

2

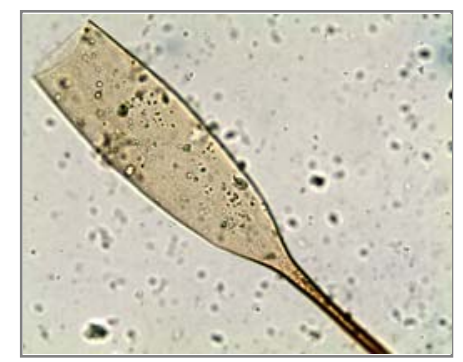

5

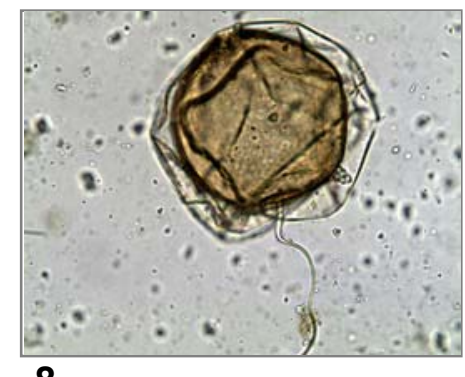

8

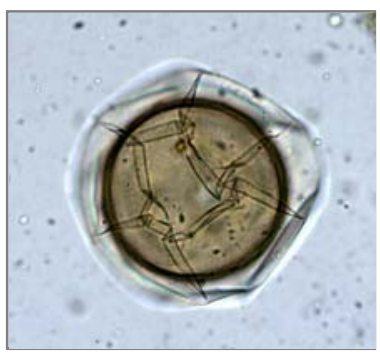

11

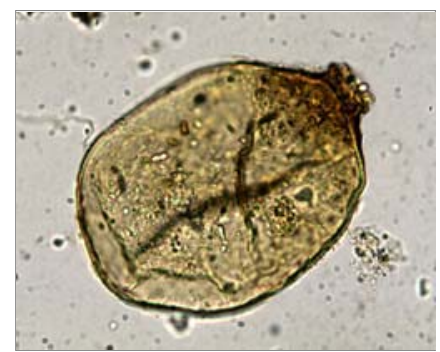

3

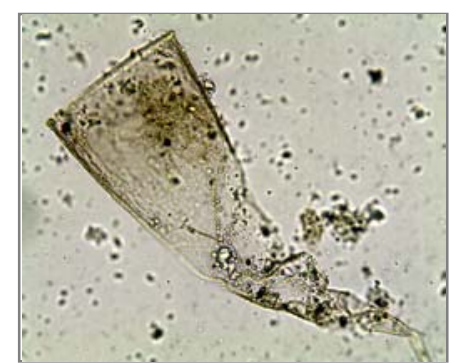

6
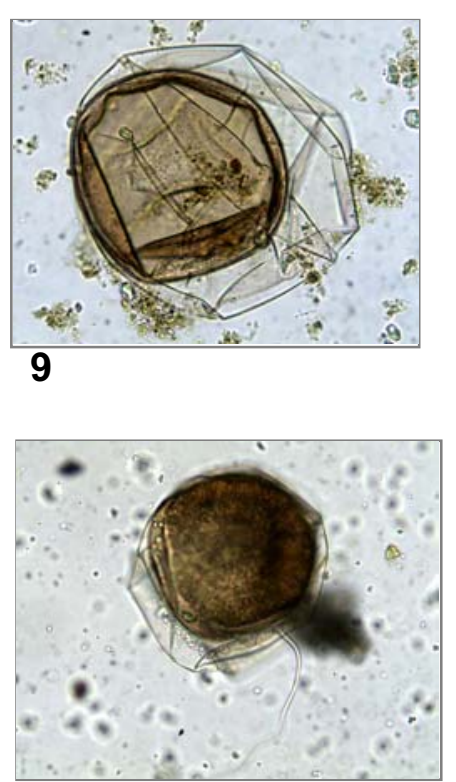

12

Plate 8 - Fig. 1, Foraminifera linings, 300+ $\mu \mathrm{m}$, 901-52B, Z40/2; Fig. 2, Foraminifera linings, $75 \mu \mathrm{m}, 186-21-3 \mathrm{~B}, \mathrm{~W} 40 / 3$; Fig. 3, Tintinnid cysts $100 \mu \mathrm{m}, 901-26-3 \mathrm{~B}, \mathrm{Q} 30 / 1$; Fig. 4, Tintinnid cysts $100 \mu \mathrm{m}, 186-16-2 A$ W42; Fig. 5, Tintinnid loricae, 250+ $\mu \mathrm{m}, 901-34-3 \mathrm{~A}$, W33; Fig. 6, Tintinnid loricae, 300+ $\mu \mathrm{m}, 186-17-3 \mathrm{~A}, \mathrm{C} 48 / 1$; Fig. 7, Zooplankton sp, (size not including "tail" for this species) $160 \mu \mathrm{m}, 186-18-3 \mathrm{~A}$ F43/4; Fig. 8, Zooplankton sp, $150 \mu \mathrm{m}, 149-31-2 \mathrm{~A}$, G56/2; Fig. 9, Zooplankton sp, $175 \mu \mathrm{m}, 186-22-2 \mathrm{~B}$, E47/2; Fig. 1011, Zooplankton sp, $155 \mu \mathrm{m}, 186-18-1 \mathrm{~A}, \mathrm{P} 44 / 1$; Fig. 12, Zooplankton sp, $150 \mu \mathrm{m}, 901-$ 28-1A, P52 


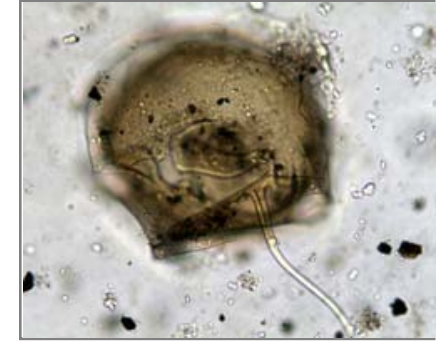

1

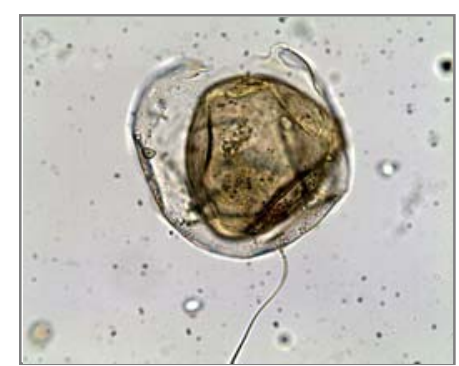

4

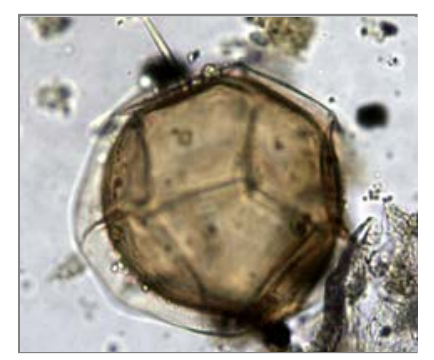

7

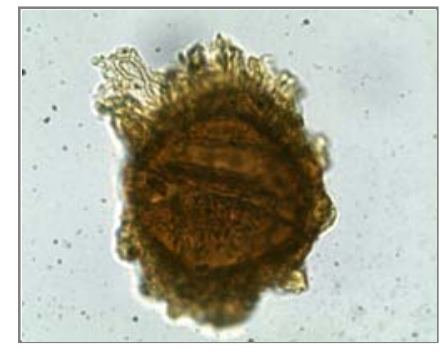

10

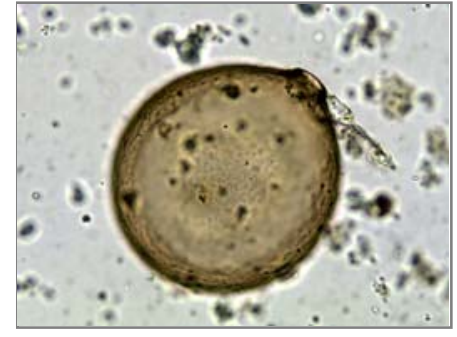

2

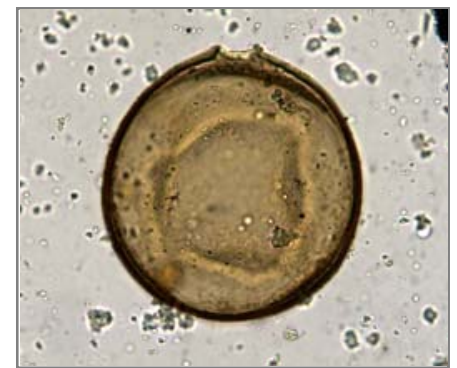

5

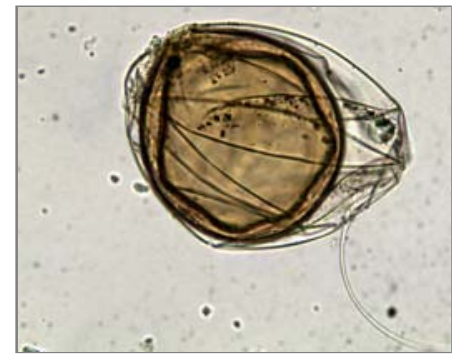

8

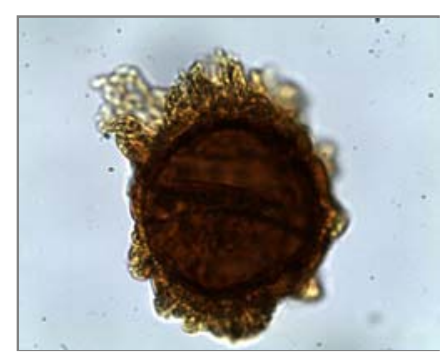

11

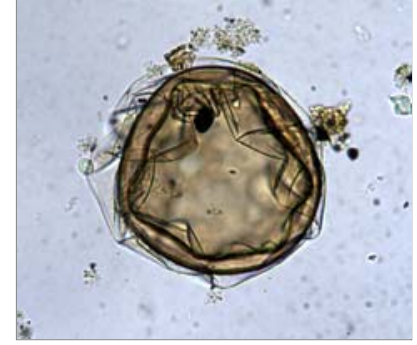

3

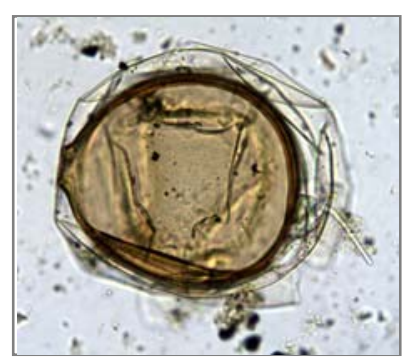

6

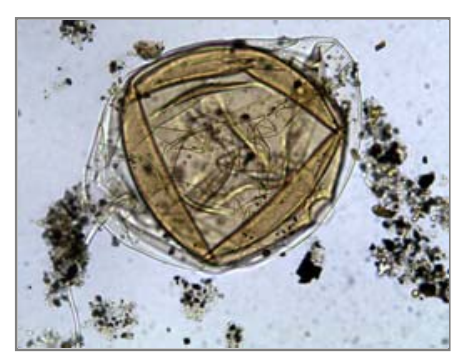

9

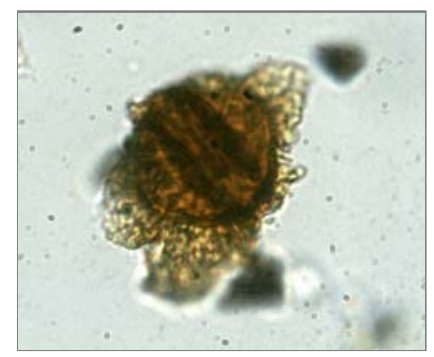

12

Plate 9 - Fig. 1, Zooplankton sp, (size not including "tail" for this species) $175 \mu \mathrm{m}$, 186-18-1,3A, Y29/2; Fig. 2, Zooplankton sp, $125 \mu \mathrm{m}, 186-14-1 \mathrm{~A}$, U45/1; Fig. 3, Zooplankton sp, $150 \mu \mathrm{m}, 901-22-2$ T43; Fig. 4, Zooplankton sp, $175 \mu \mathrm{m}, 186-26-3 \mathrm{~A}$ Q38; Fig. 5, Zooplankton sp, $150 \mu \mathrm{m}, 186-17-1 \mathrm{~A}$, Y44; Fig. 6, Zooplankton sp, $175 \mu \mathrm{m}, 901-$ 22-2 X31; Fig. 7, Zooplankton sp, $160 \mu \mathrm{m}, 901-23-3 \mathrm{~A}$ R49/4; Fig. 8, Zooplankton sp, 200 $\mu \mathrm{m}$, 186-14-1B, V41/2; Fig. 9, Zooplankton sp, $160 \mu \mathrm{m}, 901-27-4 \mathrm{~A}$, W47/1; Fig. 10-11, Turbiosphaera filosa, $50 \mu \mathrm{m}, 901-27-2 \mathrm{~B}, \mathrm{P} 42$; Fig. 12, Turbiosphaera filosa, $35 \mu \mathrm{m}, 186-$ 28-2A Q50 


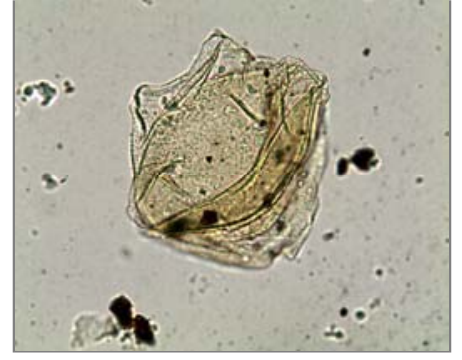

1

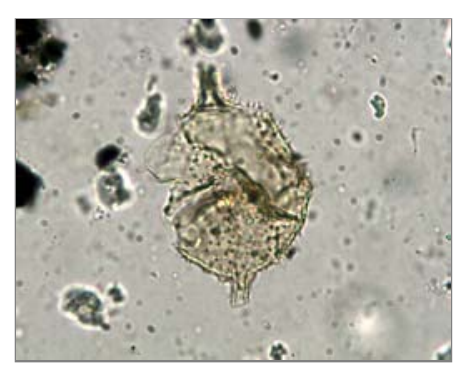

4

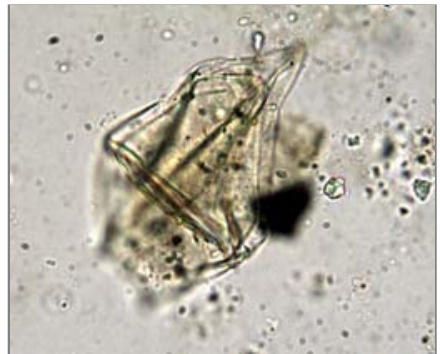

7

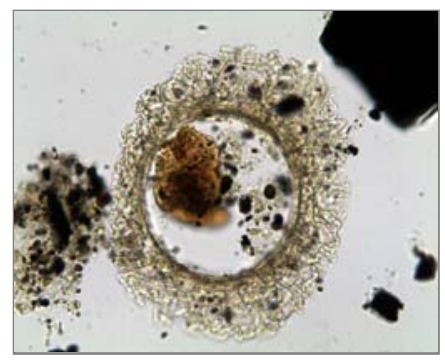

10

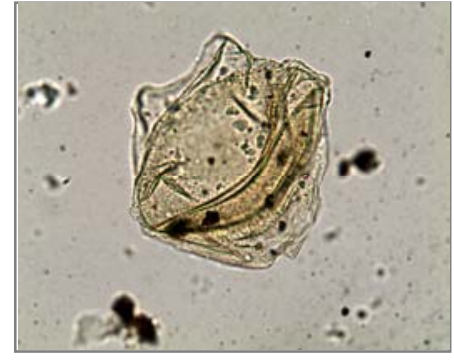

2

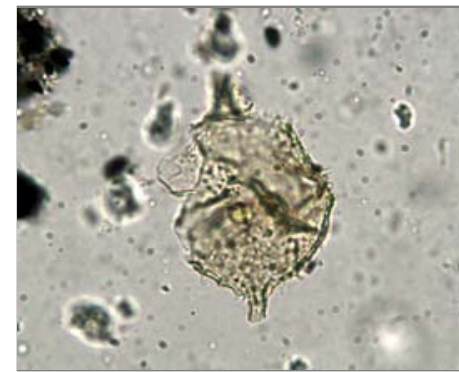

5

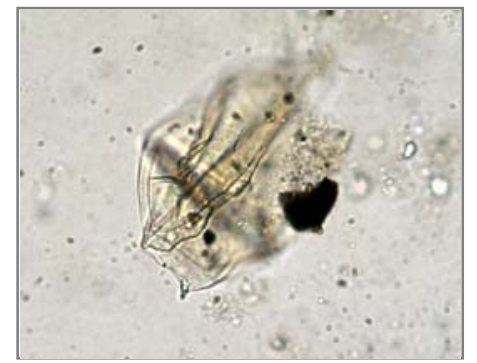

8

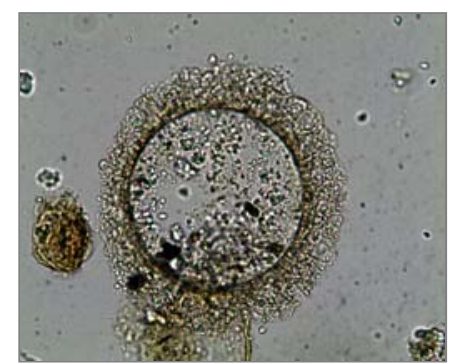

11

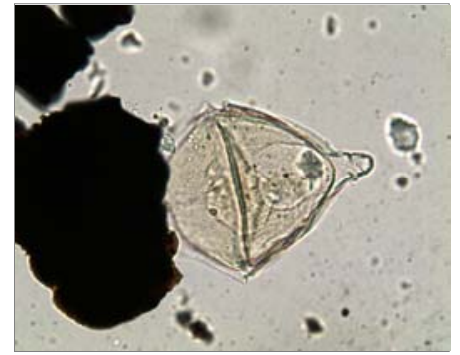

3

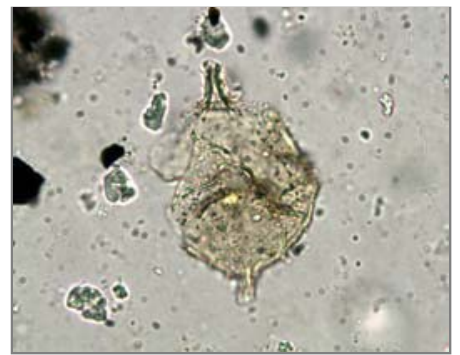

6

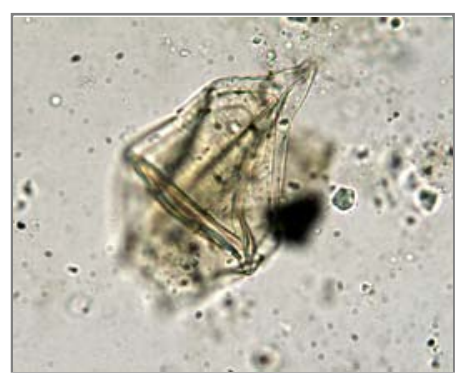

9

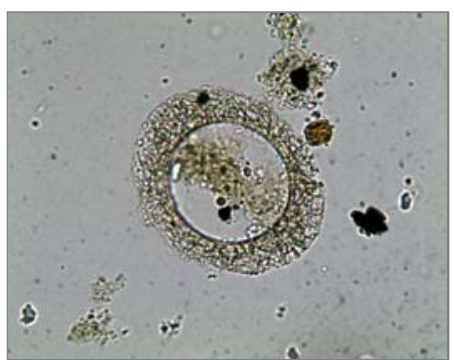

12

Plate 10 - Fig. 1-2, Deflandrea sp, $90 \mu \mathrm{m}, 149-35-2 A$, Y47; Fig. 3, Alterbidinium asymmetricum $100 \mu \mathrm{m}, 149-35-2 \mathrm{~A}$, O32. Fig. 4-6, Spinodinium sp, $75 \mu \mathrm{m}, 149-36-2 \mathrm{~B}$, Q39/4; Fig. 7-9, Alterbidinium asymmetricum $80 \mu \mathrm{m}$, 186-27-1B, N50; Fig. 10, Egg case, $115 \mu \mathrm{m}, 901-27-4 \mathrm{~A}$, S39/4; Fig. 11, Egg case, $125 \mu \mathrm{m}$, 901-23-2A, N34; Fig. 12, Egg case, $125 \mu \mathrm{m}, 901-23-2 \mathrm{~A}$, D33/3 


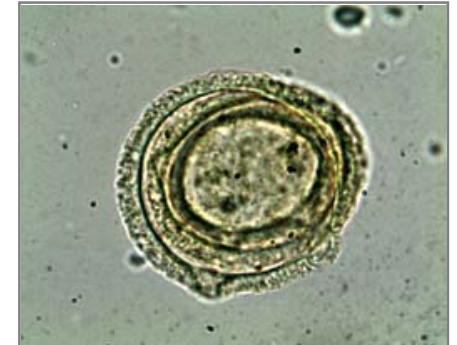

1

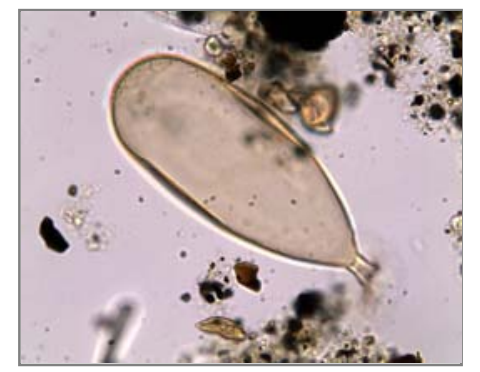

4

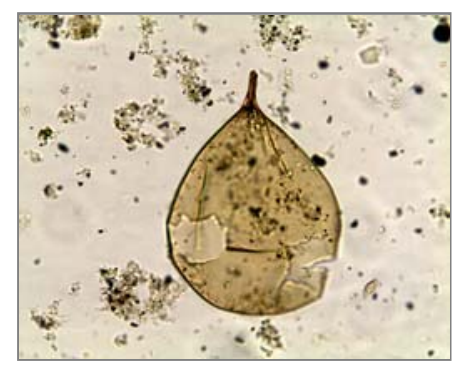

7

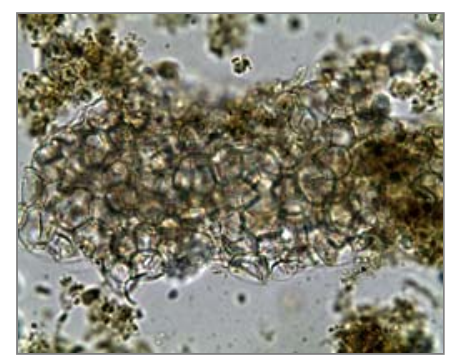

10

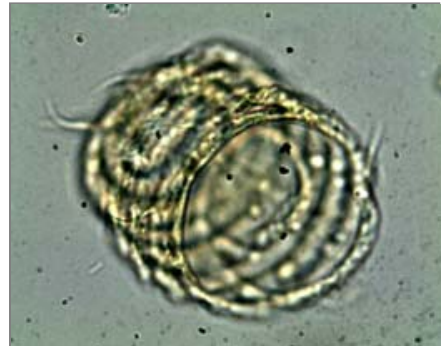

2

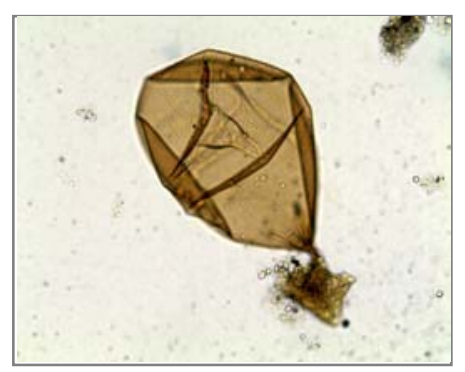

5

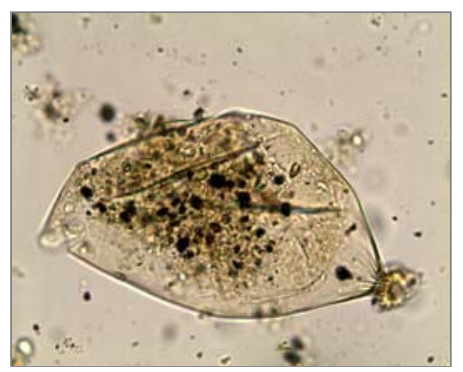

8

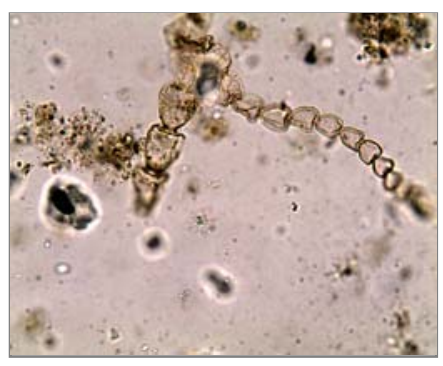

11

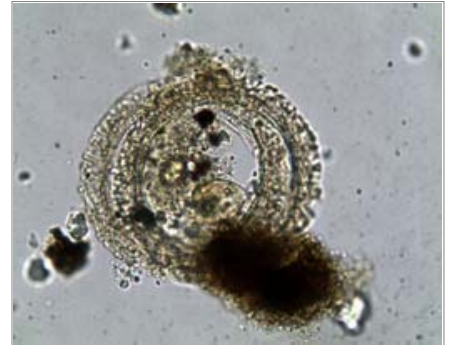

3

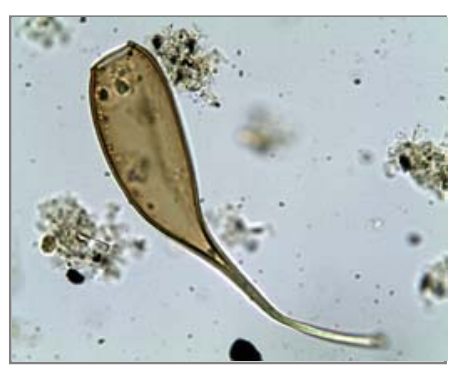

6

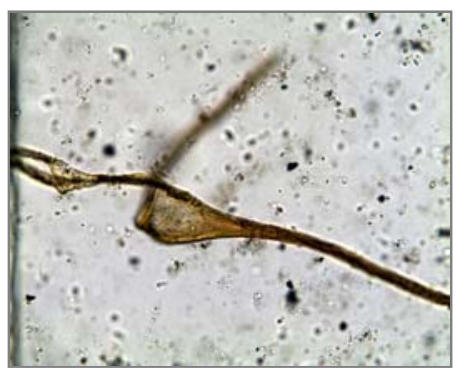

9

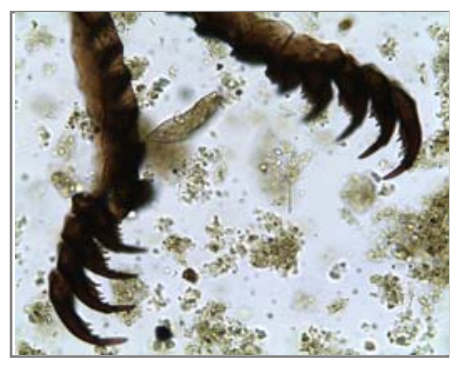

12

Plate 11 - Fig. 1, Unknown, $35 \mu \mathrm{m}, 901-33-2 A$, L47; Fig. 2, Unknown, $45 \mu \mathrm{m}, 901-$ 33-1A S47/4; Fig. 3, Unknown $75 \mu \mathrm{m}$, 901-23-1A S50; Fig. 4, Egg Case, $250 \mu \mathrm{m}, 186-$ 21-3B, U34/3; Fig. 5, Egg Case, $165 \mu \mathrm{m}, 186-9-3 B$, E44; Fig. 6, Unknown, $75 \mu \mathrm{m}, 901-$ 22-4A, Q48/4; Fig. 7, Egg Case, $175 \mu \mathrm{m}, 901-22-2 B$, Q31/4; Fig. 8, Egg Case $150 \mu \mathrm{m}$, 901-22-2, C31; Fig. 9, Unknown, $65 \mu \mathrm{m}, 186-18-1 \mathrm{~A}, \mathrm{D} 28 / 2$; Fig. 10, Algal Group, 18622-3B, L48/3; Fig. 11, Algal Chain, 901-11-1B C39/1; Fig. 12, Insect Parts, $300+\mu \mathrm{m}$, 186-22-1B, F28/3 

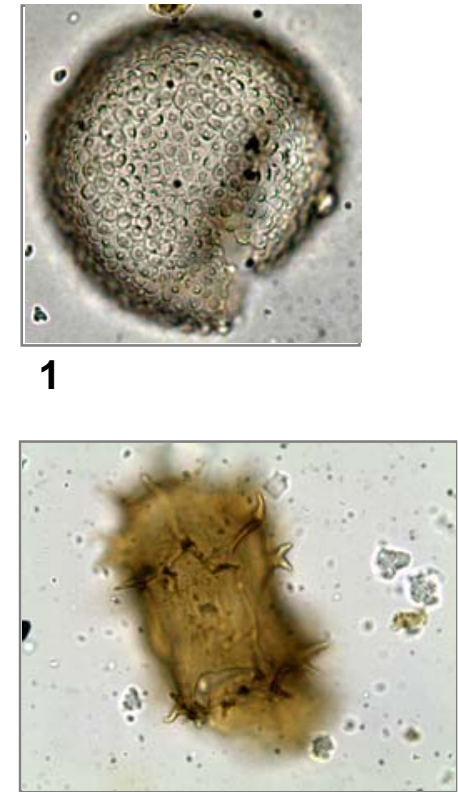

4

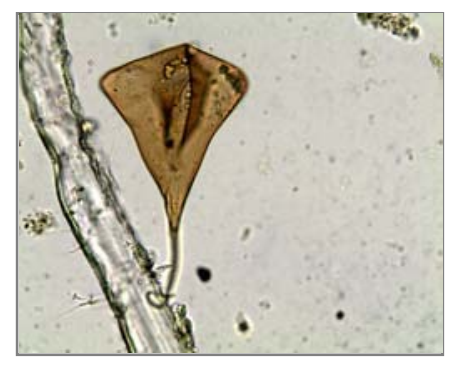

7

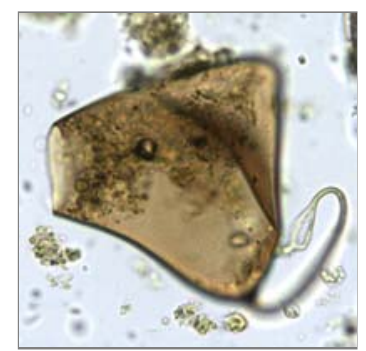

10

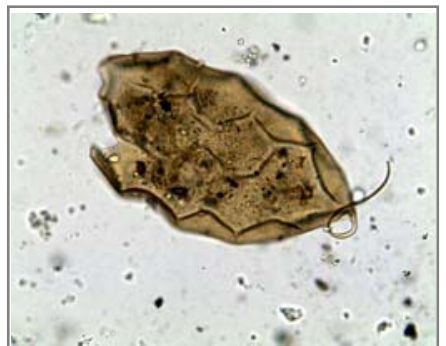

2

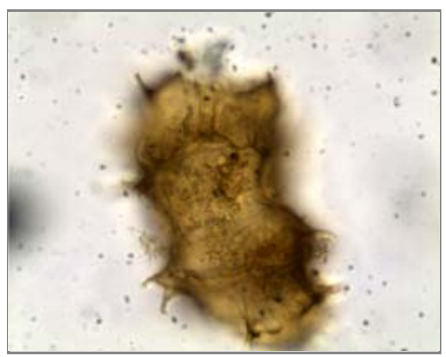

5

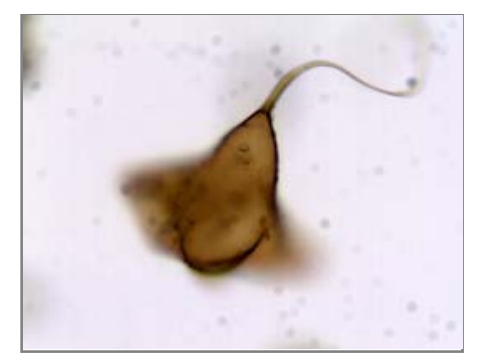

8

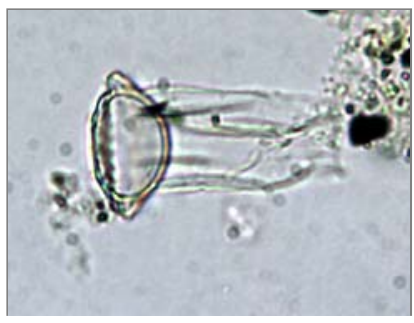

11



3

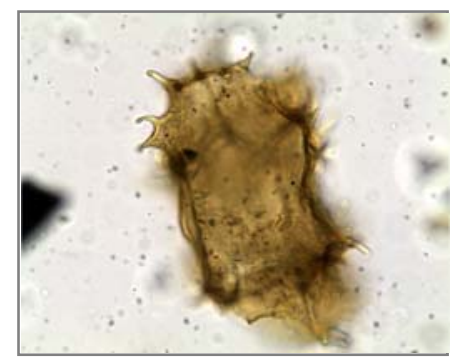

6

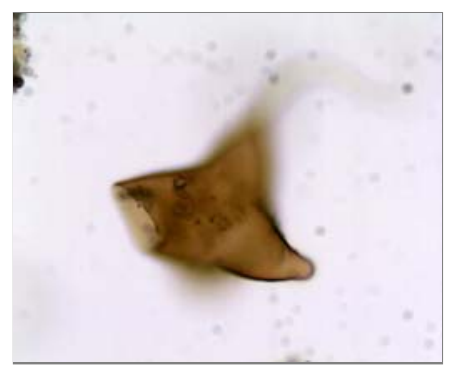

9

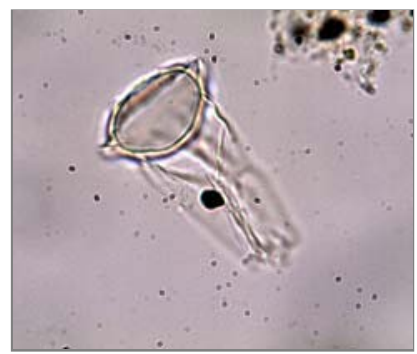

12

Plate 12 - Fig. 1, Egg Case, $100 \mu \mathrm{m}, 901-28-3 A$, B40/2; Fig. 2, Egg Case, $200 \mu \mathrm{m}$, 186-16-2A, X49/3; Fig. 3, Egg Case $160 \mu \mathrm{m}, 901-11-3 \mathrm{~A}$, W41/1; Fig. 4-6, Egg Case 125 $\mu \mathrm{m}$, 901-33-3A, R50/3; Fig. 7, Egg Case, $150 \mu \mathrm{m}$, 901-24-2B, D36; Fig. 8-9, Egg Case, $145 \mu \mathrm{m}, 186-22-3 \mathrm{~B}, \mathrm{Y} 55 / 2$; Fig. 10, Egg Case, $125 \mu \mathrm{m}, 186-22-1 \mathrm{~B}, \mathrm{~S} 32$; Fig. 11, Unknown, $40 \mu \mathrm{m}, 186-21-2 \mathrm{~B}$, W39/2; Fig. 12, Unknown, $35 \mu \mathrm{m}, 186-21-3 \mathrm{~B}, \mathrm{Y} 38 / 4$ 


\section{CHAPTER 4 METHOD AND RESULTS - GRAIN SIZE}

\subsection{Introduction}

Sediment on the floor of Prydz Bay has been either transported by ice or currents from the Antarctic continent onto the continental shelf and slope or in the case of biogenic sediment produced from the surface waters of the bay and settled to the sea floor. Some sediment has also been reworked by strong currents or redeposited by sediment gravity flows. Grain size analysis was carried out on splits of samples also processed for palynology to help understand how the sediment and the included palynomorphs reached the various sample sites.

\subsection{Method}

Each sample was dried, weighed and placed in a beaker with $0.1 \%$ calgon solution and disaggregated in an ultrasonic tank for half an hour. It was then split into sand and mud fractions by wet sieving through a $62 \mu \mathrm{m}$ nylon mesh. The fine fraction was washed into a centrifuge bucket, and then centrifuged, decanted, and transferred into a labeled beaker. The coarse fraction was washed off the nylon mesh into another labeled beaker and placed with the fine fraction beaker in an oven for drying at $40^{\circ} \mathrm{C}$.

The coarse fraction was dry sieved at $1 / 2 \varnothing$ intervals from -4.0 to $5.0 \varnothing$.

Contamination of the sieve screens was avoided by cleaning each screen with a brush and compressed air before each sample was sieved. The sieves were nested with the coarsest at the top and the pan at the bottom and the lid fastened tightly. A timer was set for 18 minutes on a shaker to commence the sieving which alternated between intermittent and micro mode. After sieving each size fraction was weighed and recorded.

Two grams of the dried fine fraction were split off, weighed and analysed by a Sedigraph 5100 particle size analyser to determine the grain size distribution of the fine fraction. The results were then merged with the coarse fraction results and 
entered into the VUWSIZE program to produce statistics and histograms for each sample. The weight of sample sizes was variable with 33 out of 58 samples weighing $<10 \mathrm{~g}$ and only one sample $>20 \mathrm{~g}$. As mentioned in Chapter 3 , four samples could not be included in the grain size analysis from the mid shelf area (GC901-24, GC901-25, GC901-26, GC186-13) because they did not contain sufficient sediment for analysis after the drying process.

\subsection{Results}

Best results are obtained from the method described here for samples of more than $10 \mathrm{~g}$ (Barrett \& Anderson, 2000). Just over half of the samples were below this amount, but results obtained here compare well to other grain size analysis carried out within Prydz Bay, as can be seen by comparison with the data provided by Harris et al. (1998) (fig 4.1a).

The VUWSIZE program collates the output data, providing one table of frequency percent data and another of basic statistics (key percentiles, moment measures, graphic measures) and percent gravel, sand, silt and clay (Appendix B). The program also depicts histograms (phi $v$ frequency) for each sample and examples are shown in fig 4.2. Silt and clay proportions were combined to obtain mud percent and contour maps were compiled on GIS Arcview as described in Chapter 3. The mud percent data were combined with data from Harris et al. (1998) to give a more complete picture of the distribution of mud in the bay. A contour map was also compiled for percent gravel using data from this study (fig 4.1b). Other Arcview maps show possible lithology (fig 4.3) and depth for each sample (fig 4.4) and individual maps for mud, sand and gravel proportions were compiled (fig $4.5 \mathrm{a}, \mathrm{b}, \mathrm{c}$ ). A table was compiled showing sample numbers, depth and raw count for total palynomorphs and separated into the four main geographic areas (Table 4.1). Graphs were compiled (fig 4.6a, b, c, d) showing pollen count vs mud \%, dinocyst vs mud $\%$, pollen vs gravel $\%$ and dinocyst vs gravel $\%$. 


\section{Table 4.1}

\section{Prydz Channel Fan}

Sample Depth Gravel Sand Mud Acri- Holocene Egg Prasino- Foram- Red Zoo- Insect Un- Reworked Pollen Total $\begin{array}{lllllll}\text { Number } & (\mathrm{m}) & (\%) & (\%) & (\%) \text { tarchs dinocysts cases phytes inifera algae plankton parts knowns dinocysts }\end{array}$

\begin{tabular}{|c|c|c|c|c|c|c|c|c|c|c|c|c|c|c|c|c|}
\hline & & (10) & (10) & (i) & & & & & Hera & (you & & & & & & \\
\hline $149-14$ & 849 & 3.5 & 58.0 & 38.5 & 0 & 0 & 0 & 0 & 0 & 0 & 0 & 0 & 0 & 0 & 54 & 54 \\
\hline $149-16$ & 1,960 & 0.5 & 7.3 & 92.3 & 0 & 0 & 0 & 0 & 0 & 0 & 0 & 1 & 0 & 0 & 4 & 5 \\
\hline $149-18$ & 1,170 & 12.6 & 37.3 & 50.1 & 1 & 0 & 0 & 0 & 0 & 0 & 0 & 0 & 0 & 1 & 29 & 31 \\
\hline $149-19$ & 765 & 10.3 & 71.6 & 18.1 & 1 & 0 & 0 & 0 & 0 & 0 & 0 & 0 & 0 & 5 & 31 & 37 \\
\hline $149-22$ & 1,450 & 0.5 & 46.3 & 53.1 & 0 & 0 & 0 & 0 & 0 & 0 & 0 & 0 & 0 & 0 & 33 & 33 \\
\hline $149-23$ & 1,884 & 2.3 & 30.4 & 67.2 & 0 & 0 & 0 & 0 & 0 & 0 & 0 & 0 & 0 & 0 & 24 & 24 \\
\hline $149-24$ & 2,535 & 0.0 & 4.6 & 95.4 & 0 & 0 & 0 & 0 & 0 & 0 & 0 & 0 & 0 & 0 & 3 & 3 \\
\hline $149-25$ & 2,010 & 0.0 & 10.2 & 89.8 & 0 & 0 & 0 & 0 & 0 & 0 & 0 & 0 & 0 & 0 & 0 & 0 \\
\hline $149-27$ & 1,200 & 1.8 & 60.2 & 38.0 & 1 & 0 & 0 & 0 & 0 & 0 & 0 & 0 & 0 & 1 & 397 & 399 \\
\hline $149-36$ & 2,105 & 1.4 & 12.6 & 86.0 & 0 & 0 & 0 & 0 & 0 & 0 & 1 & 0 & 0 & 4 & 15 & 20 \\
\hline $186-29$ & 1,230 & 6.9 & 40.4 & 52.8 & 3 & 0 & 1 & 0 & 8 & 2 & 0 & 0 & 0 & 3 & 41 & 58 \\
\hline $186-31$ & 1,625 & 0.0 & 3.1 & 96.9 & 0 & 0 & 0 & 0 & 0 & 0 & 0 & 0 & 0 & 1 & 17 & 18 \\
\hline $186-32$ & 1,830 & 0.9 & 9.2 & 89.9 & 0 & 1 & 0 & 0 & 0 & 0 & 0 & 0 & 0 & 1 & 13 & 15 \\
\hline 901-09 & 1,879 & 12.8 & 82.5 & 4.7 & 2 & 0 & 0 & 2 & 0 & 1 & 0 & 0 & 0 & 0 & 16 & 21 \\
\hline $901-10$ & 1,257 & 31.5 & 63.6 & 4.9 & 0 & 0 & 0 & 0 & 1 & 0 & 0 & 0 & 0 & 0 & 5 & 6 \\
\hline $901-13$ & 880 & 0.8 & 11.3 & 87.9 & 1 & 0 & 2 & 0 & 3 & 0 & 0 & 1 & 1 & 0 & 2 & 10 \\
\hline
\end{tabular}




\begin{tabular}{|c|c|c|c|c|c|c|c|c|c|c|c|c|c|c|c|c|}
\hline $\begin{array}{l}\text { Sample } \\
\text { Number }\end{array}$ & $\begin{array}{c}\text { Depth } \\
(\mathrm{m})\end{array}$ & $\begin{array}{c}\text { Gravel } \\
(\%) \\
\end{array}$ & $\begin{array}{c}\text { Sand } \\
(\%)\end{array}$ & $\begin{array}{l}\text { Mud } \\
(\%) \\
\end{array}$ & $\begin{array}{c}\text { Acri- } \\
\text { tarchs }\end{array}$ & $\begin{array}{l}\text { Holocene } \\
\text { dinocysts }\end{array}$ & $\begin{array}{c}\text { Egg } \\
\text { cases }\end{array}$ & $\begin{array}{c}\text { Prasino- } \\
\text { phytes }\end{array}$ & $\begin{array}{l}\text { Foram- } \\
\text { inifera }\end{array}$ & $\begin{array}{c}\text { Red } \\
\text { algae }\end{array}$ & $\begin{array}{c}\text { Zoo- } \\
\text { plankton }\end{array}$ & $\begin{array}{c}\text { Insect } \\
\text { parts }\end{array}$ & $\begin{array}{c}\text { Un- } \\
\text { knowns }\end{array}$ & $\begin{array}{l}\text { Reworked } \\
\text { dinocysts }\end{array}$ & Pollen & Total \\
\hline \multicolumn{17}{|c|}{ Fram Bank } \\
\hline $149-06$ & 805 & 1.4 & 89.9 & 8.7 & 0 & 0 & 0 & 4 & 0 & 0 & 3 & 0 & 0 & 0 & 382 & 389 \\
\hline $149-37$ & 168 & 2.8 & 55.9 & 41.4 & 0 & 0 & 10 & 6 & 124 & 20 & 43 & 7 & 1 & 0 & 2 & 213 \\
\hline 901-05 & 320 & 5.7 & 54.1 & 40.2 & 2 & 0 & 2 & 1 & 244 & 4 & 30 & 21 & 6 & 1 & 4 & 315 \\
\hline $901-11$ & 402 & 0.0 & 62.2 & 37.9 & 0 & 0 & 2 & 3 & 120 & 5 & 37 & 30 & 4 & 1 & 57 & 259 \\
\hline $901-14$ & 430 & 31.7 & 38.4 & 29.9 & 0 & 1 & 4 & 0 & 60 & 0 & 5 & 16 & 0 & 0 & 14 & 100 \\
\hline $901-33$ & 376 & 6.5 & 75.3 & 18.2 & 38 & 3 & 29 & 3 & 344 & 4 & 235 & 18 & 8 & 0 & 2 & 684 \\
\hline \multicolumn{17}{|c|}{ Northern Prydz Channel } \\
\hline $186-26$ & 390 & 12.5 & 64.7 & 22.8 & 1 & 0 & 10 & 1 & 115 & 6 & 150 & 3 & 0 & 0 & 4 & 290 \\
\hline $186-27$ & 436 & 0.0 & 36.4 & 63.6 & 1 & 1 & 1 & 0 & 11 & 3 & 9 & 4 & 0 & 5 & 63 & 98 \\
\hline $901-15$ & 480 & 8.4 & 61.2 & 30.4 & 0 & 0 & 2 & 0 & 35 & 0 & 16 & 5 & 2 & 0 & 78 & 138 \\
\hline \multicolumn{17}{|c|}{ Four Ladies Bank } \\
\hline $186-28$ & 338 & 15.7 & 36.5 & 47.8 & 0 & 0 & 1 & 1 & 4 & 6 & 25 & 9 & 0 & 7 & 55 & 108 \\
\hline $901-18$ & 320 & 2.9 & 47.0 & 50.1 & 1 & 0 & 5 & 5 & 17 & 12 & 11 & 6 & 1 & 2 & 88 & 148 \\
\hline $901-20$ & 318 & 30.5 & 42.2 & 27.4 & 1 & 1 & 2 & 1 & 9 & 4 & 24 & 1 & 0 & 0 & 70 & 113 \\
\hline
\end{tabular}




\begin{tabular}{|c|c|c|c|c|c|c|c|c|c|c|c|c|c|c|c|c|}
\hline $\begin{array}{l}\text { Sample } \\
\text { Number }\end{array}$ & $\begin{array}{l}\text { Depth } \\
(\mathrm{m})\end{array}$ & $\begin{array}{c}\text { Gravel } \\
(\%) \\
\end{array}$ & $\begin{array}{c}\text { Sand } \\
(\%)\end{array}$ & $\begin{array}{c}\text { Mud } \\
(\%) \\
\end{array}$ & $\begin{array}{c}\text { Acri- } \\
\text { tarchs }\end{array}$ & $\begin{array}{l}\text { Holocene } \\
\text { dinocysts }\end{array}$ & $\begin{array}{c}\text { Egg } \\
\text { cases }\end{array}$ & $\begin{array}{c}\text { Prasino- } \\
\text { phytes }\end{array}$ & $\begin{array}{l}\text { Foram- } \\
\text { inifera }\end{array}$ & $\begin{array}{c}\text { Red } \\
\text { algae }\end{array}$ & $\begin{array}{c}\text { Zoo- } \\
\text { plankton }\end{array}$ & $\begin{array}{c}\text { Insect } \\
\text { parts }\end{array}$ & $\begin{array}{c}\text { Un- } \\
\text { knowns }\end{array}$ & $\begin{array}{l}\text { Reworked } \\
\text { dinocysts }\end{array}$ & Pollen & Total \\
\hline $186-11$ & 655 & $\mathrm{n} / \mathrm{a}$ & $\mathrm{n} / \mathrm{a}$ & $\mathrm{n} / \mathrm{a}$ & 6 & 0 & 9 & 1 & 50 & 15 & 62 & 6 & 2 & 0 & 69 & 220 \\
\hline $186-13$ & 678 & 8.6 & 19.2 & 72.2 & 40 & 20 & 17 & 39 & 47 & 11 & 193 & 26 & 4 & 0 & 2 & 399 \\
\hline $186-14$ & 690 & 0.4 & 52.3 & 47.3 & 5 & 1 & 14 & 9 & 196 & 26 & 265 & 28 & 3 & 0 & 1 & 548 \\
\hline $186-19$ & 775 & 0.0 & 4.3 & 95.7 & 0 & 0 & 7 & 8 & 78 & 11 & 133 & 25 & 1 & 0 & 10 & 273 \\
\hline $186-21$ & 570 & 0.0 & 11.8 & 88.2 & 12 & 0 & 11 & 45 & 39 & 9 & 62 & 13 & 2 & 0 & 14 & 207 \\
\hline $186-22$ & 660 & 1.4 & 42.8 & 55.8 & 17 & 77 & 48 & 8 & 296 & 91 & 378 & 66 & 6 & 0 & 27 & 1014 \\
\hline $901-22$ & 766 & 0.0 & 7.4 & 92.6 & 6 & 1 & 16 & 14 & 72 & 26 & 338 & 51 & 2 & 0 & 16 & 542 \\
\hline $901-23$ & 661 & 0.0 & 8.0 & 92.0 & 65 & 15 & 54 & 20 & 251 & 28 & 334 & 83 & 4 & 0 & 2 & 856 \\
\hline
\end{tabular}

\section{Coastal}

Sample Depth Gravel Sand Mud Acri- Holocene Egg Prasino- Foram- Red Zoo- Insect Un- Reworked Pollen Total

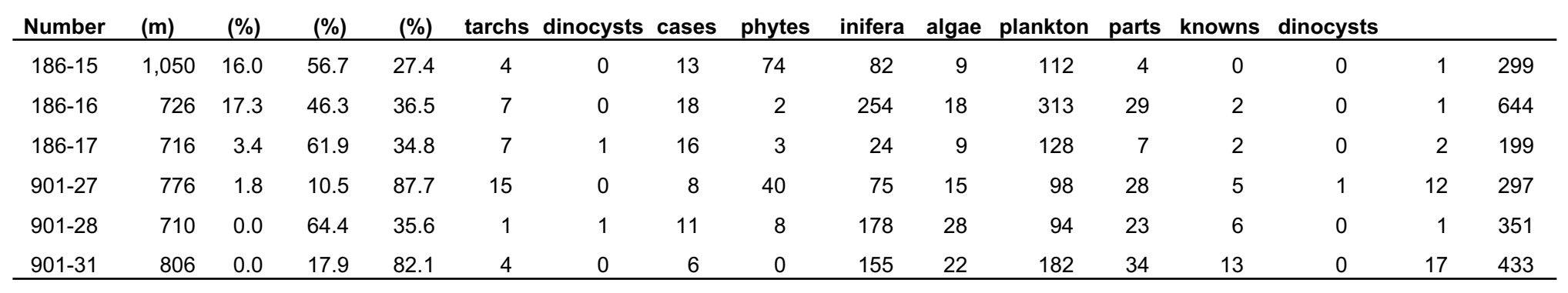

Table 4.1: Raw counts of total Prydz Bay palynomorphs and sample numbers, depths in meters and four main geographic areas of Prydz Channel Fan, North Shelf (split into Fram Bank, Northern Prydz Channel and Four Ladies Bank), Mid Shelf and Coastal. 


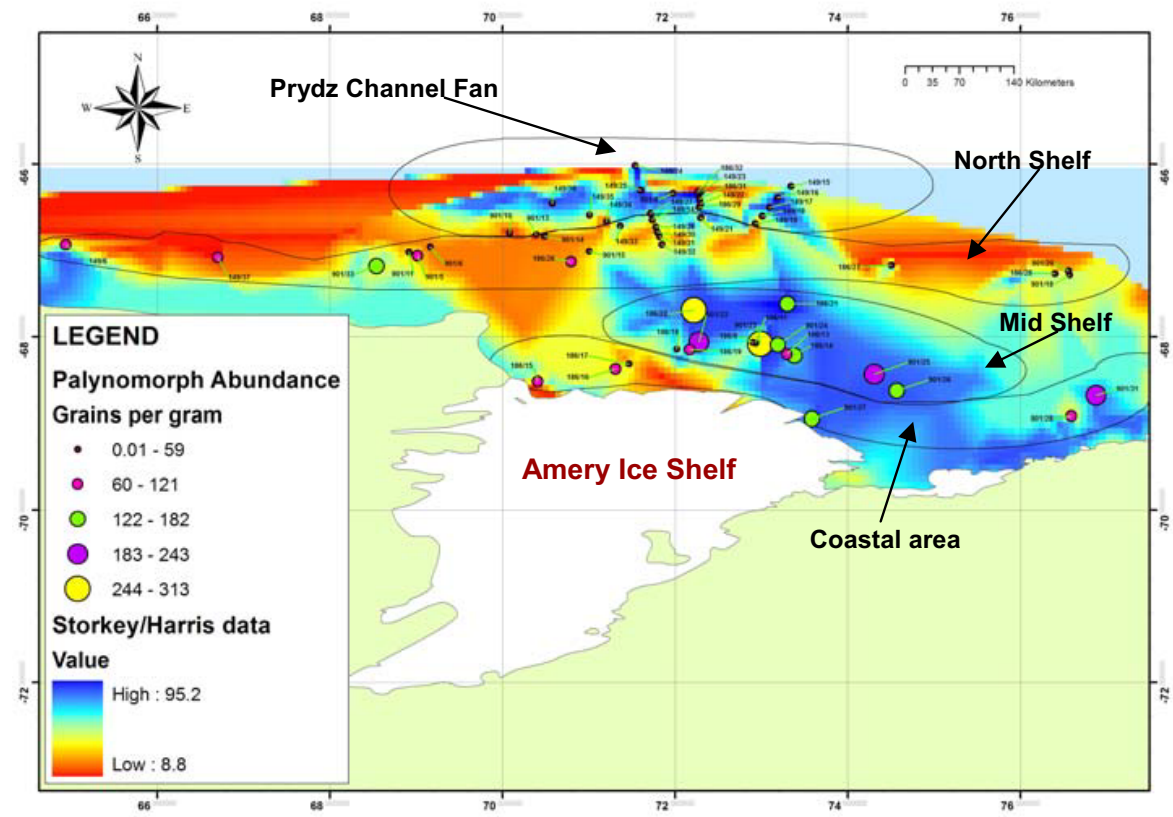

Fig. 4.1a: Combined mud \% compiled from grain size of mud proportions from Storkey (this study) and from mud proportions compiled by Harris et al (1998). Highest proportion of mud is blue, lowest is red. Sample numbers are shown with highest abundance as per legend.

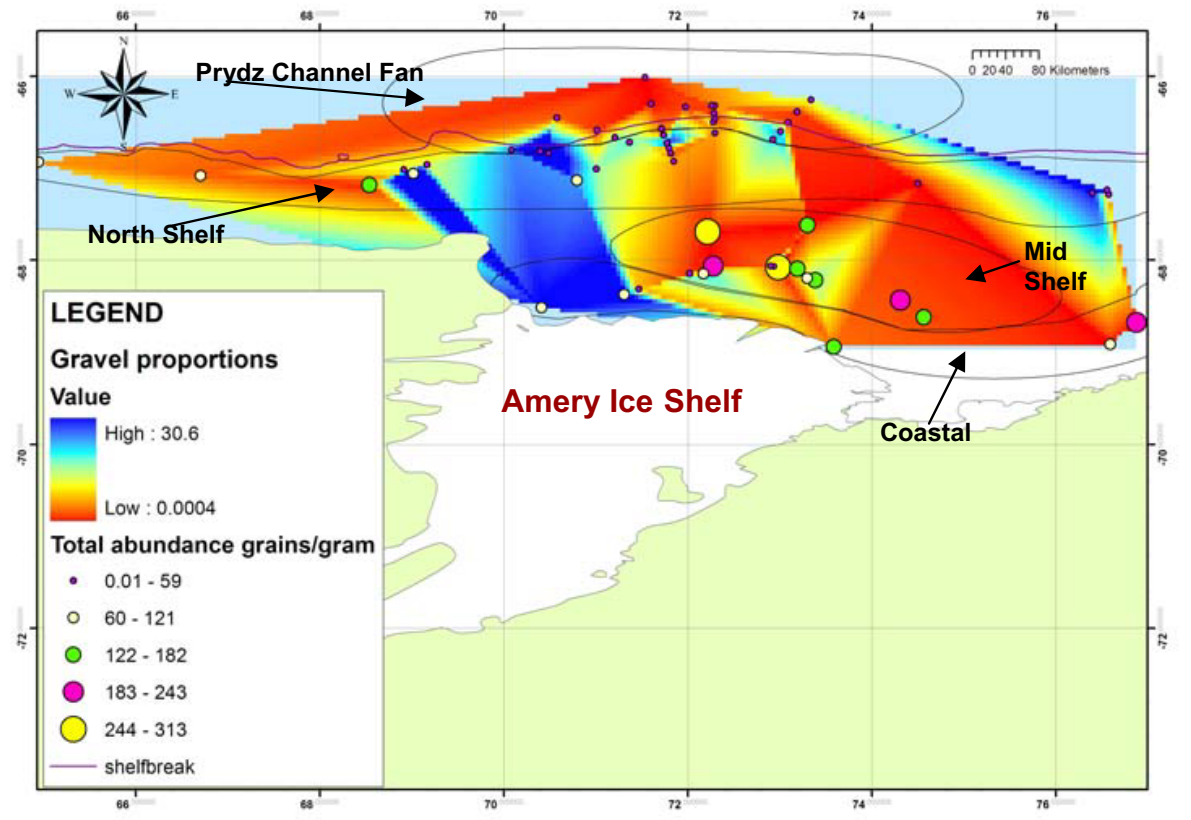

Fig. 4.1b: Contour map showing proportions for gravel, taken from Storkey grain size analysis (this study). Highest gravel proportions are blue as per legend. Geographic areas are shown with black lines encircling the different areas in both figures a \& b. Sample numbers are shown with highest abundance as per legend. 


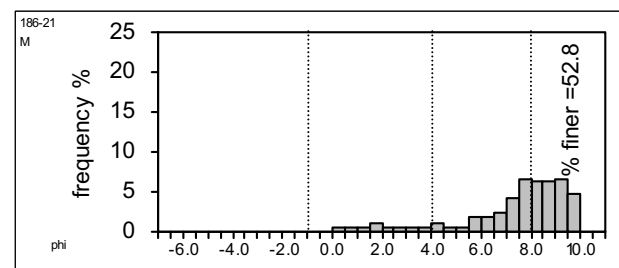

186/21 mud and Ice Rafted Debris just to the east of the Prydz Channel

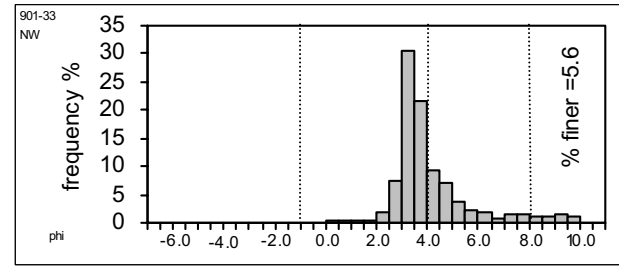

901/33 current swept sand on the Fram Bank

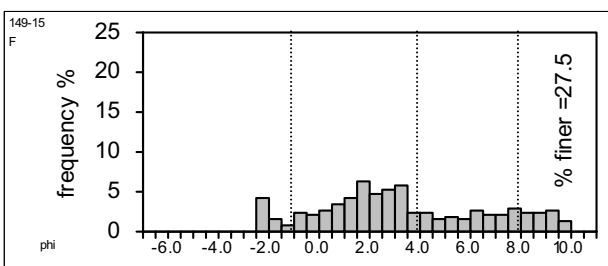

149/15 Sediment Gravity Flow on the Fan

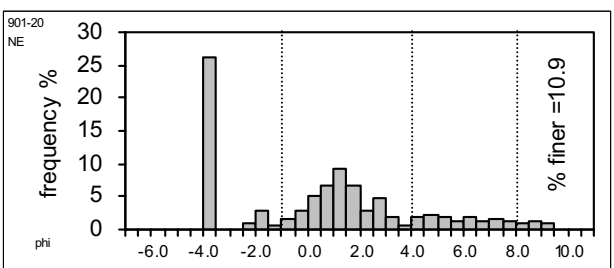

$901 / 20$ very sandy with pebbles and some mud on the Four Ladies Bank diamicton

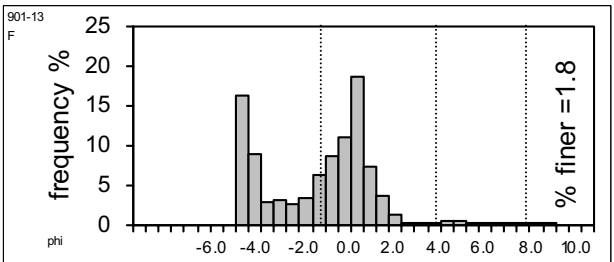

901/13 Current swept pebbles and Ice Rafted Debris on the Fan

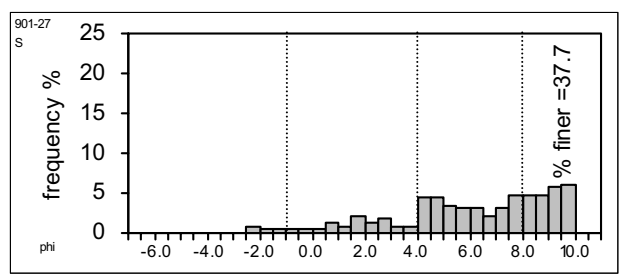

901/27 Ice Rafted Debris and mud in front of the Amery Ice Shelf

Fig. 4.2: Examples of histograms taken from the grain size analysis for this study and showing typical types of sediment from the surface cores in Prydz Bay. They illustrate the range of textures from diamicton and current swept sediment to Ice Rafted Debris and Sediment Gravity Flows. 


\subsection{Interpretation}

The overall grain size distribution shown in figures $4.5 \mathrm{a}, \mathrm{b}$ and $\mathrm{c}$, shows a clear link with the area and depth (fig 4.4) sampled within the embayment. In addition to the modern sediment flux the Prydz Bay area is greatly influenced by past glacial advances. Sediments within Prydz Bay have been eroded from the continent and deposited from glaciers as either directly from more extensive grounded ice, by meltout from the basal debris layer of a floating ice tongue, or carried offshore by bergs and sea ice (ice-rafted debris or IRD) (fig 4.3). The former two processes result in very poorly sorted sediment, ranging in size from clay to boulders, and termed diamicton (Hambrey et al. 1992). IRD is mainly medium to coarse sand with a little gravel, and is transported over the entire bay area and beyond into the Southern Ocean. The amount of such sediment is small though, being evident as the coarse fraction in mud deposited in quiet environments. Terrigenous mud is also derived from the continent through subglacial meltwater discharge or reworking of diamicton and settles in parts of the bay where current velocities are low e.g. less than $10 \mathrm{~cm} / \mathrm{sec}$. Diatomaceous mud is common in the bay also, the diatoms themselves being also largely of mud size. However, unlike mud, which circulates in suspension for days and weeks, they settle out within a day from surface waters as medium sand-sized pellets from grazing planktic crustacean organisms (Dunbar et al. 1989).

The sediments of Prydz Bay are in places locally winnowed and redeposited by currents where bottom velocities exceed around $20 \mathrm{~cm} / \mathrm{sec}$ (Hujhlstrom, 1935), leaving sorted sand, or mixed and redeposited by sediment gravity flows in areas with slopes of more than a degree or so (Pickering et al. 1989). Seismic geometries suggest that the latter process dominates the formation of the Prydz Channel Fan (O’Brien, 1994).

\subsection{Prydz Channel Fan}

Surface samples (901-13, 149-14, 149-19) on the Fan but close to the shelf edge, at depths of between 750-1,000 m (fig 4.4) contain some gravel 10-31\%, (fig 4.5c) and 


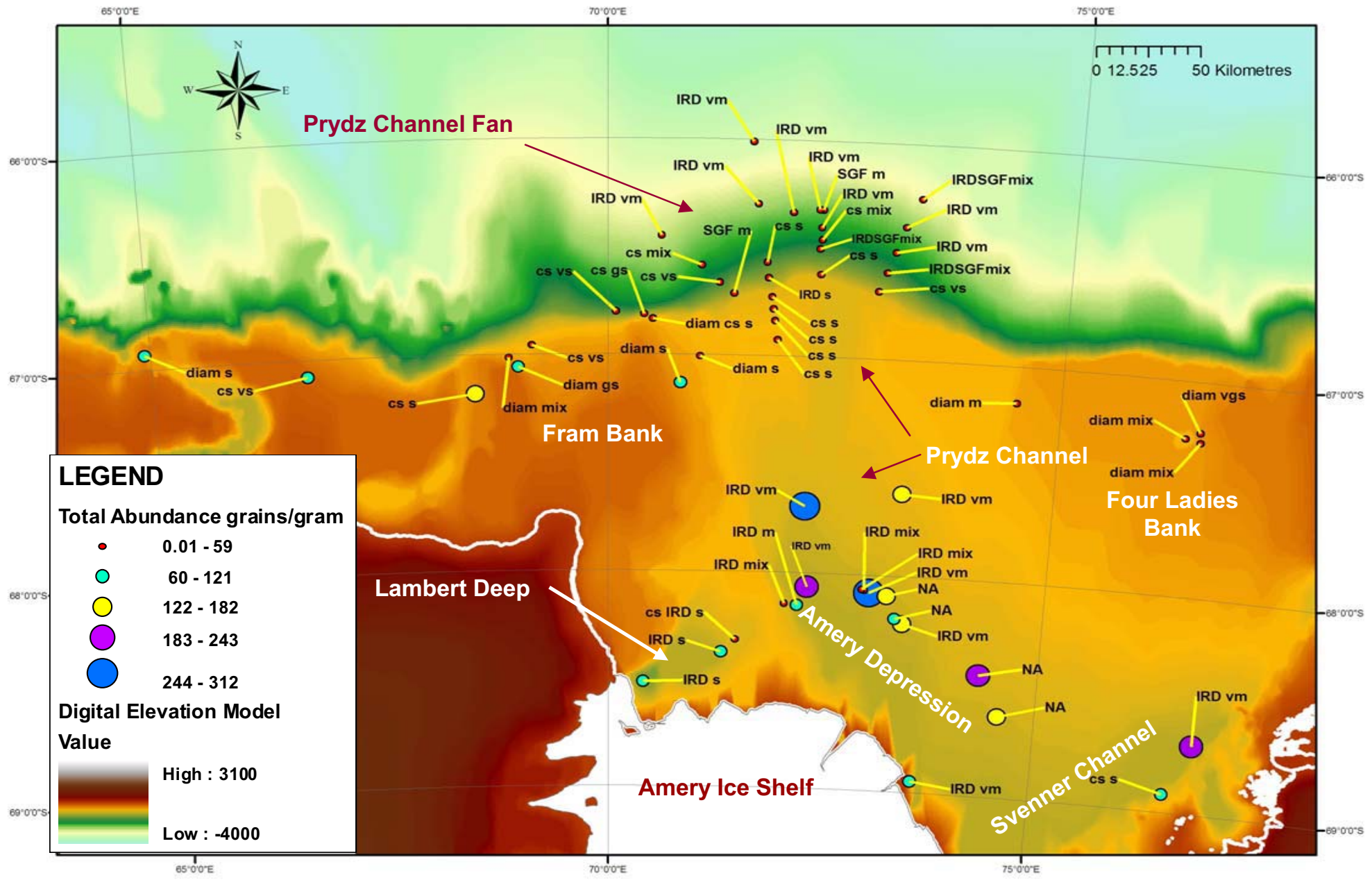

Fig 4.3: Lithology of possible sediment types taken from grain size analysis carried out on each sample. Diamicton (diam), ice rafted debris (IRD), current swept (cs), sediment gravity flow (SGF, gravel and sand (gs), sand (s), very sandy (vs), mud (m), very muddy $(\mathrm{vm})$, an approximately equal amount of coarse gravel and sand, and fine mud $=$ mixture (mix). Also displayed are the grains per gram for total abundance with highest abundance the larger coloured circles as per legend. 


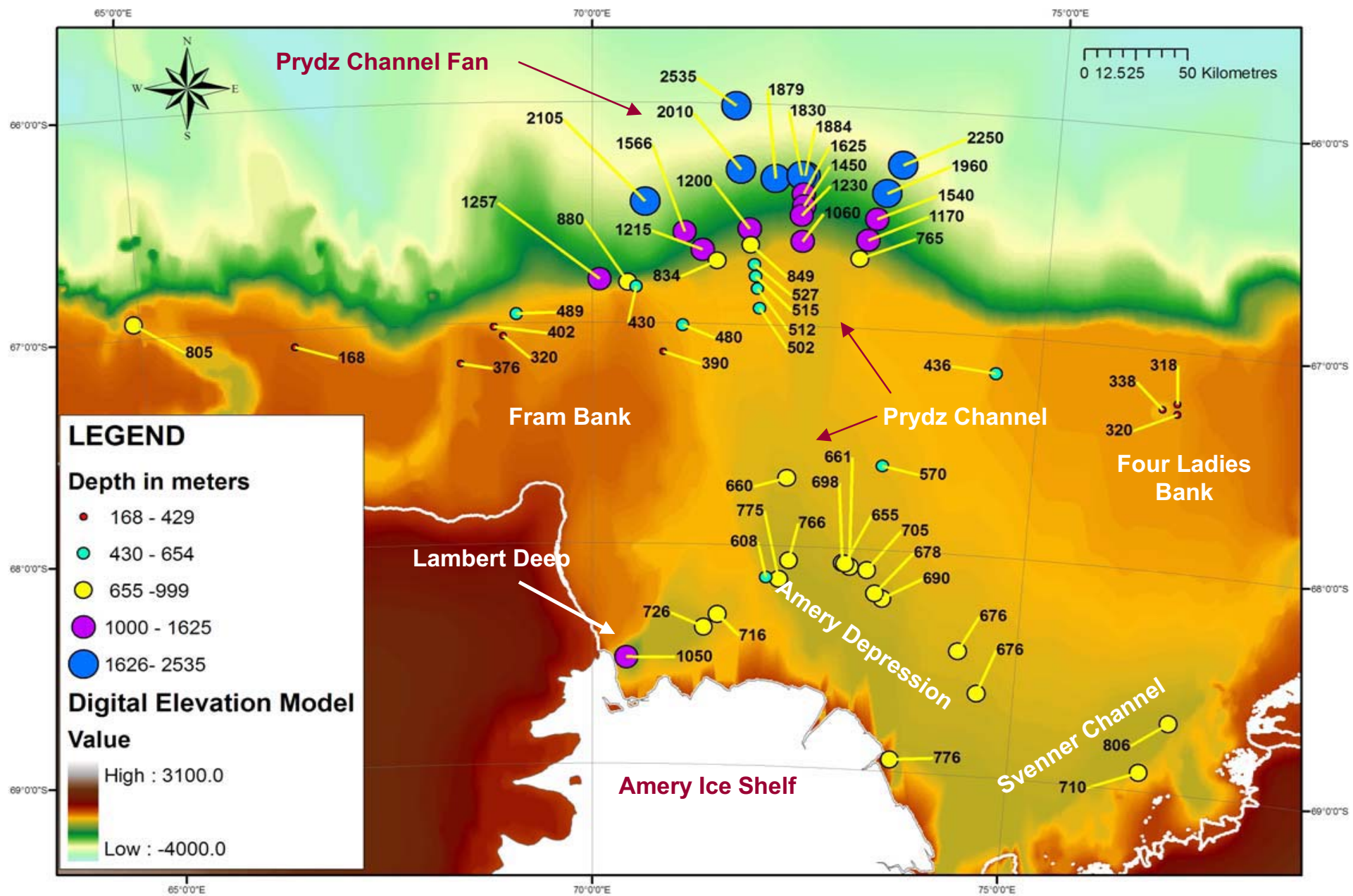

Fig 4.4: Bathymetry depth in meters for each sample shows larger circles with the greater depths. Areas on the continental shelf show that the inner shelf is deeper nearer the Coastal areas of the Lambert Deep and Svenner Channel. The Prydz Channel is deeper in the Mid Shelf area near the Amery Depression but is shallower in the North shelf closer to the Fan. The Four ladies and Fram Banks are shallow in comparison and the Prydz Channel Fan deepens seaward off the continental shelf 


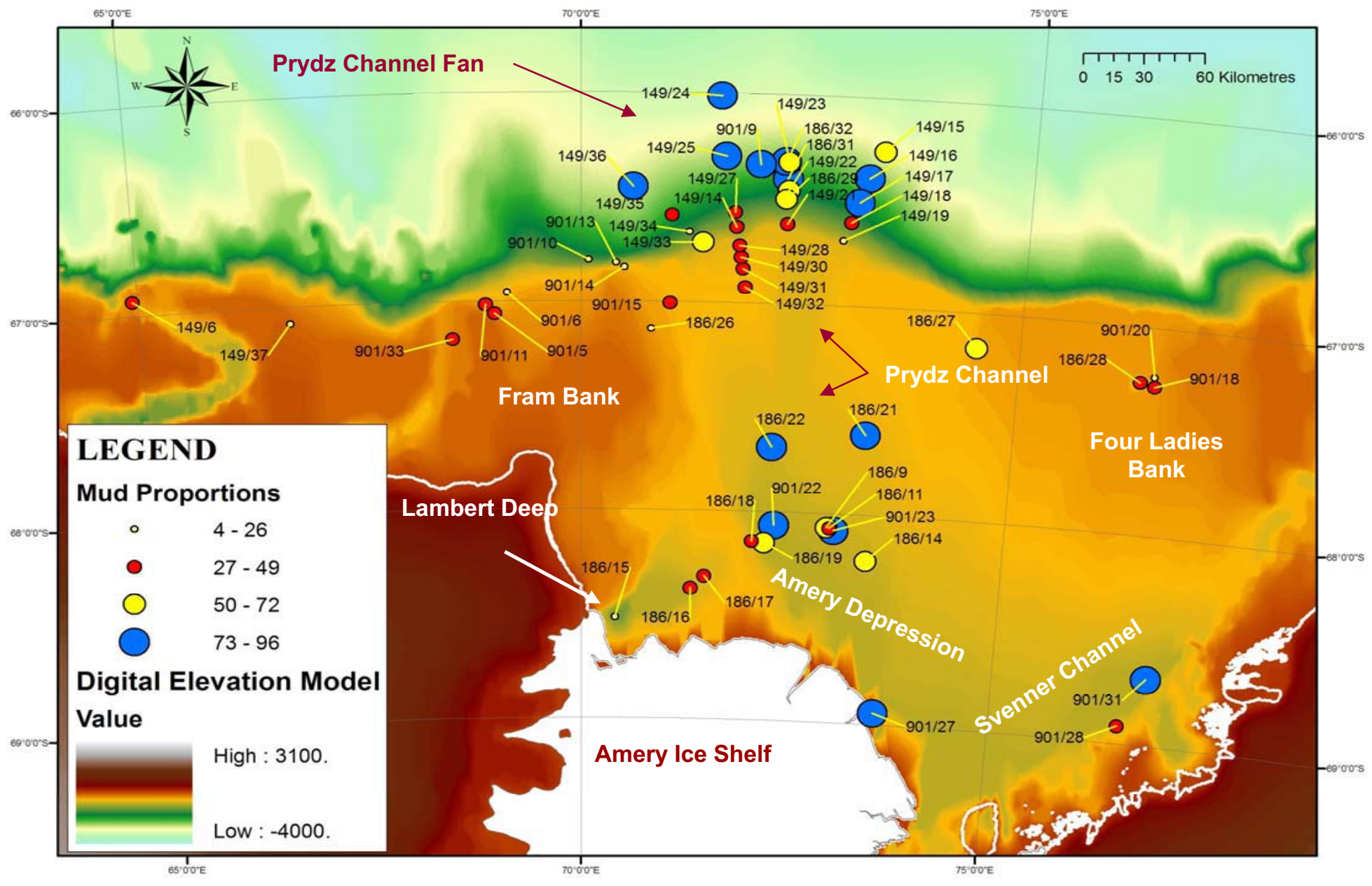

Fig 4.5a: Highest mud proportions shown here as the larger coloured circles (blue) through to smallest mud proportions with smallest circles as per legend. Sample numbers are attached to each circle with a yellow leader. 


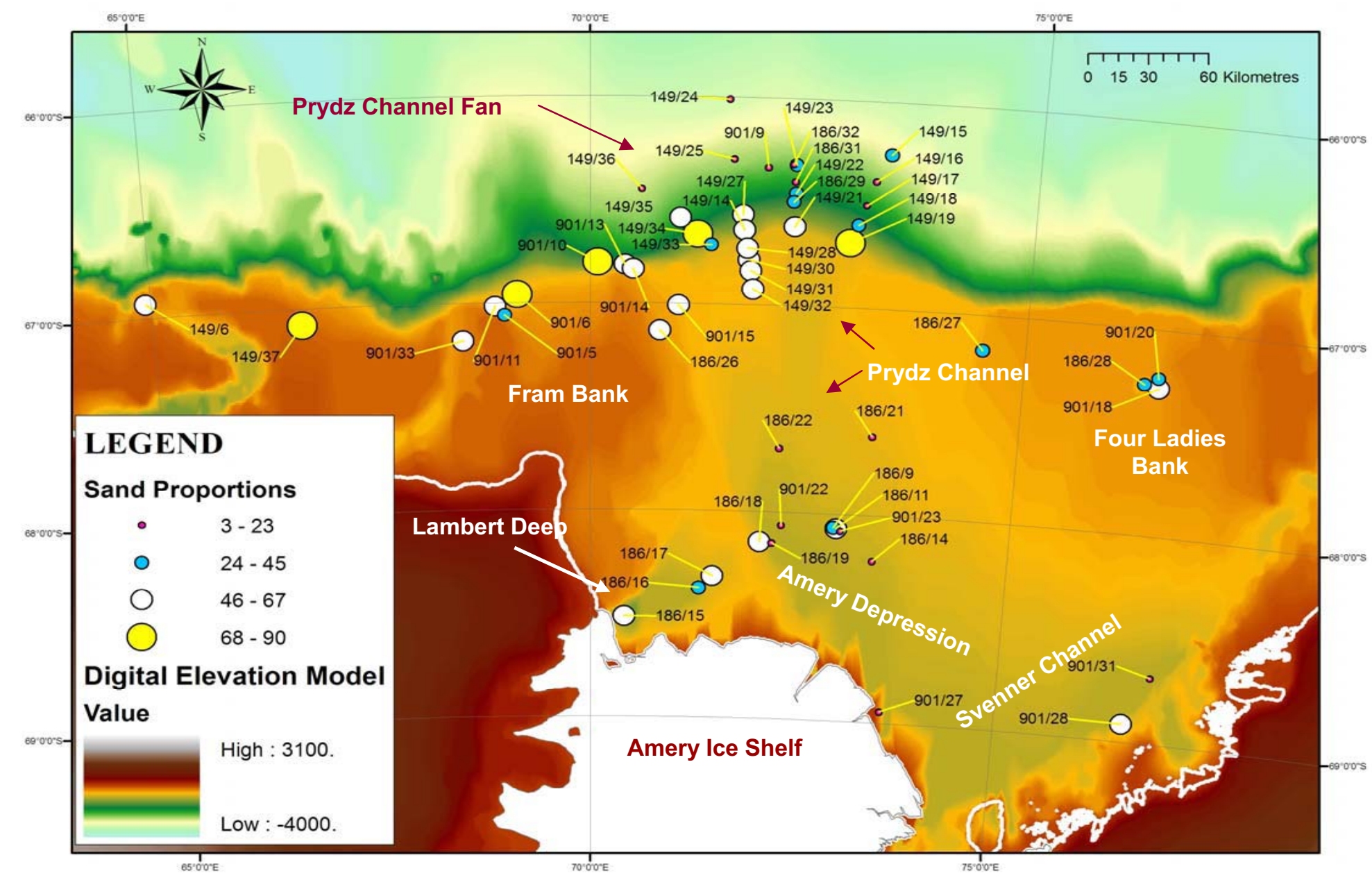

Fig 4.5b: Highest sand proportions shown here as the larger coloured circles (yellow) through to smallest mud proportions with smallest circles as per legend. Sample numbers are attached to each circle with a yellow leader. 


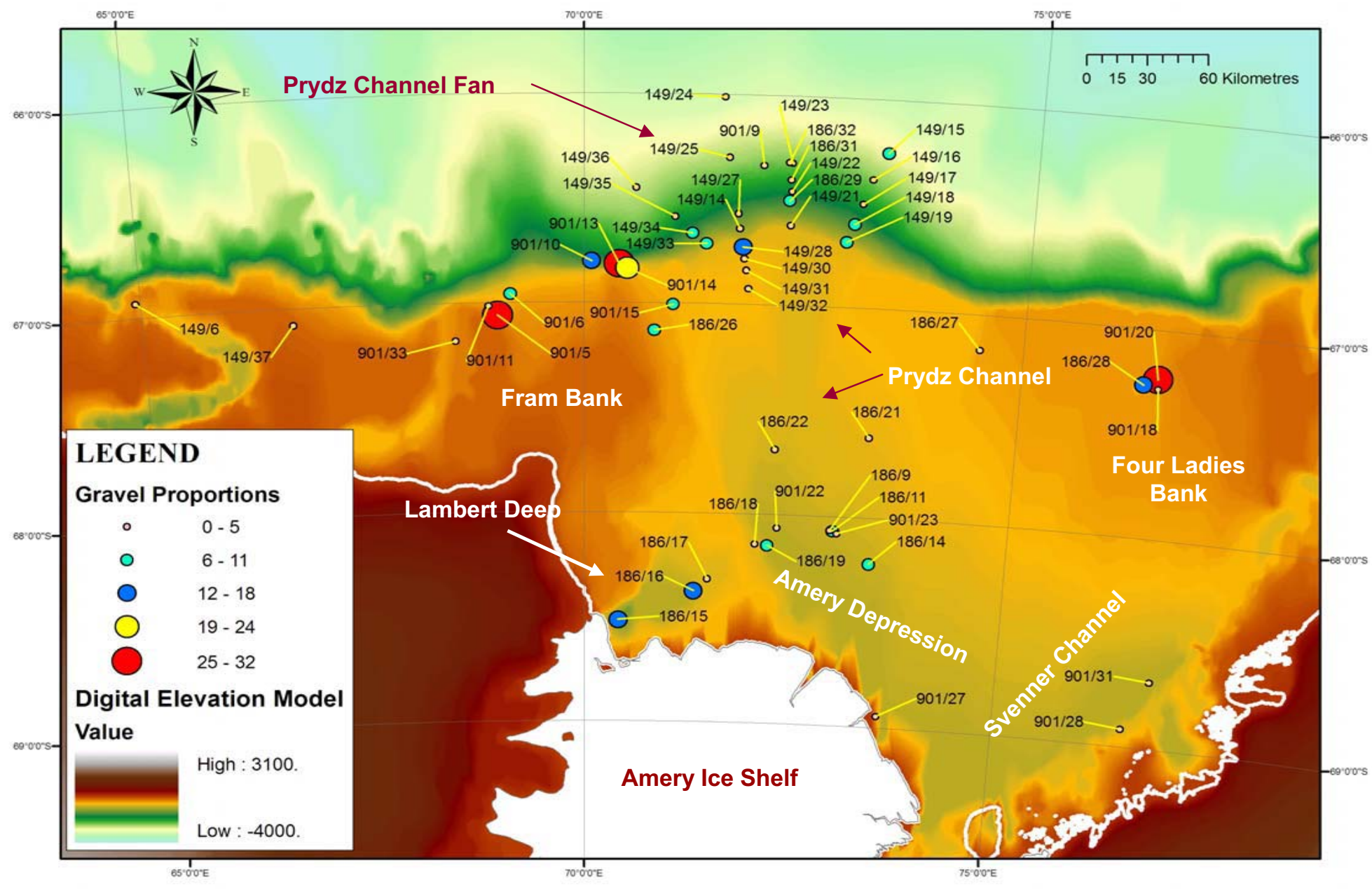

Fig 4.5c: Highest gravel proportions shown here as the larger coloured circles (Red) through to smallest gravel proportions with smallest circles as per legend. Sample numbers are attached to each circle with a yellow leader. 
large proportions of sand $62-72 \%$ (fig $4.5 \mathrm{~b}$ ), consistent with glacial transport and redeposition. Only one sample contains more than 65\% mud (149-33, Appendix B; fig 4.5a).

Further seaward of the shelf edge, at depths of 1,060-1,650 m, sediments are mixed, with gravel proportions $2-12 \%$ up to depths of $1,257 \mathrm{~m}$. High sand proportions (58$82 \%$ ) occurred in some samples (149-21, 149-27, 149-34, 901-10), but six samples (149-18, 186-29, 149-22, 149-17, 149-35, 186-31) contained a higher mud content (50-97\%). Samples from these depths indicate sedimentation in some areas from glacial transport and redeposition but others with sediment largely from suspension.

At greater depths of 1,830-2,535 $\mathrm{m}$ the grain size consisted of very high mud proportions in most samples at $67-95 \%$ mud, with one sample (149-15) at 2,250 m, containing a more even distribution 7\% gravel, $40 \%$ sand and 53\% mud (Appendix B). The high mud content of these surface samples in deep water indicates a lack of current sorting, though the mud itself may well have come from currents winnowing mud from glacially deposited shelf edge sediments. At these depths grounding of the ice shelf could not occur, but gravel might still have been transported as ice rafted debris or sediment gravity flows. O'Brien (1994) suggested that sediment gravity flows were present at various depths, from results obtained from echo sounder records.

\subsection{North Shelf}

\subsubsection{Four Ladies and Fram Banks}

The Four Ladies and Fram Banks (Table 4.1) are the shallowest parts of the embayment. Between 168-805 m on the Fram Bank the sea floor is sandy (54-90\%), and current sorted, apart from 901-5 which is a diamicton (gravel $32 \%$, sand $38 \%$, mud 30\%). The Four Ladies Bank samples between 318-338 $\mathrm{m}$ also show the grain size was mixed and variable for all three samples typical of diamicton (fig 4.2, fig 4.5a, b, c). O'Brien \& Leitchenkov (1997) have described these areas as shallow and disturbed by scouring from iceberg keels and the strong coastal currents. These conditions cause the removal of finer sediments which once disturbed remain in 
suspension and are unable to settle on the Banks, but are carried by currents to settle in quieter waters.

\subsubsection{Northern Prydz Channel}

Surface sediment samples here are between the Four Ladies and Fram banks, but in relatively shallow depths between 390-527 $\mathrm{m}$ (fig 4.4, Table 4.1). Almost all samples are moderately sandy (54-65\%), with a little gravel (1-16\%), and are interpreted as current influenced with some ice-rafting. Only 186-27 has a higher mud proportion of $63 \%$ and no gravel, and plainly results from suspension sedimentation. The area deepens slightly more in the centre due to a fast-flowing ice stream that once eroded the Prydz Channel and transported debris from the Lambert Graben and the inner shelf areas, out to the shelf edge and depositing it on the upper slope of the fan during glacial advance of the Amery Ice Shelf (O'Brien et al. 2004).

\subsection{Mid Shelf}

\subsubsection{Prydz Channel}

In Prydz Channel textures are variable, with all nine samples in deep water (570-775 $\mathrm{m}$, fig 4.4) ranging from somewhat to extremely muddy (41-95\%, fig 4.5a). Four had no gravel, limited sand and more than $88 \%$ mud, and hence were largely from suspension. The other five ranged from 19 to $52 \%$ sand and from 0.4 to $11 \%$ gravel, indicating significant ice rafting, with possibly some patches of basal glacial debris.

\subsubsection{The Amery Depression}

Only one of the five samples from this area could be used for grain size analysis as explained in section 4.1. This sample was 186-14 and at a depth of $690 \mathrm{~m}$ (fig 4.4), its grain size consisted of gravel $9 \%$, sand $19 \%$ and mud $72 \%$. (fig $4.5 \mathrm{a}, \mathrm{b}, \mathrm{c}$ ). The grain size histogram suggests this sample was deposited as ice-rafted debris (high mud content with coarse tail, as in sample 901/27, fig. 4.2). The samples not analysed contained high counts of palynomorphs and may have had a finer grain size, which would be consistent with other samples with high palynomorph counts. Previous work in the Amery Depression (Domack et al. 1991, Pushina et al. 1997) recorded $\sim 1.2 \mathrm{~m}$ of thick diatomaceous ooze in this area, which overlay thin sandy to silty intervals, which in turn overlay dark grey diamicton and sandy pebbly clay. 
O'Brien (1999) suggests that the mid shelf area contains grounding line wedges and moraines probably laid down by the Lambert Glacier. There is speculation that the eastern part was grounded while the western side was still floating (O’Brien \& Leitchenkov, 1997). Several reasons for this could be a difference in mass balance conditions between the eastern and western sides of the ice sheet, or the different response to sea level rise from the east and west sides of the glacier. O'Brien (1994) suggests that the last deglaciation and sea level rise would have floated the western side which is $100 \mathrm{~m}$ deeper than the Four Ladies Banks area on the eastern side. Once floated the western side would have thinned rapidly with the grounding line retreating. The slower retreat on the eastern side left thick glaciomarine muds between the two sides which accounts for the findings in the area from this study.

\subsection{Coastal}

\subsubsection{Lambert and Nanok Deeps}

Three surface samples taken from the Lambert (186-15) and Nanok Deeps (186-16, 186-17), from the western edge of the Amery Ice Shelf at depths between 710-1,050 m., were predominantly sandy (46-62\%) with some gravel (3-17\%) (fig 4.5b, c). These samples are just seaward of the western edge of the Amery Ice Shelf, and likely influenced by westerly currents which probably resulted in the winnowing out the finer sediment and deposition of ice-rafted sediment in these unusually deep shelf basins.

Sample 901-27 has a similar depth $780 \mathrm{~m}$ as the three samples above but has much higher mud content (88\%), and some gravel (2\%). Its position is directly in front but towards the south eastern part of the Amery Ice Shelf which places it in a different environment from the Lambert and Nanok deeps, but similar to the deeper part of the Svenner Channel (fig 4.5a).

\subsubsection{Svenner Channel}

The Svenner Channel area is in the south east of Prydz Bay where two samples were analysed. Sample 901/31 was situated on the Svenner Channel floor and deeper at 
$806 \mathrm{~m}$ with a very muddy content (82\%) (fig 4.5a). Sample 901-28 was shallower at $710 \mathrm{~m}$ (fig 4.4) and predominantly sandy (64\%), and was positioned to the side of the Channel, an area close to a basement outcrop composed of steep sided hills and $\mathrm{U}$ shaped valleys, which O'Brien (1994) suggests may have been formed by the erosion of softer, finer sediments. Neither sample contained gravel, unlike the other coastal samples which all contained proportions of gravel mentioned above (fig $4.5 b)$.

\subsection{Mud distribution and palynomorph abundance}

The mud contour map (fig 4.1a) is a combination of samples from past surveys (Harris et al. 1998) combined with mud proportions from this study and shows the possible mud distribution across the Prydz Bay continental shelf. The samples, represented by different sized coloured circles on the map, are the palynomorph total abundance grains per gram analysis from this study and show that areas with higher proportions of mud generally contain a higher abundance of palynomorphs, with one exception and this is in the Lambert and Nanok deeps. The gravel proportions (fig 4.1b) were analysed from the grain size taken from this study only. Comparison of both data reinforces analysis of grain size shown as proportions of mud and gravel in figures $4.5 \mathrm{a}$ and $\mathrm{c}$.

Figure 4.6a, b, c, and d shows percent mud versus counts for pollen and marine palynomorphs have no relationship, but percent gravel does have a relationship to counts for marine palynomorphs and pollen. A possible interpretation could be that at least in significant part, both pollen and marine palynomorph assemblages are from a glacially derived debris source. 

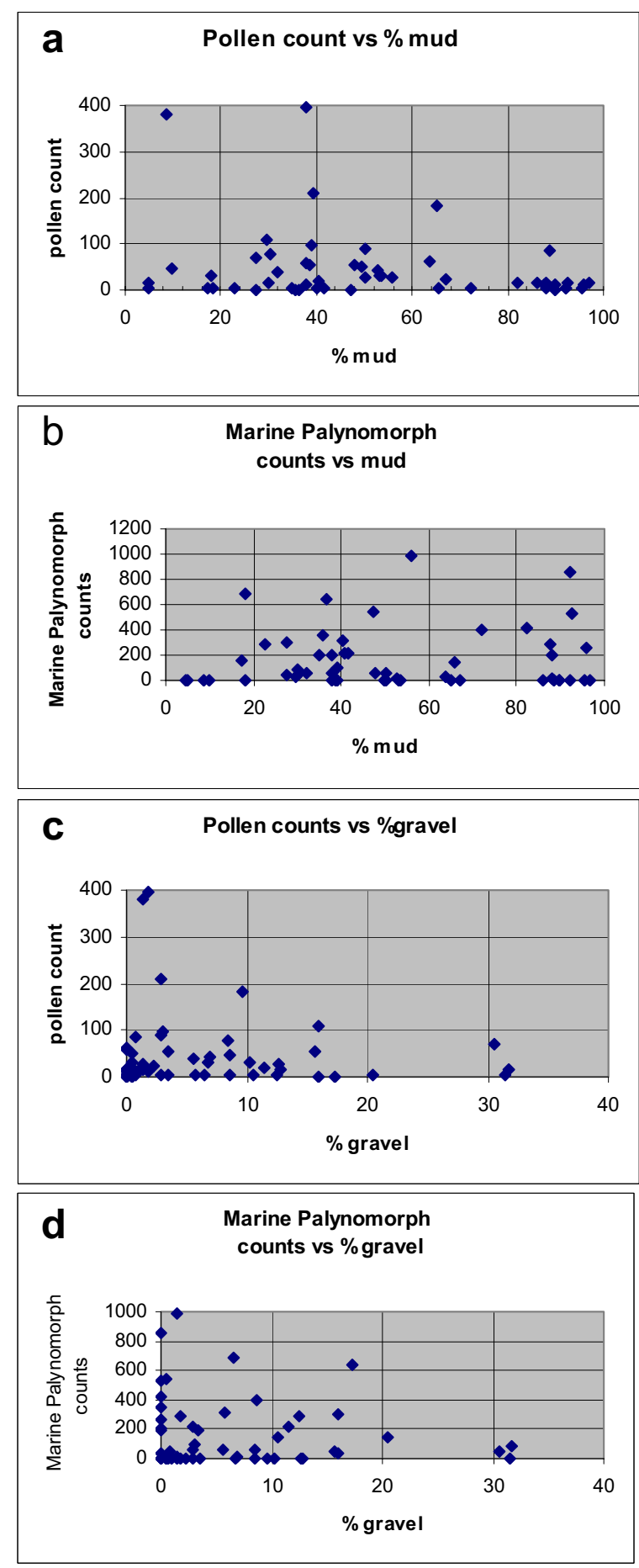

Fig. 4.6: Graphs displaying (a) pollen counts vs \% mud, (b) marine palynomorph counts vs \% mud, (c) pollen counts vs \% gravel and (d) marine palynomorph counts vs \% gravel. Results show no relationship between the \% mud and pollen and marine palynomorph, but a relationship between \% gravel and pollen and marine palynomorphs. 


\section{CHAPTER 5}

\section{DISCUSSION}

\subsection{Introduction}

Most of the samples collected for this project have been affected by modern environmental factors such as current winnowing which removed a lot of the finer material in the shallow areas of the embayment, or iceberg ploughing. Icebergs on the eastern side of the bay are swept along by the coastal currents traveling west and are either carried across the shelf edge or along the coast towards the Amery Ice Shelf (O'Brien, 1994). Areas on the Four Ladies Bank that are compacted till with a smooth sea floor (O'Brien \& Leitchenkov, 1997) are protected because of the shoaling that is created by kick points made by icebergs when they ground into the banks. Many icebergs with keels that are $>300 \mathrm{~m}$ deep kick into and gouge out the shallow banks, and may wallow there disturbing and suspending sediment which may later be reworked back into the sediment. The icebergs may then break up and pass over the area without disturbing sediment protected by shoaling (O’Brien \& Leitchenkov, 1997). Three samples had a high mud content on the Four Ladies Bank (901/18, 186/27, 186/28), which may mean that they remained undisturbed by iceberg ploughing. Reworked pollen distribution in Prydz Bay could be current affected and sea floor samples from the 1911-14 Australasian Antarctic Expedition contained large amounts of recycled pollen on the east coast between $91^{\circ} \mathrm{E}-146^{\circ} \mathrm{E}$ (Truswell, 1982). Some of this pollen if disturbed may remain in suspension long enough to be transported by the coastal currents into the embayment and become entrapped within the Prydz Bay Gyre to eventually settle in the Mid Shelf or Coastal areas.

Figure 3.7 shows water is more saline in the north and north west of Prydz Bay and the gyre may account for the high salinity waters entering the embayment. The inflow from the east by the coastal current is less saline and an area of low salinity can be seen stretching across the Coastal areas of the Svenner Channel and in front of the Amery Ice Shelf. Salinity affect the prasinophycean algae Cymatiosphaera sp. 2 (fig 3.6) which are found in abundance in two samples $(186 / 15,901 / 27)$ from the 
lowest salinity areas in front of the ice shelf. This is consistent with studies in the Arctic where Cymatiosphaera species are found in areas of low salinity and meltwater (Mudie, 1992).

The grain size distribution in Prydz Bay combined with the total abundance for palynomorphs in figure 3.11 shows that the higher abundances were found in higher mud content of sediments within the Mid Shelf and Coastal areas, however, in some samples individual species with high counts were dominant regardless of high mud content e.g. Zooplankton sp. (901/33, 186/16) and Cymatiosphaera sp. 2 (186/15). Figure 4.6 shows that there is a relationship to percent gravel and counts for marine palynomorphs and pollen which may be due in part to sources from glacially derived debris, but there is no relationship for percent mud and counts for marine palynomorphs and pollen. Currents also controlled the distribution of palynomorphs occurring in the North West Fram Bank and in the distribution of most Holocene palynomorphs e.g. Beringiella was more widely distributed on the shelf areas. These factors indicate that processes such as the water currents dominated by the gyre and Coastal Current, combined with the influence of water depth and salinity, the sediment deposition created by glacial erosion in the past and the open marine conditions today, are all influences controlling the distribution of palynomorphs within the embayment.

\subsection{Palynomorph assemblages in Prydz Bay}

Samples from the Prydz Bay Fan and the North Shelf contain mostly reworked palynomorphs (figs $3.9,3.10$ ). The disturbance of the sediments on the Fan by sediment gravity flows and contour currents and on the North Shelf by water currents and iceberg ploughing has brought to the surface the reworked terrestrial and marine palynomorphs contained in these sediments. Figure 3.1 shows Holocene palynomorphs are rare on the Fan due to contour currents and sediment gravity flows disturbing the sediment and winnowing out the finer grain size in shallower depths on the Fan. Holocene palynomorphs cannot settle in this environment. The reworked palynomorphs present within the sediment consist of terrestrial pollen grains and spores which date from the Permian and Jurassic. Reworked dinocysts are poorly preserved and have been dated as Eocene/early Oligocene and are part of 
the Transantarctic Flora. The Miocene marks the beginning of ice sheet advances in Prydz Bay and must be the reason why the reworked dinocysts come from that epoch.

Figure 3.1 shows the Holocene palynomorph assemblage on the Fram Bank contained few reworked palynomorphs. This differs from the Four Ladies Bank and North Prydz Channel. The gyre and Coastal Current as shown in figure 2.1 must be recirculating the Holocene palynomorphs which are found mostly in Mid Shelf and Coastal areas. The high proportions of sand found on the Fram Bank samples combined with the shallow water depths (168-527 m) also indicate currents have winnowed out the fines. For example, $901 / 33$ has a high sand grain size (62\%) and a high Holocene marine palynomorph count $(174 \mathrm{~g} / \mathrm{g})$ with very little reworked palynomorphs $(0.51 \mathrm{~g} / \mathrm{g})$. Such a high Holocene marine palynomorph count in coarse sediments in a shallow area would only occur if carried there recently by the coastal current or the northward flowing arm of the gyre. Other samples on Fram Bank have high counts for foraminiferan test linings (fig 3.4) and to a lesser degree Zooplankton sp. (fig 3.3), Sphaeromorphs (Appendix D) and lower abundances of Beringiella sp. (fig 3.5) and Cymatiosphaera sp. 2 (fig 3.6). 149/6 is the exception and contains high counts of pollen and a few Zooplankton sp. and notably a number of Cymatiosphaera sp. 1. 149/6 is far enough west to be considered almost part of the MacRobertson Shelf and is deeper $(805 \mathrm{~m})$ and out of range of the gyre, and these facts combined give 149/6 a different environment from other samples on the Fram Bank.

Figure 3.1 shows that the North Prydz Channel and the Four Ladies Bank have very low counts of Holocene palynomorphs. Figure 3.9 shows high counts for reworked dinocysts and figure 3.10 shows very high counts for terrestial palynomorphs in the same areas. There may be more reworking occurring in these areas than the Fram Bank, or incoming material from the coastal current may contain more reworked palynomorphs. This suggests little transport of marine palynomorphs in the southward flowing arm of the gyre (fig 2.1). The Four Ladies Bank has higher mud proportions in three samples (fig $4.5 \mathrm{a}$ ) but figure $4.5 \mathrm{c}$ shows one sample $901 / 20$ very high in gravel, whereas the North Prydz Channel shows a higher sand proportion. The grain size in these areas differs from sample to sample and contrasts with the 
palynomorph assemblages present which show a similarity in all of these samples. Overall the North Shelf and Fan areas are still lower in abundance than Mid Shelf and Coastal areas.

Prydz Bay deepens (fig 4.4) from the North shelf to the Mid shelf region, an area where a fast flowing ice stream once carried debris out to the shelf edge which now creates a different environment for cyst settlement. The sediment in the Mid Shelf is deposited at greater water depths (570-775 m) and not disturbed by surface currents or iceberg ploughing, resulting in high mud content (fig 4.5c). The Mid Shelf is where the highest abundances of Holocene marine palynomorphs are located and there is a notable increase in acritarchs and Holocene dinocysts. Pollen counts are high in one or two samples and may have been transported into this area by the coastal currents and the south flowing arm of the gyre. Figure 3.1 shows that all samples from the Mid Shelf have a high total Holocene abundance of marine palynomorphs. Figure 4.1a is the mud contour map and clearly shows this area and parts of the Coastal region have a high mud percent.

The Coastal region is the deepest part of the embayment caused by the expanding Amery ice sheet which eroded sediment and moved it towards the North Shelf. Grain size is variable and mud, sand, or gravel predominates in different samples. Gravel and sand predominate in the Lambert Deep which may be due to disturbance by currents exiting beneath the Amery Ice Shelf. The Prasinophyte Cymatiosphaera sp. 2 (fig 3.6) has a high abundance in the sample closest to the exit area in the Lambert Deep (186/15) along with a reasonable Acritarch count. The Nanok Deep samples $(186 / 17,186 / 18)$ have a high abundance of foram linings, and overall this western part of the Coastal area has very high counts for Zooplankton sp, with low numbers of most other marine palynomorphs. Notably the sample taken on the eastern part of the Amery Ice shelf (901/27) shows a very high count for the Cymatiosphaera sp. 2. In the Svenner Channel area to the east, there are two samples $(901 / 28,901 / 31)$ that vary in their counts according to the type of grainsize and depth within the Channel (fig 4.4; Table 4.1). The deeper sample contains a finer grain size and a higher palynomorph count. There is notably a very small pollen content in all the Coastal samples and overall this geographic area has the second highest palynomorph abundance within Prydz Bay. 


\subsection{Comparison with other modern assemblages}

In the Southern Ocean, Harland et al. (1998) found the number of cysts declined from the Antarctic Polar Front $\left(\sim 50^{\circ} \mathrm{S}\right)$ towards the higher latitudes. This clearly distinguishable distribution pattern is in agreement with the Arctic studies of Mudie (1992) and Rochon et al. (1999). Harland et al. (1998) found that this decreasing diversity with increasing latitude corresponded with an increase in heterotrophic dinocysts and decrease in autotrophic dinocysts. Harland et al. (1998) related the increasing number of heterotrophs as due to upwellings north of the maximum sea ice limit of $\sim 60^{\circ} \mathrm{S}$. In contrast Mudie (1992) relates the A:H ratio to autotrophic dinocysts dominating summer open waters with higher salinity values $(>27 \%)$ and heterotrophic dinocysts increasing with ice thickness and reduced salinity (17-27\%). The A:H ratios of $<0.2$ marked permanent pack ice, tidewater glacier and glaciofluvial environments in the Arctic. This study has recorded more heterotroph than autotroph dinocysts within Prydz Bay.

Other studies in the Southern Ocean by Marret \& de Vernal (1997) showed a reduction in taxa from the Subtropical (20 taxa) to Sub-Antarctic and Antarctic domains (less than 10 taxa, minimum of 3). Esper \& Zonneveld (2002) also found a clearly distinguishable pattern in distribution of dinocysts as the A:H ratio decreased towards the higher latitudes. High rates of heterotrophic dinocysts dominated from south of $45^{\circ}-55^{\circ} \mathrm{S}$ and the endemic Selenopemphix antarctica increased in numbers, dominating the sea ice zone from $60^{\circ} \mathrm{S}$ to coastal areas. This study has recorded Selenopemphix antarctica as the dominant dinocyst in Prydz Bay. All Southern Ocean studies were in agreement with Arctic studies of changes in biota and distribution with increasing latitude.

Mudie (1992) showed that dinocyst assemblages from surface sediments in the Arctic Ocean usually contain at least 32 dinocyst species and 4 acritarch species. In general, Mudie (1992) found a strong correlation between modern palynomorph cyst distribution and surface water masses with species changing between cool temperate, Sub-Arctic and colder Arctic surface water masses. There was a strong correlation to increase in latitude and reduction of A:H dinocyst ratio, and the presence of acritarchs and prasinophytes indicated deposition in stratified glaciofluvial and 
seasonal meltwater environments. In the Barents Sea north of $84^{\circ} \mathrm{N}$, sediments contained fewer dinocysts (63-165 g/g) and sediments from lower salinity surface meltwater areas frequently contained pransinophytes or Sphaeromorph acritarchs and Leiosphaeridia spp.

A further study in the Arctic (Rochon et al.1999) examined the distribution of recent dinoflagellate cysts in surface sediments throughout the North Atlantic Ocean and adjacent seas and found a higher concentration of taxa on continental shelves and slopes where the primary productivity is highest. Dinocyst species diversity was between 2-18 taxa and North Atlantic samples contained 100-1,000 cysts $/ \mathrm{cm}^{2} \mathrm{yr}$ and Artic seas had moderately low cyst concentrations in the order of $0.1-1 \mathrm{cysts} / \mathrm{cm}^{2} \mathrm{yr}$.

Table 5.1 highlights the 7 species that are represented in both the Arctic and Antarctic Holocene surface sediment studies. Arctic and North Atlantic species that are most abundant include Operculodinium centrocarpum, Nematosphaeropsis labyrinthus, Spiniferites frigidus, Multispinula minuta, Brigantedinium spp, Pheopolykrikos hartmanii, Pentapharsodinium dalei, and Impagidinium pallidum (Mudie, 1992; Rochon et al. 1999). Of 53 dinocyst taxa identified from the analysis of studies on surface sediments of the Southern Indian Ocean, 49 are also reported to occur in modern surface sediments in the Northern Hemisphere (Marret \& de Vernal, 1997). Dinocyst assemblages from the Southern Ocean and Antarctica (Table 5.1) are largely dominated by Selenopemphix antarctica, Brigantedinium spp, Impagidinium pallidum, Nematosphaeropsis labyrinthus, Operculodinium centrocarpum, Impagidinium sphaericum, Protoperidinium spp. and Cryodinium meridianum.

This study has found that the low dinocyst numbers and continuous reduction in diversity southward and the decreasing A:H ratio with increasing high latitude, has meant results for numbers of dinocysts in Prydz Bay have been low. This is indicated by the low dinocyst counts (3.85 grains per gram) and dominance of heterotrophic dinocysts recovered in Prydz Bay. Selenopemphix antarctica, Protoperidinium sp. and Cryodinium sp. were the most abundant dinocyst species in Prydz Bay but none of the Holocene dinocysts from Prydz Bay have been recorded 


\begin{tabular}{|c|c|c|}
\hline \multicolumn{3}{|c|}{ Holocene Surface Sediments } \\
\hline $\begin{array}{l}\text { Arctic } \\
\text { Mudie, } 1992 \\
\text { Rochon et al, } 1999\end{array}$ & $\begin{array}{l}\text { Antarctica } \\
\text { Marret \& de Vernal, } 1997 \\
\text { Harland et al, } 1998 \\
\text { Harland \& Pudsey, } 1999 \\
\text { Esper \& Zonneveld, } 2002\end{array}$ & $\begin{array}{l}\text { Antarctica } \\
\text { Prydz Bay } \\
\text { This study }\end{array}$ \\
\hline $\begin{array}{l}\text { Algidasphaeridium } \\
\text { minutum } \\
\text { Brigantedinium spp. } \\
\text { Impagidinium pallidum } \\
\text { Impagidinium sphaericum } \\
\text { Lejeunecysta } \\
\text { Multispinula minuta } \\
\text { Nematosphaeropsis } \\
\text { labyrinthus } \\
\text { Operculodinium } \\
\text { centrocarpum } \\
\text { Pentapharsodinium dalei, } \\
\text { Polykrikos schwartzii } \\
\text { Spiniferites elongates } \\
\text { S.ramosus } \\
\text { S.mirabilis, } \\
\text { S. belerius } \\
\text { Selenopemphix quanta }\end{array}$ & $\begin{array}{l}\text { Algidasphaeridium } \\
\text { minutum } \\
\text { Brigantedinium spp. } \\
\text { Cryodinium meridianum } \\
\text { Dalella chathamense } \\
\text { Impagidinium pallidum } \\
\text { Impagidinium variaseptum } \\
\text { Impagidinium sphaericum } \\
\text { Nematosphaeropsis } \\
\text { labyrinthus } \\
\text { Operculodinium } \\
\text { centrocarpum } \\
\text { Operculodinium } \\
\text { israelianum, } \\
\text { Protoperidinium spp. } \\
\text { Protoceratium reticulatum } \\
\text { Selenopemphix antarctica } \\
\text { Spiniferites elongates }\end{array}$ & $\begin{array}{l}\text { Selenopemphix } \\
\text { antarctica } \\
\text { Protoperidinium spp. } \\
\text { Cryodinium } \mathrm{sp} \text {. } \\
\text { Alisocysta } \mathrm{sp} . \\
\text { Dinocyst sp. } \\
\text { Hystrichosphaerikium } \\
\text { sp. } \\
\text { Impagidinium } \mathrm{sp} . \\
\text { Protoperidinium } \mathrm{sp} .1\end{array}$ \\
\hline $\begin{array}{l}\text { Acritarchs } \\
\text { Hallodinium spp. } \\
\text { Leiosphaeridia sp. } \\
\text { Sigmopollis } \\
\text { Sphaeromorphs } \\
\text { Prasinophytes } \\
\text { Cymatiosphaera } \\
\text { Pterospermella } \text { sp. } \\
\text { Red Algae } \\
\text { Beringiella } \text { sp. } \\
\text { Others } \\
\text { Lingulodinium } \mathrm{sp} \text {. }\end{array}$ & $\begin{array}{l}\text { Pollen grains, spores, } \\
\text { Foraminiferan linings, } \\
\text { Tintinnid cysts and loricae } \\
\text { Acritarchs } \\
\text { Hallodinium spp. } \\
\text { Prasinophytes } \\
\text { Cymatiosphaera } \\
\text { Tasmanites }\end{array}$ & $\begin{array}{l}\text { Pollen grains, spores, } \\
\text { Foraminiferan linings, } \\
\text { Tintinnid cysts, loricae, } \\
\text { Acritarchs } \\
\text { Leiosphaeridia } \text { sp. } \\
\text { Sigmopollis } \\
\text { Sphaeromorphs } \\
\text { Prasinophytes } \\
\text { Cymatiosphaera, } \\
\text { Tasmanites } \\
\text { Pterospermella } \\
\text { Red algae } \\
\text { Beringiella }\end{array}$ \\
\hline
\end{tabular}

Table 5.1: Palynomorphs that were in abundance in surface sediments from Arctic and North Atlantic from studies by Mudie (1992) and Rochon et al. (1999). Antarctic and Southern Ocean palynomorphs from studies by Marret \& de Vernal (1997), Harland et al. (1998), Harland \& Pudsey (1999) and Esper \& Zonneverld (2002). Palynomorphs found in both the Arctic and Antarctic are in blue and palynomorphs found in both the Southern Ocean and Prydz Bay are in Green. 
in Northern Hemisphere studies. Selenopemphix antarctica, together with Cryodinium meridianum, Dalella chathamense and Impagidinium variaseptum (Harland et al. 1998; Harland \& Pudsey, 1999; Esper \& Zonneveld, 2002) appear to be endemic to Antarctica. Table 5.1 highlights 3 of the species that are represented in Prydz Bay and also found in studies carried out in the Southern Ocean. Most marine palynology studies discuss dinocyst concentrations, however this study has results which include counts for other palynomorphs present in equal and sometimes greater numbers than the Holocene dinocysts. They are the acritarchs, prasinophytes, red algae, tintinnids and foraminifera linings recorded either in the Southern Ocean studies or in the Arctic studies (Table 5.1) and the Zooplankton sp. recorded in very high numbers in this study but not been recorded elsewhere.

\subsection{Ancient and modern assemblages}

The number of living dinoflagellates today is approximately 1,772 marine and 230 freshwater species, many of which are yet to be adequately described. The number of dinoflagellates that produce preservable resting cysts may only be about $10 \%$ of this total (Dale, 1996, Head, 1996). In Antarctica, extant dinoflagellates have been reported in greater numbers than fossil dinocysts. Out of nearly 80 motile species of Holocene dinoflagellates discovered in the Antarctic only five were known to produce cysts (Wrenn et al. 1998). A comparison of the fossil record for Antarctic dinocyst diversity with the record for world wide fossil dinocyst diversity is shown in figure 5.1 from Wrenn et al. (1998). This shows that the limited number of drill holes and the few productive outcrops of marine sediments that do exist, have compared well with the distribution curves for world wide fossil dinocyst diversity, although their abundance is lower (Wrenn et al. 1998).

Most reworked palynomorphs in this project have also been identified from previous work carried out on the palynology of Seymour Island, Antarctica (Wrenn \& Hart, 1988), Deep Sea Drilling Project (DSDP) drill hole (Kemp, 1975), MSSTS-1 drill hole McMurdo Sound (Truswell, 1986) the CIROS-1 Drillhole (Wilson, 1989; Hannah, 1997) and McMurdo Sound Erratics, (Levy \& Harwood, 2000b). Our understanding of Oligocene-Miocene marine palynology of high latitude sites, increased significantly through the Cape Roberts Project (Hannah et al. 1998, Wrenn 


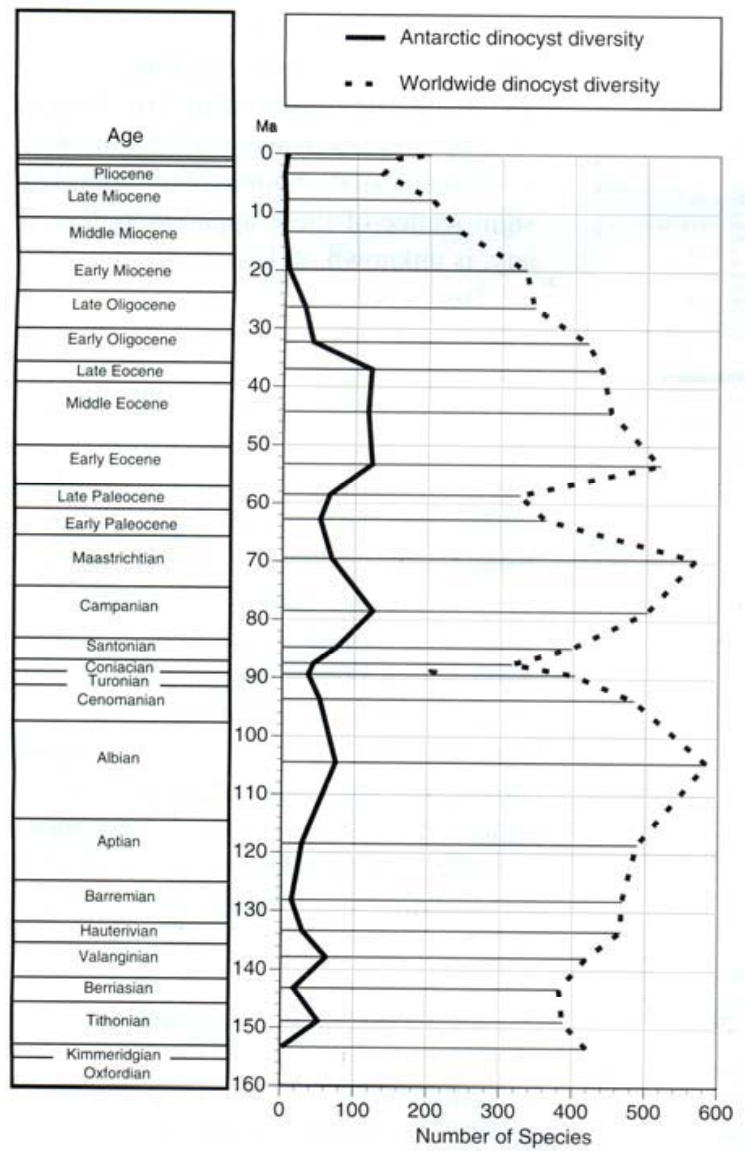

Fig. 5.1: Dinocyst curve in the Antarctic fossil record (solid black line) compared to that of the world-wide dinocyst record. The Antarctic pilot is based on a PALYNODATA search that retrieved data from 91 Antarctic dinocyst papers in its database. The worldwide dinocysts curve is adapted from MacRae et al.1996 (J.H. Wrenn et al. 1998) 
et al. 1998, Hannah et al. 2000, Hannah et al. 2001a) and Ocean Drilling Project sites in Prydz Bay (Hannah, 2005, McPhail \& Truswell, 2004a, b).

The Transantarctic Flora were first recovered from the McMurdo Erratics by Cranwell et al. (1960). The Erratics are fossiliferous and found in coastal moraines around McMurdo Sound, East Antarctica. They provide a record of both ice-free coastal and glacial-marine depositional environments (Levy \& Harwood, 2000). Wrenn \& Hart (1988) further documented the flora from Seymour Island near the Antarctic Peninsular, and since then the flora have been found in situ and dated as mid Eocene to early Oligocene, or as reworked dinocysts in most other projects within the Antarctic. Other palynomorphs that were present in the ancient assemblages in previous work mentioned above and are also present in the surface sediments from this project are acritarchs (Leiosphaeridia spp, Sigmopollis,) and prasinophytes (Cymatiosphaera spp, Pterospermella, Tasmanites).

\subsubsection{Prydz Bay Ocean Drilling Program}

The Ocean Drilling Program (ODP) Leg 119 sites 739 to 743 along with Leg 188 sites 1165, 1166 and 1167 (fig 5.2) were drilled in Prydz Bay with the purpose of investigating glacial/preglacial conditions during the Miocene. ODP site 1165 sampled the Wild Drift on the continental rise; site 1166 was drilled on the eastern part of the continental shelf; site 1167 was drilled on the Prydz Channel Fan.

Hannah (2005) extensively studied ODP site 1165 on the Wild Drift and found both in situ and reworked palynomorphs recognized as a Miocene record of glacial advance and retreat. As the ice sheet expanded a long colder period occurred and high numbers of reworked palynomorphs were evident. Full retreat of the ice shelf reduced the numbers of reworked palynomorphs but brought a generally large increase in numbers of Leiospheres and during warmer periods an increase in other flora was evident (Hannah, 2005). Reworked palynomorphs consisted of terrestrial spores and pollen from the Devonian to Early Eocene, and Transantarctic flora which were reworked into Miocene sediments. In situ palynomorphs consisted of acritarchs, prasinophyte algae and in situ dinocysts that were dominated by 


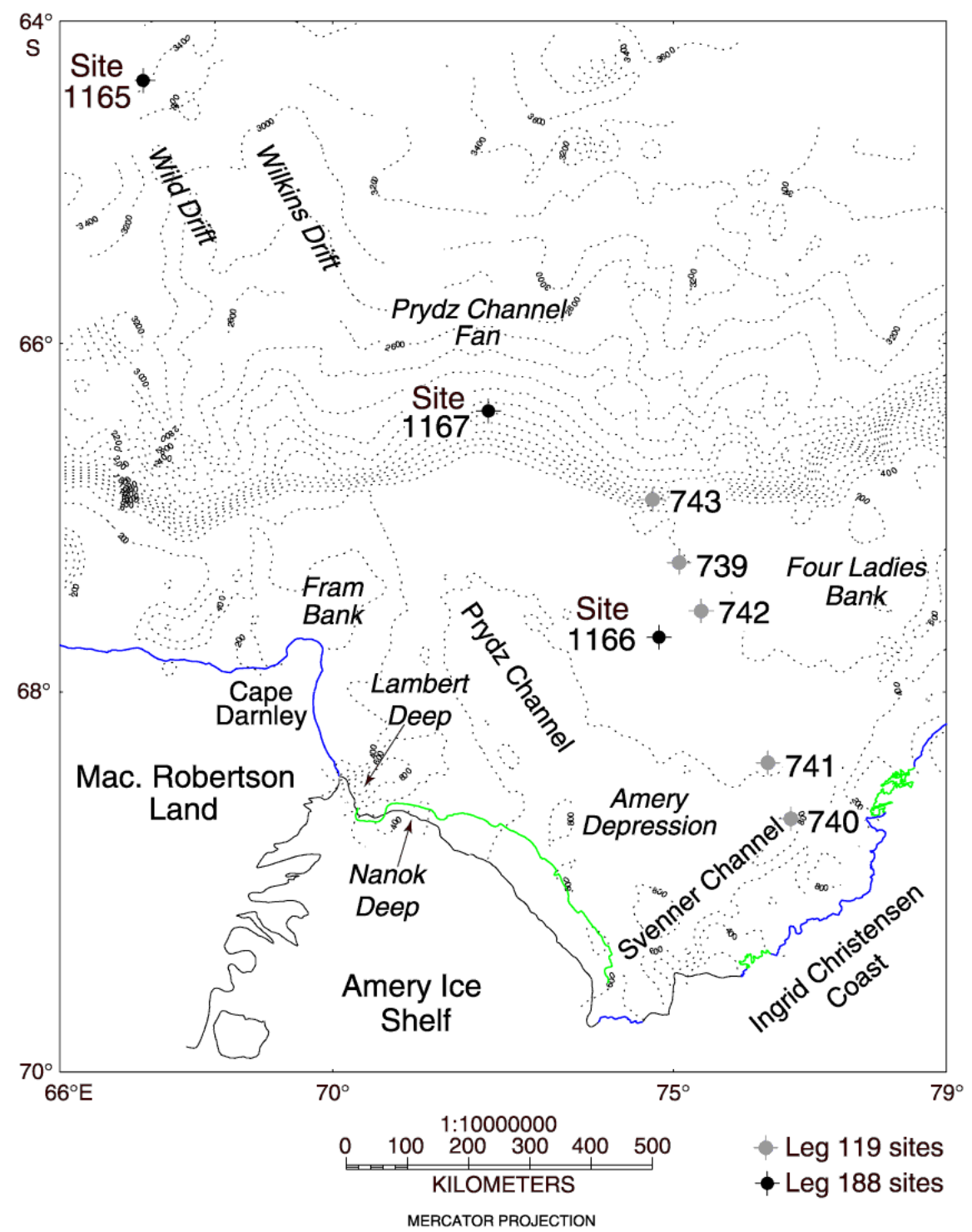

Fig. 5.2: Previous work has been completed by ODP leg 119 where drilling on the shelf (site 166), fan (site 1167) and rise (site 1165) were completed. ODP leg 188 sites were drilled on the continental shelf from site 739 to 743 (O’Brien et al 2001). 
Lejeunecysta. The acritarch Leiosphaeridia was the dominant palynomorph in most samples from the base of the drill hole up to depths of $325 \mathrm{~m}$ below sea floor.

The palynology of ODP sites 1165 and 1167 was initially investigated by MacPhail and Truswell (2004a). Site 1165 contained Neogene dinocysts taxa including Batiacasphaera sp. and also included the Prasinophyte Cymatiosphaera as well as fossil pollen and spores. Site 1167 contained recycled plant microfossils that are Permian and early Jurassic to late Eocene and Oligocene. Neither site contained dinocysts from the Transantarctic Flora. McPhail and Truswell (2004b) studied site 1166 more extensively to recover late Cretaceous and Eocene pollen and spores and in situ dinocysts from the Transantarctic Flora.

A further study by Truswell et al. (1999) reported pollen grains and spores from Mesozoic in the Nielsen basin on the MacRobertson shelf (west of Prydz Bay) and dinocysts have been identified further west on the MacRobertson Shelf which are also present in Prydz Bay surface sediments as Reworked dinocysts from the Trans Antarctic Flora.

There is a higher diversity within the embayment today and a significantly lower level of reworked material than in ancient assemblages recorded throughout Antarctica which reflects warmer conditions today compared to the Ice Shelf advance and retreats of the past. This study contains elements from previous work on the ODP drill holes for Transantarctic Flora, pollen and spores, acritarchs (Leiosphaeridia spp, Sigmopollis) and Prasinophytes (Cymatiosphaera spp, Pterospermella spp). Table 5.2 shows a comparison of ODP drill holes in Prydz Bay and this study. Notably the red algae Beringiella sp. and Tasmanites spp. have not been recorded in the ODP sites and Holocene dinocysts in this study also differ from ODP in situ dinocysts. Other differences are the very low counts found in this study for Leiosphaeridia spp. in reworked or Holocene sediments compared to the high counts from Hannah (2005) that occurred in ODP 1165 during ice shelf retreats in the past. Wild Drift site 1165 is situated on the continental rise to the north west of Prydz Bay, which may mean the lack of similarity of species between Wild Drift and the Prydz Bay embayment may reflect the different environments. It could also reflect a different climate today which has not produced Leiosphaeridia spp. in 


\begin{tabular}{|c|c|c|}
\hline \multicolumn{3}{|c|}{ This Study vs Ancient Assemblages } \\
\hline $\begin{array}{c}\text { This study } \\
\text { Reworked Dinocysts }\end{array}$ & $\begin{array}{c}\text { Hannah, (2005) } \\
\text { Reworked Dinocysts }\end{array}$ & $\begin{array}{c}\text { McPhail \& Truswell } \\
\text { (2004a,b) Transantarctic } \\
\text { Flora Dinocysts }\end{array}$ \\
\hline $\begin{array}{l}\text { Alterbidinium asymmetrica } \\
\text { Deflandrea spp. } \\
\text { Enneadocysta partridge, } \\
\text { Spinidinium sp. } \\
\text { Spinidinium macmurdoense } \\
\text { Turbiosphaera filosa } \\
\text { Vozzhennikovia } \text { spp. }\end{array}$ & $\begin{array}{l}\text { Alisocysta } \mathrm{sp.} \\
\text { Alterbidinium } \\
\text { asymmetricum } \\
\text { Arachnodinium antarcticum } \\
\text { Deflandrea antarctica } \\
\text { Enneadocysta partridgei } \\
\text { Vozzhennikovia aperture }\end{array}$ & $\begin{array}{l}\text { Deflandrea sp. cf. } \\
\text { Deflandrea antarctica } \\
\text { Enneadocysta partridgei } \\
\text { Spinidinium sp. } \\
\text { Spinidinium macmurdoense } \\
\text { Turbiosphaera sp. cf. } \\
\text { Turbiosphaera filosa } \\
\text { Vozzhennikovia aperture }\end{array}$ \\
\hline Other Palynomorphs & Other Palynomorphs & Other Palynomorphs \\
\hline $\begin{array}{l}\text { Pollen grains, spores, } \\
\text { Foraminiferan linings, } \\
\text { Tintinnid cysts, loricae, } \\
\text { Acritarchs } \\
\text { Leiosphaeridia } \text { sp. } \\
\text { Sigmopollis } \\
\text { Sphaeromorphs } \\
\text { Prasinophytes } \\
\text { Cymatiosphaera } \mathrm{spp} . \\
\text { Tasmanites sp. } \\
\text { Pterospermella } \mathrm{spp} . \\
\text { Red Algae } \\
\text { Beringiella } \text { sp. }\end{array}$ & $\begin{array}{l}\text { Pollen grains, spores } \\
\text { Acritarchs } \\
\text { Leiosphaeridia } \text { spp. } \\
\text { Micrhyistridium spp. } \\
\text { Sigmopollis } \\
\text { Prasinophytes } \\
\text { Cymatiosphaera } \text { sp. } 1 \\
\text { Cymatiosphaera } \text { spp. } \\
\text { Pterospermella } \text { spp. }\end{array}$ & $\begin{array}{l}\text { Pollen grains, spores, } \\
\text { Foraminiferan linings, } \\
\text { Prasinophytes } \\
\text { Pterosperma } \text { spp. } \\
\text { Cymatiosphaera invaginata }\end{array}$ \\
\hline
\end{tabular}

Table 5.2: Transantarctic Flora recovered from this project in comparison with Hannah (2005) and McPhail and Truswell (2004a, b). Other palynomorphs shown are pollen grains, spores, acritarchs, and prasinophytes which are also compared. 
numbers but has produced a variety of palynomorphs that were not present in the ancient records. This study records terrestrial palynomorphs from the Permian to the Eocene in contrast to Hannah (2005) who recorded terrestrial palynomorphs from the Devonian to Early Eocene.

\subsubsection{Reworked surficial sediments in the Ross Sea}

Truswell and Drewrey (1984) noted that reworked palynomorphs were evident in surficial sediments in the Ross Sea. The highest densities were immediately north of the Ross Ice Shelf and were dominated by Late Cretaceous to Eocene microfossils. In contrast, this study of Prydz Bay has found that the area immediately north of the Amery Ice Shelf is dominated by modern marine palynomorphs and the highest densities for Prydz Bay reworked palynomorphs were on the North Shelf and Prydz Channel Fan. Also noted by Truswell and Drewrey (1984) were rare Paleozoic spores and Eocene dinoflagellates some of which are also present in Prydz Bay surface sediments namely: Alterbidinium asymmetrica, Deflandrea spp. Turbiosphaera filosa, Vozzhennikovia spp. that are all part of the Transantarctic Flora.

The Ross Sea Ice drainage basin only reflects the Amery Ice Shelf drainage basin in that it has been responsible for the transport of palynomorphs from an expanded ice shelf or from discharge from ice streams. Marine bottom currents do not seem to have significantly affected distribution of the recycled microfossils in the Ross Sea sediments in areas where transport of sediment occurs from a floating ice shelf or discharge from ice streams. Deposition below the ice mass of near grounded or grounded ice leaves only a very short water column with little opportunity to be affected by current transport (Truswell \& Drewrey, 1984). In contrast the Prydz Bay Gyre and the Coastal Current from the east combined with iceberg grounding in the shallower areas of the bay have influenced what is found in the sediments there today. 


\section{CHAPTER 6}

\section{CONCLUSIONS}

This study has demonstrated that:

1. Prydz Bay surface sediment samples contain Holocene palynomorphs, reworked Eocene dinocysts and reworked Permian to Eocene terrestrial palynomorph assemblages. Past glacial processes have created four differing environments (Prydz Channel Fan, North Shelf, Mid Shelf and Coastal areas) in the embayment which is reflected in the palynomorph distribution. In addition, conditions for cyst settlement today are partly controlled by a clockwise rotating gyre which enters the embayment from the north. The southward flowing arm of the gyre combines with the westward flowing coastal current and circulates beneath the Amery Ice Shelf before exiting on the western side and joins the outgoing arm of the gyre north or follows the coastal current west. Processes such as the water currents dominated by the gyre and coastal current, combined with the influence of water depth and salinity, the sediment deposition created by glacial erosion in the past and the open marine conditions today, are all influences controlling the distribution of palynomorphs within the embayment.

2. Most Holocene palynomorphs were contained in the Mid Shelf and Coastal areas with very few located on the North Shelf and very sparse counts on the Prydz Channel Fan. The highest counts were obtained for Zooplankton sp. and foraminifera linings. In situ dinocysts were dominated by the heterotroph form Selenopemphix antarctica, with other palynomorphs identified including acritarchs, prasinophytes and a red algae Beringiella sp. The percentage of gravel to marine palynomorph and pollen counts show a relationship which may reflect a similar source from glacially derived debris but the percentage of mud to marine palynomorph and pollen counts has no relationship.

3. During the early Oligocene, glacial erosion moved terrestrial sediments from the Lambert Graben, deepened the embayment from the Coastal and Mid 
Shelf areas and redeposited and mixed them with marine sediments.

Repeated ice shelf advances towards the shelf edge reworked the sediments into the North Shelf and Fan where elements of the Transantarctic Flora and reworked terrestrial palynomorphs are recorded in low numbers today.

4. In comparison with modern assemblages none of the Holocene dinocysts from Prydz Bay have been recorded in Northern Hemisphere studies. In contrast, all of the Prydz Bay acritarchs, prasinophytes, red algae, pollen grain and spores, foraminiferan linings and tintinnids have been recorded either in the Southern Ocean studies or in the Arctic studies as shown in Table 1.5. In the Arctic, sediments from lower salinity and glacial meltwaters frequently contained pransinophytes or Sphaeromorph and Leiosphaeridia acritarchs.

5. Autotroph:heterotroph ratios decrease with increasing latitude. In the Northern Atlantic high abundances of 100 to $1,000 \mathrm{cysts} / \mathrm{cm}^{2}$ yr were recorded, however in the Arctic north of $84^{\circ} \mathrm{N}$ sediments contained fewer dinocysts (63-165 g/g). In the Sub-Antarctic and Polar Front Zones a high of 2,000 grains per gram noticeably fell to $<250$ grains per gram at $60^{\circ} \mathrm{S}$ and from $60^{\circ} \mathrm{S}$ to higher latitudes the cysts per gram of sediment declined to $<23$ grains per gram and diversity was lower (maximum of six species). In Prydz Bay the Holocene dinocyst count is 3.85 grains per gram with eight species recovered, but two are considered oceanic and carried into the embayment via the Prydz Bay gyre.

6. Most reworked palynomorphs in this project have also been identified from previous work carried out in Prydz Bay ODP drill holes and the McMurdo Sound, Ross Sea area which includes projects such as CIROS-1 and the Cape Roberts Project. They contain elements of the Transantarctic Flora, pollen and spores, acritarchs (Leiosphaeridia spp. Sigmopollis sp.), and prasinophytes (Cymatiosphaera spp. Pterospermella spp. Tasmanites spp.). 


\section{Bibliography}

Allison, I. 1979: The Mass Budget of the Lambert Glacier Drainage Basin, Antarctica. Journal of Glaciology 22 : 223-235.

Allison, I. 2003: The AMISOR project: ice shelf dynamics and ice-ocean interaction of the Amery Ice Shelf. FRISP Report 14 1-9.

Anderson, J.B. 1999: Antarcticas's Glacial History. Antarctic Marine Geology. New York Cambridge University Press. 207-240

Armand L.K.; Leventer, A. 2003: Palaeo Sea Ice Distribution - Reconstruction and Palaeoclimatic Significance. In (eds Thomas, D.N.; Dieckmann, G.S.) Sea Ice: An Introduction to its Physics, Chemistry, Biology and Geology. Blackwell, UK. 333-372

Arrigo, K.R. 2003: Primary Production in Sea Ice. In (eds Thomas, D.N.; Dieckmann, G.S.) Sea Ice: An Introduction to its Physics, Chemistry, Biology and Geology. Blackwell, UK. 333-372

Arrigo, K.R.; Thomas, D.N. 2004: Large scale importance of sea ice biology in the Southern Ocean. Antarctic Science 16 (4) : 471-486

Askin R.A.; Raine, J.I. 2000 : Oligocene and Early Miocene Terrestrial Palynology of the Cape Roberts Drillhole CRP-2/2A, Victoria Land Basin, Antarctica. Terra Antartica 7 (4) : 493-501.

Barrett, P.J.; Anderson, J. 2000: Grain Size Analysis of Samples from CRP-2/2A, Victoria Land Basin, Antarctica. Terra Antartica 7 (3) : 373-378.

Batten D.J. 1996: Palynofacies. In (eds, Jansonius, J; McGregor, D.C) Palynology: principles and applications; American Association of Stratigraphic Palynologists Foundation, Vol. 3. 1011-1064

Boggs, S. 1995: Principles of Sedimentology and Stratigraphy. Second ed.

Brasier, M.D. 1980 : Microfossils. George Allen \& Unwin, London

Church, J.; Bindoff, N.; Hunter, J.; Rosenberg, M. 2002 : Why are we so interested in the Amery Ice Shelf? Australian Antarctic Magazine. 3 : 27-28.

Comiso, J.C. 2003: Large-scale Characteristics and Variability of the Global Sea Ice Cover. In (eds Thomas, D.N.; Dieckmann, G.S.) Sea Ice: An Introduction to its Physics, Chemistry, Biology and Geology. Blackwell, UK. $333-372$ 
Cooper, A.K; Barrett, P.J.; Hinz, K.; Traube, V.; Leitchenkov, G.; Stagg, H.M.J.

1991 : Cenozoic prograding sequences of the Antarctic continental margin: a record of glacio-eustatic and tectonic events. Marine Geology 102 : 175-213.

Cooper, A.K.; O’Brien P. E. 2004 : Leg 188 Synthesis: Transitions in the Glacial History of the Prydz Bay Region, East Antarctica, from ODP Drilling. In Proceedings of the Ocean Drilling Program, Scientific Results. (Eds:

Cooper, A.K.; O’Brien, P.E.;Richter, C.) Volume 188

Cooper, A.; Stagg, H.; Geist, E. 1991: Seismic Stratigraphy and Structure of Prydz Bay, Antarctica: Implications from Leg 119 Drilling. In Barron, J.;Larsen, B. et al Proc. ODP, Sci. Results, 119: College Station, TX (Ocean Drilling Programme) 5-25

Cranwell, L.M.; Harrington, H.J.; Speden, I.G. 1960 : Lower Tertiary microfossils from McMurdo Sound, Antarctica. Nature Vol 184(4701) : 1782-1785

Dale, B. : 1996 Dinoflagellate Cyst Ecology: Modeling and Geological Applications. In (eds Jansonius, J.; McGregor, D.C.) Palynology: principles and applications; American Association of Stratigraphic Palynologists Foundation, Vol. 3 1249-1275

Davey, F.J. 1985 : The Antarctic Margin and its possible Hydrocarbon potential. Tectonophysics $114: 443-470$

Dieckmann, G.S.; Hellmer, H.H. 2003: The Importance of Sea Ice: An Overview In (eds Thomas, D.N.; Dieckmann, G.S.) Sea Ice: An Introduction to its Physics, Chemistry, Biology and Geology. Blackwell, UK. 333-372

Devillers, R.; de Vernal, A. 2000 : Distribution of dinoflagellate cysts in surface sediments of the northern North Atlantic in relation to nutrient content and productivity in surface waters. Marine Geology 166 : 103-124

Domack, E.W.; Jull, A.J.T.; Donahue, D.J. 1991 : Holocene Chronology for the Unconsolidated Sediments at Hole 740A: Prydz Bay, East Antarctica. In Barron, J.;Larsen, B. et al Proc. ODP, Sci. Results, 119: College Station, TX (Ocean Drilling Programme) 747-750.

Dunbar, R.B. and Leventer, A.R. 1989. Biogenic sedimentation in McMurdo Sound, Antarctica. Marine Geology 85, 155-179.

Eicken, H. 2003: From the Microscopic, to the Macroscopic, to the Regional Scale: Growth, Microstructure and Properties of Sea Ice. In (eds Thomas, D.N.; 
Dieckmann, G.S.) Sea Ice: An Introduction to its Physics, Chemistry, Biology and Geology. Blackwell, UK. 333-372

Esper, O.; Zonneveld, K.A.F. 2002. Distribution of organic-walled dinoflagellate cysts in surface sediments of the Southern Ocean (eastern Atlantic sector) between the Subtropical Front and the Weddell Gyre. Marine Micropaleontology. $46: 177-208$

Fensome, R.A.; Riding, J.B.; Taylor, F.J.R. 1996 : Dinoflagellates. In (eds, Jansonius, J; McGregor, D.C) Palynology: principles and applications; American Association of Stratigraphic Palynologists Foundation, Vol. 1. 107-169

Franklin, D. 1991: The Marine environment of Prydz Bay, Antarctica: Microbiota and Facies Distribution. Honours Thesis submitted. The Department of Geology. The Australian National University, Canberra, Australia

Franklin, D.C.; Marchant, H.J. 1995 : Parmales in sediments of Prydz Bay, East Antarctica: a new biofacies and paleoenvironmental indicator of cold water deposition? Micropaleontology 41 (1) : 89-94

Fricker, H.A.; Popov, S.; Allison, I.; Young, N. 2001 : Distribution of marine ice beneath the Amery Ice Shelf. Geophysical Research Letters 28 : 2241-2244.

Fricker, H.A.; Warner, R.C.; Allison, I. 2000 : Mass balance of the Lambert Glacier-Amery Ice Shelf system, East Antarctica: a comparison of computed balance fluxes and measured fluxes. Journal of Glaciology, 46 : 561-570.

Guy-Ohlson, D. 1996 : Green and blue-green algae. 7B - Prasinophycean Algae In (eds, Jansonius, J; McGregor, D.C) Palynology: principles and applications; American Association of Stratigraphic Palynologists Foundation, Vol. 1 : 181-189

Hambrey, M.J. 1991 : Structure and Dynamics of the Lambert Glacier-Amery Ice Shelf System: Implications for the Origin of Prydz Bay Sediments. In Barron, J.;Larsen, B. et al Proc. ODP, Sci. Results, 119: College Station, TX (Ocean Drilling Programme) 61-75.

Hambrey, M. J., Barrett, P. J., Ehrmann, E. H. \& Larsen, B. 1992. Cenozoic sedimentary processes on the Antarctic continental shelf: the record from deep drilling. Zeitschrift für Geomorphologie, Suppl. Vol. 86, 73-99.

Hambrey, M.J.; Ehrmann, W.U.; Larsen, B. 1991 : Cenozoic Glacial Record of the Prydz Bay Continental Shelf, East Antarctica. In Barron, J.;Larsen, B. et al 
Proc. ODP, Sci. Results, 119: College Station, TX (Ocean Drilling Programme) 77-128

Hambrey, M.J.; Ehrmann, W.U.; Larsen, B. 1994 : The Cenozoic Sedimentary

Record of the Prydz Bay Continental Shelf, East Antarctica. Terra Antartica. $1: 399-402$

Hambrey, M.J.; McKelvey, B. 2000 : Neogene fjordal sedimentation on the western margin of the Lambert Graben, East Antarctica. Sedimentology. 47 : 577607.

Hannah, M.J. 1994 : Eocene Dinoflagellates from CIROS-1 Drill Hole, McMurdo Sound, Antarctica Terra Antartica (special issue) 1 (2), 371

Hannah, M.J. 1997 : Climate Controlled Dinoflagellate Distribution in Late Eocene-Earliest Oligocene Strata from CIROS-1 Drillhole, McMurdo Sound Antarctica. Terra Antartica 4 (2) : 73-78

Hannah, M.J. 2005 : The palynology of ODP site 1165, Prydz Bay, East Antarctica: A record of Miocene glacial advance and retreat. Palaeogeography, Palaeoclimatology, Palaeoecology 14 pages.

Hannah, M.J.; Cita, M.B.; Coccioni, R.; Monechi, S. 1997 : The Eocene/Oligocene Boundary at $70^{\circ}$ South, McMurdo Sound, Antarctica Terra Antartica 4 (2) $79-87$

Hannah, M.J.; Wrenn, J.H.; Wilson, G.J.; 1998 : Early Miocene and Quaternary Marine Palynomorphs from Cape Roberts Project CRP-1, McMurdo Sound, Antarctica. Terra Antartica 5 (3) : 527-538

Hannah, M.J.; Wilson, G.J.; Wrenn, J.H. 2000 : Oligocene and Miocene Marine Palynomorphs from CRP-2/2A, Victoria Land Basin, Antarctica Terra Antartica 7 (4) : 503-511

Hannah, M.J.; Wrenn, J.H.; Wilson, G.J. 2001 : Preliminary Report on Early Oligocene and ?Latest Eocene Marine Palynomorphs from CRP-3 Drillhole, Victoria Land Basin, Antarctica Terra Antartica 8 (4) : 383-388

Harland, R.; Pudsey, C.J. 1999 : Dinoflagellate cysts from sediment traps deployed in the Bellingshausen, Weddell and Scotia seas, Antarctica. Marine Micropaleontology. $37: 77-99$

Harland, R.; Pudsey, C.J.; Howe, J,A.; Fitzpatrick M.E.J. 1998 : Recent Dinoflagellate Cysts in a Transect from the Falkland Trough to the Weddell Sea, Antarctica. Palaeontology. 41 (6) : 1093-1131 
Harris, P.T. 2000 : Sedimentological Signatures of Sub-Ice-Shelf Circulation: An example from Vincennes Bay, East Antarctica. Papers and Proceedings of the Royal Society of Tasmania. $133:$ 57-62.

Harris, P.T.; O’Brien, P.E.; Quilty, P.G.; Taylor, F.; Domack, E.; DeSantis, L.;

Raker, B. 1997 : Prydz Bay. Post Cruise Report - Vincennes Bay, Prydz Bay and Mac.Robertson Shelf. AGSO Cruise 186 : 34-63

Harris, P.T.; O’Brien, P.E. 1998 : Bottom currents, sedimentation and ice-sheet retreat facies successions on the MacRobertson shelf, East Antarctica. Marine Geology. 151 : 47-72.

Harris, P.T.; Taylor, F.; Pushina, Z.; Leitchenkov, G.; O’Brien, P.E.; Smirnov, V. 1998 : Lithofacies distribution in relation to the geomorphic provinces of Prydz Bay, East Antarctica. Antarctic Science 10 : 227-235.

Harwood, D.M.; Levy, R.H. 2000a : The McMurdo Erratics: Introduction and Overview. In (eds Stilwell, J.D.; Feldmann, R.M.) Paleobiology and Paleoenvironments of Eocene Rocks; Antarctic Research Series, Vol 76: 1-18 Head, M.J. 1996 : Modern Dinoflagellate Cysts and their Biological Affinities. In (eds, Jansonius, J; McGregor, D.C) Palynology: principles and applications; American Association of Stratigraphic Palynologists Foundation, Vol. 3. 1197-1248.

Hemer, M.; Harris, P.T. 2004: Sediments collected from beneath the Amery Ice Shelf, East Antarctica, document sub-ice-shelf circulation of water and sediments throughout the Holocene. FRISP Report No. 15 : 61-66.

Holland, D.M.; Jenkins, A. 2001 : Adaptation of an Isopycnic Coordinate Ocean Model for the Study of Circulation beneath Ice Shelves. American Meteorolological Society. 129 : 1905-1927.

Jansonius, J.; McGregor D.C. 1996 Introduction Palynology: Principles and applications American Association of Stratigraphic Palynologists Foundation Vol : 1 1-10

Kemp, E.M. 1972 : Reworked Palynomorphs from the West Ice Shelf Area, East Antarctica, and their possible Geological and Palaeoclimatological Significance. Marine Geology 13: 145-157

Kemp, E.M. 1975 : Palynology of Leg 28 drill Sites, Deep Sea Drilling project. In (eds Hayes, D.E.; Frakes, L.A. et al ) Initial Reports of the Deep Sea Drilling project, Vol. 28 : 599-608. 
Leventer, A. 2003: Particulate Flux from Sea Ice in Polar Waters. In (eds Thomas, D.N.; Dieckmann, G.S.) Sea Ice: An Introduction to its Physics, Chemistry, Biology and Geology. Blackwell, UK. 333-372

Levy, R.H.; Harwood, D.M. 2000b : Tertiary Marine Palynomorphs from the McMurdo Sound Erratics, Antarctica. In (eds Stilwell, J.D.; Feldmann, R.M.) Paleobiology and Paleoenvironments of Eocene Rocks; Antarctic Research Series, Vol 76: 183-242

Lindgren, S. 1981 : Remarks on the taxonomy, botanical affinities and distribution of leiospheres. Stockh. Contr. Geol. 38 (1) : 10-20

Lizotte, M.P. 2001: The contributions of sea ice algae to Antarctic marine primary production. American Zoologist 41 (1) : 57-73.

Lizotte M.P. 2003: The Microbiology of Sea Ice. In (eds Thomas, D.N.; Dieckmann, G.S.) Sea Ice: An Introduction to its Physics, Chemistry, Biology and Geology. Blackwell, UK.

McMinn, A.; Scott, F.J. 2005 : Dinoflagellates. In (eds Scott F.J.; Marchant, H.J.) Antarctic Marine Protists ABRS, Canberra, AAD, Hobart

MacPhail, M.K.; Truswell, E.M. 2004 : Palynology of Site 1166, Prydz Bay, East Antarctica. In (eds Cooper, A.K.; O’Brien, P.E.; Richter, C.) Proceedings of the Ocean Drilling Program, Scientific Results. Vol. 188

MacPhail, M.K.; Truswell, E.M. 2004 : Palynology of Neogene Slope and Rise Deposits from ODP Sites 1165 and 1167, East Antarctica. In (eds Cooper, A.K.; O’Brien, P.E.; Richter, C.) Proceedings of the Ocean Drilling Program, Scientific Results. Vol. 188

Marret, F.; de Vernal, A. 1997 : Dinoflagellate cyst distribution in surface sediments of the southern Indian Ocean. Marine Micropaleontology. 29 : $367-392$

Mishra, D.C.; Chandra Sekhar D.V.; Venkata Raju, D.Ch.; Vijaya Kumar, V. 1999: Crustal structure based on gravity-magnetic modelling constrained from seismic studies under Lambert Rift, Antarctica and Godavari and Mahanadi rifts, India and their interrelationship. Earth and planetary science letters $172(3 \& 4): 287-300$

Mudie, P.J. 1992 : Circum-Arctic Quaternary and Neogene Marine Palynofloras: Paleoecology and Statistical Analysis. In (eds Head, M.J.; Wrenn, J.H.) 
Neogene and Quaternary Dinoflagellate Cysts and Acritarchs: American

Association of Stratigraphic Palynologists Foundation. Dallas : 347-390.

Mudie, P.J.; Harland, R. 1996 : Aquatic Quaternary. In (eds Jansonius, J.;

McGregor, D.C.) Palynology: principles and applications; American

Association of Stratigraphic Palynologists Foundation, Vol. 2. 843-877

Mudie, P.J.; Rochon, A. 2001 : Distribution of dinoflagellate cysts in the Canadian

Arctic marine region. Journal of Quaternary Science 16 (7) : 603-620.

Nunes Vas, R.A.; Lennon, G.W. 1996: Physical oceanography of the Prydz Bay region of Antarctic waters. Deep-Sea Research 1, 43 (5) : 603-641

O’Brien, P.E. 1994 : Morphology and Late Glacial History of Prydz Bay, Antarctica, Based on Echo Sounder Data. Terra Antartica. 1 : 403-405

O’Brien, P.E.; Borisova, I.; Quilty, P.G.; Bardsley, T.M.; Constable, A.; Harris. P.T. 2003 : History of the Southern Ocean and Antarctic continental shelf - the ANARE contribution. In Australian Antarctic Science first 50 years of ANARE. (Eds Marchant, H.J.; Lugg, D.J.; Quilty, P.G.) Australian Antarctic Division 139-163

O’Brien, PE.; Cooper, A.K.; Florindo, F.; Handwerger D.A. Lavelle, M., Passchier, S., Pospichal, J.J., Quilty, P.G., Richter, C., Theissen, K.M., and Whitehead, J.M.et al. 2004 : Prydz Channel Fan and the History of Extreme Ice Advances in Prydz Bay. In Proceedings of the Ocean Drilling Program, Scientific Results. (Eds: Cooper, A.K.; O’Brien, P.E., and Richter, C.) Volume 188

O’Brien, PE.; Cooper, A.K.; Florindo, F.; Handwerger D.A. Lavelle, M., Passchier, S., Pospichal, J.J., Quilty, P.G., Richter, C., Theissen, K.M., and Whitehead, J.M. et al. 2001 : Legg 188 Summary: Prydz Bay-Cooperation Sea, Antarctica. In Proceedings of the Ocean Drilling Program, Scientific Results. (Eds: Cooper, A.K.; O’Brien, P.E., and Richter, C.) Volume 188 O’Brien, P.E.; De Santis, L.; Harris, P.T.; Domack, E.; Quilty, P.G. 1999 : Ice shelf grounding zone features of western Prydz Bay, Antarctica: sedimentary processes from seismic and sidescan images. In Antarctic Science (eds Walton, D.W.H.; Thomson, M.R.A.; Mobbs S.D.) Blackwell Scientific Publications 11 : 78-91. 
O’Brien, P.E.; Franklin, D.; O’Loughlin, M. 1993 Procedure to Deploy and Recover Gravity Corer. Post Cruise Report - Prydz Bay \& Mac.Robertson Shelf, Antarctica, January-March, 1993 : AGSO cruise 901 page 38

O’Brien, P.E.; Harris, P.T.; Quilty, P.G.; Taylor, F.; Wells, P. 1995 : Prydz Channel Fan Post Cruise Report - Prydz Bay, Mac.Robertson Shelf and Kergueleun Plateau AGSO Cruise 149 : 25-32

O’Brien, P.E.; Harris, P.T. 1996 : Patterns of Glacial Erosion and Deposition in Prydz Bay and the Past Behaviour of the Lambert Glacier. Papers and Proceedings of the Royal Society of Tasmania 130:79-85.

O’Brien, P.E.; Leitchenkov, G., 1997 : Deglaciation of Prydz Bay, East Antarctica, based on echo sounder and topographic features. In Geology and Seismic Stratigraphy of the Antarctic Margin (Pt.2) (eds. Barker, P.F.; Cooper, A.K.) Am. Geophys. Union Antarct. Res. Ser., 71 : 109-125

Passchier, S.; O’Brien, P.E.; Damuth, J.E.; Januszczak, N.; Handwerger, D.A.; Whitehead, J.M. 2003 : Pliocene-Pleistocene glaciomarine sedimentation in eastern Prydz Bay and development of the Prydz trough-mouth fan, ODP Sites 1166 and 1167, East Antarctica. Marine Geology. 199 : 279-305. Proceedings of the Ocean Drilling Program, Scientific Results Volume 188 (Eds) Cooper, A.K., O’Brien, P.E., and Richter, C. Web Publication: 30 July 2004

Pickering, K.T.;Hiscott, R.N.;HeinF.J. 1989 : Deep marine environments: Clastic sedimentation and techtonics. Unwin Hyman, London p 416

Pushina, Z.V.; Kolobov, D.D.; Druzhinina, N.I. 1997 : Biostratigraphy and Paleoecology of the Bottom Sediments in Pryz Bay. In (ed Ricci, C.A) The Antarctic Region: Geological Evolution and Processes Proceedings of the VII International Symposium on Antarctic Earth Sciences, Siena, 1995. Terra Antartica 869-874

Quilty P.G., 1985. Distribution of foraminiferids in sediments of Prydz Bay, Antarctica. Spec. Publ. S. Aust. Dep. Mines Energy 5, 329-340

Raine, J.I.; Askin, R.A.; Crouch, E.M.; Hannah, M.J.; Levy, R.H.; Wrenn, J.H. 1997: Palynomorphs. In (eds Hannah, M.J.; Raine, J.I.) Southern Ocean late Creataceous/Early Cenozoic biostratigraphic datums. Institute of Geological \& Nuclear Sciences science report 97/4 25-33 
Rochon, A.; de Vernal, A.; Turon, J-L.; Matthiessen, J.; Head, M.J. 1999 :

Distribution of Recent Dinoflagellate Cysts in surface Sediments from the North Atlantic Ocean and Adjacent Seas in Relation to Sea-surface Parameters. American Association of Stratigraphic Palynologists Foundation Contributions Series. Number 35

Smith, N.;Dong, Z.; Kerry, K.;Wright, S. 1984 : Water masses and circulation in the region of Prydz Bay, Antarctica. Deep-Sea Research, 31 : 1121-1147

Smith, N.; Treguer, P. 1994 : Physical and chemical oceanography in the vicinity of Prydz Bay, Antarctica. In Southern Ocean Ecology: The BIOMASS Perspective (Eds El-Sayed, S.Z.) Cambridge University Press 25-43.

Stagg, H.M.J. 1983 : The Structure and Origin of Prydz Bay and MacRobertson Shelf, East Antarctica. Tectonophysics. $114: 315-340$.

Stancliffe, R.P.W. 1996 : Miscellaneous. 13D-Microforaminiferal Linings. In (eds, Jansonius, J; McGregor, D.C) Palynology: principles and applications; American Association of Stratigraphic Palynologists Foundation, Vol. 1. 373-379.

Stoecker, D.K.; Gustafson, D.E.; Black, M.M.D.; Baier, C.T. 1998: Population Dynamics of Microalgae in the Upper Land-fast Sea Ice at a Snow-free Location. Journal of Phycology 34 : 60-69.

Stover, L.E.; Brinkhuis, H.; Damassa, S.P.; de Verteuil, L.; Helby, R.J.; Monteil, E.; Partridge, A.D.; Powell, A.J.; Riding, J.B.; Smelror, M.; Williams, G.L. 1996 : Mexozoic-Tertiary Dinoflagellates, Acritarchs and Prasinophytes. In (eds, Jansonius, J; McGregor, D.C) Palynology: principles and applications; American Association of Stratigraphic Palynologists Foundation, Vol. 2. 641-750.

Strother, P. K. 1996 : Acritarchs. In (eds, Jansonius, J; McGregor, D.C) Palynology: principles and applications; American Association of Stratigraphic Palynologists Foundation, Vol. 1. 81-106.

Tappan, H. 1980 : The Paleobiology of Plant Protists. Freeman and Co. USA Taylor, F,; Leventer, A. 2003 : Late Quaternary palaeoenvironments in Prydz Bay, East Antarctica: interpretations from marine diatoms. Antarctic Science 15 (4) : 512-513 
Taylor, F.; McMinn, A.; Franklin, D. 1997 : Distribution of diatoms in surface sediments of Prydz Bay, Antarctica. Marine Micropaleontology 32 : 209229

Truswell, E.M. 1982 : Palynology of seafloor samples collected by the 1911-14 Australasian Antarctic Expedition: implications for the geology of coastal East Antarctica. Journal of the Geological Society of Australia 29: 343-356

Truswell, E.M. 1982: Geological Implications of Recycled Palynomorphs in Continental Shelf Sediments Around Antarctica. In Antarctic Earth Sciences (Eds Oliver R.L.; James, P.R.; Jago, J.B.) Cambridge University Press 394399.

Truswell, E.M. 1983 : Recycled Cretaceous and Tertiary Pollen and Spores in Antarctic Marine Sediments: A Catalogue. Palaeontographica Abt. B 186 : 121-174

Truswell, E.M. 1986 Palynology In: Barrett, P.J. (ed) Antarctic Cenozoic history from the MSSTS-1 drillhole, McMurdo Sound, DSIR Bulletin 237 : 131-134.

Truswell, E.M.; Drewry, D.J. 1984 Distribution and Provenance of Recycled Palynomorphs in Surficial Sediments of the Ross Sea, Antarctica. Marine Geology, 59 : 187-214

Truswell, E.M.; Dettmann, M.E.; O’Brien, P.E. 1999 : Mesozoic palynofloras from the MacRobertson shelf, East Antarctica: geological and phytogeographic implications. Antarctic Science 11 (2) : 239-255

Villa, G.; Perasico, D.; Bonci, M.C.; Lucchi, R.G.; Morigi, C.; Rebesco, M. 2003: Biostratigraphic characterization and Quaternary microfossil palaeoecology in sediment drifts west of the Antarctic Peninsula - implications for cyclic glacial-interglacial deposition. Palaeogeography, Palaeoclimatology, Palaeoecology 198 : 237-263.

Wellman, P.; Tingey, R.J. 1981 : Glaciation, erosion and uplift over part of East Antarctica. Nature 291 : 142-144.

Williams, M.J.M.; Grosfeld, K.; Warner, R.C.; Gerdes, R.; Determann, J. 2001 : Ocean circulation and ice-ocean interaction beneath the Amery Ice Shelf, Antarctica. Journal of Geophysical Research 106 : 22,383-22,399.

Wilson, G.J. 1989 : Marine palynology. In (ed Barrett, P.J.) Antarctic Cenozoic history from the CIROS-1 drillhole, McMurdo Sound. DSIR Bulletin 245: 129-133 
Wong, A.P.S.; Bindoff, N.L.; Forbes, A. 1998 : Ocean-Ice Shelf Interaction and Possible Bottom Water Formation in Prydz Bay, Antarctica. In Ocean, Ice, and Atmosphere: Interactions at the Antarctic Continental Margin (Eds Jacobs, S.J.\& Weiss, R.F.) Antarctic Research Series 75 : 173-187.

Wrenn, J.H.; Hannah, M.J.; Raine, J.I. 1998 : Diversity and Palaeoenvironmental Significance of Late Cainozoic Marine Palynomorphs from the CRP-1 Core, Ross Sea, Antarctica. Terra Antartica 5 (3) : 553-570.

Wrenn, J.H.;Hart, G.F. 1988. Paleogene dinoflagellate cyst biostratigraphy of Seymour Island, Antarctica. In (eds Feldmann, R.M.; Woodburne, M.O) Geology and Paleontology of Seymour Island, Antarctic Peninsula.

Geological Society of America Memoir 169:321-448 
APPENDIX A

The distribution of marine palynomorphs in surface sediments of Prydz Bay, Antarctica MASTER SPREADSHEET

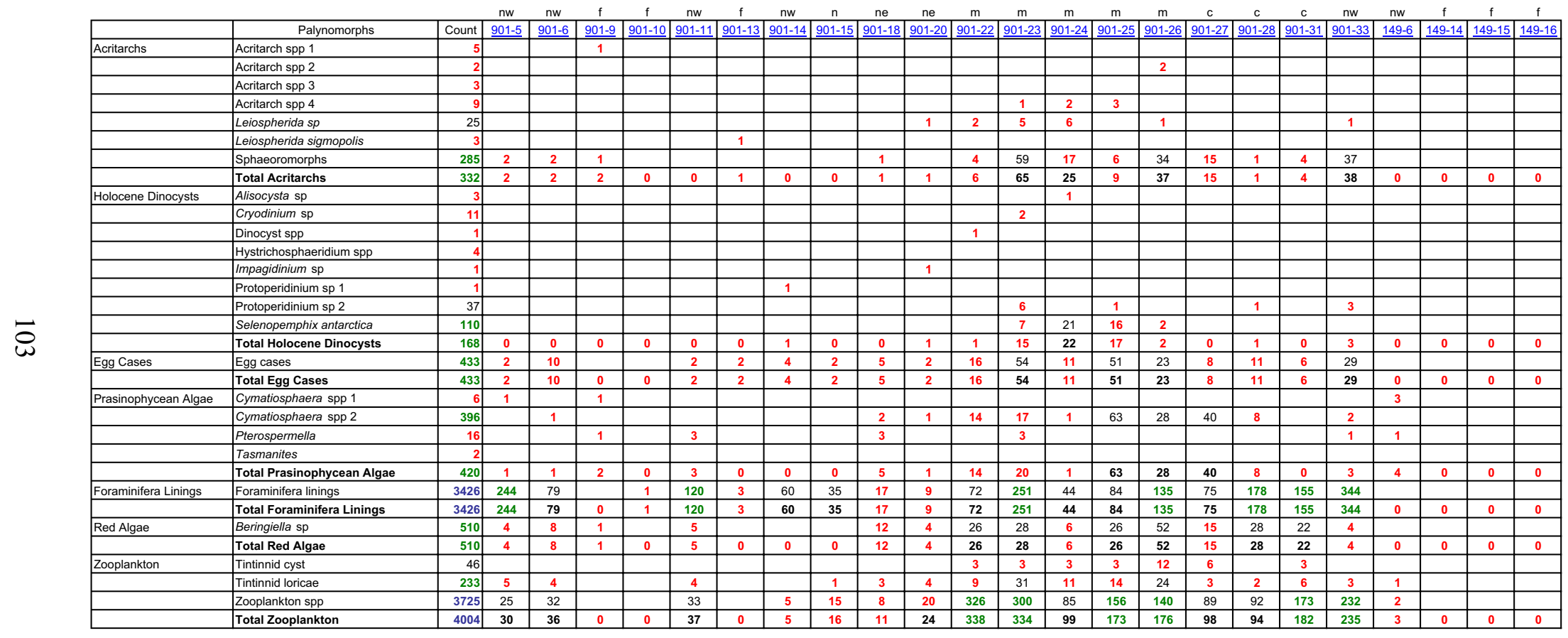


APPENDIX A The distribution of marine palynomorphs in surface sediments of Prydz Bay, Antarctica MASTER SPREADSHEET

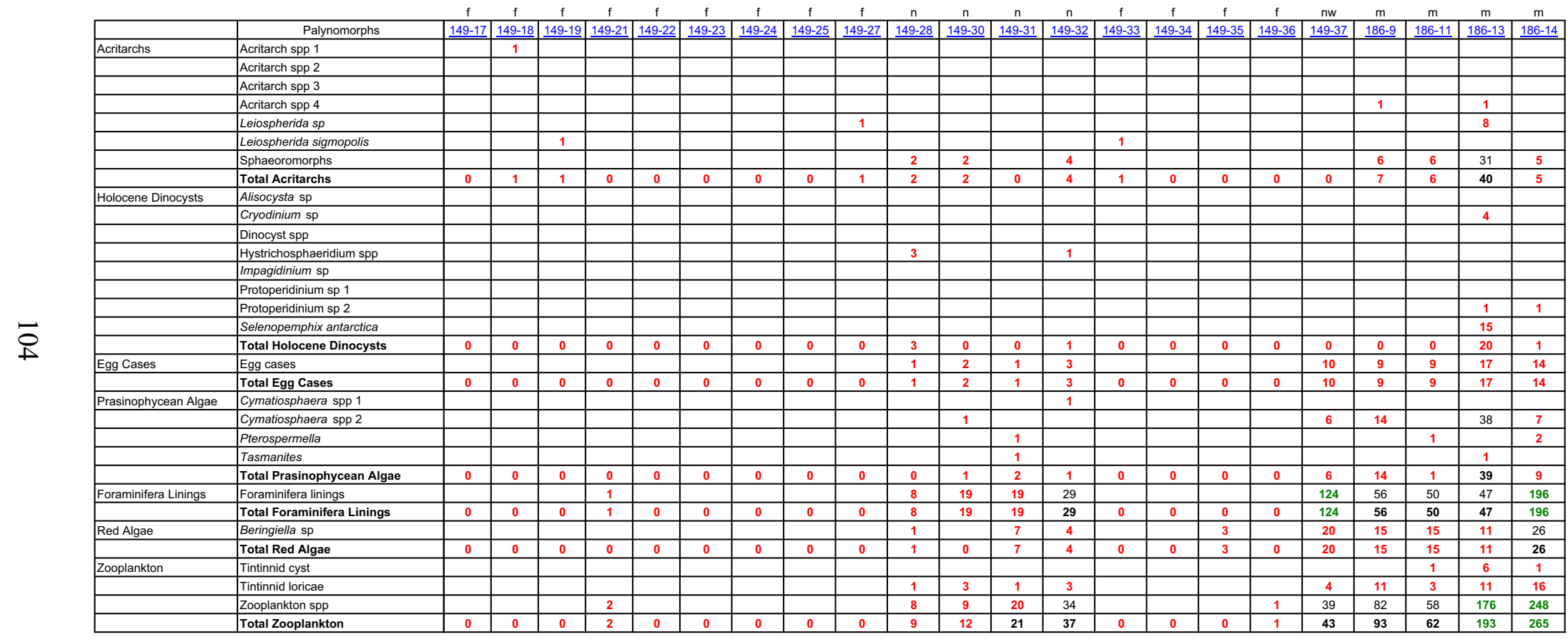


APPENDIX A The distribution of marine palynomorphs in surface sediments of Prydz Bay, Antarctica MASTER SPREADSHEET

\begin{tabular}{|c|c|c|c|c|c|c|c|c|c|c|c|c|c|c|}
\hline & $\begin{array}{c}\text { Palynomorphs } \\
\end{array}$ & $186-15$ & $186-16$ & $186-17$ & $186-18$ & $186-19$ & $186-21$ & $186-22$ & $186-26$ & $186-27$ & $186-28$ & $1866-29$ & $186-31$ & $186-32$ \\
\hline Acritarchs & $\begin{array}{l}\text { Accitiarch spp } 1 \\
\text { Acritach spp } 2\end{array}$ & & & & & & & & & & & & & \\
\hline & 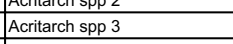 & & & & & & & 3 & & & & & & \\
\hline & 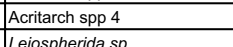 & & & & 1 & & & & & & & & & \\
\hline & Leiosphenridas sigmopolis & & & & & & & & & & & & & \\
\hline & $\begin{array}{l}\text { Sphhaeoromorphs } \\
\text { Totat Acritachs }\end{array}$ & $\frac{4}{4}$ & $\frac{7}{77}$ & $\frac{7}{77}$ & 1 & 0 & $\frac{12}{12}$ & $\frac{14}{17}$ & $\frac{1}{1}$ & $\frac{1}{1}$ & 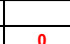 & 3 & 0 & 0 \\
\hline Holocene Dinocysts & \begin{tabular}{|l} 
Alisoconsta sis \\
As
\end{tabular} & & & & & & & 5 & & 1 & & & & $\frac{1}{1}$ \\
\hline & Dinocyst spp & & & & & & & & & & & & & \\
\hline & $\begin{array}{l}\text { Hystrichoshnearidium spp } \\
\text { Impagidiuim sp }\end{array}$ & & & & & & & & & & & & & \\
\hline & \begin{tabular}{|l} 
Protoperidinium sp 1 \\
Prototoridium sp
\end{tabular} & & & & & & & 24 & & & & & & \\
\hline & 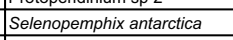 & & & 1 & & & & & & & & & & \\
\hline Egg Cases & $\begin{array}{l}\text { Total Holocene Dinocysts } \\
\text { Eqag cases }\end{array}$ & $\frac{0}{13}$ & $\frac{0}{18}$ & $\frac{1}{16}$ & 0 & $\frac{0}{7}$ & $\frac{0}{11}$ & $\frac{77}{48}$ & $\frac{0}{10}$ & $\frac{1}{1}$ & 0 & 0 & 0 & 1 \\
\hline & $\begin{array}{l}\text { Legsaceses Cases } \\
\text { Total Egg Case }\end{array}$ & 13 & 18 & $\frac{10}{16}$ & 3 & $\frac{1}{7}$ & 11 & $\frac{40}{48}$ & 10 & $\frac{1}{1}$ & 1 & $\frac{1}{1}$ & 0 & 0 \\
\hline $\begin{array}{l}\text { Prasinophycean Algae } \\
\end{array}$ & \begin{tabular}{|l|} 
Cymatiosphaera spp 1 \\
Cymatioshhoarar spp 2
\end{tabular} & 74 & 2 & 3 & 11 & 8 & 45 & 8 & 1 & & 1 & & & \\
\hline & \begin{tabular}{|l|} 
Pterosspermella \\
Touspinel
\end{tabular} & & & & & & & & & & & & & \\
\hline & $\begin{array}{l}\text { Tostmames Prasinophycean Algae } \\
\end{array}$ & 74 & 2 & 3 & 11 & 8 & 45 & 8 & 1 & 0 & 1 & 0 & 0 & 0 \\
\hline Foraminifera Linings & 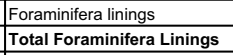 & $\begin{array}{l}\frac{82}{82} \\
\end{array}$ & $\begin{array}{l}254 \\
254 \\
254\end{array}$ & $\begin{array}{l}24 \\
24 \\
\end{array}$ & $\frac{60}{60}$ & $\frac{78}{78}$ & $\frac{39}{39}$ & 296 & $\frac{115}{115}$ & $\frac{11}{11}$ & $\frac{4}{4}$ & 8 & 0 & 0 \\
\hline Red Algae & \begin{tabular}{|l|l|} 
Beringiella sp \\
Total Red Alapa
\end{tabular} & 9 & $\frac{18}{18}$ & 99 & 3 & $\frac{11}{11}$ & 9 & $\begin{array}{ll}91 \\
911\end{array}$ & 6 & $\frac{3}{3}$ & $\frac{6}{6}$ & 2 & $\overline{0}$ & 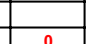 \\
\hline Zooplanktón & $\begin{array}{l}\text { ITtatal and Algae } \\
\text { Trintinnid Ayst }\end{array}$ & 9 & $\frac{18}{1}$ & $\frac{9}{2}$ & 3 & 11 & 9 & 91 & & 3 & & 2 & 0 & \\
\hline & Timininid oforicae & 5 & 10 & 12 & & 3 & 8 & 8 & 9 & -5 & & & & \\
\hline & $\frac{\text { Zooplankton spp }}{\text { Total Zooplankton }}$ & 106 & $\frac{302}{313}$ & 114 & 65 & 130 & $\frac{53}{62}$ & $\frac{370}{378}$ & $\frac{141}{150}$ & $\frac{9}{9}$ & $\frac{25}{25}$ & $\overline{0}$ & & 0 \\
\hline
\end{tabular}


APPENDIX A

The distribution of marine palynomorphs in surface sediments of Prydz Bay, Antarctica MASTER SPREADSHEET

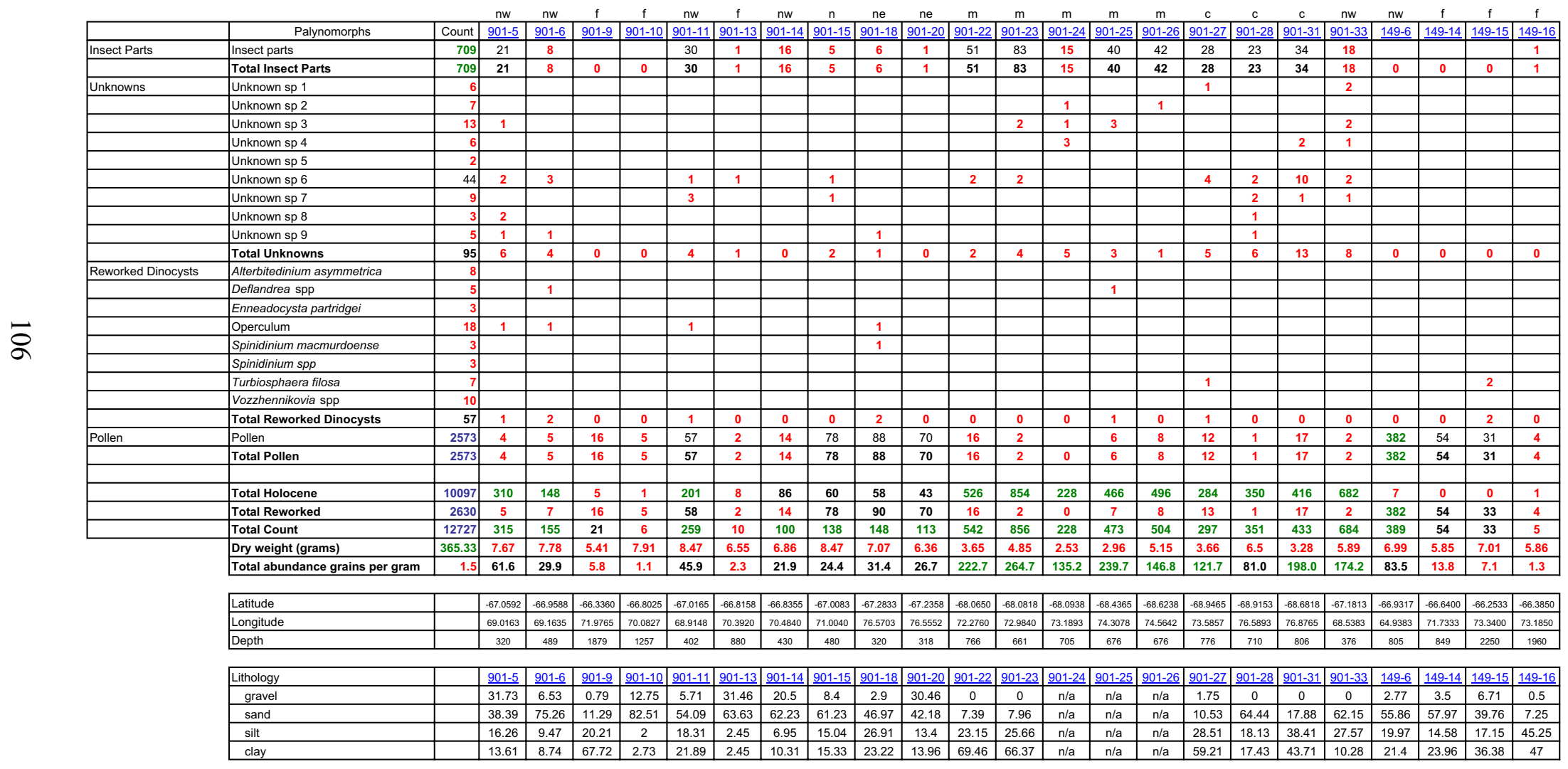


APPENDIX A

The distribution of marine palynomorphs in surface sediments of Prydz Bay, Antarctica MASTER SPREADSHEET

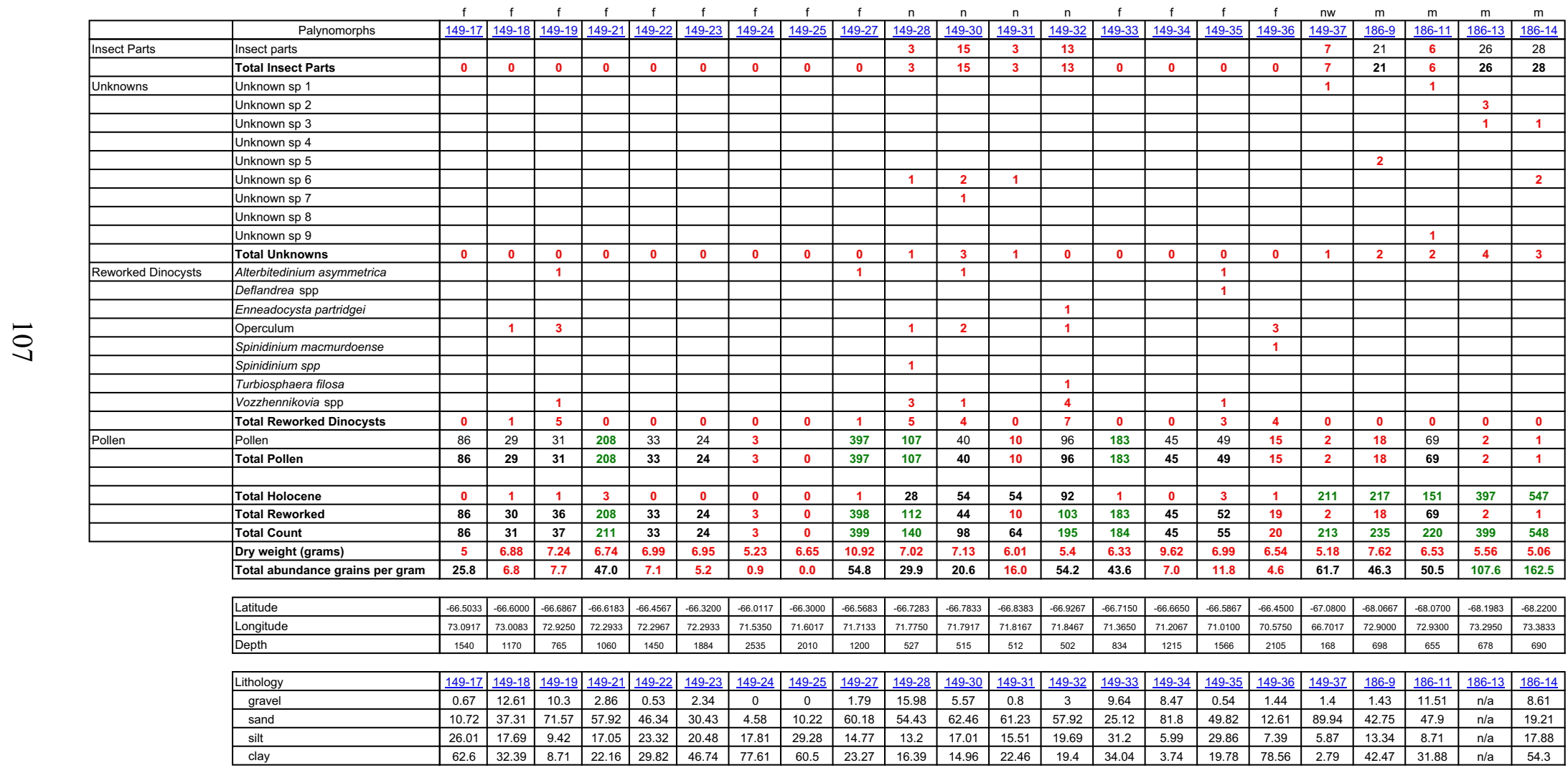


APPENDIX A

The distribution of marine palynomorphs in surface sediments of Prydz Bay, Antarctica MASTER SPREADSHEET

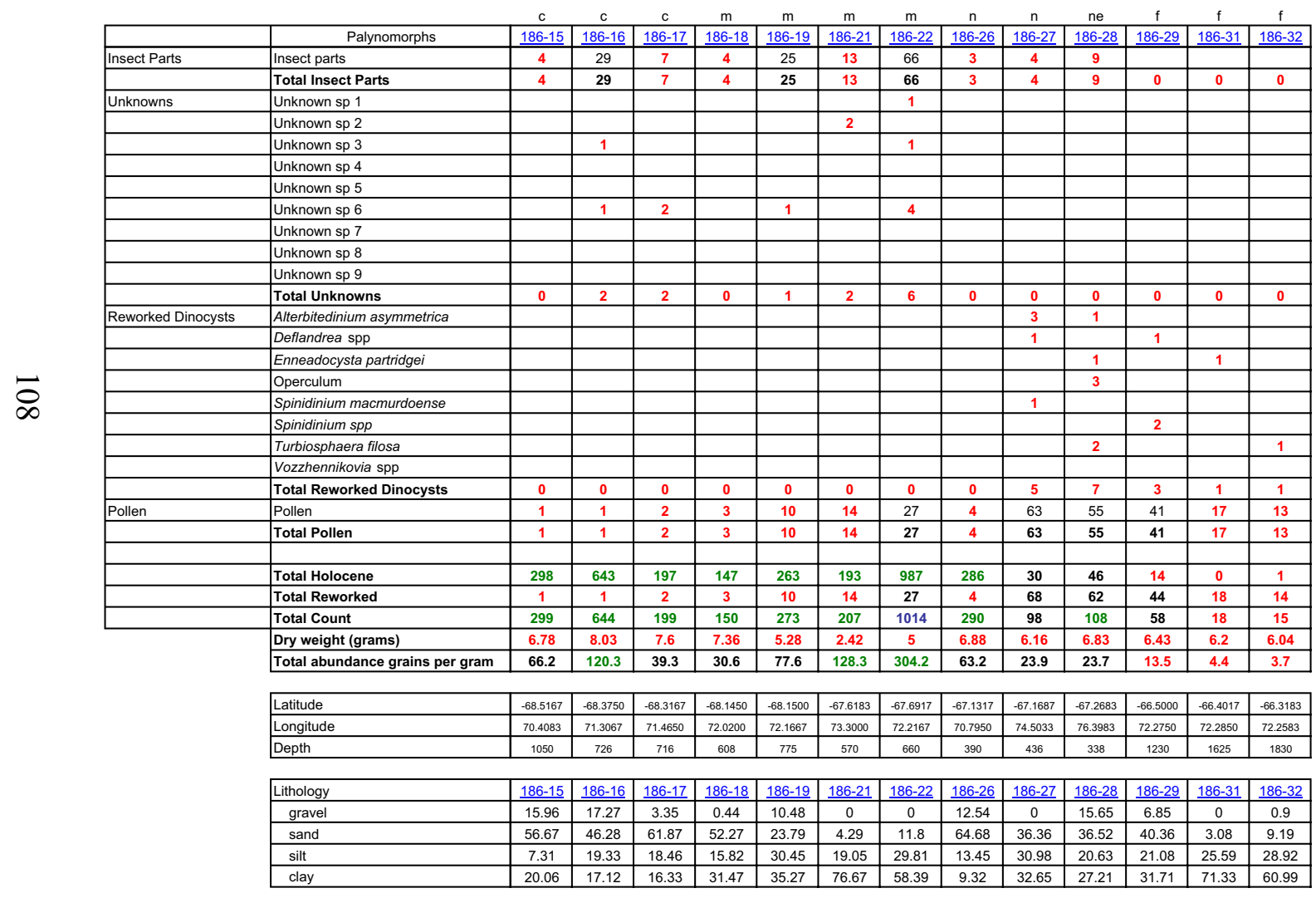




\begin{tabular}{|c|c|c|c|}
\hline Sample & 901-5 & & \\
\hline Lithology & $\begin{array}{ll}\text { gravel } & 31.73 \\
\text { sand } & 38.39 \\
\text { silt } & 16.26 \\
\text { clay } & 13.61\end{array}$ & $\begin{array}{l}\text { Bathymetry } \\
\text { Latitude } \\
\text { Longitude }\end{array}$ & $\begin{array}{l}320 \mathrm{~m} \\
-67.05916 \\
69.01633\end{array}$ \\
\hline
\end{tabular}

\begin{tabular}{lll}
\multicolumn{1}{c}{ Palynomorphs } & Count & \\
Unknowns & Unknown sp. 3 & 1 \\
& Unknown sp. 6 & 2 \\
& Unknown sp. 8 & 2 \\
& Unknown sp. 9 & 1 \\
Acritarchs & Sphaeoromorphs & 2 \\
Dinoflagellates & Operculum & 1 \\
Egg Cases & Egg cases & 2 \\
Pollen & Pollen & 4 \\
Prasinophyte algae & Cymatiosphaera sp. 1 & 1 \\
Red Algae & Beringiella sp. & 4 \\
Zooplankton & Tintinnid loricae & 5 \\
& Zooplankton spp. & 25 \\
Foraminiferan linings & & 244 \\
Insect parts & & 21 \\
looked at 901/5 - 901/5-2 - 901/5-2b & Total Count & 315
\end{tabular}

\section{Sample 901-6}

\begin{tabular}{lllll}
\hline Lithology & gravel & 6.53 & Bathymetry & $489 \mathrm{~m}$ \\
& sand & 75.26 & Latitude & -66.95883 \\
& silt & 9.47 & Longitude & 69.1635 \\
& clay & 8.74 & & \\
& nat & & &
\end{tabular}

\begin{tabular}{lll}
\multicolumn{1}{c}{ Palynomorphs } & Count & \\
Unknowns & Unknown sp. 6 & 3 \\
& Unknown sp. 9 & 1 \\
Acritarchs & Sphaeoromorphs & 2 \\
Dinoflagellates & Deflandrea spp. & 1 \\
& Operculum & 1 \\
Prasinophyte algae & Cymatiosphaera sp. 2 & 1 \\
Egg Cases & Egg cases & 10 \\
Pollen & pollen & 5 \\
Red Algae & Beringiella sp. & 8 \\
Zooplankton & Tintinnid loricae & 4 \\
& Zooplankton spp. & 32 \\
Others & Foraminiferan linings & 79 \\
& Insect parts & 8 \\
& & Total Count \\
\end{tabular}




\begin{tabular}{lllll}
\hline Sample & $\mathbf{9 0 1 - 9}$ & & \\
\hline Lithology & gravel & 0.79 & Bathymetry & $1879 \mathrm{~m}$ \\
& sand & 11.29 & Latitude & -66.336 \\
& silt & 20.21 & Longitude & 71.9765 \\
& clay & 67.72 & & \\
& & & &
\end{tabular}

\begin{tabular}{lll} 
& \multicolumn{1}{c}{ Palynomorphs } & \multicolumn{1}{c}{ Count } \\
Acritarchs & Acritarch spp. 1 & 1 \\
Red Algae & Sphaeoromorphs & 1 \\
Pollen & Beringiella sp. & 1 \\
& Pollen & 16 \\
Prasinophycean Algae & Cymatiosphaera sp. 1 & 1 \\
& Pterospermella & 1 \\
&
\end{tabular}

\begin{tabular}{lllll}
\hline Sample & $\mathbf{9 0 1 - 1 0}$ & & \\
\hline Lithology & gravel 12.75 & Bathymetry & $1257 \mathrm{~m}$ \\
& sand & 82.51 & Latitude & -66.8025 \\
& silt & 2 & Longitude & 70.08266 \\
& clay & 2.73 & & \\
& & & &
\end{tabular}

\section{Palynomorphs Count}

\begin{tabular}{lcr} 
Pollen & Pollen & 5 \\
Foraminiferan linings & 1 \\
& & \\
\cline { 2 - 3 } & Total Count & 6 \\
\hline
\end{tabular}




\begin{tabular}{lllll}
\hline Sample & 901-11 & & \\
\hline Lithology & gravel & 5.71 & Bathymetry & $402 \mathrm{~m}$ \\
& sand & 54.09 & Latitude & -67.0165 \\
& silt & 18.31 & Longitude & 68.91483 \\
& clay & 21.89 & & \\
& & & &
\end{tabular}

\begin{tabular}{lll}
\multicolumn{1}{c}{ Palynomorphs } & Count & \\
Unknowns & Unknown sp. 6 & 1 \\
& Unknown sp. 7 & 3 \\
Dinoflagellates & Operculum & 1 \\
Egg Cases & Egg cases & 2 \\
Prasinophycean Algae & Pterospermella & 3 \\
Pollen & Pollen & 57 \\
Red Algae & Beringiella sp & 5 \\
Zooplankton & Tintinnid loricae & 4 \\
& Zooplankton spp. & 33 \\
Foraminiferan linings & & 120 \\
Insect parts & & 30 \\
& &
\end{tabular}

\section{Sample 901-13}

\begin{tabular}{lclll}
\hline Lithology & gravel 31.46 & Bathymetry & $880 \mathrm{~m}$ \\
& sand & 63.63 & Latitude & -66.81583 \\
silt & 2.45 & Longitude & 70.392 \\
clay & 2.45 & & \\
& cla & & &
\end{tabular}

\section{Palynomorphs Count}

\begin{tabular}{|c|c|c|}
\hline Unknowns & Unknown sp. 6 & 1 \\
\hline Egg Cases & Egg cases & 2 \\
\hline \multirow{4}{*}{$\begin{array}{l}\text { Pollen } \\
\text { Acritarch } \\
\text { Foraminiferan linings } \\
\text { Insect parts }\end{array}$} & Pollen & 2 \\
\hline & Sigmopollis & 1 \\
\hline & & $\begin{array}{l}3 \\
1\end{array}$ \\
\hline & & 10 \\
\hline
\end{tabular}




\begin{tabular}{lllll}
\hline Sample & $\mathbf{9 0 1 - 1 4}$ & & \\
\hline Lithology & gravel & 20.5 & Bathymetry & $430 \mathrm{~m}$ \\
& sand & 62.23 & Latitude & -66.8355 \\
& silt & 6.95 & Longitude & 70.484 \\
clay & 10.31 & & \\
& & & &
\end{tabular}

\begin{tabular}{|c|c|c|}
\hline Palynomorphs & Count & \\
\hline Dinoflagellates & Protoperidinium sp. 1 & 1 \\
\hline Egg Cases & Egg cases & 4 \\
\hline Pollen & Pollen & 14 \\
\hline Zooplankton & Zooplankton sp. & 5 \\
\hline \multirow{3}{*}{$\begin{array}{l}\text { Foraminiferan linings } \\
\text { Insect parts }\end{array}$} & & 60 \\
\hline & & 16 \\
\hline & Total Count & 100 \\
\hline
\end{tabular}

\section{Sample 901-15}

\begin{tabular}{|c|c|c|c|}
\hline Lithology & $\begin{array}{lc}\text { gravel } & 8.4 \\
\text { sand } & 61.23 \\
\text { silt } & 15.04 \\
\text { clay } & 15.33\end{array}$ & $\begin{array}{l}\text { Bathymetry } \\
\text { Latitude } \\
\text { Longitude }\end{array}$ & $\begin{array}{l}480 \mathrm{~m} \\
-67.0083 \\
71.004\end{array}$ \\
\hline
\end{tabular}

\section{Palynomorphs Count}

\begin{tabular}{|c|c|c|}
\hline \multirow{2}{*}{\multicolumn{3}{|c|}{$\overline{\text { Unknown sp. } 6}$}} \\
\hline & & \\
\hline Unknowns & Unknown sp. 7 & 1 \\
\hline Pollen & Pollen & 78 \\
\hline Egg Cases & Egg Cases & 2 \\
\hline \multirow[t]{2}{*}{ Zooplankton } & Tintinnid loricae & 1 \\
\hline & Zooplankton sp. & 15 \\
\hline \multirow{3}{*}{$\begin{array}{l}\text { Foraminiferan linings } \\
\text { Insect parts }\end{array}$} & & 35 \\
\hline & & 5 \\
\hline & & 138 \\
\hline
\end{tabular}




\section{Samples 901-18}

\begin{tabular}{lllll}
\hline Lithology & gravel & 2.9 & Bathymetry & $320 \mathrm{~m}$ \\
& sand & 46.97 & Latitude & -67.28333 \\
& silt & 26.91 & Longitude & 76.57033 \\
clay & 23.22 & &
\end{tabular}

\begin{tabular}{lll}
\multicolumn{1}{c}{ Palynomorphs } & Count & \\
Unknowns & Unknown sp. 9 & 1 \\
Acritarchs & Sphaeoromorphs & 1 \\
Dinoflagellates & Spinodinium macmurdoense & 1 \\
& Operculum & 1 \\
Egg Cases & Egg cases & 5 \\
Pollen & Pollen & 88 \\
Prasinophycean Algae & Pterospermella & 3 \\
& Cymatiosphaera sp. 2 & 2 \\
Red Algae & Beringiella sp. & 12 \\
Zooplankton & Tintinnid loricae & 3 \\
& Zooplankton sp. & 8 \\
Foraminiferan linings & & 17 \\
Insect parts & & 6 \\
& &
\end{tabular}

\begin{tabular}{|c|c|c|c|c|}
\hline Sample & 901-20 & & & \\
\hline Lithology & $\begin{array}{ll}\text { gravel } & 30.46 \\
\text { sand } & 42.18 \\
\text { silt } & 13.4 \\
\text { clay } & 13.96 \\
\text { Total Count }\end{array}$ & 113 & $\begin{array}{l}\text { Bathymetry } \\
\text { Latitude } \\
\text { Longitude }\end{array}$ & $\begin{array}{l}318 \mathrm{~m} \\
-67.23583 \\
76.55516\end{array}$ \\
\hline$\underline{\text { Pal }}$ & omorphs & Count & & \\
\hline Acritarchs & & Leiospherida $\mathrm{sp}$ & & 1 \\
\hline Dinoflagell & & Impagidinium $\mathrm{s}$ & & 1 \\
\hline Egg Cases & & Egg cases & & 2 \\
\hline Pollen & & Pollen & & 70 \\
\hline Prasinophy & Algae & Cymatiosphaer & ra sp. 2 & 1 \\
\hline Red Algae & & Beringiella sp. & & 4 \\
\hline Zooplankto & & $\begin{array}{l}\text { Tintinnid lorica } \\
\text { Zooplankton } \mathrm{sp}\end{array}$ & & $\begin{array}{l}4 \\
20\end{array}$ \\
\hline Foraminife & linings & & & 9 \\
\hline Insect parts & & & & 1 \\
\hline & & & Total Count & 113 \\
\hline
\end{tabular}




\begin{tabular}{lclll}
\hline Sample & $\mathbf{9 0 1 - 2 2}$ & & \\
\hline Lithology & gravel & 0 & Bathymetry & $766 \mathrm{~m}$ \\
& sand 7.39 & Latitude & -68.065 \\
& silt & 23.15 & Longitude & 72.276 \\
& clay & 69.46 & & \\
& & & &
\end{tabular}

\begin{tabular}{lll}
\multicolumn{1}{c}{ Palynomorphs } & Count & \\
Unknowns & Unknown sp. 6 & 2 \\
Acritarchs & Leiospherida spp. & 2 \\
& Sphaeoromorphs & 4 \\
Dinoflagellates & Dinocyst sp. & 1 \\
Egg Cases & Egg cases & 16 \\
Pollen & Pollen & 16 \\
Prasinophycean Algae & Cymatiosphaera sp. 2 & 14 \\
Red Algae & Beringiella sp. & 26 \\
Zooplankton & Tintinnid loricae & 9 \\
& Zooplankton spp. & 326 \\
Foraminiferan linings & Tintinnid cyst & 3 \\
Insect parts & & 72 \\
& & 51 \\
& &
\end{tabular}




\begin{tabular}{llll}
\hline Sample & $\mathbf{9 0 1 - 2 3}$ & & \\
\hline Lithology & gravel 0 & Bathymetry & $661 \mathrm{~m}$ \\
& sand 7.96 & Latitude & -68.08183 \\
& silt 25.66 & Longitude & 72.984 \\
& clay 66.37 & & \\
& Total Count 856 & & \\
&
\end{tabular}

\section{Palynomorphs Count}

$\begin{array}{lll}\text { Unknowns } & \text { Unknown sp. 3 } & 2 \\ & \text { Unknown sp. 6 } & 2 \\ \text { Acritarchs } & \text { Leiospherida sp. } & 5 \\ & \text { Acritarch sp. 4 } & 1 \\ & \text { Sphaeoromorphs } & 59 \\ \text { Dinoflagellates } & \text { Selenopemphix antarctica } & 7 \\ & \text { Cryodinium sp. } & 2 \\ \text { Egg Cases } & \text { Protoperidinium sp. 2 } & 6 \\ \text { Pollen } & \text { Egg cases } & 54 \\ \text { Prasinophycean Algae } & \text { Pollen } & 2 \\ & \text { Cymatiosphaera sp. 2 } & 17 \\ \text { Red Algae } & \text { Pterospermella } & 3 \\ \text { Zooplankton } & \text { Beringiella sp. } & 28 \\ & \text { Tintinnid loricae } & 31 \\ \text { Foraminiferan linings } & \text { Tintinnid cyst } & 3 \\ \text { Insect parts } & \text { Zooplankton spp. } & 300 \\ & & 251 \\ & & 83 \\ & & \text { Total Count } \\ & & \end{array}$




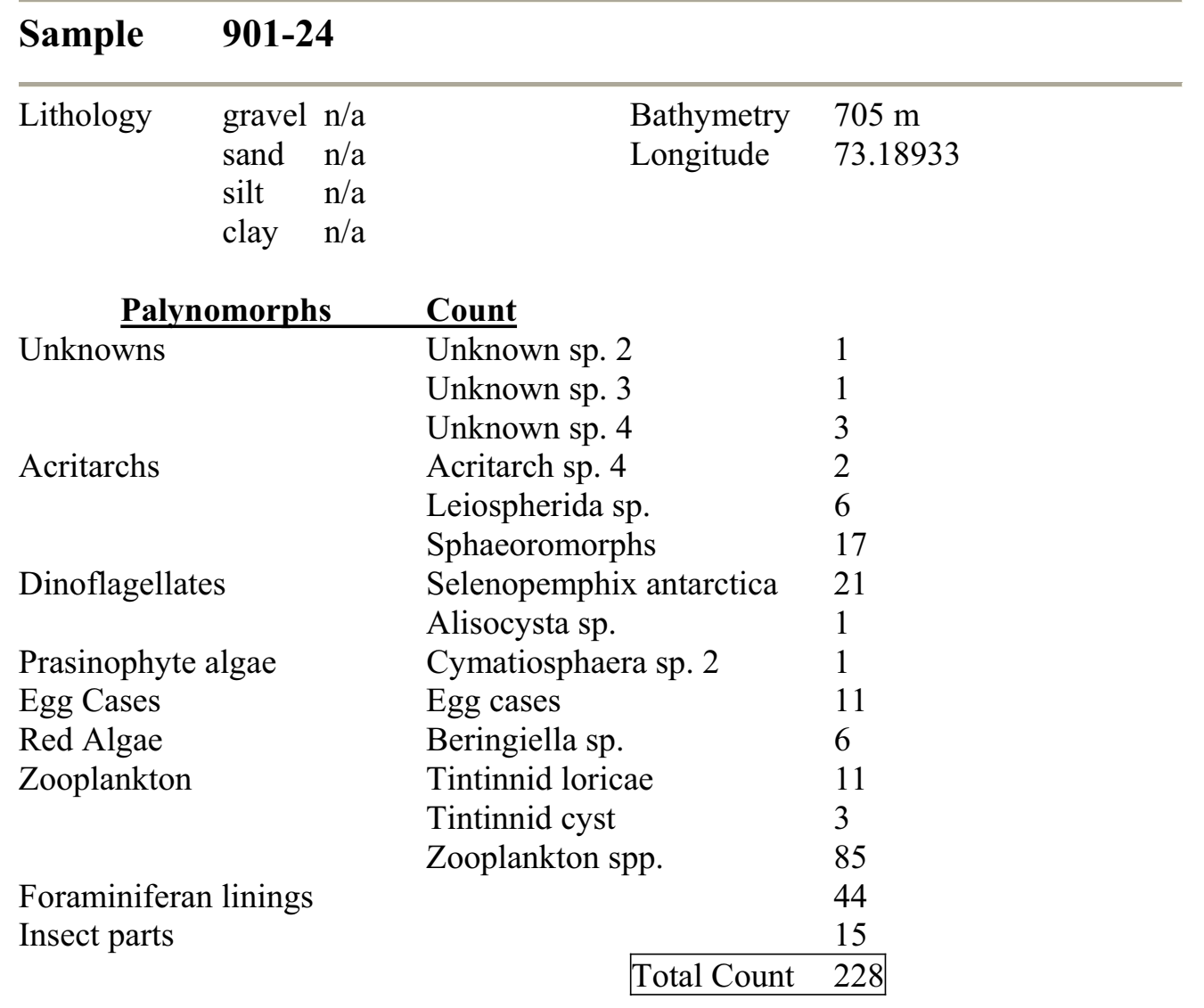




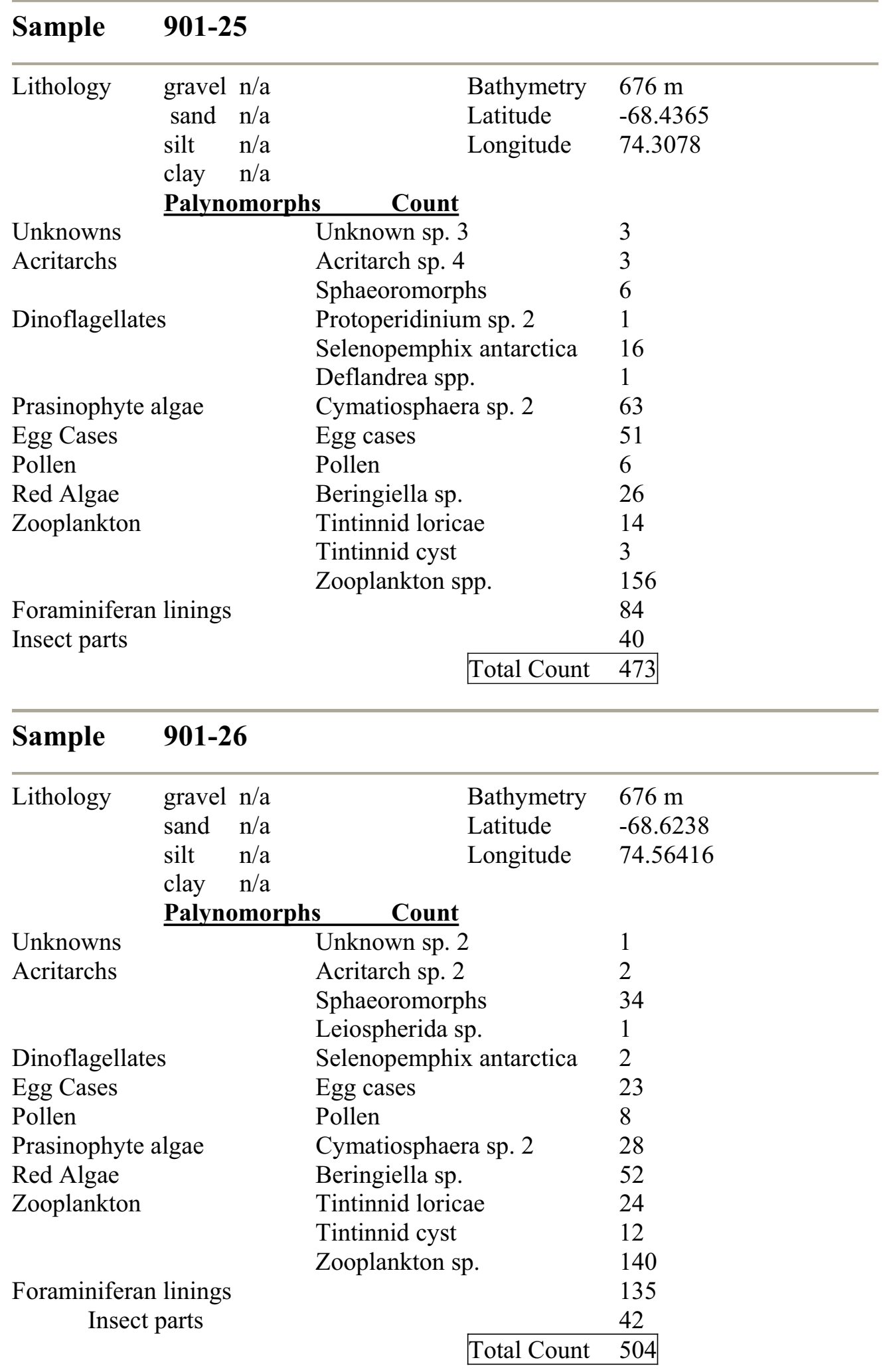




\begin{tabular}{|c|c|c|c|c|}
\hline Sample & 901-27 & & & \\
\hline Lithology & $\begin{array}{cl}\text { gravel } & 1.75 \\
\text { sand } & 10.53 \\
\text { silt } & 28.51 \\
\text { clay } & 59.21\end{array}$ & & $\begin{array}{l}\text { Bathymetry } \\
\text { Latitude } \\
\text { Longitude }\end{array}$ & $\begin{array}{l}776 \mathrm{~m} \\
-68.9465 \\
73.58566\end{array}$ \\
\hline Pal & omorphs & Count & & \\
\hline Unknowns & & $\begin{array}{l}\text { Unknown sp. } 1 \\
\text { Unknown sp. } 6\end{array}$ & & $\begin{array}{l}1 \\
4\end{array}$ \\
\hline Acritarchs & & Sphaeoromorph & & 15 \\
\hline Dinoflagell & & Turbiosphaera f & filosa & 1 \\
\hline Prasinophy & algae & Cymatiosphaera & a sp. 2 & 40 \\
\hline Egg Cases & & Egg cases & & 8 \\
\hline Pollen & & Pollen & & 12 \\
\hline Red Algae & & Beringiella sp. & & 15 \\
\hline Zooplankto & & Tintinnid lorica & & 3 \\
\hline & & Tintinnid cyst & & 6 \\
\hline & & Zooplankton sp & & 89 \\
\hline Foraminife & linings & & & 75 \\
\hline Insect parts & & & & 28 \\
\hline & & & Total Count & 297 \\
\hline
\end{tabular}

\begin{tabular}{|c|c|c|c|}
\hline Sample & 901-28 & & \\
\hline Lithology & $\begin{array}{ll}\text { gravel } & 0 \\
\text { sand } & 64.44 \\
\text { silt } & 18.13 \\
\text { clay } & 17.43\end{array}$ & $\begin{array}{l}\text { Bathymetry } \\
\text { Latitude } \\
\text { Longitude }\end{array}$ & $\begin{array}{l}710 \mathrm{~m} \\
-68.91533 \\
76.58933\end{array}$ \\
\hline
\end{tabular}

\begin{tabular}{lll}
\multicolumn{1}{c}{ Palynomorphs } & Count & \\
Unknowns & Unknown sp. 6 & 2 \\
& Unknown sp. 7 & 2 \\
& Unknown sp. 8 & 1 \\
& Unknown sp. 9 & 1 \\
Acritarchs & Sphaeoromorphs & 1 \\
Dinoflagellates & Protoperidinium sp. 2 & 1 \\
Prasinophyte algae & Cymatiosphaera sp. 2 & 8 \\
Egg Cases & Egg cases & 11 \\
Pollen & Pollen & 1 \\
Red Algae & Beringiella sp. & 28 \\
Zooplankton & Tintinnid loricae & 2 \\
& Zooplankton sp. & 92 \\
Foraminiferan linings & & 178 \\
Insect parts & & 23 \\
& &
\end{tabular}




\begin{tabular}{|c|c|c|c|c|}
\hline Sample & 901-31 & & & \\
\hline Lithology & $\begin{array}{ll}\text { gravel } & 0 \\
\text { sand } & 17.88 \\
\text { silt } & 38.41 \\
\text { clay } & 43.71\end{array}$ & & $\begin{array}{l}\text { Bathymetry } \\
\text { Latitude } \\
\text { Longitude }\end{array}$ & $\begin{array}{l}806 \mathrm{~m} \\
-68.68183 \\
76.8765\end{array}$ \\
\hline \multicolumn{2}{|c|}{ Palynomorphs } & \multicolumn{2}{|l|}{ Count } & \\
\hline \multicolumn{2}{|c|}{ Unknowns } & $\begin{array}{l}\text { Unknown sp. } 4 \\
\text { Unknown sp. } 6 \\
\text { Unknown sp. } 7\end{array}$ & & $\begin{array}{l}2 \\
10 \\
1\end{array}$ \\
\hline \multicolumn{2}{|l|}{ Acritarchs } & \multicolumn{2}{|l|}{ Sphaeoromorphs } & 4 \\
\hline \multicolumn{2}{|l|}{ Egg Cases } & \multicolumn{2}{|l|}{ Egg cases } & 6 \\
\hline \multicolumn{2}{|l|}{ Pollen } & \multicolumn{2}{|l|}{ Pollen } & 17 \\
\hline \multicolumn{2}{|l|}{ Red Algae } & \multicolumn{2}{|l|}{ Beringiella sp. } & 22 \\
\hline \multirow{3}{*}{\multicolumn{2}{|c|}{ Zooplankton }} & \multicolumn{2}{|l|}{ Tintinnid loricae } & 6 \\
\hline & & \multicolumn{2}{|l|}{ Tintinnid cyst } & 3 \\
\hline & & \multicolumn{2}{|l|}{ Zooplankton sp. } & 173 \\
\hline \multirow{2}{*}{\multicolumn{2}{|c|}{$\begin{array}{l}\text { Foraminiferan linings } \\
\text { Insect parts }\end{array}$}} & & & 155 \\
\hline & & & & 34 \\
\hline & & Total Count & 433 \\
\hline
\end{tabular}

\section{Sample 901-33}

\begin{tabular}{lllll}
\hline Lithology & gravel & 0 & Bathymetry & 376 \\
& sand & 62.15 & Latitude & -67.18133 \\
& silt & 27.57 & Longitude & 68.53833 \\
& clay & 10.28 & &
\end{tabular}

\begin{tabular}{lll}
\multicolumn{1}{c}{ Palynomorphs } & Count & \\
Unknowns & Unknown sp. 1 & 2 \\
& Unknown sp. 3 & 2 \\
& Unknown sp. 6 & 2 \\
& Unknown sp. 4 & 1 \\
& Unknown sp. 7 & 1 \\
Acritarchs & Leiospherida sp. & 1 \\
& Sphaeoromorphs & 37 \\
Dinoflagellates & Protoperidinium sp. 2 & 3 \\
Egg Cases & Egg cases & 29 \\
Pollen & Pollen & 2 \\
Prasinophycean Algae & Pterospermella & 1 \\
& Cymatiosphaera sp. 2 & 2 \\
Red Algae & Beringiella sp. & 4 \\
Zooplankton & Tintinnid loricae & 3 \\
& Zooplankton sp. & 232 \\
Foraminiferan linings & & 344 \\
Insect parts & & 18 \\
& & 684
\end{tabular}




\section{Sample 901-34 Kergulen Plateau not Prydz Bay error}

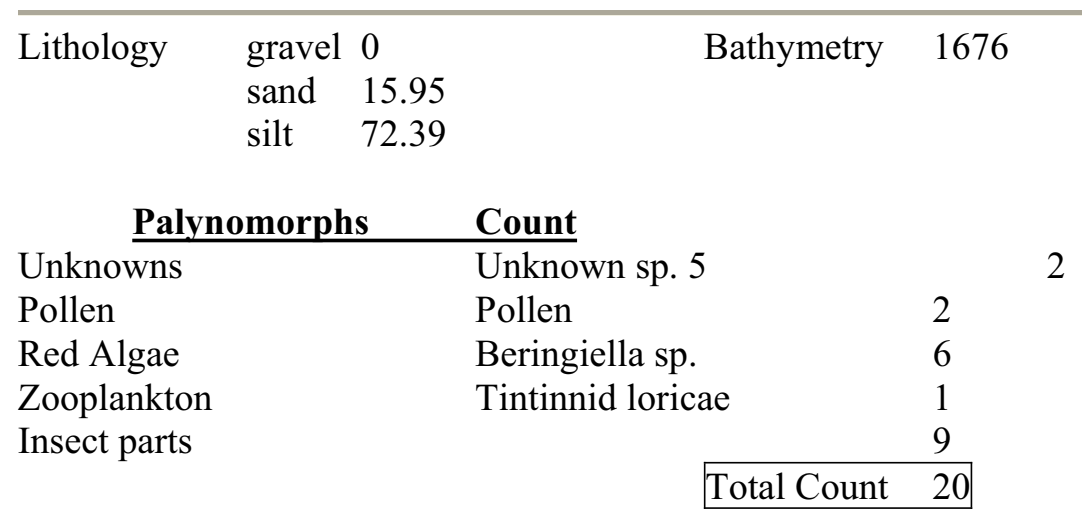

\begin{tabular}{|c|c|c|c|}
\hline Sample & $149-6$ & & \\
\hline Lithology & $\begin{array}{ll}\text { gravel } & 2.77 \\
\text { sand } & 55.86 \\
\text { silt } & 19.97 \\
\text { clay } & 21.4\end{array}$ & $\begin{array}{l}\text { Bathymetry } \\
\text { Latitude } \\
\text { Longitude }\end{array}$ & $\begin{array}{l}805 \mathrm{~m} \\
-66.931667 \\
64.938333\end{array}$ \\
\hline
\end{tabular}

\begin{tabular}{|c|c|c|}
\hline \multicolumn{3}{|c|}{ Palynomorphs } \\
\hline Pollen & Pollen & 382 \\
\hline \multirow[t]{2}{*}{ Prasinophycean Algae } & Cymatiosphaera sp. 1 & 3 \\
\hline & Pterospermella & 1 \\
\hline \multirow[t]{3}{*}{ Zooplankton } & Tintinnid loricae & 1 \\
\hline & Zooplankton sp. & 2 \\
\hline & Total Count & 389 \\
\hline
\end{tabular}

\section{Sample 149-14}

\begin{tabular}{llcll}
\hline Lithology & gravel & 3.5 & Bathymetry & $849 \mathrm{~m}$ \\
& sand & 57.97 & Latitude & -66.64 \\
& silt & 14.58 & Longitude & 71.7333333 \\
& clay & 23.96 & & \\
& & & &
\end{tabular}

\section{Palynomorphs Count}

\begin{tabular}{lll} 
Pollen & Pollen & 54 \\
\cline { 2 - 2 } & Total Count & 54
\end{tabular}




\section{Sample 149-15}

\begin{tabular}{llrll}
\hline Lithology & gravel & 6.71 & Bathymetry & $2250 \mathrm{~m}$ \\
& sand & 39.76 & Latitude & -66.253333 \\
& silt & 17.15 & Longitude & 73.34 \\
& clay & 36.38 & & \\
& & & &
\end{tabular}

Palynomorphs Count

$\begin{array}{lll}\text { Dinoflagellates } & \text { Turbiosphaera filosa } & 2 \\ \text { Pollen } & \text { Pollen } & 31 \\ & & \end{array}$

\begin{tabular}{|c|c|c|c|}
\hline Sample & 149-16 & & \\
\hline Lithology & $\begin{array}{ll}\text { gravel } & 0.5 \\
\text { sand } & 7.25 \\
\text { silt } & 45.25 \\
\text { clay } & 47\end{array}$ & $\begin{array}{l}\text { Bathymetry } \\
\text { Latitude } \\
\text { Longitude }\end{array}$ & $\begin{array}{l}1960 \mathrm{~m} \\
-66.385 \\
73.185\end{array}$ \\
\hline
\end{tabular}

\begin{tabular}{|c|c|c|}
\hline \multirow{3}{*}{$\begin{array}{l}\text { Palynomorphs } \\
\text { Pollen } \\
\text { Insect parts }\end{array}$} & \multirow{2}{*}{$\frac{\text { Count }}{\text { Pollen }}$} & \\
\hline & & 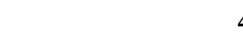 \\
\hline & & \\
\hline
\end{tabular}

\begin{tabular}{|c|c|c|c|}
\hline Sample & 149-17 & & \\
\hline Lithology & $\begin{array}{ll}\text { gravel } & 0.67 \\
\text { sand } & 10.72 \\
\text { silt } & 26.01 \\
\text { clay } & 62.6\end{array}$ & $\begin{array}{l}\text { Bathymetry } \\
\text { Latitude } \\
\text { Longitude }\end{array}$ & $\begin{array}{l}1540 \mathrm{~m} \\
-66.503333 \\
73.091667\end{array}$ \\
\hline
\end{tabular}

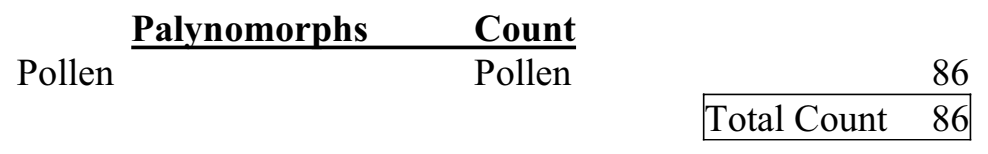




\section{Sample 149-18}

\begin{tabular}{lllll}
\hline Lithology & gravel & 12.61 & Bathymetry & 1174 \\
& sand & 37.31 & Latitude & -66.6 \\
& silt & 17.69 & Longitude & 73.008333 \\
& clay & 32.39 & & \\
& & & &
\end{tabular}

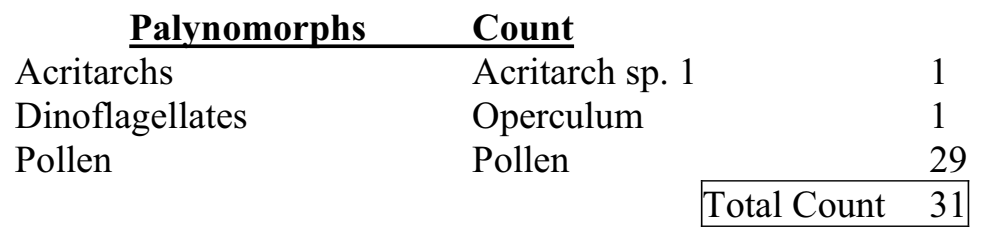

\begin{tabular}{llll}
\hline Sample & $\mathbf{1 4 9 - 1 9}$ & & \\
\hline Lithology & gravel 10.3 & Bathymetry & 765 \\
& sand 71.57 & Latitude & -66.686667 \\
& silt 9.42 & Longitude & 72.925 \\
& clay 8.71 & & \\
& & &
\end{tabular}

\begin{tabular}{|c|c|}
\hline Palynomorphs & Count \\
\hline Pollen & $\overline{\text { Pollen }}$ \\
\hline Dinoflagellates & Alterbidinium asymmetrica \\
\hline & Operculum \\
\hline \multirow{3}{*}{ Acritarch } & Vozzhennikovia sp. \\
\hline & Sigmopollis \\
\hline & Total Count \\
\hline
\end{tabular}

\section{Sample 149-21}

\begin{tabular}{lllll}
\hline Lithology & gravel & 2.86 & Bathymetry & 1060 \\
& sand & 57.92 & Latitude & -66.618333 \\
& silt & 17.05 & Longitude & 72.293333 \\
& clay & 22.16 & & \\
& & & &
\end{tabular}

Total Count 211

\begin{tabular}{|c|c|c|}
\hline \multirow{5}{*}{$\begin{array}{l}\text { Palynomorphs } \\
\text { Pollen } \\
\text { Zooplankton } \\
\text { Foraminiferan linings }\end{array}$} & Count & \\
\hline & Pollen & 208 \\
\hline & Zooplankton sp. & 2 \\
\hline & & 1 \\
\hline & Total Count & 211 \\
\hline
\end{tabular}




\begin{tabular}{lllll}
\hline Sample & $\mathbf{1 4 9 - 2 2}$ & & \\
\hline Lithology & gravel & 0.53 & Bathymetry & $1450 \mathrm{~m}$ \\
& sand & 46.34 & Latitude & -66.456667 \\
& silt & 23.32 & Longitude & 72.29667 \\
& clay & 29.82 & & \\
& & & &
\end{tabular}

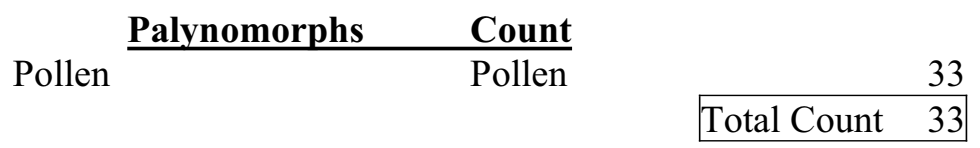

\begin{tabular}{lllll}
\hline Sample & $\mathbf{1 4 9 - 2 3}$ & & \\
\hline Lithology & gravel & 2.34 & Bathymetry & $1884 \mathrm{~m}$ \\
& sand & 30.43 & Latitude & -66.32 \\
& silt & 20.48 & Longitude & 72.293333 \\
& clay & 46.74 & & \\
& & & &
\end{tabular}

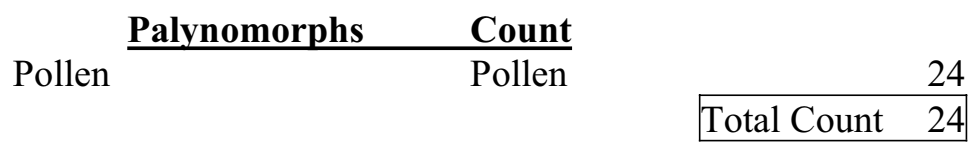

\begin{tabular}{lllll}
\hline Sample & $\mathbf{1 4 9 - 2 4}$ & & \\
\hline Lithology & gravel & 0 & Bathymetry & $2535 \mathrm{~m}$ \\
& sand & 4.58 & Latitude & -66.011667 \\
& silt 17.81 & Longitude & 71.535 \\
& clay & 77.61 & & \\
& & & &
\end{tabular}

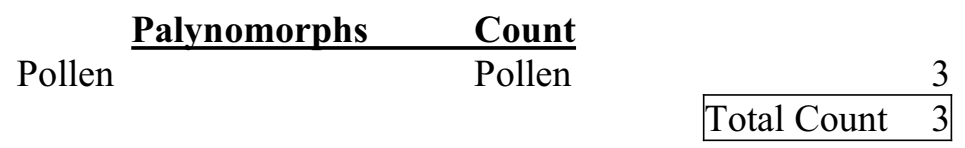

\begin{tabular}{lllll}
\hline Sample & $\mathbf{1 4 9 - 2 5}$ & & \\
\hline Lithology & gravel & 0 & Bathymetry & $2010 \mathrm{~m}$ \\
& sand & 10.22 & Latitude & -66.3 \\
& silt & 29.28 & Longitude & 71.601666 \\
& clay & 60.5 & & \\
& & & &
\end{tabular}

\section{$\underline{\text { Palynomorphs } \quad \text { Count }}$}

Total Count 0 


\begin{tabular}{llll}
\hline Sample & $\mathbf{1 4 9 - 2 7}$ & & \\
\hline Lithology & gravel 1.79 & Bathymetry & $1200 \mathrm{~m}$ \\
& sand 60.18 & Latitude & -66.568333 \\
& silt 14.77 & Longitude & 71.713333 \\
& clay 23.27 & & \\
& & & \\
& Total Count & 399 &
\end{tabular}

Palynomorphs Count

Dinoflagellates $\quad$ Alterbidinium asymmetrica 1

$\begin{array}{lll}\text { Pollen } & \text { Pollen } & 397\end{array}$

Acritarach

Leiospherida sp. $\quad 1$

Total Count 399

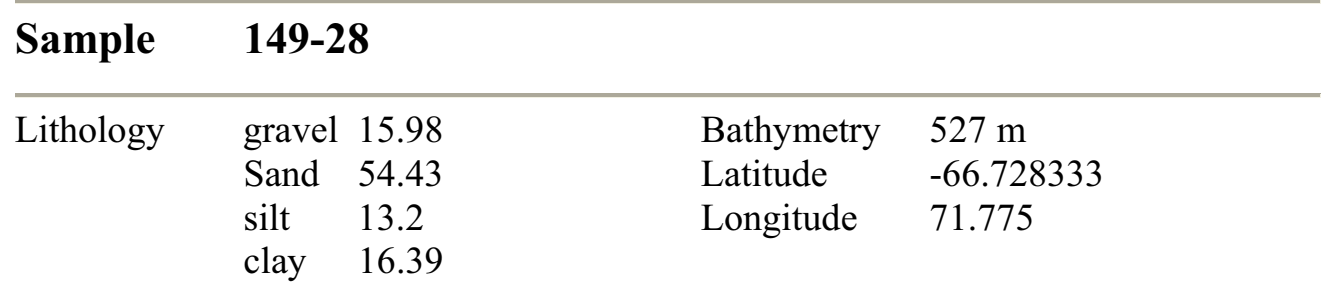

\section{Palynomorphs Count}

$\begin{array}{lll}\text { Unknowns } & \text { Unknown sp. 6 } & 1 \\ \text { Acritarchs } & \text { Sphaeoromorphs } & 2 \\ \text { Dinoflagellates } & \text { Operculum } & 1 \\ & \text { Hystrichosphaeridium spp. } & 3 \\ & \text { Spinodinium spp. } & 1 \\ & \text { Vozzhennikovia spp. } & 3 \\ \text { Egg Cases } & \text { Egg cases } & 1 \\ \text { Pollen } & \text { Pollen } & 107 \\ \text { Red Algae } & \text { Beringiella sp. } & 1 \\ \text { Zooplankton } & \text { Tintinnid loricae } & 1 \\ & \text { Zooplankton sp. } & 8 \\ \text { Foraminiferan linings } & & 8 \\ \text { Insect parts } & & 3 \\ & & \text { Total Count } \\ \end{array}$




\begin{tabular}{lllll}
\hline Sample & $\mathbf{1 4 9 - 3 0}$ & & \\
\hline Lithology & gravel & 5.57 & Bathymetry & $515 \mathrm{~m}$ \\
& sand & 62.46 & Latitude & -66.783333 \\
& silt & 17.01 & Longitude & 71.791667 \\
& clay 14.96 & & \\
\hline
\end{tabular}

\begin{tabular}{lll}
\multicolumn{1}{c}{ Palynomorphs } & Count & \\
Unknowns & Unknown sp. 6 & 2 \\
& Unknown sp. 7 & 1 \\
Dinoflagellates & Alterbidinium asymmetrica & 1 \\
& Operculum & 2 \\
& Vozzhennikovia spp & 1 \\
Egg Cases & Egg cases & 2 \\
Prasinophyte algae & Cymatiosphaera sp. 2 & 1 \\
Acritarchs & Sphaeoromorphs & 2 \\
Pollen & Pollen & 40 \\
Zooplankton & Tintinnid loricae & 3 \\
& Zooplankton sp. & 9 \\
Foraminiferan linings & & 19 \\
Insect parts & & 15 \\
& &
\end{tabular}

\section{Sample 149-31}

\begin{tabular}{lllll}
\hline Lithology & gravel & 0.8 & Bathymetry & $512 \mathrm{~m}$ \\
& sand & 61.23 & Latitude & -66.838333 \\
& silt & 15.51 & Longitude & 71.816667 \\
& clay & 22.46 & & \\
& & & &
\end{tabular}

\begin{tabular}{lll}
\multicolumn{1}{c}{ Palynomorphs } & Count & \\
Unknowns & Unknown sp. 6 & 1 \\
Egg Cases & Egg cases & 1 \\
Pollen & Pollen & 10 \\
Prasinophycean Algae & Pterospermella & 1 \\
& Tasmanites & 1 \\
Red Algae & Beringiella sp. & 7 \\
Zooplankton & Tintinnid loricae & 1 \\
& Zooplankton sp. & 20 \\
Foraminiferan linings & & 19 \\
Insect parts & & 3 \\
& & Total Count
\end{tabular}




\begin{tabular}{|c|c|c|c|}
\hline Sample & 149-32 & & \\
\hline Lithology & $\begin{array}{ll}\text { gravel } & 3 \\
\text { sand } & 57.92 \\
\text { silt } & 19.69 \\
\text { clay } & 19.4\end{array}$ & $\begin{array}{l}\text { Bathymetry } \\
\text { Latitude } \\
\text { Longitude }\end{array}$ & $\begin{array}{l}502 \mathrm{~m} \\
-66.926667 \\
71.846667\end{array}$ \\
\hline
\end{tabular}

\begin{tabular}{lll}
\multicolumn{1}{c}{ Palynomorphs } & Count & \\
Acritarchs & Sphaeoromorphs & 4 \\
Dinoflagellates & Turbiosphaera filosa & 1 \\
& Enneadocysta partridgei & 1 \\
& Operculum & 1 \\
& Hystrichosphaeridium sp. & 1 \\
& Vozzhennikovia sp. & 4 \\
Egg Cases & Egg cases & 3 \\
Pollen & Pollen & 96 \\
Prasinophycean Algae & Cymatiosphaera sp. 1 & 1 \\
Red Algae & Beringiella sp. & 4 \\
Zooplankton & Tintinnid loricae & 3 \\
& Zooplankton sp. & 34 \\
Foraminiferan linings & & 29 \\
Insect parts & & 13 \\
& & Total Count \\
\end{tabular}

\begin{tabular}{|c|c|c|c|}
\hline Sample & 149-33 & & \\
\hline Lithology & $\begin{array}{ll}\text { gravel } & 9.64 \\
\text { sand } & 25.12 \\
\text { silt } & 31.2 \\
\text { clay } & 34.04\end{array}$ & $\begin{array}{l}\text { Bathymetry } \\
\text { Latitude } \\
\text { Longitude }\end{array}$ & $\begin{array}{l}834 \mathrm{~m} \\
-66.715 \\
71.365\end{array}$ \\
\hline
\end{tabular}

\begin{tabular}{llll}
\multicolumn{1}{l}{ Palynomorphs } & Count & & \\
\cline { 2 - 4 } Pollen & Pollen & & 183 \\
Acritarch & Sigmopollis & & 1 \\
\cline { 3 - 4 } & & Total Count & 184 \\
\cline { 3 - 4 } & &
\end{tabular}

\begin{tabular}{|c|c|c|c|}
\hline Sample & 149-34 & & \\
\hline \multirow[t]{4}{*}{ Lithology } & gravel 8.47 & Bathymetry & $1215 \mathrm{~m}$ \\
\hline & sand 81.8 & Latitude & -66.665 \\
\hline & 5.99 & Longitude & 71.206667 \\
\hline & clay $\quad 3.74$ & & \\
\hline
\end{tabular}

\begin{tabular}{|c|c|c|c|c|}
\hline & Palynomorphs & Count & & \\
\hline Pollen & & Pollen & & 45 \\
\hline & & & Total Count & 45 \\
\hline
\end{tabular}




\begin{tabular}{|c|c|c|c|}
\hline Sample & 149-35 & & \\
\hline Lithology & $\begin{array}{ll}\text { gravel } & 0.54 \\
\text { sand } & 49.82 \\
\text { silt } & 29.86 \\
\text { clay } & 19.78\end{array}$ & $\begin{array}{l}\text { Bathymetry } \\
\text { Latitude } \\
\text { Longitude }\end{array}$ & $\begin{array}{l}1566 \mathrm{~m} \\
-66.586666 \\
71.01\end{array}$ \\
\hline
\end{tabular}

\section{Palynomorphs Count}

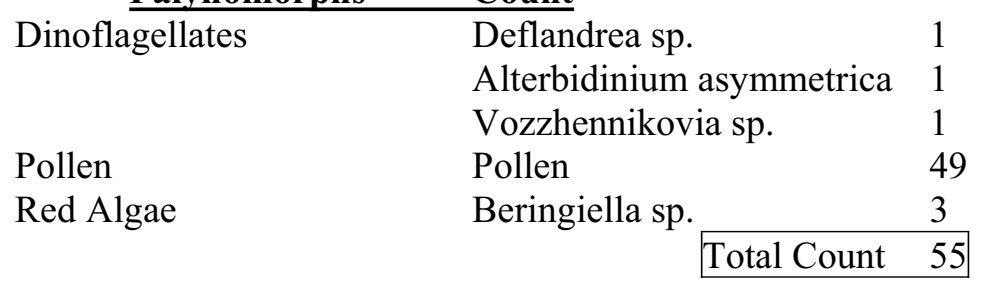

\begin{tabular}{|c|c|c|c|}
\hline Sample & 149-36 & & \\
\hline Lithology & $\begin{array}{ll}\text { gravel } & 1.44 \\
\text { sand } & 12.61 \\
\text { silt } & 7.39 \\
\text { clay } & 78.56\end{array}$ & $\begin{array}{l}\text { Bathymetry } \\
\text { Latitude } \\
\text { Longitude }\end{array}$ & $\begin{array}{l}2105 \mathrm{~m} \\
-66.45 \\
70.575\end{array}$ \\
\hline
\end{tabular}

\section{Palynomorphs Count}

Dinoflagellates

Operculum 3

Spinodinium macmurdoense 1

Pollen

Zooplankton

Pollen 15

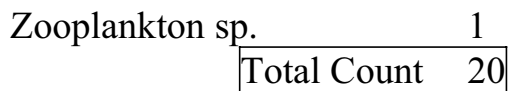




\begin{tabular}{|c|c|c|c|c|}
\hline Sample & 149-37 & & & \\
\hline Lithology & $\begin{array}{ll}\text { gravel } & 1.4 \\
\text { sand } & 89.94 \\
\text { silt } & 5.87 \\
\text { clay } & 2.79 \\
\text { Total } & \text { Count }\end{array}$ & 213 & $\begin{array}{l}\text { Bathymetry } \\
\text { Latitude } \\
\text { Longitude }\end{array}$ & $\begin{array}{l}168 \mathrm{~m} \\
-67.08 \\
66.701667\end{array}$ \\
\hline \multicolumn{2}{|c|}{ Palynomorphs } & \multicolumn{3}{|l|}{ Count } \\
\hline \multicolumn{2}{|c|}{ Unknowns } & \multicolumn{2}{|l|}{ Unknown sp. 1} & 1 \\
\hline \multicolumn{2}{|c|}{ Prasinophyte algae } & \multicolumn{2}{|c|}{ Cymatiosphaera sp. 2} & 6 \\
\hline \multicolumn{2}{|c|}{ Egg Cases } & \multicolumn{2}{|c|}{ Egg cases } & 10 \\
\hline \multicolumn{2}{|l|}{ Pollen } & \multicolumn{2}{|l|}{ Pollen } & 2 \\
\hline \multicolumn{2}{|c|}{ Red Algae } & \multicolumn{2}{|l|}{ Beringiella sp. } & 20 \\
\hline \multicolumn{2}{|c|}{ Zooplankton } & \multicolumn{2}{|l|}{$\begin{array}{l}\text { Tintinnid loricae } \\
\text { Zooplankton sp. }\end{array}$} & $\begin{array}{l}4 \\
39\end{array}$ \\
\hline \multicolumn{4}{|c|}{ Foraminiferan linings } & 124 \\
\hline \multicolumn{2}{|c|}{ Insect parts } & & & 7 \\
\hline & & & Total Count & 213 \\
\hline
\end{tabular}

\begin{tabular}{|c|c|c|c|}
\hline Sample & $186-9$ & & \\
\hline Lithology & $\begin{array}{ll}\text { gravel } & 1.43 \\
\text { sand } & 42.75 \\
\text { silt } & 13.34 \\
\text { clay } & 42.47\end{array}$ & $\begin{array}{l}\text { Bathymetry } \\
\text { Latitude } \\
\text { Longitude }\end{array}$ & $\begin{array}{l}698 \mathrm{~m} \\
-68.066667 \\
72.9\end{array}$ \\
\hline
\end{tabular}

\section{Palynomorphs}

\section{Count}

Unknowns

Unknown sp. 5

2

Acritarchs

Acritarch sp. 4

Sphaeoromorphs

Prasinophyte algae

Cymatiosphaera sp. 2

1

Egg Cases

Egg cases

6

Pollen

Pollen

14

Red Algae

Beringiella sp.

Zooplankton

Tintinnid loricae

Zooplankton sp.

Foraminiferan linings

Insect parts

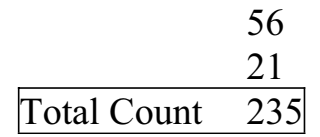




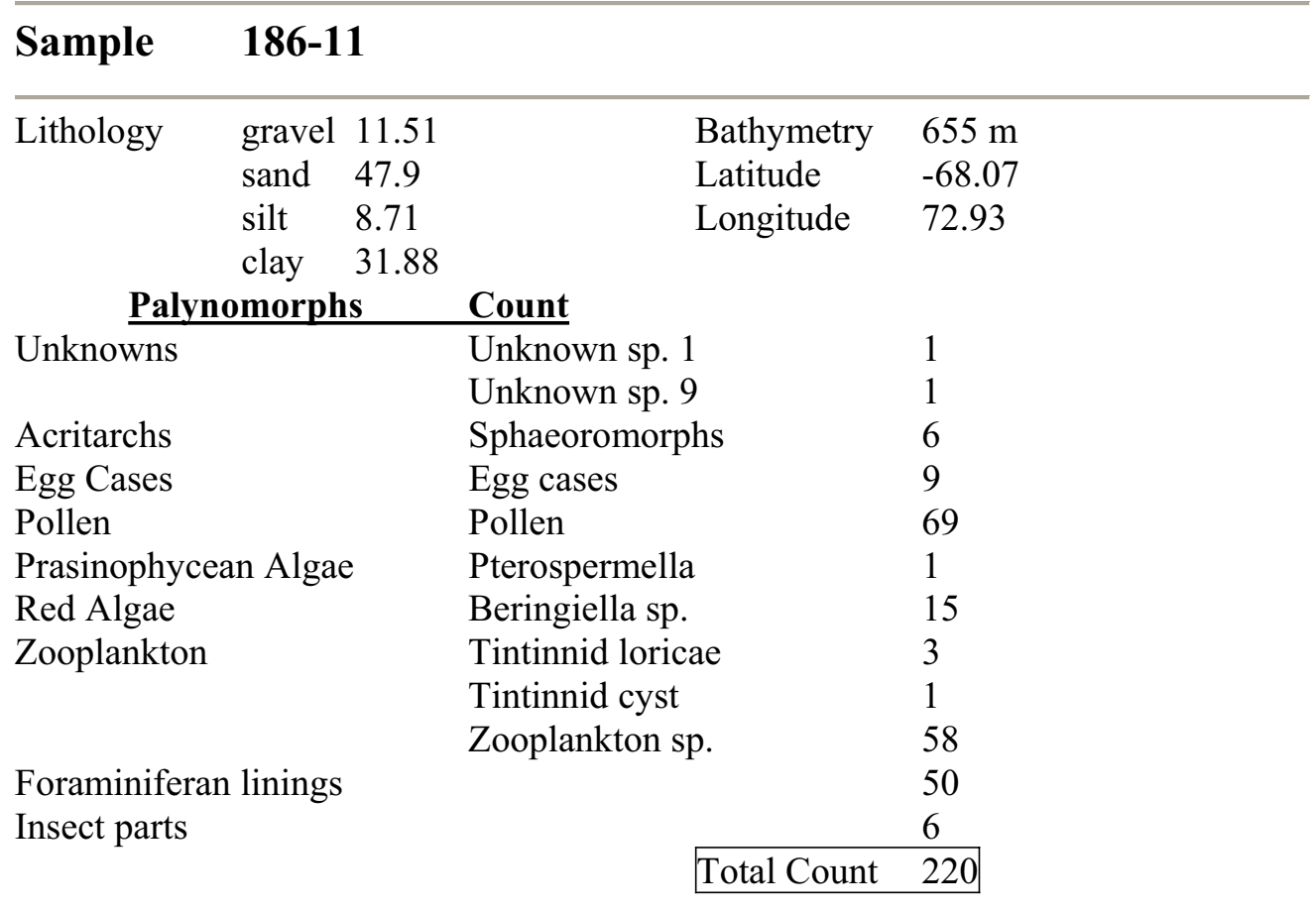

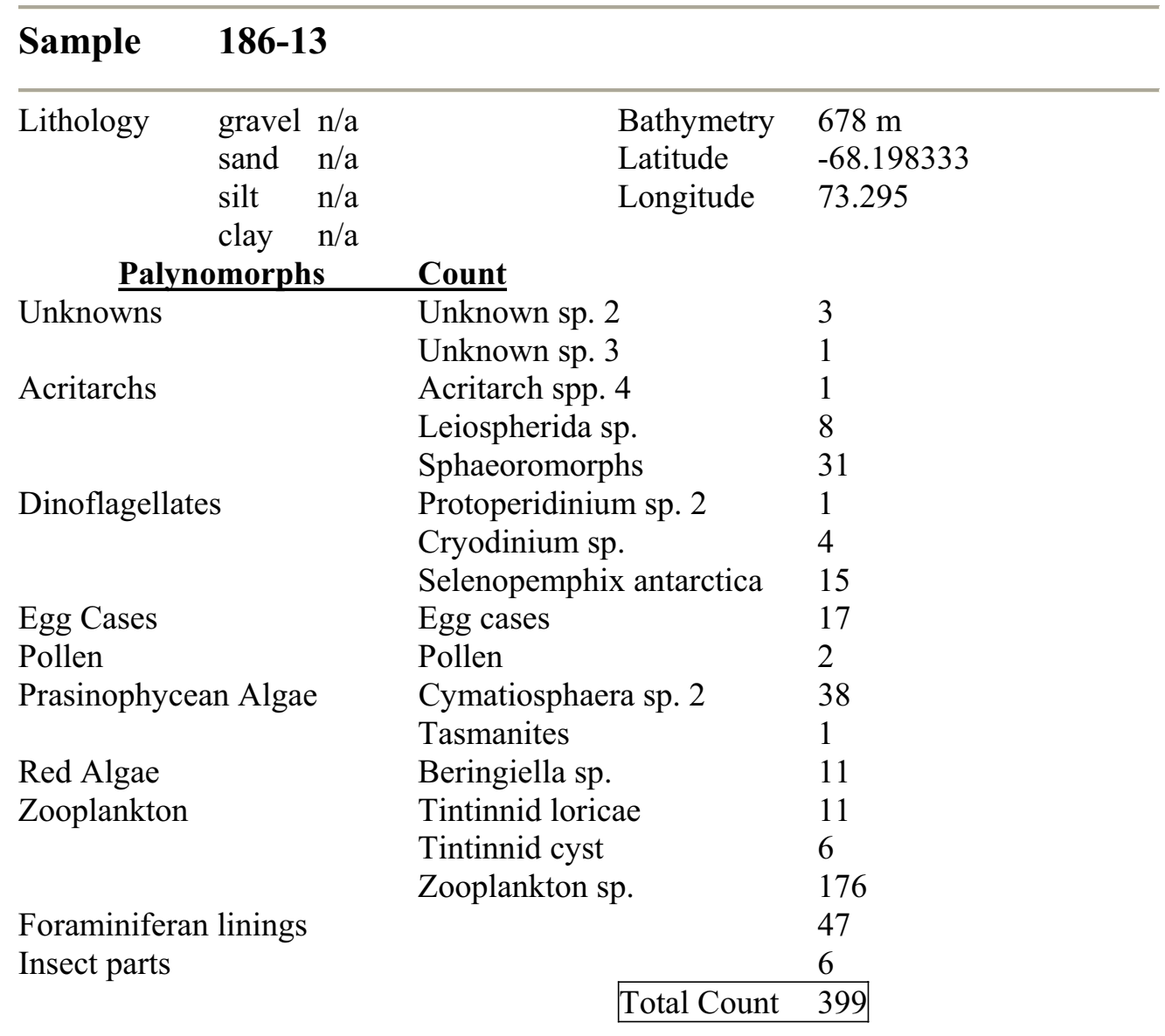




\begin{tabular}{|c|c|c|c|}
\hline Sample & $186-14$ & & \\
\hline Lithology & $\begin{array}{ll}\text { gravel } & 8.61 \\
\text { sand } & 19.21 \\
\text { silt } & 17.88 \\
\text { clay } & 54.3\end{array}$ & $\begin{array}{l}\text { Bathymetry } \\
\text { Latitude } \\
\text { Longitude }\end{array}$ & $\begin{array}{l}690 \mathrm{~m} \\
-68.22 \\
73.383333\end{array}$ \\
\hline
\end{tabular}

\begin{tabular}{lll} 
& Palynomorphs & \multicolumn{1}{c}{ Count } \\
Unknowns & Unknown sp. 3 & 1 \\
& Unknown sp. 6 & 2 \\
Acritarchs & Sphaeoromorphs & 5 \\
Dinoflagellates & Protoperidinium sp. 2 & 1 \\
Egg Cases & Egg cases & 14 \\
Pollen & Pollen & 1 \\
Prasinophycean Algae & Cymatiosphaera sp. 2 & 7 \\
Pterospermella & & 2 \\
Red Algae & Beringiella sp. & 26 \\
Zooplankton & Tintinnid loricae & 16 \\
& Tintinnid cyst & 1 \\
& Zooplankton sp. & 248 \\
Foraminiferan linings & & 196 \\
Insect parts & & 28 \\
& &
\end{tabular}

\section{Sample 186-15}

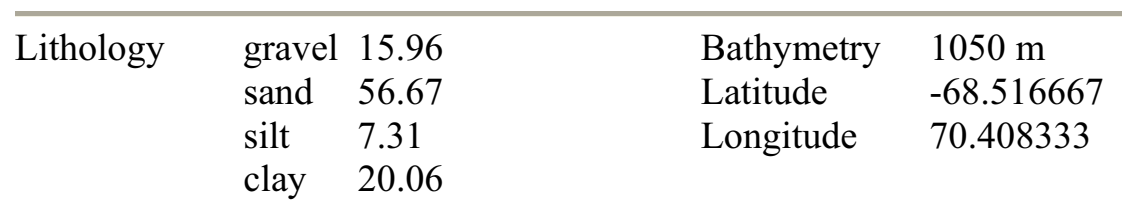

\section{Palynomorphs Count}

Acritarchs

Sphaeoromorphs

Prasinophyte Algae

Cymatiosphaera sp. 2

4

Egg Cases

Pollen

Red Algae

Egg cases

Pollen

Zooplankton

Beringiella sp.

Tintinnid loricae

Tintinnid cyst 1

Zooplankton spp. $\quad 106$

Foraminiferan linings

Insect parts

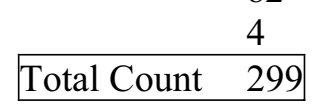




\begin{tabular}{llll}
\hline Sample & \multicolumn{1}{l}{$\mathbf{1 8 6 - 1 6}$} & & \\
\hline Lithology & gravel 17.27 & Bathymetry & $726 \mathrm{~m}$ \\
& sand 46.28 & Latitude & -68.375 \\
& silt 19.33 & Longitude & 71.306667 \\
& clay 17.12 & & \\
& & &
\end{tabular}

\begin{tabular}{lll}
\multicolumn{1}{c}{ Palynomorphs } & Count & \\
Unknowns & Unknown sp. 3 & 1 \\
& Unknown sp. 6 & 1 \\
Acritarchs & Sphaeoromorphs & 7 \\
Prasinophyte algae & Cymatiosphaera sp. 2 & 2 \\
Egg Cases & Egg cases & 18 \\
Pollen & Pollen & 1 \\
Red Algae & Beringiella sp. & 18 \\
Zooplankton & Tintinnid loricae & 10 \\
& Tintinnid cyst & 1 \\
Foraminiferan linings & Zooplankton spp. & 302 \\
Insect parts & & 254 \\
& & 29 \\
& &
\end{tabular}

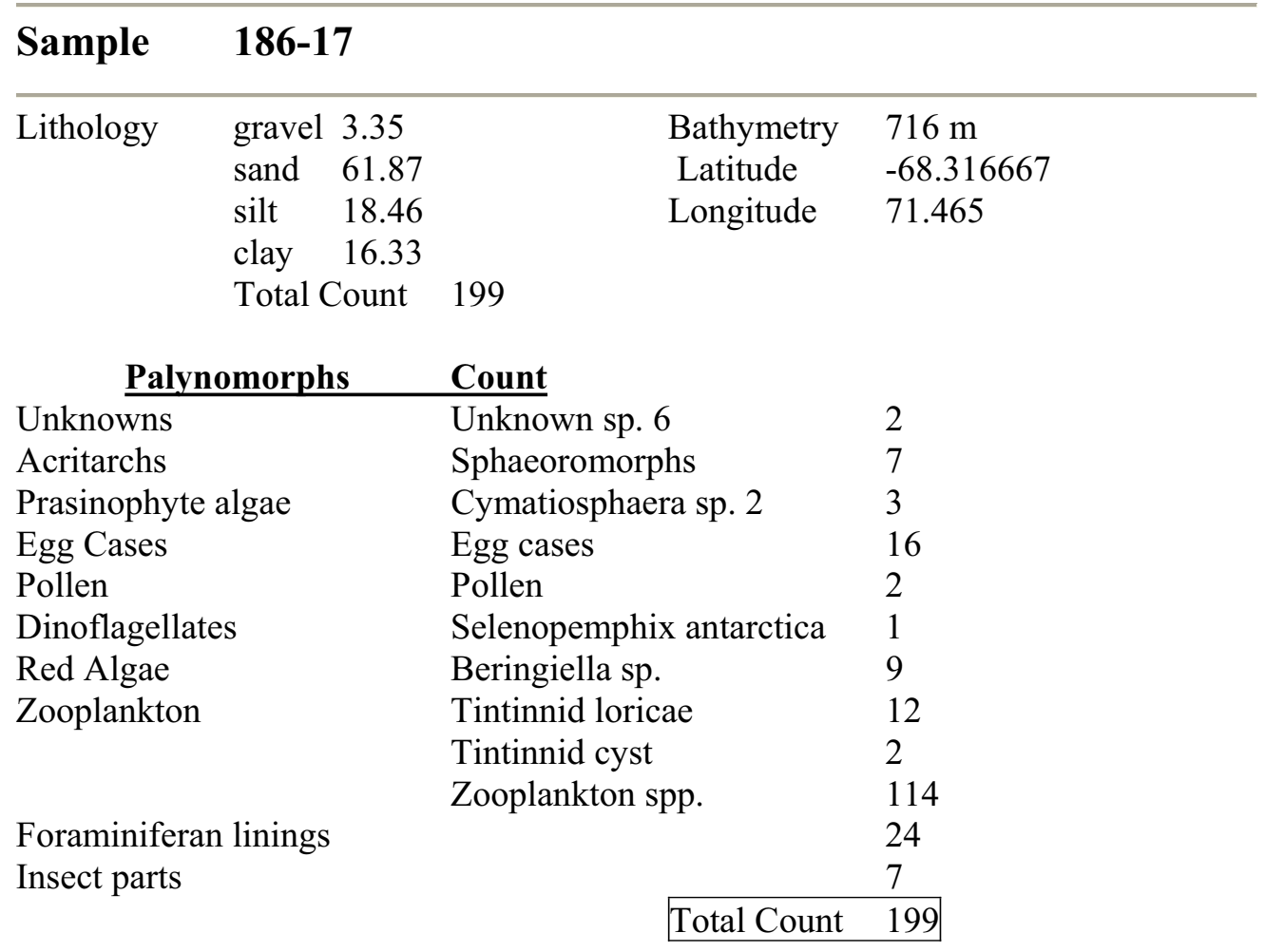




\begin{tabular}{|c|c|c|c|}
\hline Sample & $186-18$ & & \\
\hline Lithology & $\begin{array}{ll}\text { gravel } & 0.44 \\
\text { sand } & 52.27 \\
\text { silt } & 15.82 \\
\text { clay } & 31.47\end{array}$ & $\begin{array}{l}\text { Bathymetry } \\
\text { Latitude } \\
\text { Longitude }\end{array}$ & $\begin{array}{l}608 \mathrm{~m} \\
-68.145 \\
72.02\end{array}$ \\
\hline
\end{tabular}

\section{Palynomorphs Count}

Acritarchs

Acritarch spp. 4

Prasinophyte algae

Cymatiosphaera sp. $2 \quad 11$

Egg Cases

Pollen

Egg cases 3

Red Algae

Pollen

3

Zooplankton

Beringiella sp.

Zooplankton sp.

3

Foraminiferan linings

Insect parts

\begin{tabular}{ll} 
& 60 \\
& 4 \\
\hline Total Count & 150 \\
\hline
\end{tabular}

\begin{tabular}{|c|c|c|c|}
\hline Sample & 186-19 & & \\
\hline Lithology & $\begin{array}{ll}\text { gravel } & 10.48 \\
\text { sand } & 23.79 \\
\text { silt } & 30.45 \\
\text { clay } & 35.27\end{array}$ & $\begin{array}{l}\text { Bathymetry } \\
\text { Latitude } \\
\text { Longitude }\end{array}$ & $\begin{array}{l}775 \mathrm{~m} \\
-68.15 \\
72.166667\end{array}$ \\
\hline
\end{tabular}

\section{Palynomorphs}

Unknowns

Prasinophyte algae

Egg Cases

Pollen

Red Algae

Zooplankton

Foraminiferan linings

Insect parts

\section{Count}

Unknown sp. 6

Cymatiosphaera spp. $2 \quad 8$

Egg cases 7

Pollen 10

Beringiella sp. $\quad 11$

Tintinnid loricae 3

Zooplankton spp. $\quad 130$

Total Count 273 


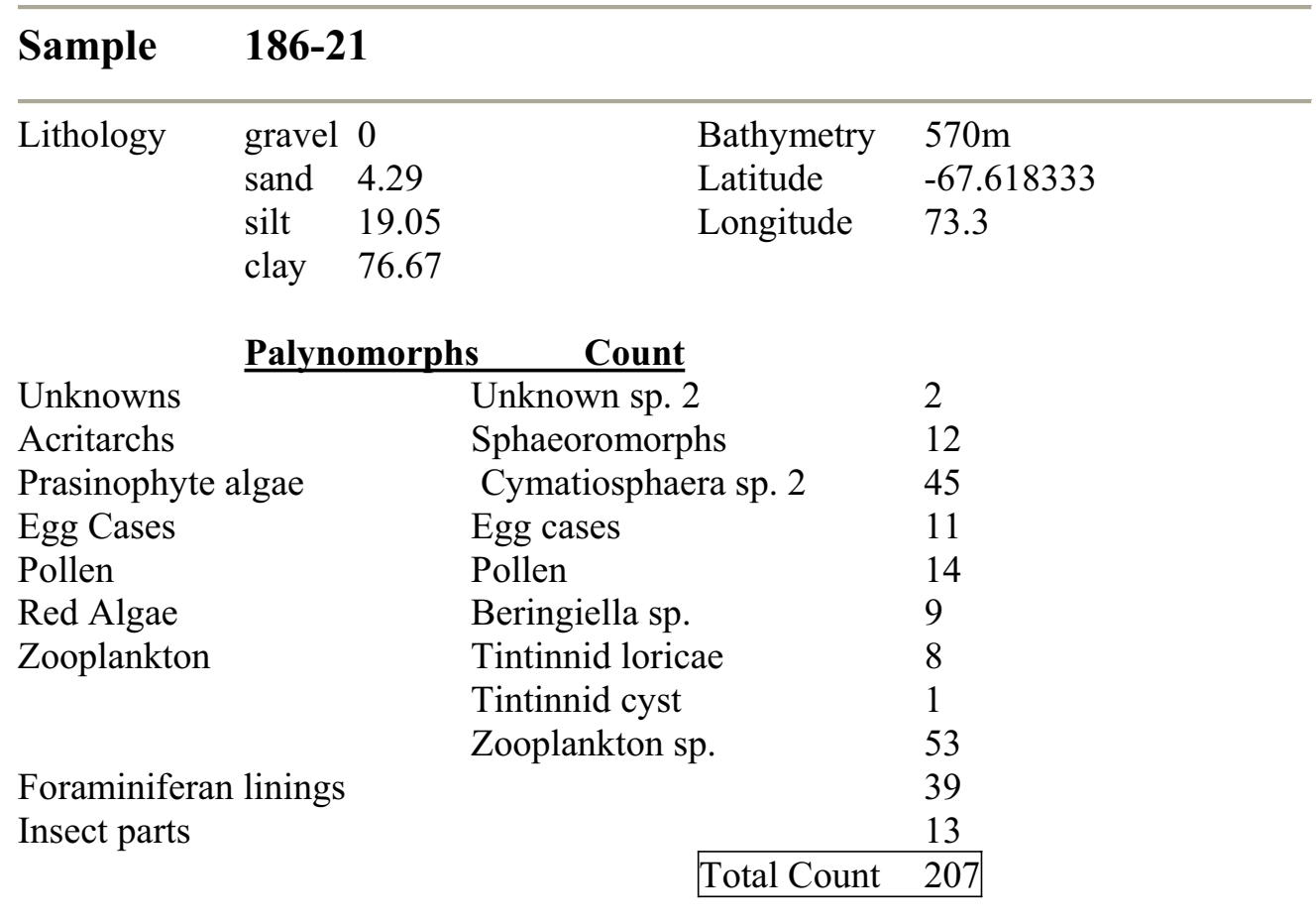

\begin{tabular}{|c|c|c|c|}
\hline Sample & $186-22$ & & \\
\hline Lithology & $\begin{array}{ll}\text { gravel } & 0 \\
\text { sand } & 11.8 \\
\text { silt } & 29.81 \\
\text { clay } & 58.39\end{array}$ & $\begin{array}{l}\text { Bathymetry } \\
\text { Latitude } \\
\text { Longitude }\end{array}$ & $\begin{array}{l}660 \mathrm{~m} \\
-67.691667 \\
72.216667\end{array}$ \\
\hline
\end{tabular}

\section{Palynomorphs Count}

$\begin{array}{lll}\text { Unknowns } & \text { Unknown sp. 1 } & 1 \\ & \text { Unknown sp. 3 } & 1 \\ & \text { Unknown sp. 6 } & 4 \\ \text { Acritarchs } & \text { Acritarch sp. 3 } & 3 \\ & \text { Sphaeoromorphs } & 14 \\ \text { Prasinophyte algae } & \text { Cymatiosphaera sp. 2 } & 8 \\ \text { Dinoflagellates } & \text { Selenopemphix antarctica } & 48 \\ & \text { Cryodinium sp. } & 5 \\ & \text { Protoperidinium sp. 2 } & 24 \\ \text { Egg Cases } & \text { Egg cases } & 48 \\ \text { Pollen } & \text { Pollen } & 27 \\ \text { Red Algae } & \text { Beringiella sp. } & 91 \\ \text { Zooplankton } & \text { Tintinnid loricae } & 8 \\ & \text { Zooplankton spp. } & 370 \\ \text { Foraminiferan linings } & & 296 \\ \text { Insect parts } & & 66 \\ & & \text { Total Count } \\ & & 1014\end{array}$




\begin{tabular}{llll}
\hline Sample & $\mathbf{1 8 6 - 2 6}$ & & \\
\hline Lithology & gravel 12.54 & Bathymetry & $390 \mathrm{~m}$ \\
& sand 64.68 & Latitude & -67.131666 \\
& silt 13.45 & Longitude & 70.795 \\
& clay 9.32 & & \\
\hline
\end{tabular}

\begin{tabular}{lll}
\multicolumn{1}{c}{ Palynomorphs } & Count & \\
Acritarchs & Sphaeoromorphs & 1 \\
Prasinophyte algae & Cymatiosphaera sp. 2 & 1 \\
Egg Cases & Egg cases & 10 \\
Pollen & Pollen & 4 \\
Red Algae & Beringiella sp. & 6 \\
Zooplankton & Tintinnid loricae & 9 \\
& Zooplankton sp. & 141 \\
Foraminiferan linings & & 115 \\
Insect parts & & 3 \\
& &
\end{tabular}

\section{Sample 186-27}

\begin{tabular}{lclll}
\hline Lithology & gravel & & Bathymetry & $436 \mathrm{~m}$ \\
& sand & 36.36 & Latitude & -67.168667 \\
silt & 30.98 & Longitude & 74.503333 \\
clay & 32.65 & &
\end{tabular}

\section{Palynomorphs Count}

$\begin{array}{lll}\text { Acritarchs } & \text { Sphaeoromorphs } & 1 \\ \text { Dinoflagellates } & \text { Alterbidinium asymmetrica } & 3 \\ & \text { Alisocysta sp. } & 1 \\ & \text { Deflandrea sp. } & 1 \\ & \text { Spinodinium macmurdoense } & 1 \\ \text { Egg Cases } & \text { Egg cases } & 1 \\ \text { Pollen } & \text { Pollen } & 63 \\ \text { Red Algae } & \text { Beringiella sp. } & 3 \\ \text { Zooplankton } & \text { Zooplankton sp. } & 9 \\ \text { Foraminiferan linings } & & 11 \\ \text { Insect parts } & & 4 \\ & & \text { Total Count } \\ \end{array}$




\begin{tabular}{llll}
\hline Sample & \multicolumn{1}{l}{$\mathbf{1 8 6 - 2 8}$} & & \\
\hline Lithology & gravel 15.65 & Bathymetry & $338 \mathrm{~m}$ \\
& sand 36.52 & Latitude & -67.268333 \\
& silt 20.63 & Longitude & 76.398333 \\
& clay 27.21 & & \\
& & &
\end{tabular}

\section{Palynomorphs Count}

Prasinophyte algae

Dinoflagellates

Egg Cases

Pollen

Red Algae

Zooplankton

Foraminiferan linings

Insect parts
Cymatiosphaera sp. 2

Operculum 3

Turbiosphaera filosa 2

Alterbidinium asymmetrica 1

Enneadocysta partridgei 1

Egg cases 1

Pollen 55

Beringiella sp. 6

Zooplankton sp. 25

4

9

Total Count 108

\section{Sample 186-29}

\begin{tabular}{lllll}
\hline Lithology & gravel & 6.85 & Bathymetry & $1230 \mathrm{~m}$ \\
& sand & 40.36 & Latitude & -66.5 \\
& silt & 21.08 & Longitude & 72.275 \\
& clay & 31.71 & & \\
& & &
\end{tabular}

\section{Palynomorphs Count}

Acritarchs

Dinoflagellates

Egg Cases

Pollen

Red Algae

Foraminiferan linings
Acritarch spp. 1

Spinodinium spp. 2

Deflandrea spp. 1

Egg cases 1

Pollen 41

Beringiella sp. 2

\begin{tabular}{ll} 
& 8 \\
\hline Total Count & 58 \\
\hline
\end{tabular} 


\begin{tabular}{|c|c|c|c|}
\hline Sample & $186-31$ & & \\
\hline Lithology & $\begin{array}{ll}\text { gravel } & 0 \\
\text { sand } & 3.08 \\
\text { silt } & 25.59 \\
\text { clay } & 71.33\end{array}$ & $\begin{array}{l}\text { Bathymetry } \\
\text { Latitude } \\
\text { Longitude }\end{array}$ & $\begin{array}{l}1625 \mathrm{~m} \\
-66.401667 \\
72.285\end{array}$ \\
\hline
\end{tabular}

\section{Palynomorphs Count}

\begin{tabular}{|c|c|}
\hline Dinoflagellates & Enneadocysta partridgei \\
\hline Pollen & Pollen \\
\hline
\end{tabular}

\begin{tabular}{|c|c|c|c|}
\hline Sample & 186-32 & & \\
\hline Lithology & $\begin{array}{ll}\text { gravel } & 0.9 \\
\text { sand } & 9.19 \\
\text { silt } & 28.92 \\
\text { clay } & 60.99\end{array}$ & $\begin{array}{l}\text { Bathymetry } \\
\text { Latitude } \\
\text { Longitude }\end{array}$ & $\begin{array}{l}565 \mathrm{~m} \\
-66.318333 \\
72.258333\end{array}$ \\
\hline
\end{tabular}

\section{Palynomorphs Count}

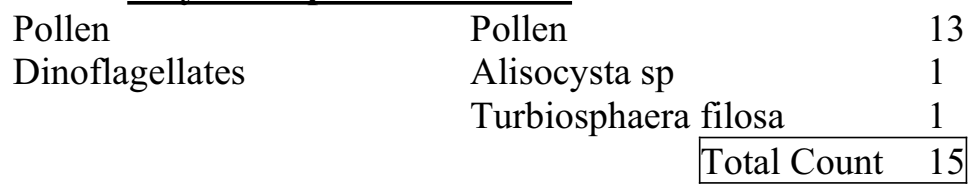


PALYNOMORPH DISTRIBUTION TABLES 3.2a

Raw Count
\begin{tabular}{|l|r|r|r|r|r|}
\hline Total Holocene & \multicolumn{1}{|c|}{ Fan } & N shelf & M shelf & Coastal & Total \\
\hline Acritarchs & 10 & 54 & 230 & 38 & 332 \\
\hline Holocene Dinocysts & 1 & 10 & 155 & 2 & 168 \\
\hline Prasinophycean Algae & 2 & 30 & 261 & 127 & 420 \\
\hline Red Algae & 6 & 84 & 319 & 101 & 510 \\
\hline Egg Cases & 3 & 85 & 273 & 72 & 433 \\
\hline Zooplankton & 3 & 703 & 2,371 & 927 & 4,004 \\
\hline Foraminifera Linings & 13 & 1,237 & 1,408 & 768 & 3,426 \\
\hline Insect Parts & 2 & 162 & 420 & 125 & 709 \\
\hline Unknowns & 1 & 31 & 35 & 28 & 95 \\
\hline & 41 & 2,396 & 5,472 & 2,188 & 10,097 \\
\hline Dry Weight & 149.34 & 116.17 & 63.97 & 35.85 & 365.33 \\
\hline Grains per Gram Holocene & 0.41 & 30.94 & 128.31 & 91.55 & 41.46 \\
\hline
\end{tabular}

Raw Count

\begin{tabular}{|l|r|r|r|r|r|}
\hline Total Reworked & \multicolumn{1}{|c|}{ Fan } & N shelf & M shelf & Coastal & Total \\
\hline Reworked Dinocysts & 21 & 34 & 1 & 1 & 57 \\
\hline Pollen Total Reworked & 1,286 & 1,077 & 176 & 34 & 2,573 \\
\hline Dry Weight & 1,307 & 1,111 & 177 & 35 & 2,630 \\
\hline Grains per Gram & 149.34 & 116.17 & 63.97 & 35.85 & 365.33 \\
\hline
\end{tabular}

Raw Count

\begin{tabular}{|c|c|c|c|c|c|}
\hline Marine Palynomorphs & Fan & $\mathrm{N}$ shelf & Mid shelf & Coastal & Total \\
\hline Acritarchs & 10 & 54 & 230 & 38 & 332 \\
\hline Holocene Dinocysts & 1 & 10 & 155 & 2 & 168 \\
\hline Prasinophycean Algae & 2 & 30 & 261 & 127 & 420 \\
\hline Red Algae & 6 & 84 & 319 & 101 & 510 \\
\hline Total & 19 & 178 & 965 & 268 & 1,430 \\
\hline Dry Weight & 149.34 & 116.17 & 63.97 & 35.85 & 365.33 \\
\hline Grains per Gram & 0.19 & 2.30 & 22.63 & 11.21 & 5.87 \\
\hline
\end{tabular}

\section{Raw Count}

\begin{tabular}{|c|c|c|c|c|c|}
\hline Holocene Dinocysts & Fan & $\mathrm{N}$ shelf & Mid shelf & Coastal & Totals \\
\hline Alisocysta sp & 1 & 1 & \begin{tabular}{r|}
1 \\
\end{tabular} & 0 & 3 \\
\hline Cryodinium sp & 0 & 0 & 11 & 0 & 11 \\
\hline \begin{tabular}{|l|} 
Dinocyst spp \\
\end{tabular} & 0 & 0 & 1 & 0 & 1 \\
\hline Hystrichosphaeridium spp & 0 & 4 & 0 & 0 & 4 \\
\hline Impagidinium sp & 0 & 1 & 0 & 0 & \\
\hline Protoperidinium sp 1 & 0 & 1 & 0 & 0 & 1 \\
\hline Protoperidinium sp 2 & 0 & 3 & 33 & 1 & 37 \\
\hline Selenopemphix antarctica & 0 & 0 & 109 & 1 & 110 \\
\hline Total & 1 & 10 & 155 & 2 & 168 \\
\hline Dry Weight & 149.34 & 116.17 & 63.97 & 35.85 & 365.33 \\
\hline Grains per Gram & 0.01 & 0.13 & 3.63 & 0.08 & 0.69 \\
\hline
\end{tabular}

Raw Count
\begin{tabular}{|l|r|r|r|r|r|}
\hline Reworked Dinocysts & \multicolumn{1}{|c|}{ Fan } & N shelf & Mid shelf & Coastal & Totals \\
\hline Alterbitedinium asymmetrica & 3 & 5 & 0 & 0 & 8 \\
\hline Deflandrea spp & 2 & 2 & 1 & 0 & 5 \\
\hline Enneadocysta partridgei & 1 & 2 & 0 & 0 & 3 \\
\hline Operculum & 7 & 11 & 0 & 0 & 18 \\
\hline Spinidinium macmurdoense & 1 & 2 & 0 & 0 & 3 \\
\hline Spinidinium spp & 2 & 1 & 0 & 0 & 3 \\
\hline Turbiosphaera filosa & 3 & 3 & 0 & 1 & 7 \\
\hline Vozzhennikovia spp & 2 & 8 & 0 & 0 & 10 \\
\hline & 21 & 34 & 1 & 1 & 57 \\
\hline Dry Weight & 149.34 & 116.17 & 63.97 & 35.85 & 365.33 \\
\hline Grains per Gram & 0.21 & 0.44 & 0.02 & 0.04 & 0.23 \\
\hline
\end{tabular}


Raw Count Continued

\begin{tabular}{|c|c|c|c|c|c|}
\hline Acritarchs & Fan & $\mathrm{N}$ shelf & Mid shelf & Coastal & Totals \\
\hline Acritarch spp 1 & 5 & 0 & 0 & 0 & 5 \\
\hline Acritarch spp 2 & 0 & 0 & 2 & 0 & 2 \\
\hline Acritarch spp 3 & 0 & 0 & 3 & 0 & 3 \\
\hline Acritarch spp 4 & 0 & 0 & 9 & 0 & 9 \\
\hline Leiospherida $\mathrm{sp}$ & 1 & 2 & 22 & 0 & 25 \\
\hline Leiospherida sigmopolis & 3 & 0 & 0 & 0 & 3 \\
\hline Sphaeoromorphs & 1 & 52 & 194 & 38 & 285 \\
\hline Total & 10 & 54 & 230 & 38 & 332 \\
\hline Dry Weight & 149.34 & 116.17 & 63.97 & 35.85 & 365.33 \\
\hline Grains per Gram & 0.10 & 0.70 & 5.39 & 1.59 & 1.36 \\
\hline
\end{tabular}

\section{Raw Count}

\begin{tabular}{|c|c|c|c|c|c|}
\hline Prasinophycean Algae & Fan & $\mathrm{N}$ shelf & Mid shelf & Coastal & Totals \\
\hline Cymatiosphaera spp 1 & 1 & 5 & 0 & 0 & 6 \\
\hline Cymatiosphaera spp 2 & 0 & 15 & 254 & 127 & 396 \\
\hline Pterospermella & 1 & 9 & 6 & 0 & 16 \\
\hline Tasmanites & 0 & 1 & 1 & 0 & 2 \\
\hline Total & 2 & 30 & 261 & 127 & 420 \\
\hline Dry Weight & 149.34 & 116.17 & 63.97 & 35.85 & 365.33 \\
\hline Grains per Gram & 0.02 & 0.39 & 6.12 & 5.31 & 1.72 \\
\hline
\end{tabular}

Raw Count
\begin{tabular}{|lr|r|r|r|r|r|}
\hline Red Algae & Fan & N shelf & Mid shelf & Coastal & Totals \\
\hline Beringiella sp & 6 & 84 & 319 & 101 & 510 \\
\hline & Total & 6 & 84 & 319 & 101 & 510 \\
\hline Dry Weight & 149.34 & 116.17 & 63.97 & 35.85 & 365.33 \\
\hline Grains per Gram & 0.06 & 1.08 & 7.48 & 4.23 & 2.09 \\
\hline
\end{tabular}

\section{Raw Count}

\begin{tabular}{|c|c|c|c|c|c|}
\hline Zooplankton & Fan & $\mathrm{N}$ shelf & Mid shelf & Coastal & Totals \\
\hline Tintinnid cyst & 0 & 0 & 33 & 13 & 46 \\
\hline Tintinnid loricae & 0 & 46 & 149 & 38 & 233 \\
\hline Zooplankton spp & 3 & 657 & 2,189 & 876 & 3,725 \\
\hline Total & 3 & 703 & 2,371 & 927 & 4,004 \\
\hline Dry Weight & 149.34 & 116.17 & 63.97 & 35.85 & 365.33 \\
\hline Grains per Gram & 0.03 & 9.08 & 55.60 & 38.79 & 16.44 \\
\hline
\end{tabular}

\section{Raw Count}

\begin{tabular}{|c|c|c|c|c|c|}
\hline Insect parts & Fan & $\mathrm{N}$ shelf & Mid shelf & Coastal & Totals \\
\hline Insect parts & 2 & 162 & 420 & 125 & 709 \\
\hline Total & 2 & 162 & 420 & 125 & 709 \\
\hline Dry Weight & 149.34 & 116.17 & 63.97 & 35.85 & 365.33 \\
\hline Grains per Gram & 0.02 & 2.09 & 9.85 & 5.23 & 2.91 \\
\hline
\end{tabular}

Raw Count

\begin{tabular}{|c|c|c|c|c|c|}
\hline Foraminifera linings & Fan & $\mathrm{N}$ shelf & Mid shelf & Coastal & Totals \\
\hline Foraminifera linings & 13 & 1,237 & 1,408 & 768 & 3,426 \\
\hline Total & 13 & 1,237 & 1,408 & 768 & 3,426 \\
\hline Dry Weight & 149.34 & 116.17 & 63.97 & 35.85 & 365.33 \\
\hline Grains per Gram & 0.13 & 15.97 & 33.02 & 32.13 & 14.07 \\
\hline
\end{tabular}

Raw Count

\begin{tabular}{|c|c|c|c|c|c|}
\hline Egg cases & Fan & $\mathrm{N}$ shelf & Mid shelf & Coastal & Totals \\
\hline Egg cases & 3 & 85 & 273 & 72 & 433 \\
\hline Total & 3 & 85 & 273 & 72 & 433 \\
\hline Dry Weight & 149.34 & 116.17 & 63.97 & 35.85 & 365.33 \\
\hline Grains per Gram & 0.03 & 1.10 & 6.40 & 3.01 & 1.78 \\
\hline
\end{tabular}


Raw Count Continued

\begin{tabular}{|l|r|r|r|r|r|}
\hline Unknowns & \multicolumn{1}{|c|}{ Fan } & N shelf & Mid shelf & Coastal & Totals \\
\hline Unknown sp 1 & 0 & 3 & 2 & 1 & 6 \\
\hline Unknown sp 2 & 0 & 0 & 7 & 0 & 7 \\
\hline Unknown sp 3 & 0 & 3 & 9 & 1 & 13 \\
\hline Unknown sp 4 & 0 & 1 & 3 & 2 & 6 \\
\hline Unknown sp 5 & 0 & 0 & 2 & 0 & 2 \\
\hline Unknown sp 6 & 1 & 13 & 11 & 19 & 44 \\
\hline Unknown sp 7 & 0 & 6 & 0 & 3 & 9 \\
\hline Unknown sp 8 & 0 & 2 & 0 & 1 & 3 \\
\hline Unknown sp 9 & 0 & 3 & 1 & 1 & 5 \\
\hline & 1 & 31 & 35 & 28 & 95 \\
\hline Dry Weight & 149.34 & 116.17 & 63.97 & 35.85 & 365.33 \\
\hline Grains per Gram & 0.01 & 0.40 & 0.82 & 1.17 & 0.39 \\
\hline
\end{tabular}

Raw Count

\begin{tabular}{|l|r|r|r|r|}
\hline Total Holocene N Shelf & NE shelf & N shelf & NW shelf & Total \\
\hline Acritarchs & 2 & 10 & 42 & 54 \\
\hline Holocene Dinocysts & 1 & 5 & 4 & 10 \\
\hline Prasinophycean Algae & 7 & 5 & 18 & 30 \\
\hline Red Algae & 22 & 21 & 41 & 84 \\
\hline Egg Cases & 8 & 20 & 57 & 85 \\
\hline Zooplankton & 60 & 254 & 389 & 703 \\
\hline Foraminifera Linings & 30 & 236 & 971 & 1,237 \\
\hline Insect Parts & 16 & 46 & 100 & 162 \\
\hline Unknowns & 1 & 7 & 23 & 31 \\
\hline & 147 & 604 & 1,645 & 2,396 \\
\hline Dry Weight & 20.26 & 47.07 & 48.84 & 116.17 \\
\hline Grains per Gram & 10.88 & 19.25 & 50.52 & 30.94 \\
\hline
\end{tabular}

\section{Raw Count}

\begin{tabular}{|l|l|l|l|l|}
\hline Dinocysts N Shelf & NE shelf & N shelf & NW shelf & Total \\
\hline
\end{tabular}

\begin{tabular}{|l|r|r|r|r|}
\hline Dinocysts N Shelf & NE shelf & N shelf & NW shelf & \multicolumn{1}{|c|}{ Total } \\
\hline Alisocysta sp & 0 & 1 & 0 & 1 \\
\hline Cryodinium sp & 0 & 0 & 0 & 0 \\
\hline Dinocyst spp & 0 & 0 & 0 & 0 \\
\hline Hystrichosphaeridium spp & 0 & 4 & 0 & 4 \\
\hline Impagidinium sp & 1 & 0 & 0 & 1 \\
\hline Protoperidinium sp 1 & 0 & 0 & 1 & 1 \\
\hline Protoperidinium sp 2 & 0 & 0 & 3 & 3 \\
\hline Selenopemphix antarctica & 0 & 0 & 0 & 0 \\
\hline Alterbitedinium asymmetrica & 1 & 4 & 0 & 5 \\
\hline Deflandrea spp & 0 & 1 & 1 & 2 \\
\hline Enneadocysta partridgei & 1 & 1 & 0 & 2 \\
\hline Operculum & 4 & 4 & 3 & 11 \\
\hline Spinidinium macmurdoense & 1 & 1 & 0 & 2 \\
\hline Spinidinium spp & 0 & 1 & 0 & 1 \\
\hline Turbiosphaera filosa & 2 & 1 & 0 & 3 \\
\hline Vozzhennikovia spp & 0 & 8 & 0 & 8 \\
\hline & 10 & 26 & 8 & 44 \\
\hline Dry Weight & 20.26 & 47.07 & 48.84 & 116.17 \\
\hline Grains per Gram & 0.74 & 0.83 & 0.25 & 0.57 \\
\hline
\end{tabular}

Raw Count

\begin{tabular}{|c|c|c|c|c|c|}
\hline Dinocysts & Fan & $\mathrm{N}$ shelf & Mid shelf & Coastal & Total \\
\hline Holocene & 1 & 10 & 155 & 2 & 168 \\
\hline Reworked & 21 & 34 & 1 & 1 & 57 \\
\hline Total & 22 & 44 & 156 & 3 & 225 \\
\hline Dry Weight & 149.34 & 116.17 & 63.97 & 35.85 & 365.33 \\
\hline & 0.22 & 0.57 & 3.66 & 0.13 & 0.92 \\
\hline
\end{tabular}


PALYNOMORPH DISTRIBUTION TABLES 3.2b

Percentages
\begin{tabular}{|l|r|r|r|r|r|}
\hline Total Holocene & \multicolumn{1}{|c|}{ Fan } & N shelf & Mid shelf & Coastal & Total \\
\hline Acritarchs & $24.39 \%$ & $2.25 \%$ & $4.20 \%$ & $1.74 \%$ & $3.29 \%$ \\
\hline Holocene Dinocysts & $2.44 \%$ & $0.42 \%$ & $2.83 \%$ & $0.09 \%$ & $1.66 \%$ \\
\hline Prasinophycean Algae & $4.88 \%$ & $1.25 \%$ & $4.77 \%$ & $5.80 \%$ & $4.16 \%$ \\
\hline Red Algae & $14.63 \%$ & $3.51 \%$ & $5.83 \%$ & $4.62 \%$ & $5.05 \%$ \\
\hline Egg Cases & $7.32 \%$ & $3.55 \%$ & $4.99 \%$ & $3.29 \%$ & $4.29 \%$ \\
\hline Zooplankton & $7.32 \%$ & $29.34 \%$ & $43.33 \%$ & $42.37 \%$ & $39.66 \%$ \\
\hline Foraminifera Linings & $31.71 \%$ & $51.63 \%$ & $25.73 \%$ & $35.10 \%$ & $33.93 \%$ \\
\hline Insect Parts & $4.88 \%$ & $6.76 \%$ & $7.68 \%$ & $5.71 \%$ & $7.02 \%$ \\
\hline Unknowns & $2.44 \%$ & $1.29 \%$ & $0.64 \%$ & $1.28 \%$ & $0.94 \%$ \\
\hline
\end{tabular}

Percentages

\begin{tabular}{|l|r|r|r|r|r|}
\hline Total Reworked & \multicolumn{1}{|c|}{ Fan } & N shelf & M shelf & \multicolumn{1}{c|}{ Coastal } & Total \\
\hline Reworked Dinocysts & $1.61 \%$ & $3.06 \%$ & $0.56 \%$ & $2.86 \%$ & $2.17 \%$ \\
\hline Pollen & $98.39 \%$ & $96.94 \%$ & $99.44 \%$ & $97.14 \%$ & $97.83 \%$ \\
\hline
\end{tabular}

Percentages

\begin{tabular}{|l|r|r|r|r|c|}
\hline Marine Palynomorphs & \multicolumn{1}{|c|}{ Fan } & \multicolumn{1}{|c|}{ N shelf } & Mid shelf & Coastal & Total \\
\hline Acritarchs & $52.63 \%$ & $30.34 \%$ & $23.83 \%$ & $14.18 \%$ & $23.22 \%$ \\
\hline Holocene Dinocysts & $5.26 \%$ & $5.62 \%$ & $16.06 \%$ & $0.75 \%$ & $11.75 \%$ \\
\hline Prasinophycean Algae & $10.53 \%$ & $16.85 \%$ & $27.05 \%$ & $47.39 \%$ & $29.37 \%$ \\
\hline Red Algae & $31.58 \%$ & $47.19 \%$ & $33.06 \%$ & $37.69 \%$ & $35.66 \%$ \\
\hline
\end{tabular}

Percentages
\begin{tabular}{|l|r|r|r|r|r|}
\hline Holocene Dinocysts & Fan & N shelf & Mid shelf & Coastal & Total \\
\hline Alisocysta sp & $0.00 \%$ & $10.00 \%$ & $0.65 \%$ & $0.00 \%$ & $1.79 \%$ \\
\hline Cryodinium sp & $0.00 \%$ & $0.00 \%$ & $7.10 \%$ & $0.00 \%$ & $6.55 \%$ \\
\hline Dinocyst spp & $0.00 \%$ & $0.00 \%$ & $0.65 \%$ & $0.00 \%$ & $0.60 \%$ \\
\hline Hystrichosphaeridium spp & $0.00 \%$ & $40.00 \%$ & $0.00 \%$ & $0.00 \%$ & $2.38 \%$ \\
\hline Impagidinium sp & $0.00 \%$ & $10.00 \%$ & $0.00 \%$ & $0.00 \%$ & $0.60 \%$ \\
\hline Protoperidinium sp 1 & $0.00 \%$ & $10.00 \%$ & $0.00 \%$ & $0.00 \%$ & $0.60 \%$ \\
\hline Protoperidinium sp 2 & $0.00 \%$ & $30.00 \%$ & $21.29 \%$ & $50.00 \%$ & $22.02 \%$ \\
\hline Selenopemphix antarctica & $0.00 \%$ & $0.00 \%$ & $70.32 \%$ & $50.00 \%$ & $65.48 \%$ \\
\hline
\end{tabular}

Percentages
\begin{tabular}{|l|r|r|r|r|r|}
\hline Reworked Dinocysts & \multicolumn{1}{|c|}{ Fan } & N shelf & Mid shelf & Coastal & Totals \\
\hline Alterbitedinium asymmetrica & $14.29 \%$ & $14.71 \%$ & $0.00 \%$ & $0.00 \%$ & $14.04 \%$ \\
\hline Deflandrea spp & $9.52 \%$ & $5.88 \%$ & $100.00 \%$ & $0.00 \%$ & $8.77 \%$ \\
\hline Enneadocysta partridgei & $4.76 \%$ & $5.88 \%$ & $0.00 \%$ & $0.00 \%$ & $5.26 \%$ \\
\hline Operculum & $33.33 \%$ & $32.35 \%$ & $0.00 \%$ & $0.00 \%$ & $31.58 \%$ \\
\hline Spinidinium macmurdoense & $4.76 \%$ & $5.88 \%$ & $0.00 \%$ & $0.00 \%$ & $5.26 \%$ \\
\hline Spinidinium spp & $9.52 \%$ & $2.94 \%$ & $0.00 \%$ & $0.00 \%$ & $5.26 \%$ \\
\hline Turbiosphaera filosa & $14.29 \%$ & $8.82 \%$ & $0.00 \%$ & $100.00 \%$ & $12.28 \%$ \\
\hline Vozzhennikovia spp & $9.52 \%$ & $23.53 \%$ & $0.00 \%$ & $0.00 \%$ & $17.54 \%$ \\
\hline
\end{tabular}


Percentages Continued

\begin{tabular}{|l|r|r|r|r|r|}
\hline Acritarchs & \multicolumn{1}{|c|}{ Fan } & N shelf & Mid shelf & Coastal & Totals \\
\hline Acritarch spp 1 & $50.00 \%$ & $0.00 \%$ & $0.00 \%$ & $0.00 \%$ & $1.51 \%$ \\
\hline Acritarch spp 2 & $0.00 \%$ & $0.00 \%$ & $0.87 \%$ & $0.00 \%$ & $0.60 \%$ \\
\hline Acritarch spp 3 & $0.00 \%$ & $0.00 \%$ & $1.30 \%$ & $0.00 \%$ & $0.90 \%$ \\
\hline Acritarch spp 4 & $0.00 \%$ & $0.00 \%$ & $3.91 \%$ & $0.00 \%$ & $2.71 \%$ \\
\hline Leiospherida sp & $10.00 \%$ & $3.70 \%$ & $9.57 \%$ & $0.00 \%$ & $7.53 \%$ \\
\hline Leiospherida sigmopolis & $30.00 \%$ & $0.00 \%$ & $0.00 \%$ & $0.00 \%$ & $0.90 \%$ \\
\hline Sphaeoromorphs & $10.00 \%$ & $96.30 \%$ & $84.35 \%$ & $100.00 \%$ & $85.84 \%$ \\
\hline
\end{tabular}

Percentages

\begin{tabular}{|l|r|r|r|r|r|}
\hline Prasinophycean Algae & \multicolumn{1}{|c|}{ Fan } & N shelf & Mid shelf & Coastal & \multicolumn{1}{c|}{ Totals } \\
\hline Cymatiosphaera spp 1 & $50.00 \%$ & $16.67 \%$ & $0.00 \%$ & $0.00 \%$ & $1.43 \%$ \\
\hline Cymatiosphaera spp 2 & $0.00 \%$ & $50.00 \%$ & $97.32 \%$ & $100.00 \%$ & $94.29 \%$ \\
\hline Pterospermella & $50.00 \%$ & $30.00 \%$ & $2.30 \%$ & $0.00 \%$ & $3.81 \%$ \\
\hline Tasmanites & $0.00 \%$ & $3.33 \%$ & $0.38 \%$ & $0.00 \%$ & $0.48 \%$ \\
\hline
\end{tabular}

Percentages

\begin{tabular}{|l|c|c|c|c|c|}
\hline Red Algae & Fan & $\mathrm{N}$ shelf & Mid shelf & Coastal & Totals \\
\hline
\end{tabular}

\begin{tabular}{|l|c|c|c|c|c|}
\hline Beringiella sp & $100.00 \%$ & $100.00 \%$ & $100.00 \%$ & $100.00 \%$ & $100.00 \%$ \\
\hline
\end{tabular}

Percentages

Percentages
\begin{tabular}{|l|r|r|r|r|r|}
\hline Zooplankton & Fan & N shelf & Mid shelf & Coastal & Totals \\
\hline Tintinnid cyst & $0.00 \%$ & $0.00 \%$ & $1.39 \%$ & $1.40 \%$ & $1.15 \%$ \\
\hline Tintinnid loricae & $0.00 \%$ & $6.54 \%$ & $6.28 \%$ & $4.10 \%$ & $5.82 \%$ \\
\hline Zooplankton spp & $100.00 \%$ & $93.46 \%$ & $92.32 \%$ & $94.50 \%$ & $93.03 \%$ \\
\hline
\end{tabular}

Percentages

\begin{tabular}{|l|c|c|c|c|c|}
\hline Insect parts & Fan & $\mathrm{N}$ shelf & Mid shelf & Coastal & Totals \\
\hline
\end{tabular}

\begin{tabular}{|l|c|c|c|c|c|}
\hline Insect parts & $100.00 \%$ & $100.00 \%$ & $100.00 \%$ & $100.00 \%$ & $100.00 \%$ \\
\hline
\end{tabular}

Percentages

\begin{tabular}{|l|c|c|c|c|c|}
\hline Foraminifera linings & Fan & $\mathrm{N}$ shelf & Mid shelf & Coastal & Totals \\
\hline
\end{tabular}

\begin{tabular}{|l|c|c|c|c|c|}
\hline Foraminifera linings & $100.00 \%$ & $100.00 \%$ & $100.00 \%$ & $100.00 \%$ & $100.00 \%$ \\
\hline
\end{tabular}

Percentages

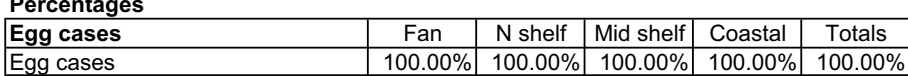


Percentages Continued

\begin{tabular}{|l|r|r|r|r|r|}
\hline Unknowns & \multicolumn{1}{|c|}{ Fan } & N shelf & Mid shelf & Coastal & \multicolumn{1}{c|}{ Totals } \\
\hline Unknown sp 1 & $0.00 \%$ & $9.68 \%$ & $5.71 \%$ & $3.57 \%$ & $6.32 \%$ \\
\hline Unknown sp 2 & $0.00 \%$ & $0.00 \%$ & $20.00 \%$ & $0.00 \%$ & $7.37 \%$ \\
\hline Unknown sp 3 & $0.00 \%$ & $9.68 \%$ & $25.71 \%$ & $3.57 \%$ & $13.68 \%$ \\
\hline Unknown sp 4 & $0.00 \%$ & $3.23 \%$ & $8.57 \%$ & $7.14 \%$ & $6.32 \%$ \\
\hline Unknown sp 5 & $0.00 \%$ & $0.00 \%$ & $5.71 \%$ & $0.00 \%$ & $2.11 \%$ \\
\hline Unknown sp 6 & $100.00 \%$ & $41.94 \%$ & $31.43 \%$ & $67.86 \%$ & $46.32 \%$ \\
\hline Unknown sp 7 & $0.00 \%$ & $19.35 \%$ & $0.00 \%$ & $10.71 \%$ & $9.47 \%$ \\
\hline Unknown sp 8 & $0.00 \%$ & $6.45 \%$ & $0.00 \%$ & $3.57 \%$ & $3.16 \%$ \\
\hline Unknown sp 9 & $0.00 \%$ & $9.68 \%$ & $2.86 \%$ & $3.57 \%$ & $5.26 \%$ \\
\hline
\end{tabular}

Percentages

\begin{tabular}{|l|r|r|r|r|}
\hline Total Holocene N Shelf & NE shelf & N shelf & NW shelf & Total \\
\hline Acritarchs & $1.36 \%$ & $1.66 \%$ & $2.55 \%$ & $2.25 \%$ \\
\hline Holocene Dinocysts & $0.68 \%$ & $0.83 \%$ & $0.24 \%$ & $0.42 \%$ \\
\hline Prasinophycean Algae & $4.76 \%$ & $0.83 \%$ & $1.09 \%$ & $1.25 \%$ \\
\hline Red Algae & $14.97 \%$ & $3.48 \%$ & $2.49 \%$ & $3.51 \%$ \\
\hline Egg Cases & $5.44 \%$ & $3.31 \%$ & $3.47 \%$ & $3.55 \%$ \\
\hline Zooplankton & $40.82 \%$ & $42.05 \%$ & $23.65 \%$ & $29.34 \%$ \\
\hline Foraminifera Linings & $20.41 \%$ & $39.07 \%$ & $59.03 \%$ & $51.63 \%$ \\
\hline Insect Parts & $10.88 \%$ & $7.62 \%$ & $6.08 \%$ & $6.76 \%$ \\
\hline Unknowns & $0.68 \%$ & $1.16 \%$ & $1.40 \%$ & $1.29 \%$ \\
\hline
\end{tabular}

Percentages

\begin{tabular}{|l|r|r|r|r|}
\hline Dinocysts N Shelf & NE shelf & N shelf & NW shelf & Total \\
\hline Alisocysta sp & $0.00 \%$ & $3.85 \%$ & $0.00 \%$ & $2.27 \%$ \\
\hline Cryodinium sp & $0.00 \%$ & $0.00 \%$ & $0.00 \%$ & $0.00 \%$ \\
\hline Dinocyst spp & $0.00 \%$ & $0.00 \%$ & $0.00 \%$ & $0.00 \%$ \\
\hline Hystrichosphaeridium spp & $0.00 \%$ & $15.38 \%$ & $0.00 \%$ & $9.09 \%$ \\
\hline Impagidinium sp & $10.00 \%$ & $0.00 \%$ & $0.00 \%$ & $2.27 \%$ \\
\hline Protoperidinium sp 1 & $0.00 \%$ & $0.00 \%$ & $12.50 \%$ & $2.27 \%$ \\
\hline Protoperidinium sp 2 & $0.00 \%$ & $0.00 \%$ & $37.50 \%$ & $6.82 \%$ \\
\hline Selenopemphix antarctica & $0.00 \%$ & $0.00 \%$ & $0.00 \%$ & $0.00 \%$ \\
\hline Alterbitedinium asymmetrica & $10.00 \%$ & $15.38 \%$ & $0.00 \%$ & $11.36 \%$ \\
\hline Deflandrea spp & $0.00 \%$ & $3.85 \%$ & $12.50 \%$ & $4.55 \%$ \\
\hline Enneadocysta partridgei & $10.00 \%$ & $3.85 \%$ & $0.00 \%$ & $4.55 \%$ \\
\hline Operculum & $40.00 \%$ & $15.38 \%$ & $37.50 \%$ & $25.00 \%$ \\
\hline Spinidinium macmurdoense & $10.00 \%$ & $3.85 \%$ & $0.00 \%$ & $4.55 \%$ \\
\hline Spinidinium spp & $0.00 \%$ & $3.85 \%$ & $0.00 \%$ & $2.27 \%$ \\
\hline Turbiosphaera filosa & $20.00 \%$ & $3.85 \%$ & $0.00 \%$ & $6.82 \%$ \\
\hline Vozzhennikovia spp & $0.00 \%$ & $30.77 \%$ & $0.00 \%$ & $18.18 \%$ \\
\hline
\end{tabular}

\section{Percentages}

\begin{tabular}{|l|r|r|r|r|c|}
\hline Dinocysts & \multicolumn{1}{|c|}{ Fan } & \multicolumn{1}{|c|}{ N shelf } & Mid shelf & Coastal & Totals \\
\hline Holocene & $4.55 \%$ & $22.73 \%$ & $99.36 \%$ & $66.67 \%$ & $74.67 \%$ \\
\hline Reworked & $95.45 \%$ & $77.27 \%$ & $0.64 \%$ & $33.33 \%$ & $25.33 \%$ \\
\hline
\end{tabular}


PALYNOMORPH DISTRIBUTION TABLES 3.2c

\begin{tabular}{|c|c|c|c|c|}
\hline Total Holocene & Fan & $\mathrm{N}$ shelf & Mid shelf & Coastal \\
\hline Acritarchs & 0.10 & 0.70 & \begin{tabular}{|l|}
5.39 \\
\end{tabular} & 1.59 \\
\hline Holocene Dinocysts & 0.01 & 0.13 & 3.63 & 0.08 \\
\hline Prasinophycean Algae & 0.02 & 0.39 & 6.12 & 5.31 \\
\hline Red Algae & 0.06 & 1.08 & 7.48 & 4.23 \\
\hline Egg Cases & 0.03 & 1.10 & 6.40 & 3.01 \\
\hline Zooplankton & 0.03 & 9.08 & 55.60 & 38.79 \\
\hline Foraminifera Linings & 0.13 & 15.97 & 33.02 & 32.13 \\
\hline Insect Parts & 0.02 & 2.09 & 9.85 & 5.23 \\
\hline Unknowns & 0.01 & 0.40 & 0.82 & 1.17 \\
\hline Total Holocene & 0.41 & 30.94 & 128.31 & 91.55 \\
\hline
\end{tabular}

Grains per Gram
\begin{tabular}{|l|r|r|r|r|}
\hline Total Reworked & \multicolumn{1}{|c|}{ Fan } & N shelf & M shelf & Coastal \\
\hline Reworked Dinocysts & 0.21 & 0.44 & 0.02 & 0.04 \\
\hline Pollen & 12.92 & 13.91 & 4.13 & 1.42 \\
\hline Total Reworked & 13.13 & 14.35 & 4.15 & 1.46 \\
\hline
\end{tabular}

Grains per Gram

\begin{tabular}{|c|c|c|c|c|}
\hline Marine Palynomorphs & Fan & $\mathrm{N}$ shelf & Mid shelf & Coastal \\
\hline Acritarchs & 0.10 & 0.70 & 5.39 & 1.59 \\
\hline Holocene Dinocysts & 0.01 & 0.13 & 3.63 & 0.08 \\
\hline Prasinophycean Algae & 0.02 & 0.39 & 6.12 & 5.31 \\
\hline Red Algae & 0.06 & 1.08 & 7.48 & 4.23 \\
\hline Total & 0.19 & 2.30 & 22.63 & 11.21 \\
\hline
\end{tabular}

Grains per Gram

\begin{tabular}{|c|c|c|c|c|}
\hline Holocene Dinocysts & Fan & $\mathrm{N}$ shelf & Mid shelf & Coastal \\
\hline Alisocysta sp & 0.01 & 0.01 & 0.02 & 0.00 \\
\hline Cryodinium sp & 0.00 & 0.00 & 0.26 & 0.00 \\
\hline Dinocyst spp & 0.00 & 0.00 & 0.02 & 0.00 \\
\hline Hystrichosphaeridium spp & 0.00 & 0.05 & 0.00 & 0.00 \\
\hline Impagidinium sp & 0.00 & 0.01 & 0.00 & 0.00 \\
\hline Protoperidinium sp 1 & 0.00 & 0.01 & 0.00 & 0.00 \\
\hline Protoperidinium sp 2 & 0.00 & 0.04 & 0.77 & 0.04 \\
\hline Selenopemphix antarctica & 0.00 & 0.00 & 2.56 & 0.04 \\
\hline Total & 0.01 & 0.13 & 3.63 & 0.08 \\
\hline
\end{tabular}

Grains per Gram

\begin{tabular}{|c|c|c|c|c|}
\hline Reworked Dinocysts & Fan & $\mathrm{N}$ shelf & \begin{tabular}{|l|l} 
Mid shelf \\
\end{tabular} & Coastal \\
\hline Alterbitedinium asymmetrica & 0.03 & 0.06 & 0.00 & 0.00 \\
\hline Deflandrea spp & 0.02 & 0.03 & 0.02 & 0.00 \\
\hline Enneadocysta partridgei & 0.01 & 0.03 & 0.00 & 0.00 \\
\hline Operculum & 0.07 & 0.14 & 0.00 & 0.00 \\
\hline Spinidinium macmurdoense & 0.01 & 0.03 & 0.00 & 0.00 \\
\hline Spinidinium spp & 0.02 & 0.01 & 0.00 & 0.00 \\
\hline Turbiosphaera filosa & 0.03 & 0.04 & 0.00 & 0.04 \\
\hline Vozzhennikovia spp & 0.02 & 0.10 & 0.00 & 0.00 \\
\hline Total & 0.21 & 0.44 & 0.02 & 0.04 \\
\hline
\end{tabular}


Grains per Gram Continued

\begin{tabular}{|c|c|c|c|c|}
\hline Acritarchs & Fan & $\mathrm{N}$ shelf & Mid shelf & Coastal \\
\hline Acritarch spp 1 & 0.05 & 0.00 & 0.00 & 0.00 \\
\hline Acritarch spp 2 & 0.00 & 0.00 & 0.05 & 0.00 \\
\hline Acritarch spp 3 & 0.00 & 0.00 & 0.07 & 0.00 \\
\hline Acritarch spp 4 & 0.00 & 0.00 & 0.21 & 0.00 \\
\hline Leiospherida sp & 0.01 & 0.03 & 0.52 & 0.00 \\
\hline Leiospherida sigmopolis & 0.03 & 0.00 & 0.00 & 0.00 \\
\hline Sphaeoromorphs & 0.01 & 0.67 & 4.55 & 1.59 \\
\hline Total & 0.10 & 0.70 & 5.39 & 1.59 \\
\hline
\end{tabular}

Grains per Gram

Prasinophycean Algae

Cymatiosphaera spp 1

Cymatiosphaera spp 2

Pterospermella

Tasmanites

\begin{tabular}{|c|c|c|}
\hline 0.06 & 0.00 & 0.00 \\
\hline 0.19 & 5.96 & 5.31 \\
\hline 0.12 & 0.14 & 0.00 \\
\hline 0.01 & 0.02 & 0.00 \\
\hline
\end{tabular}

Total

Grains per Gram

\begin{tabular}{|l|l|l|l|l|}
\hline Red Algae & Fan & $\mathrm{N}$ shelf & Mid shelf & Coastal \\
\hline
\end{tabular}

\begin{tabular}{|l|r|r|r|r|}
\hline Beringiella sp & 0.06 & 1.08 & 7.48 & 4.23 \\
\hline
\end{tabular}

Grains per Gram

\begin{tabular}{|c|c|c|c|c|}
\hline Zooplankton & Fan & $\mathrm{N}$ shelf & Mid shelf & Coastal \\
\hline Tintinnid cyst & 0.00 & 0.00 & 0.77 & 0.54 \\
\hline Tintinnid loricae & 0.00 & 0.59 & 3.49 & 1.59 \\
\hline Zooplankton spp & 0.03 & 8.48 & 51.33 & 36.65 \\
\hline Total & 0.03 & 9.08 & 55.60 & 38.79 \\
\hline
\end{tabular}

Grains per Gram

\begin{tabular}{|l|l|l|l|l|}
\hline Insect parts & Fan & $\mathrm{N}$ shelf & Mid shelf & Coastal \\
\hline
\end{tabular}

\begin{tabular}{|l|r|r|r|r|}
\hline Insect parts & 0.02 & 2.09 & 9.85 & 5.23 \\
\hline
\end{tabular}

Grains per Gram

\begin{tabular}{|l|c|r|r|r|}
\hline Foraminifera linings & Fan & $\mathrm{N}$ shelf & Mid shelf & Coastal \\
\hline
\end{tabular}

\begin{tabular}{|l|r|r|r|r|}
\hline Foraminifera linings & 0.13 & 15.97 & 33.02 & 32.13 \\
\hline
\end{tabular}

Grains per Gram

\begin{tabular}{|l|r|r|r|r|}
\hline Egg cases & Fan & $\mathrm{N}$ shelf & Mid shelf & Coastal \\
\hline Egg cases & 0.03 & 1.10 & 6.40 & 3.01 \\
\hline
\end{tabular}


Grains per Gram Continued

\begin{tabular}{|l|r|r|r|r|}
\hline Unknowns & \multicolumn{1}{|c|}{ Fan } & N shelf & Mid shelf & Coastal \\
\hline Unknown sp 1 & 0.00 & 0.04 & 0.05 & 0.04 \\
\hline Unknown sp 2 & 0.00 & 0.00 & 0.16 & 0.00 \\
\hline Unknown sp 3 & 0.00 & 0.04 & 0.21 & 0.04 \\
\hline Unknown sp 4 & 0.00 & 0.01 & 0.07 & 0.08 \\
\hline Unknown sp 5 & 0.00 & 0.00 & 0.05 & 0.00 \\
\hline Unknown sp 6 & 0.01 & 0.17 & 0.26 & 0.79 \\
\hline Unknown sp 7 & 0.00 & 0.08 & 0.00 & 0.13 \\
\hline Unknown sp 8 & 0.00 & 0.03 & 0.00 & 0.04 \\
\hline Unknown sp 9 & 0.00 & 0.04 & 0.02 & 0.04 \\
\hline \multicolumn{2}{r|r|r|r|}{} \\
\hline
\end{tabular}

Grains per Gram

\begin{tabular}{|c|c|c|c|}
\hline Total Holocene N Shelf & NE shelf & $\mathrm{N}$ shelf & NW shelf \\
\hline Acritarchs & 0.15 & 0.32 & 1.29 \\
\hline Holocene Dinocysts & 0.07 & 0.16 & 0.12 \\
\hline Prasinophycean Algae & 0.52 & 0.16 & 0.55 \\
\hline Red Algae & 1.63 & 0.67 & 1.26 \\
\hline Egg Cases & 0.59 & 0.64 & 1.75 \\
\hline Zooplankton & 4.44 & 8.09 & 11.95 \\
\hline Foraminifera Linings & 2.22 & 7.52 & 29.82 \\
\hline Insect Parts & 1.18 & 1.47 & 3.07 \\
\hline Unknowns & 0.07 & 0.22 & 0.71 \\
\hline Total & 10.88 & 19.25 & 50.52 \\
\hline
\end{tabular}

Grains per Gram

\begin{tabular}{|c|c|c|c|}
\hline Dinocysts N Shelf & NE shelf & $\mathrm{N}$ shelf & NW shelf \\
\hline Alisocysta sp & 0.00 & 0.03 & 0.00 \\
\hline Cryodinium sp & 0.00 & 0.00 & 0.00 \\
\hline Dinocyst spp & 0.00 & 0.00 & 0.00 \\
\hline Hystrichosphaeridium spp & 0.00 & 0.13 & 0.00 \\
\hline Impagidinium sp & 0.07 & 0.00 & 0.00 \\
\hline Protoperidinium sp 1 & 0.00 & 0.00 & 0.03 \\
\hline Protoperidinium sp 2 & 0.00 & 0.00 & 0.09 \\
\hline Selenopemphix antarctica & 0.00 & 0.00 & 0.00 \\
\hline Alterbitedinium asymmetrica & 0.07 & 0.13 & 0.00 \\
\hline Deflandrea spp & 0.00 & 0.03 & 0.03 \\
\hline Enneadocysta partridgei & 0.07 & 0.03 & 0.00 \\
\hline Operculum & 0.30 & 0.13 & 0.09 \\
\hline Spinidinium macmurdoense & 0.07 & 0.03 & 0.00 \\
\hline Spinidinium spp & 0.00 & 0.03 & 0.00 \\
\hline Turbiosphaera filosa & 0.15 & 0.03 & 0.00 \\
\hline Vozzhennikovia spp & 0.00 & 0.25 & 0.00 \\
\hline Total & 0.74 & 0.83 & 0.25 \\
\hline
\end{tabular}

Grains per Gram

\begin{tabular}{|c|c|c|c|c|}
\hline Dinocysts & Fan & $\mathrm{N}$ shelf & Mid shelf & Coastal \\
\hline Holocene & 0.01 & 0.13 & 3.63 & 0.08 \\
\hline Reworked & 0.21 & 0.44 & 0.02 & 0.04 \\
\hline Total & 0.22 & 0.57 & 3.66 & 0.13 \\
\hline
\end{tabular}




\section{APPENDIX B}

\section{Sediment description taken from raw samples before processing}

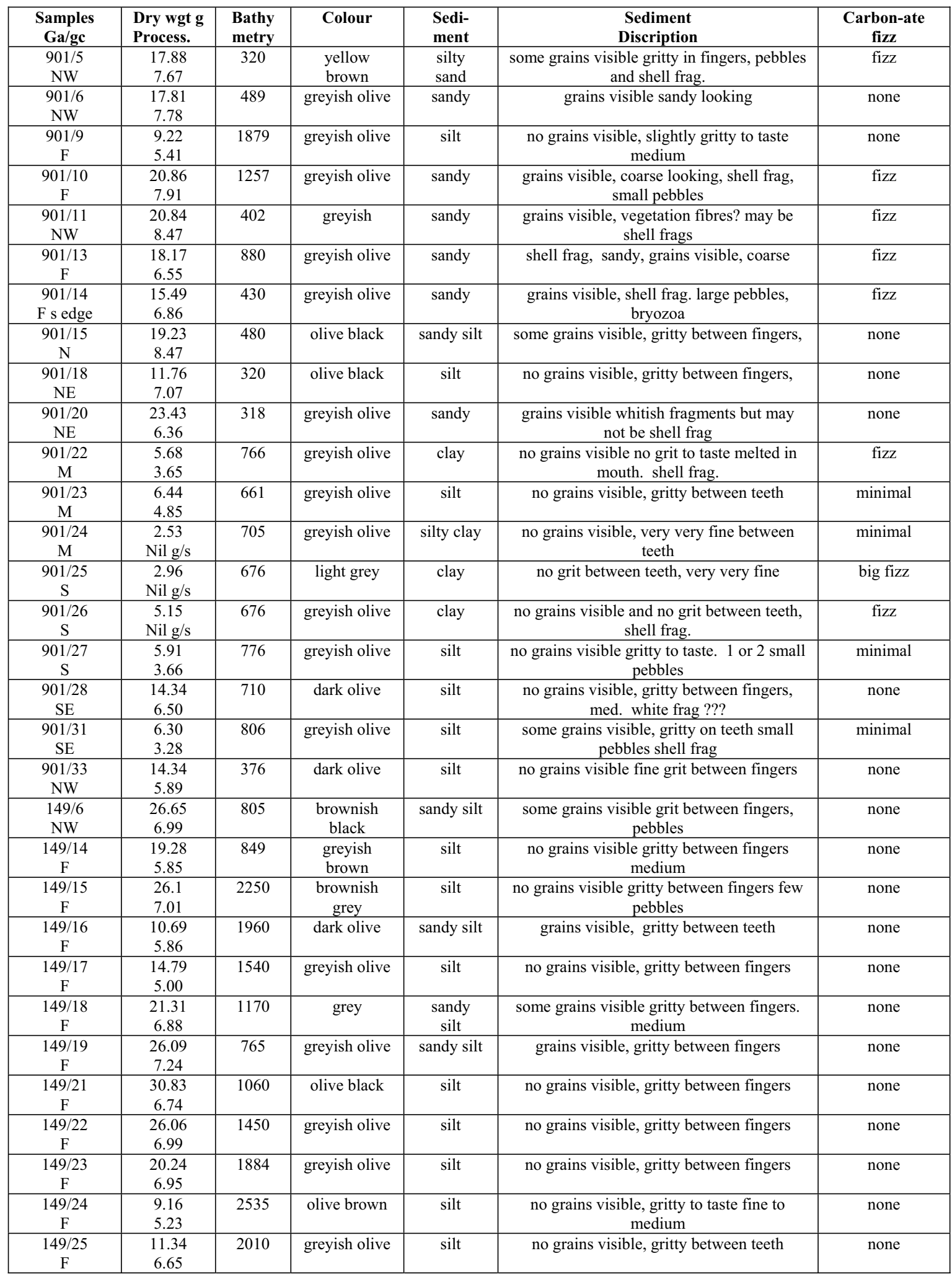




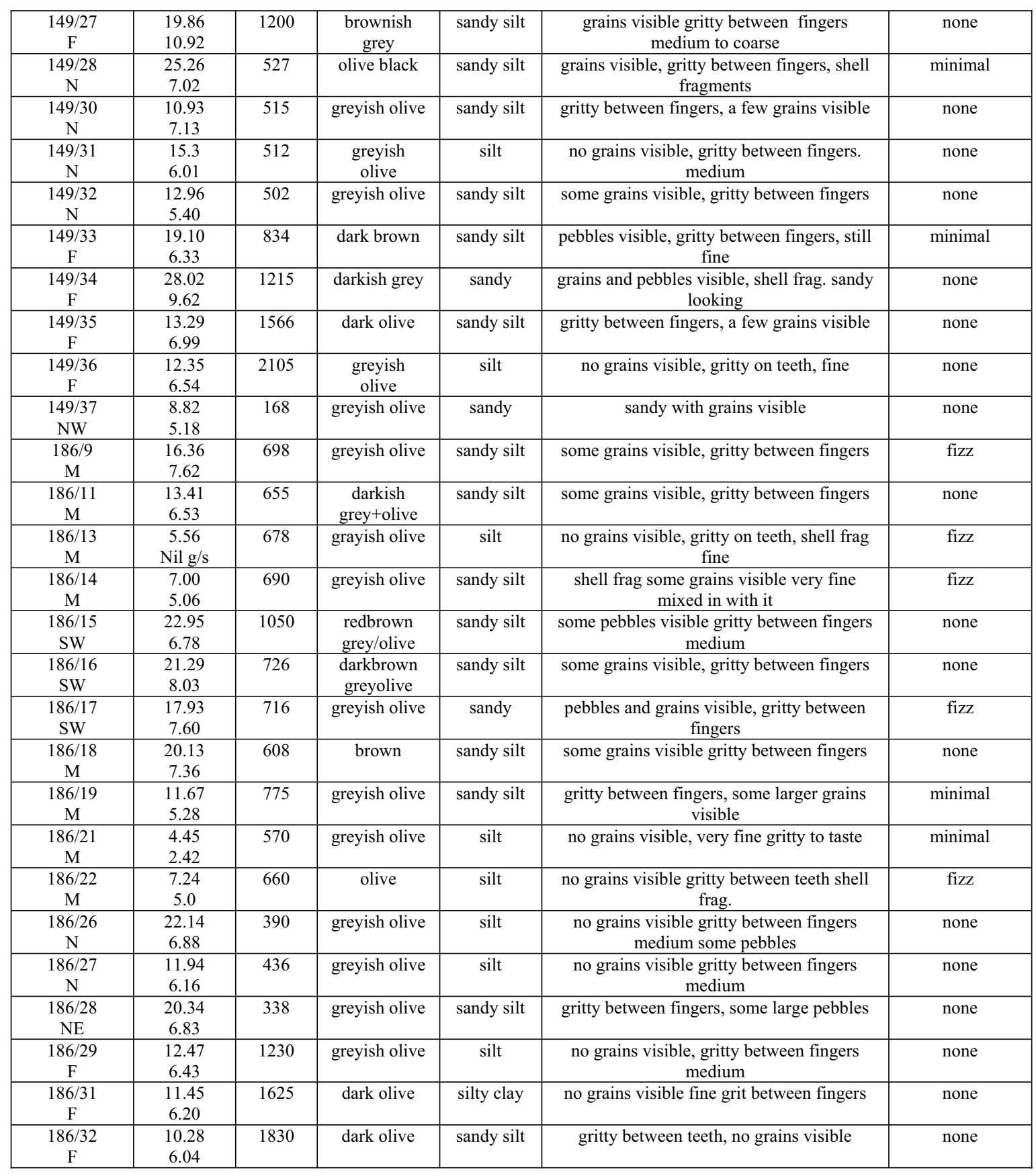




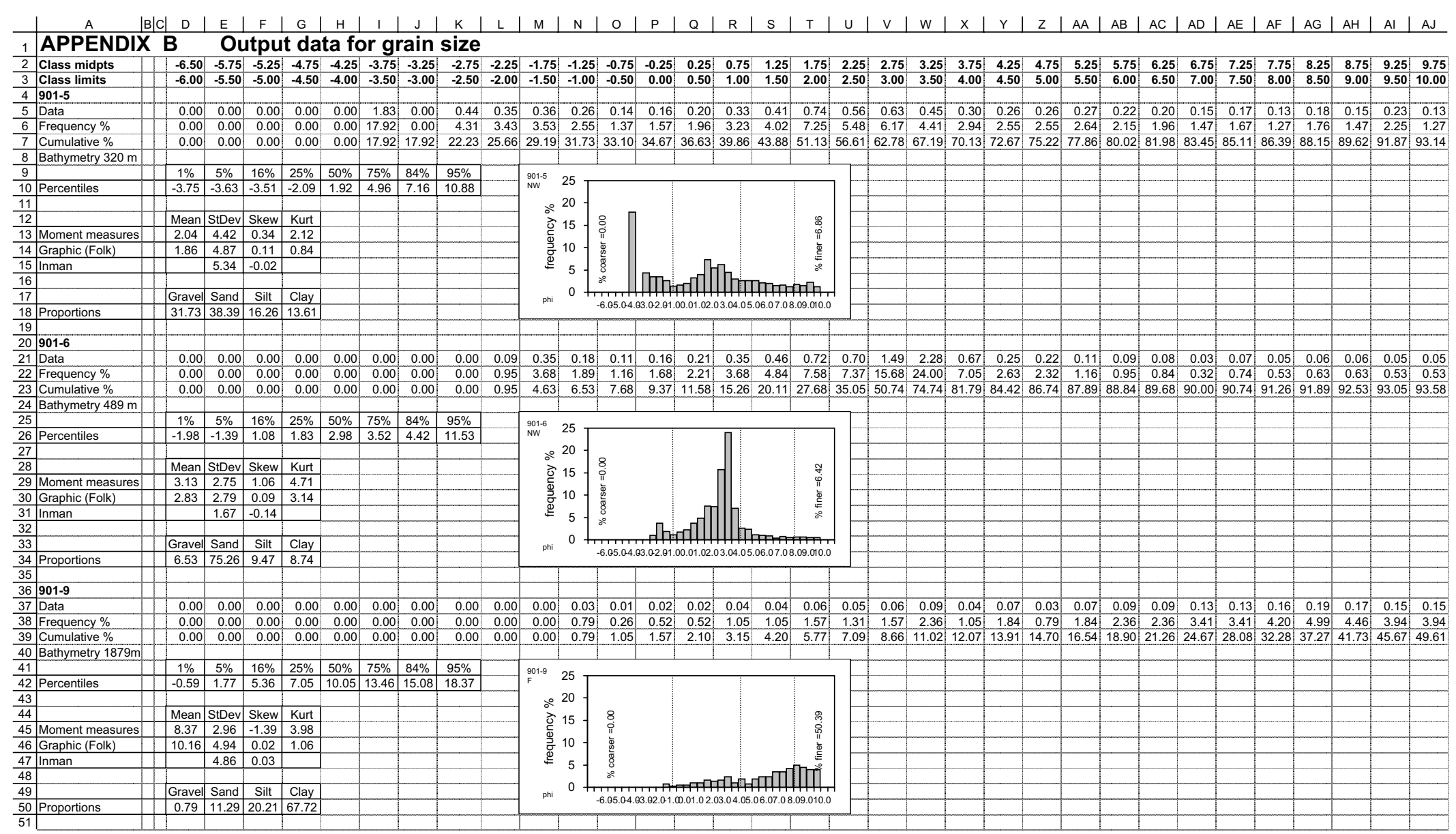




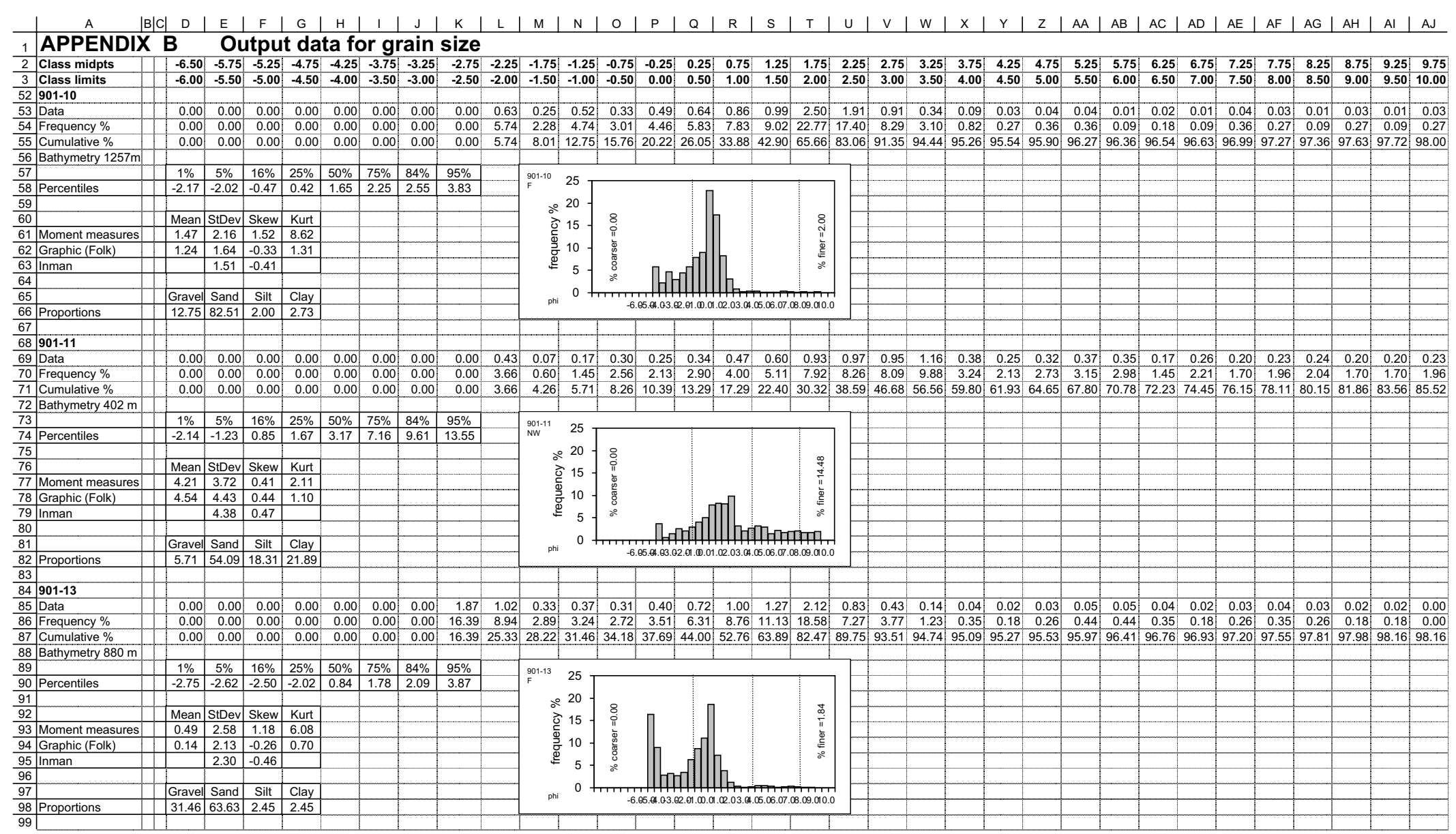




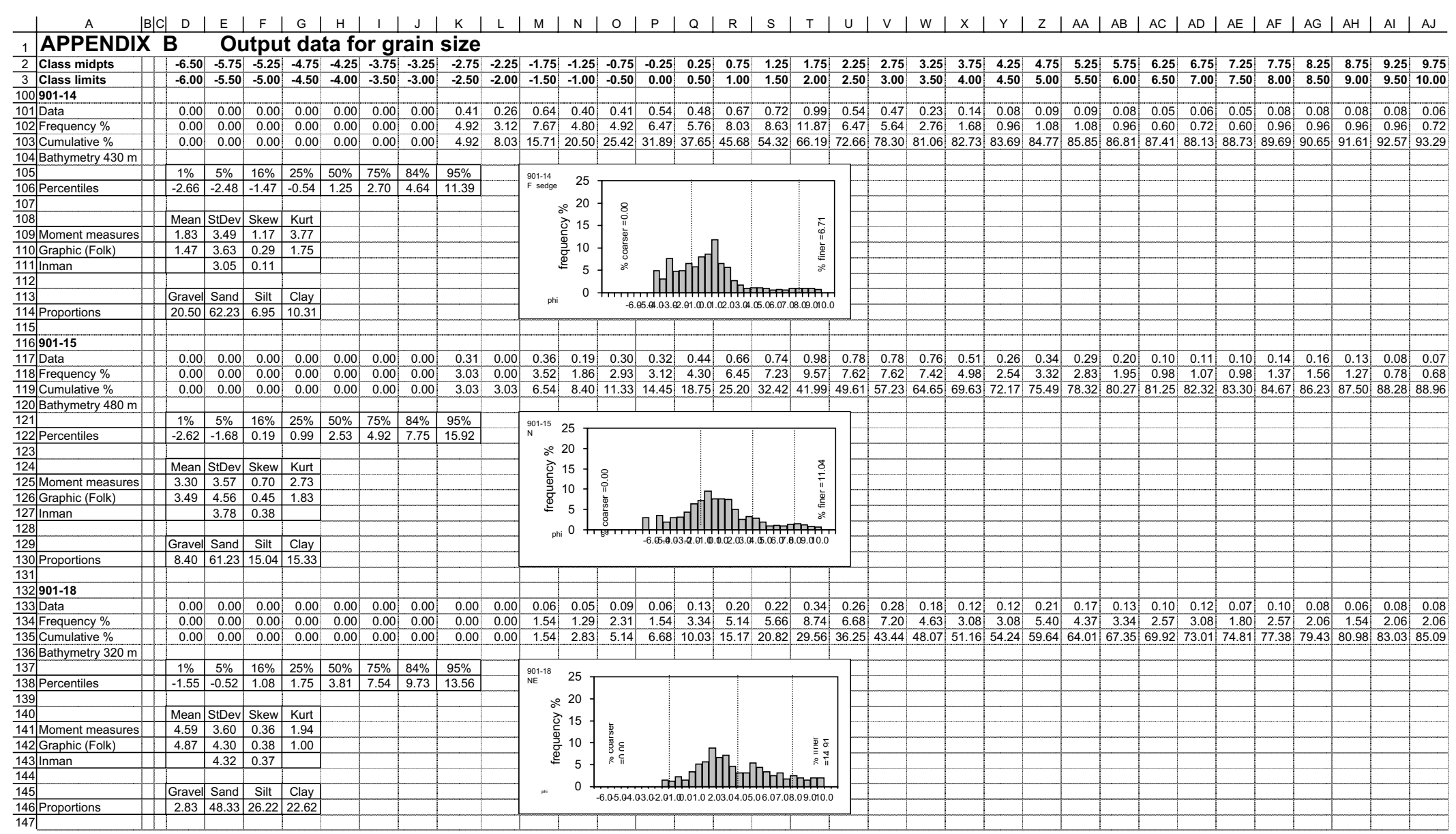




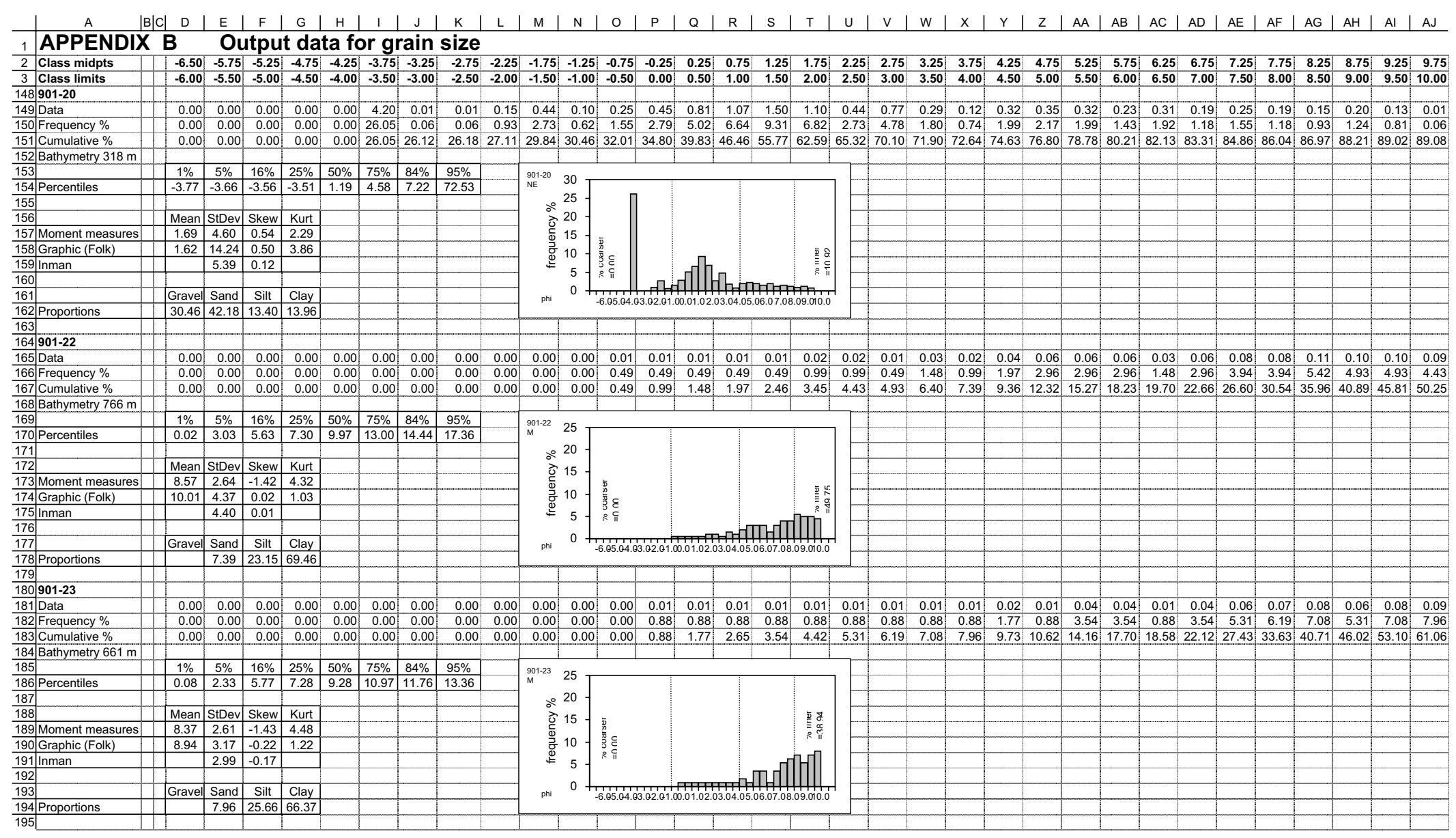




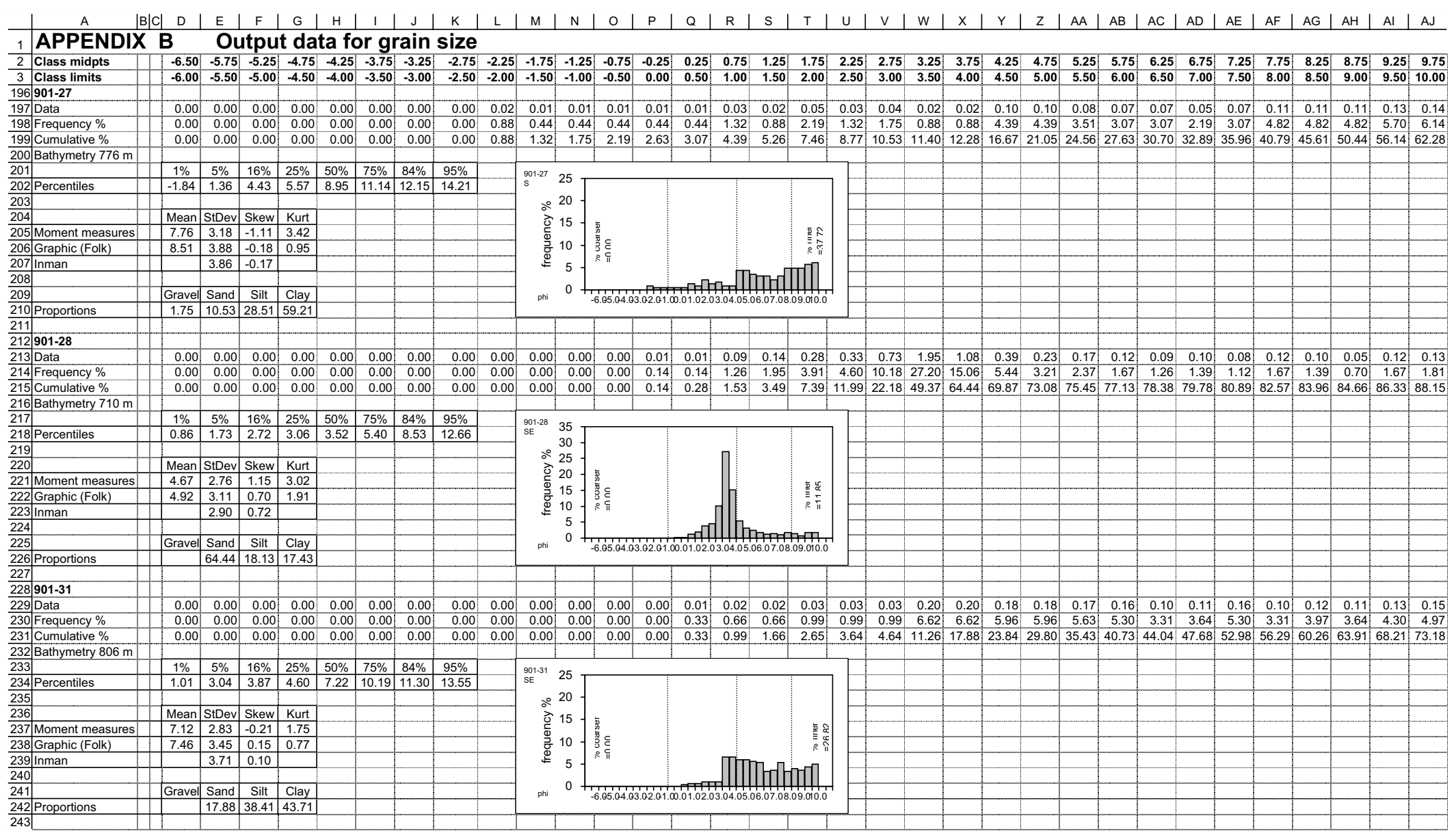




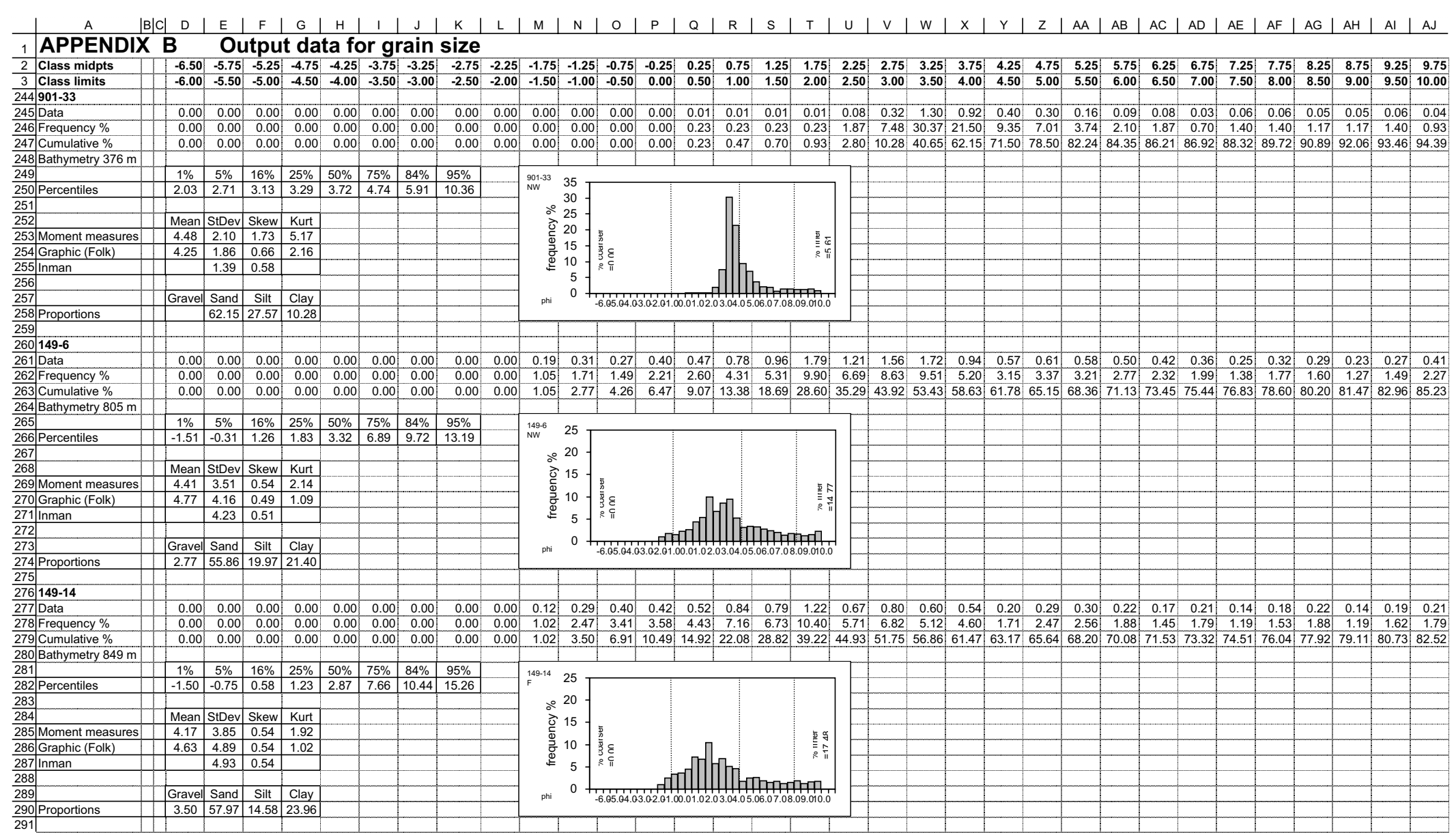




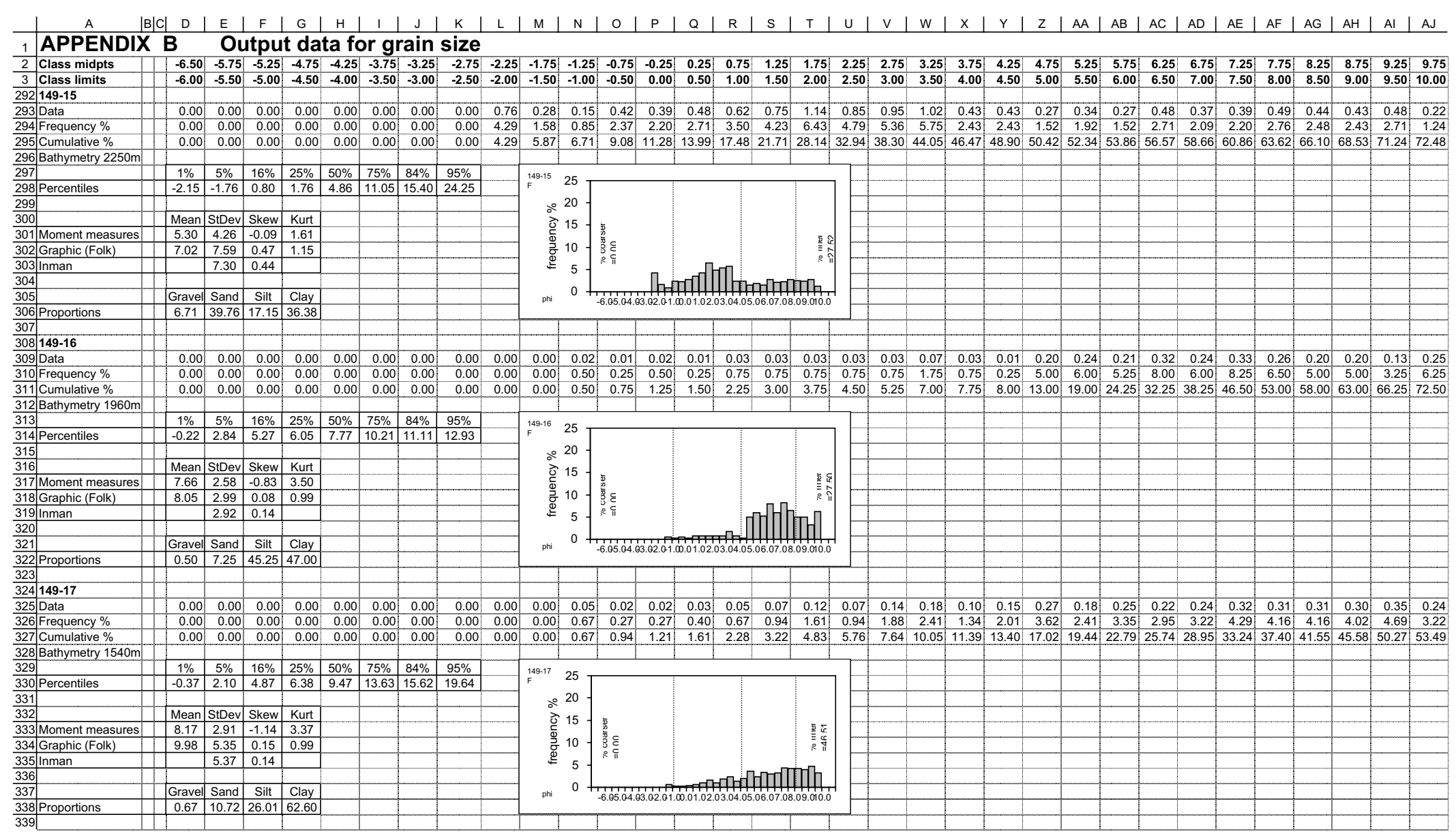




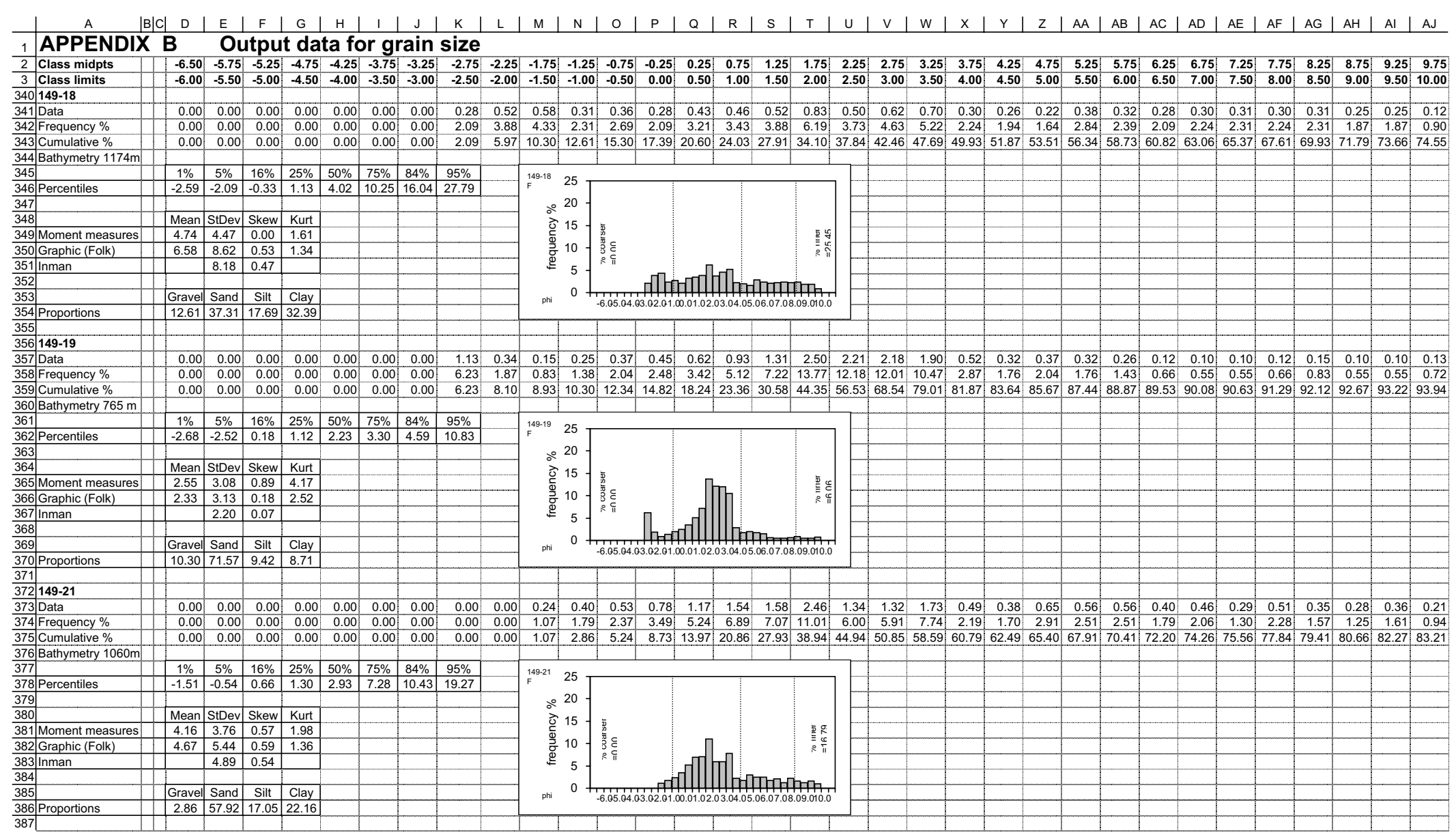




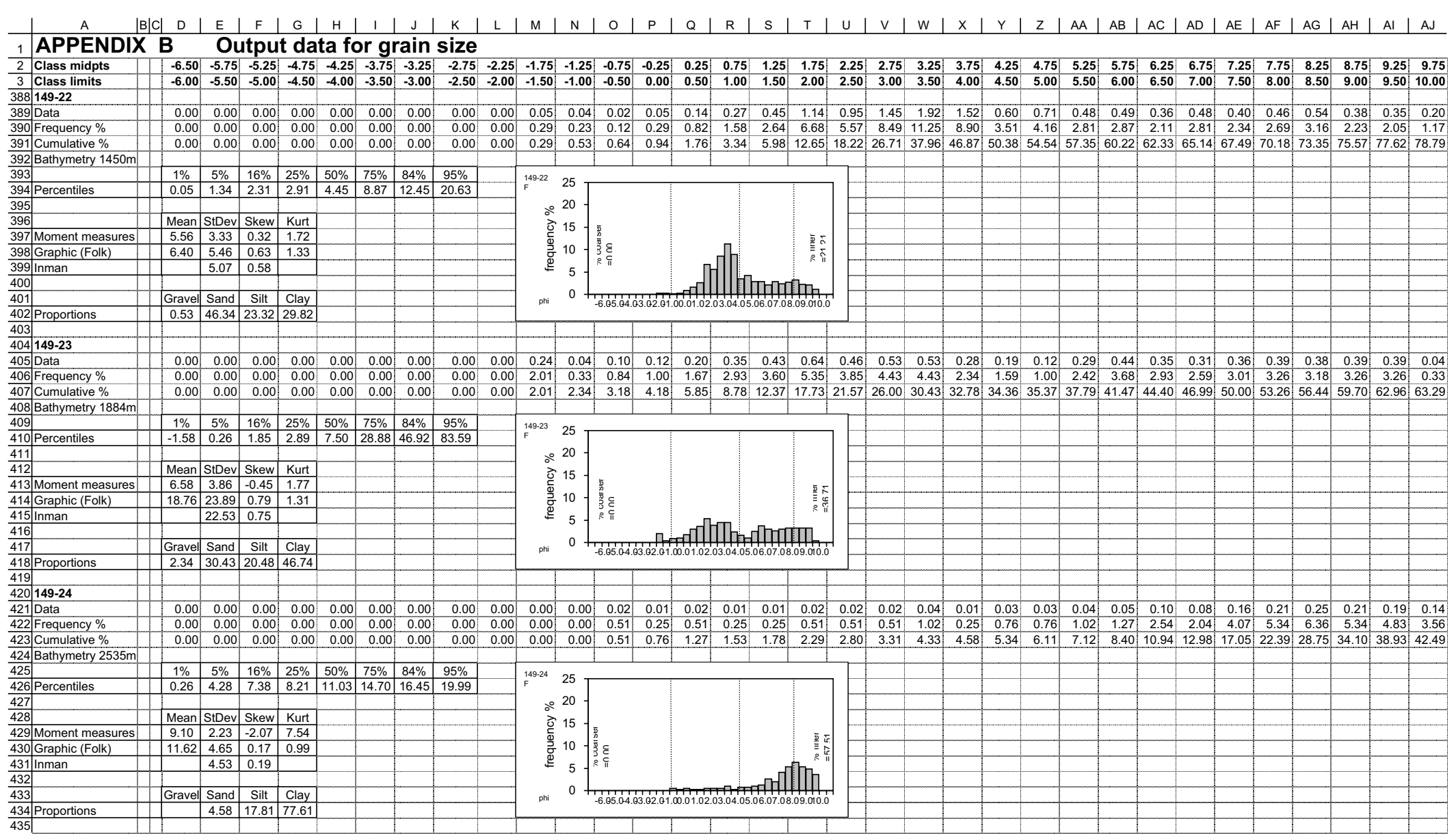




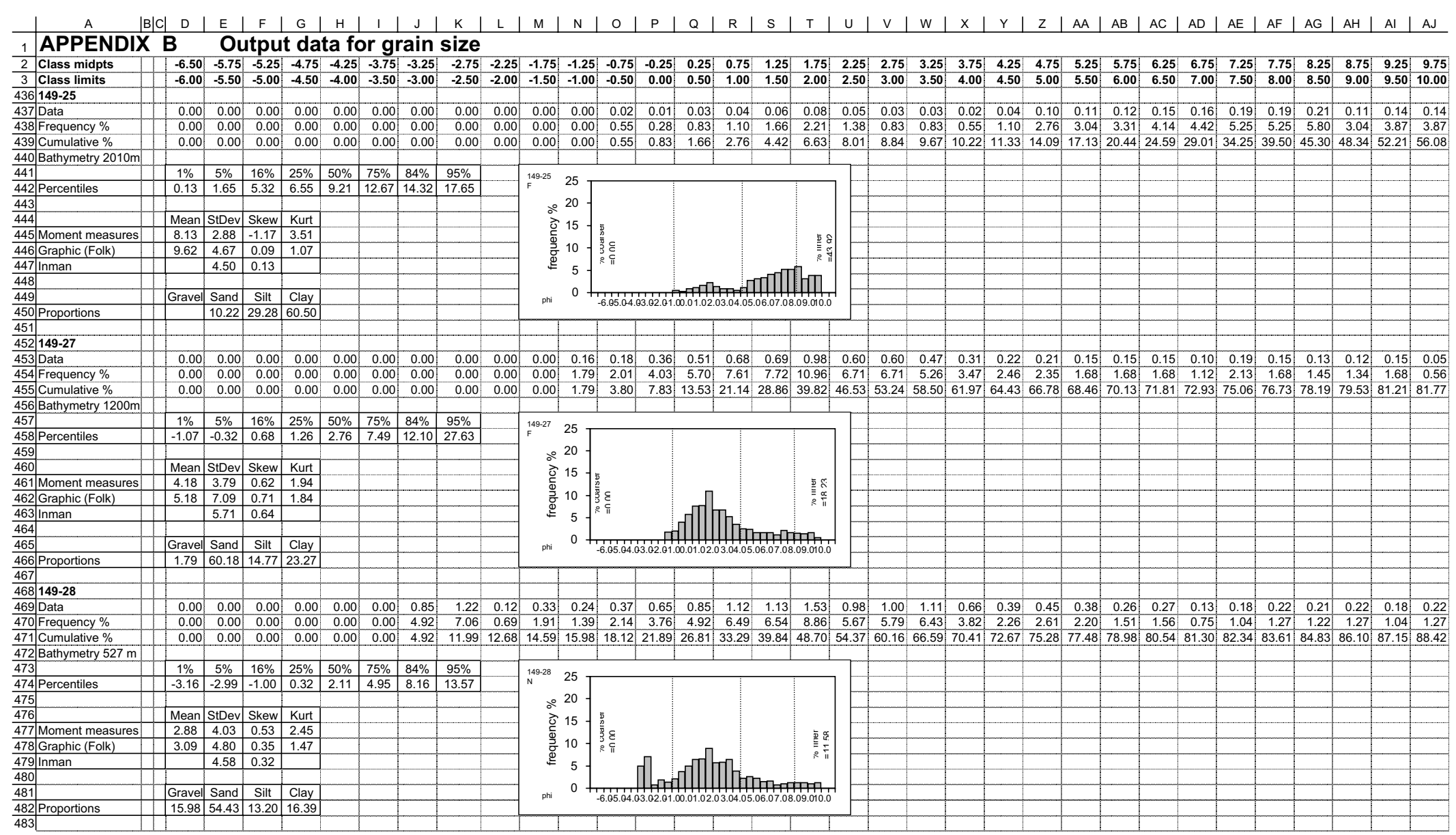




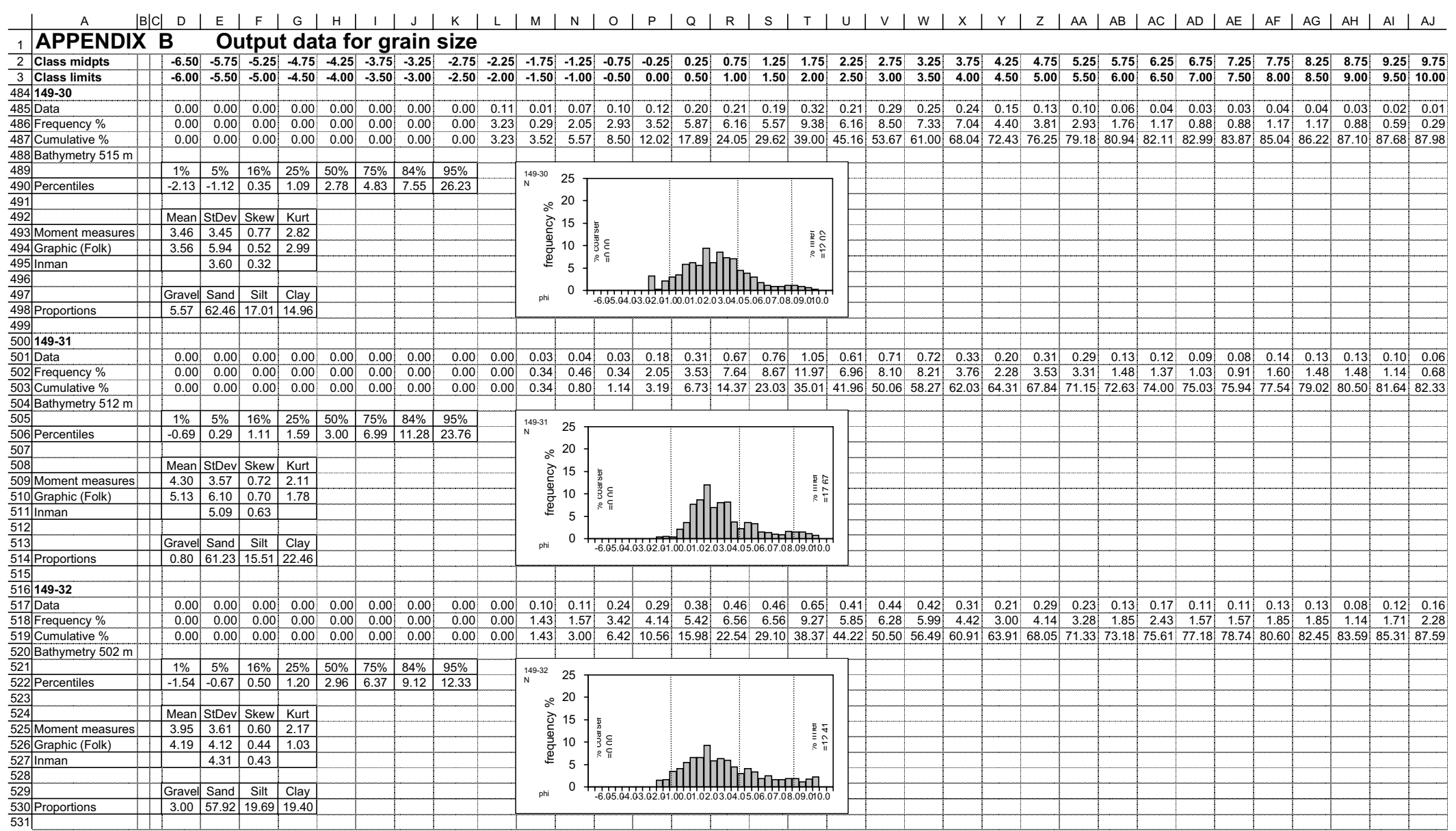




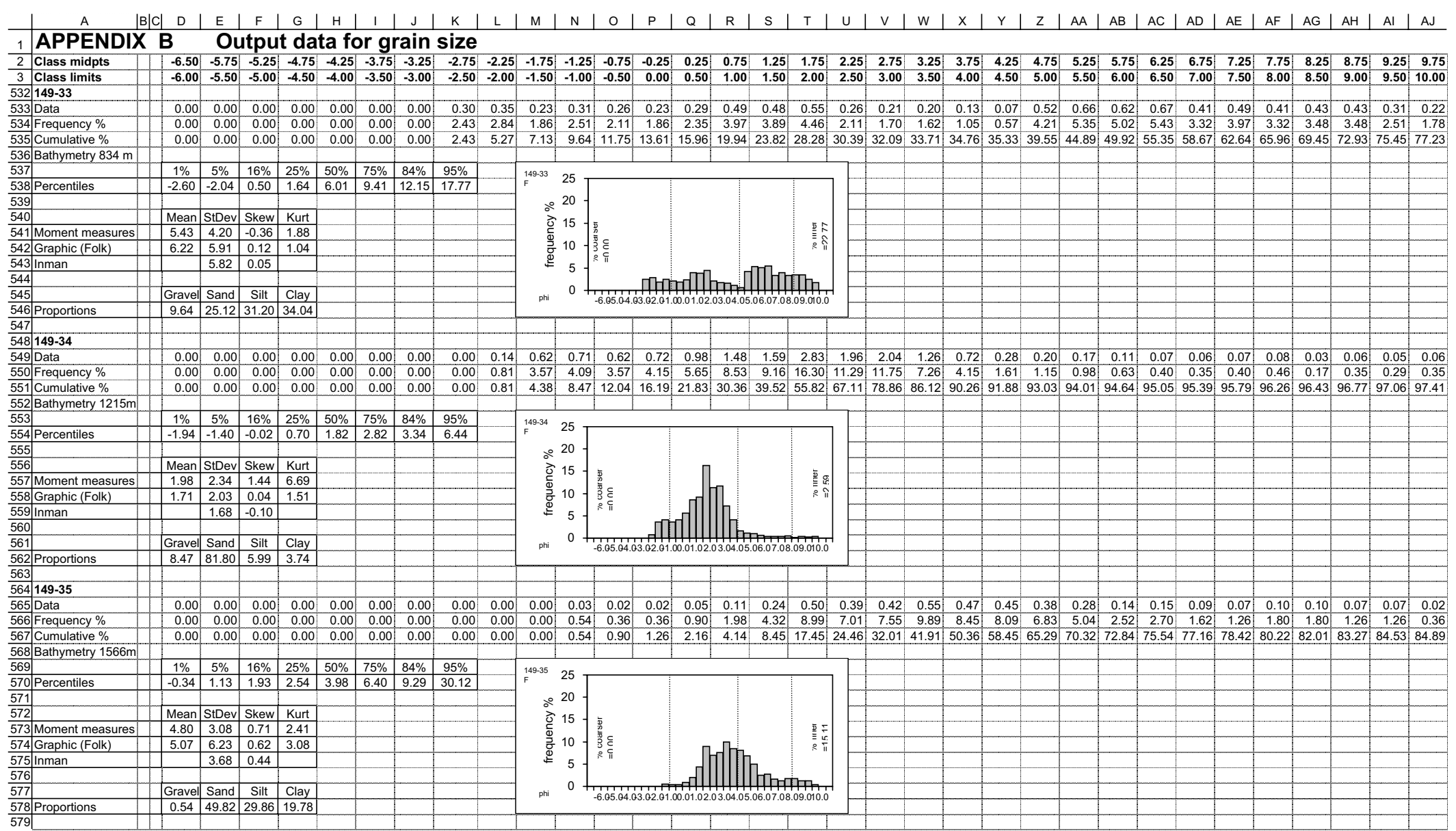




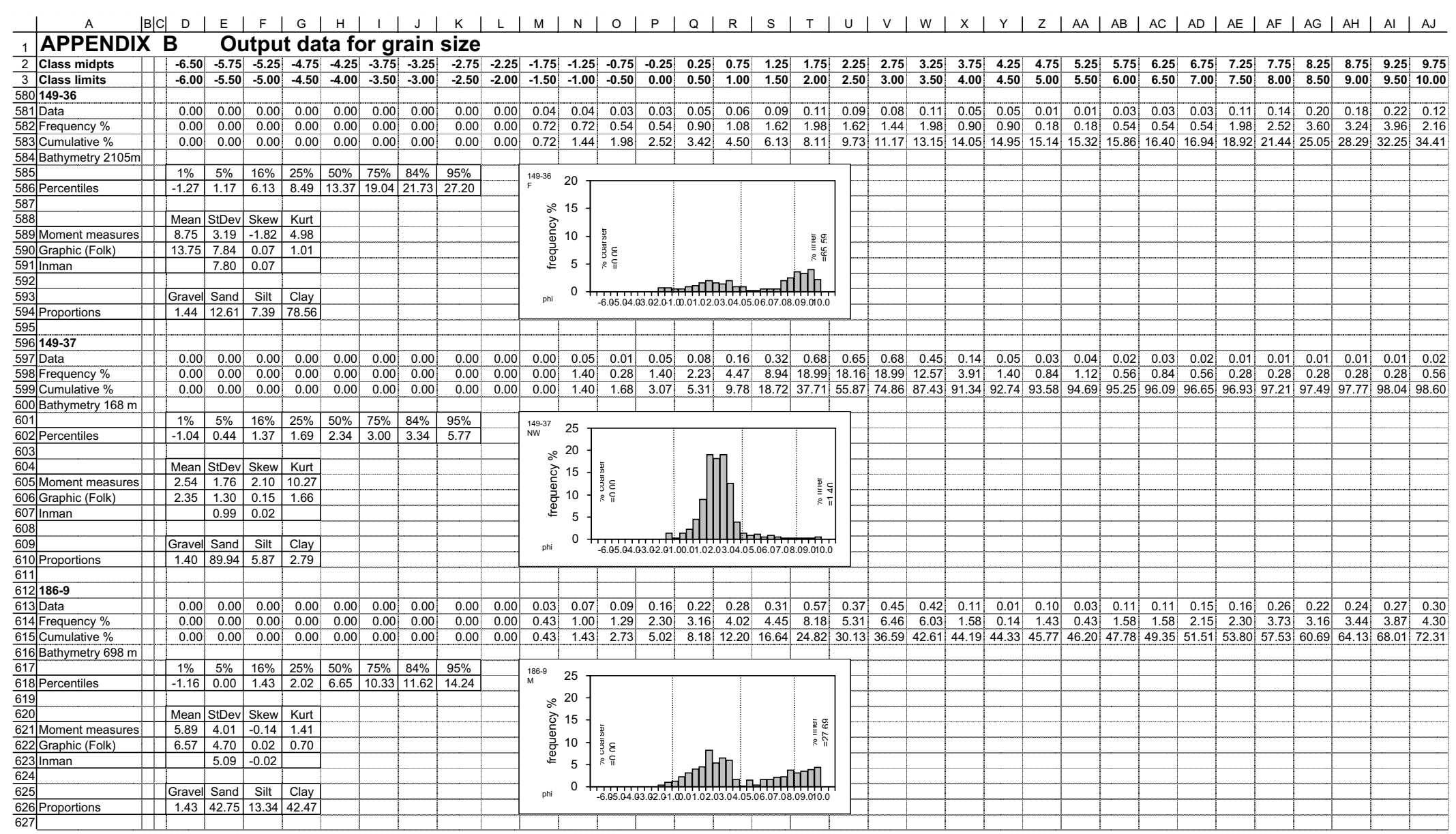




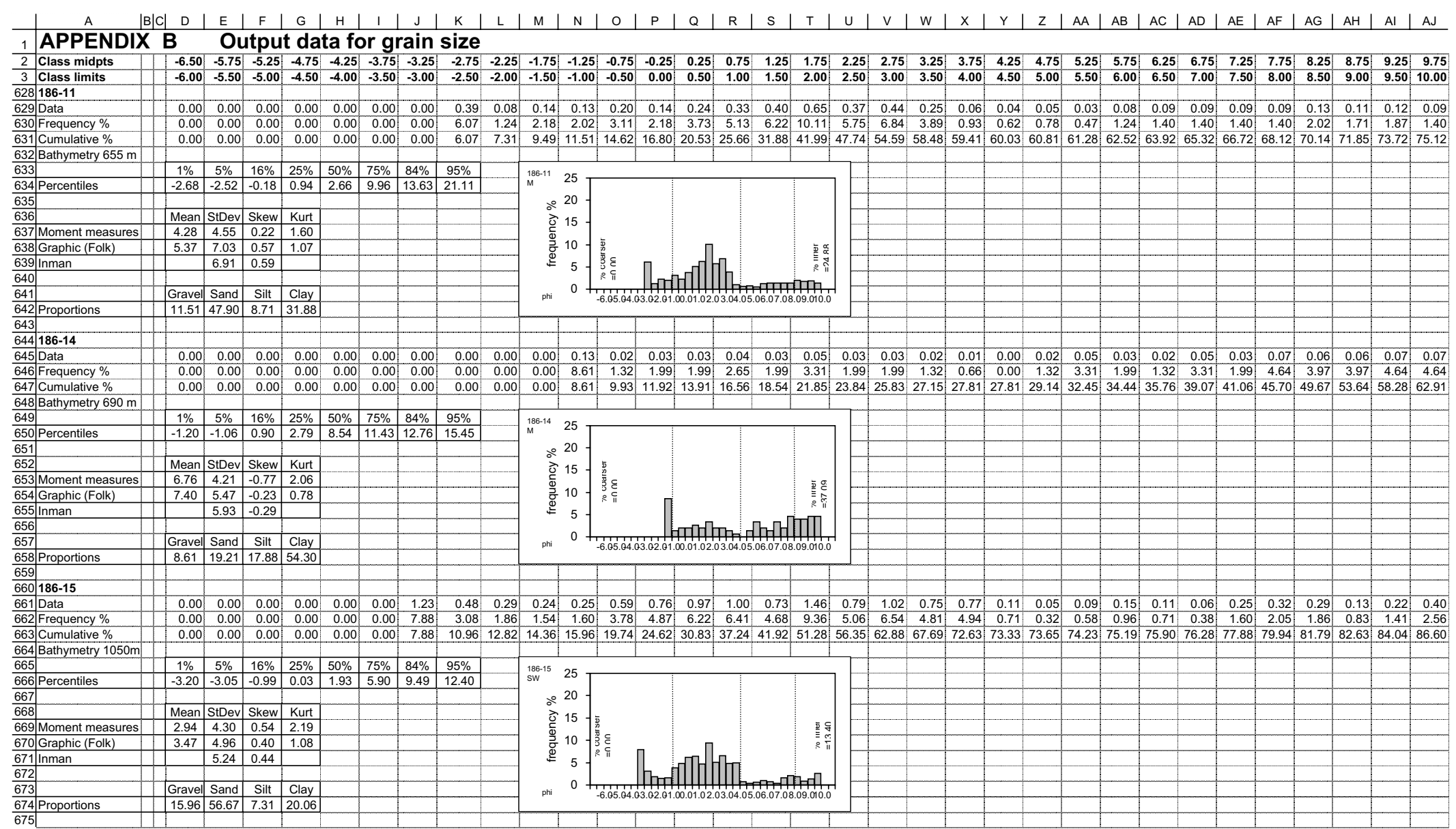




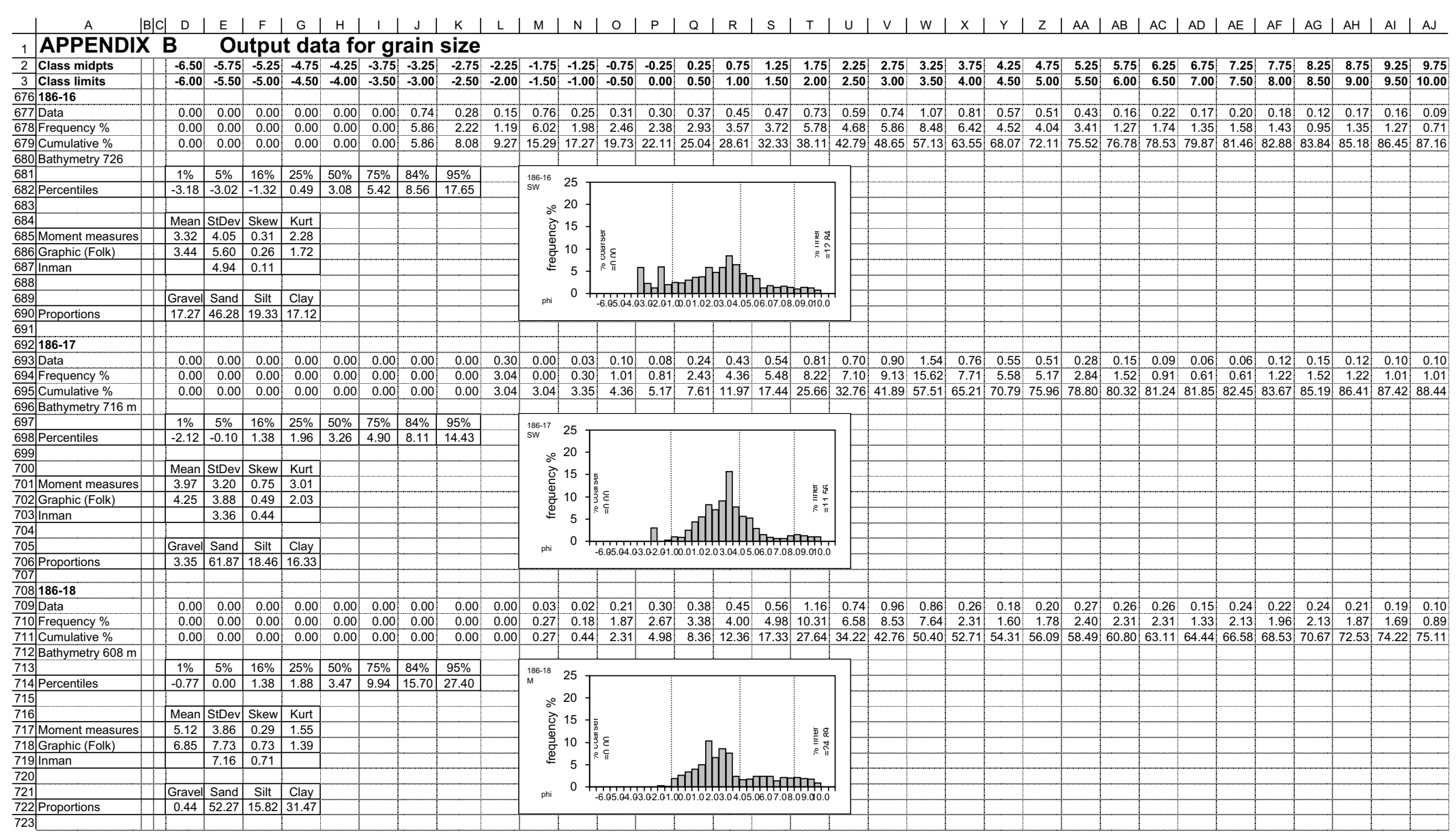




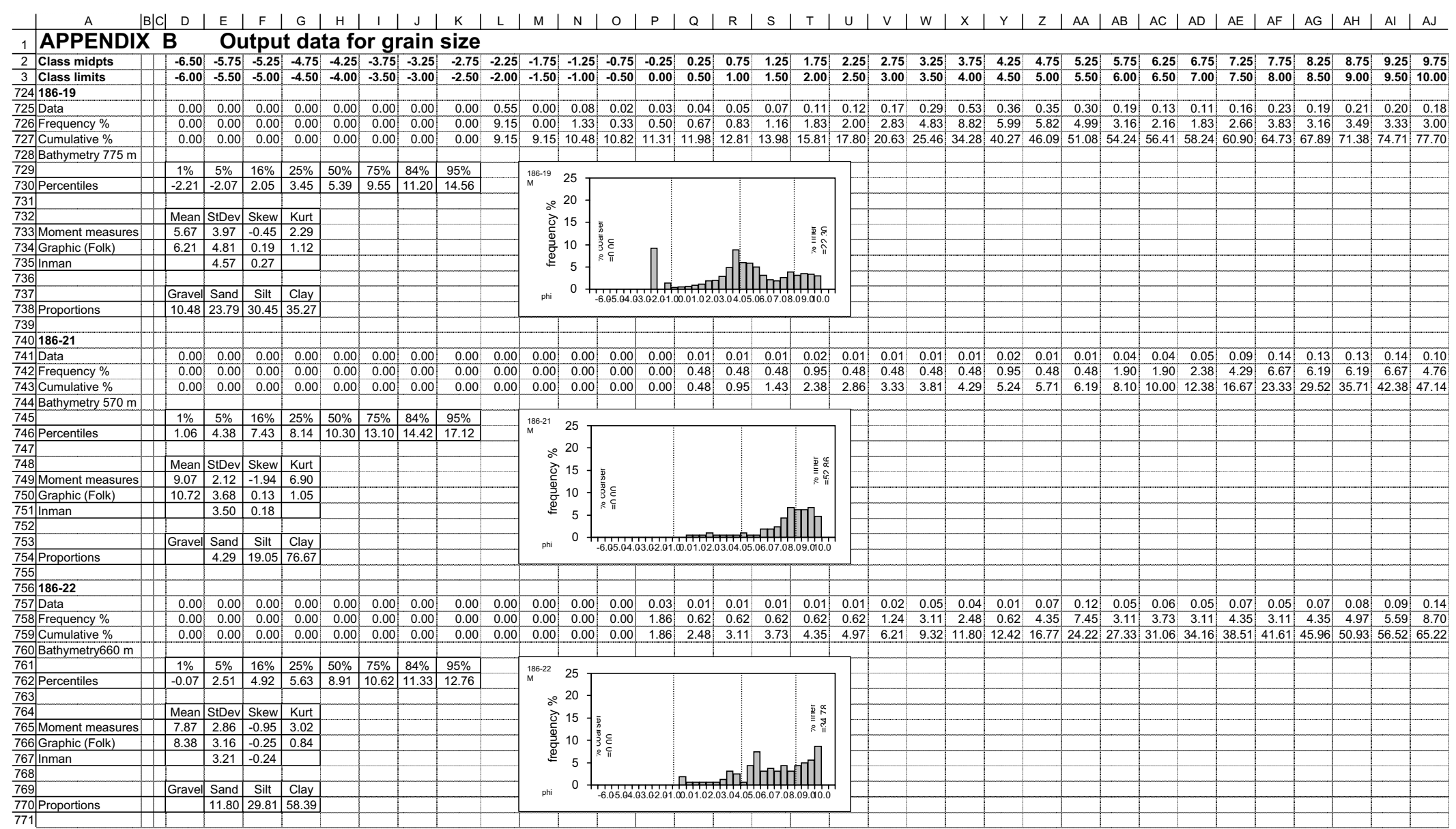




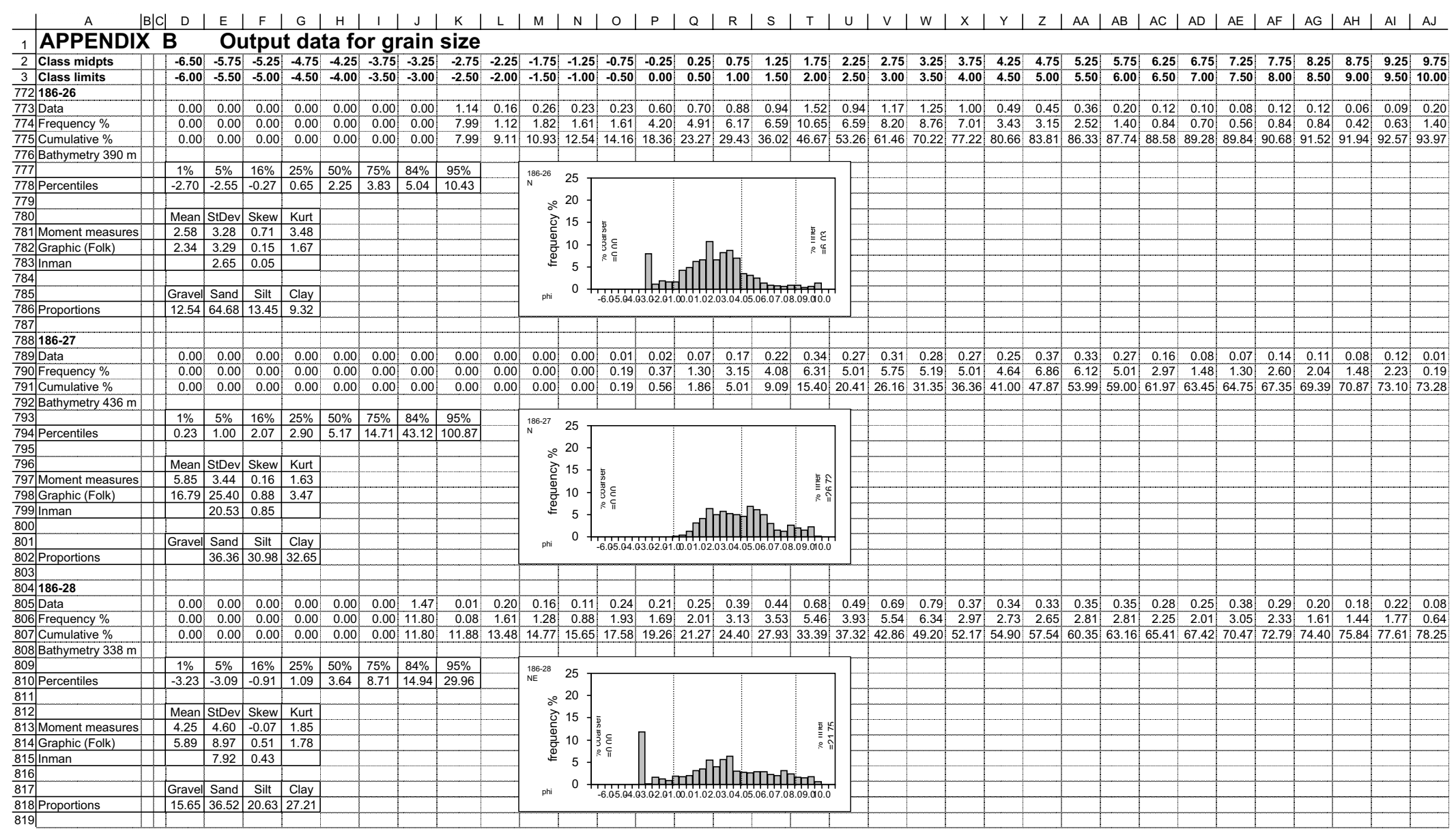




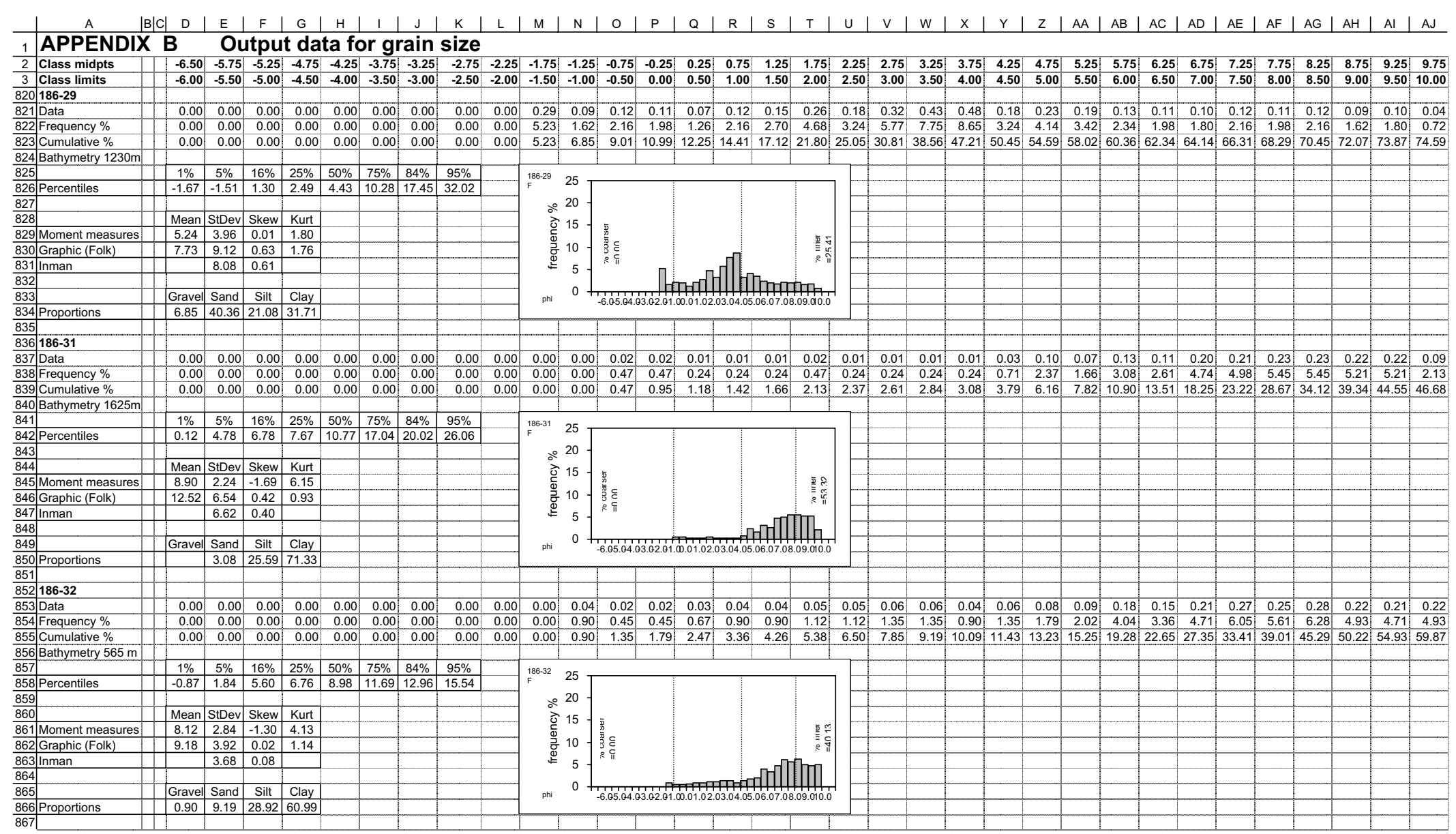




\title{
APPENDIX C
}

\section{List of Species}

\author{
Informal Group ACRITARCHA Evitt (1963), Downie et al (1963) \\ Subgroup ACANTHOMORPHITAE Downie, Evitt and Sargent (1963) \\ Acritarch sp. 1 \\ Plate 1 Figure 1-3
}

Acanthomorphitae: Spherical with no inner body, processes are simple have regular symmetry, and are homomorphic. No obvious opening. Size $125 \mu \mathrm{m}$. Size of processes $25 \mu \mathrm{m}$.

\section{Acritarch sp. 2}

Plate 1 Figure 4-7

Acanthomorphitae: Ovoid with no inner body, processes are simple, acuminate, pelatoid and cylindrical, have regular symmetry and are heteromorphic. No obvious opening. Size $75 \mu \mathrm{m}$. Second type size 95.

\section{Acritarch sp. 3}

Plate 1 Figure 8-10

Acanthomorphitae: Spherical and dorso-ventrally compressed; processes are simple, have regular symmetry and are homomorphic. No obvious opening. Size 120-125 $\mu \mathrm{m}$.

\section{Acritarch sp. 4}

Plate 1 Figure 11-12, Plate 2 Figure1-4

Acanthomorphitae: Spherical with no inner body; processes are simple, acuminate, and cylindrical, have regular symmetry and are heteromorphic. Opening visible. Size $100-150 \mu \mathrm{m}$.

\section{Order PYRAMIMONADALES Chadefaud 1950}

Family Leiosphaeridiaceae Timofeev 1956

Form genus Leiosphaeridia Eisenack 1958

Leiospherida sp.

Plate 2 Figure 5 
2000 Leiosphaeridia sp.2 Hannah et al Figure 4d

Spherical and pale yellow in colour, wall is smooth unornamented $\sim 1 \mu \mathrm{m}$ thick. No visible opening; size $\sim 35 \mu \mathrm{m}$.

\section{Subgroup uncertain \\ Genus Sigmopollis Hedlund 1965, Tappan 1980 \\ Sigmopollis sp. Hannah et al 1998}

1998 Sigmopollis sp. Hannah et al Figure 4g

2000 Sigmopollis sp. Hannah et al Figure 4c

Subspherical to ovoid and sigmoidal, wall is smooth unornomented, hyaline and colourless; size $55 \mu \mathrm{m}$.

\section{Subgroup SPHAEROMORPHITAE Downie, Evitt \& Sarjeant 1963}

\section{Sphaeromorph sp.}

\section{Plate 2 Figure 6-12}

Spherical to ovoid no inner body; wall is usually smooth and easily folded, unornamented with no visible opening. Size $60-200+\mu \mathrm{m}$.

\section{Division PYRRHOPHYTA Pascher, 1914 \\ Class DINOPHYCEAE Fritsch, 1929 \\ Order GONYAULACALES Taylor, 1980 \\ Family Goniodomaceae Lindemann, 1928 \\ Alisocysta sp. Stover \& Evitt 1978 \\ Plate 3 Figure 1-3}

1980 Alisocysta sp. Tappan Figure 4.124

2000 Alisocysta sp. Levy \& Harwood Plate 1, Figures a-d

Ovoid with penitabular septa with an apical archeopyles, pale brown colour size 75 $\mu \mathrm{m}$.

\section{Genus Impagidinium Stover and Evitt 1978}

\section{Impagidinium sp.}

\section{Plate 4 Figures 6-9}

Subspherical light brown in colour, wall smooth, paratabulation, singulum visible; Size $60 \mu \mathrm{m}$. 
Genus Hystrichosphaeridium Deflandre 1937b, Davis and Williams 1966

Plate 4 Figures 4-5

1980 Hystrichosphaeridium Wilson and Close page 56

2000 Hystrichosphaeridium Levy \& Harwood, Plate 6, h-j

Spherical, processes vary in length but chorate. Size $50-75 \mu \mathrm{m}$.

Order PERIDINIALES Haekel, 1894

Family Protoperidiniaceae Bujak and Davies, 1998

Genus Cryodinium Esper and Zonneveld 2002

Cryodinium sp.

Plate 3 Figure 4-12

2002 Cryodinium meridianum sp. Esper and Zonneveld Figure 4-9

Spherical and dark brown in colour, paratabulation with intercalary archeopyles size $35-50 \mu \mathrm{m}$.

Genus Protoperidium Bergh, 1881 emend. Balech, 1974

Protoperidiniod sp. 1

Plate 5 Figure 5-9

Spherical to ovoid with Suessioid tabulation type, pale yellow in colour and no processes; possible cingulum in the form of smaller latitudinal plate arrangements size $115 \mu \mathrm{m}$.

Genus Protoperidium Bergh, 1881 emend. Balech, 1974

Protoperidiniod sp. 2

Plate 4 Figure 10-12

1998 Dinocyst sp. Wrenn et al Figure 5a,b

Sub-spheroidal to ovoid in shape with a prominent cingulum and sulcus. Wall is dark brown and granular with no tabulation or processes present; size $75 \mu \mathrm{m}$.

Genus Selenopemphix Benedek, 1972 emend. Head, 1993

Selenopemphix antarctica Marret and de Vernal, 1997

Plate 5 Figures 1-4

1997 Selenopemphix antarctica Marret, and de Vernal Plate V Figures 1-5 
1998 Selenopemphix antarctica Harland et al Plate 2 Figures 10-12

Spherical with two antapical horns, apically and antapically compressed, slightly pinkish in colour with granulations on the surface. Size $60-75 \mu \mathrm{m}$

\section{Dinocyst sp.}

\section{Plate 4 Figure 1-3}

Dinocyst sp: Ovoid with apical archeopyle and processes chorate, size $60 \mu \mathrm{m}$.

\section{Reworked Dinocysts}

Genus Alterbidinium Lentin \& Williams 1985; emend. Khowaja-Ateequzzaman and Jain 1991

Alterbidinium asymmetricum Wilson, 1967 comb. Nov.

Plate 10 Figure 3, Figure 7-9

Ovoid, hyaline bi-layered, dorso-ventrally flattened, angular, bi-laterally asymmetric, smooth walls. Long apical horn, smaller antapical horns, cingulum, intercalary archeopyle. Size $80 \mu \mathrm{m}$.

\section{Genus Deflandrea Eisenack 1938; emend. Williams and Downie 1966; \\ Deflandrea sp.}

\section{Plate 10 Figure 1-2}

Spherical inner body, thick walled smooth, dorso-ventrally flattened, outer layer forms pointed apical horn and two antapical horns. Intercalary archeopyle. Size 70 $\mu \mathrm{m}$.

\section{Family Gonyaulacaceae Lindemann, 1928}

\section{Genus Enneadocysta partridgei Stover \& Williams 1995}

Spherical, chorate processes splayed out at the end. Size $75 \mu \mathrm{m}$.

\section{Genus Spinidinium Cookson \& Eisenack, 1962; Lentin \& Williams 1976}

\section{Spinodinium sp.}

Sub spherical showing short spines with long apical horn. Species broken. Size $\sim 75$ $\mu \mathrm{m}$. 
Spinidinium macmurdoense (Wilson 1967) Lentin \& Williams, 1976

2000 Spinidinium macmurdoense Levy \& Harwood Plate 9, Figure c,d

Sub spherical with smooth hyaline inner body, dorso-ventrally flattened, angular

bilaterally asymmetric. Outer covering has small spines. Long apical horn shorter antapical horn. Size $75 \mu \mathrm{m}$.

Genus Turbiosphaera Archangelsky, 1969a

Turbiosphaera filosa (Wilson, 1967) Archangelsky 1969a

Plate 9 Figures 10-12

1999 Turbiosphaera filosa CRP Science Team Figure 5.8i p129

2000 Turbiosphaera filosa Levy \& Harwood Plate 10 d-i

Spherical dark brown inner body, cingulum visible, outer membrane appearance granular and extends out over inner body unevenly. Size $50 \mu \mathrm{m}$.

\title{
Genus Vozzhennikovia sp.
}

Sub-spherical to spherical with long apical horn most are broken up but have slightly longer spines covering. Size $\sim 50 \mu \mathrm{m}$.

\section{Operculae}

Most unknown some may be from Enneadocysta partridgei. All are operculae with processes.

\author{
Division PRASINOPHYTA Round 1971 \\ Order PTEROSPERMATALES Schiller 1925 \\ Family Cymatiosphaeraceae Mädler 1963
}

Genus Cymatiosphaera O.Wetzel, 1933 ex Deflandre, 1954

Cymatiosphaera sp. 1

Plate 5 Figure 10-12

1998 Cymatiosphaera sp. Hannah et al Figure 3d

2000 Cymatiosphaera sp. 1 Hannah et al Figure 3c,d 
Spherical central body, wall smooth colourless to pale yellow $\sim 1 \mu \mathrm{m}$. hyaline, fine membrane anastomoses over surface, processes visible. No opening visible. Size 15 $-20 \mu \mathrm{m}$.

\section{Cymatiosphaera sp. 2}

\section{Plate 6 Figure 1-10}

Spherical central body, wall smooth, membrane like netting anastomoses over surface, no visible opening, membrane gathered at edges. Size $75-115 \mu \mathrm{m}$.

\section{Family Pterospermellaceae Eisenack 1972}

\section{Genus Pterospermella Eisenack}

\section{Pterospermella sp.}

\section{Plate 6 Figure 11-12}

1998 Pterospermella sp. Hannah et al Figure 3i

2000 Pterospermella sp. Hannah et al Figure 3g

Large flotation membrane colourless, borders a spherical compressed central body yellow-brown in colour. No aperture visible. Size 75-90 $\mu \mathrm{m}$.

\section{Family Tasmanitaceae Sommer 1956}

\section{Genus Tasmanites Newton 1875}

\section{Tasmanites sp.}

\section{Plate 7 Figure 1-3}

1980 Tasmanites sp. Tappan Figure 10.10

1999 Tasmanites sp. CRP Science Team Figure 5.9g

Spherical central body, double layered wall with perforations of radially arranged pores of two distinct sizes. Size $105-125 \mu \mathrm{m}$.

\section{Class RHODOPHYCEAE \\ SubClass FLORIDEOPHYCIDAE \\ Order CERAMIALES \\ Family Rhodomelaceae \\ Genus Beringiella Bujak 1984 \\ Beringiella sp.}




\section{Plate 7 Figure 4-11}

1984 Beringiella Mudie 1992 Plate 2 Figure 17

1996 Beringiella Mudie and Harland Plate 2 Figure 15

Ovoid central body, smooth walls with edge $\sim 1 \mu \mathrm{m}$, brown with apical archeopyle with serrated edges. Size 50-60 $\mu \mathrm{m}$.

\section{Order TINTINNIDA}

Family Favellidae Kofoid and Campbell, 1929

\section{Genus unknown}

Plate 8 Figure 5-6

Large various shapes bell, to conical, aperture at oral end closed aboral end rounded or pointed form. Hyaline to brown in colour. Size $100-300+\mu \mathrm{m}$.

\section{Tintinnid cyst}

Plate 8 Figure 3-4

Ovoid shape jug like type, tin walled light brown, aperture round. Size100-125 $\mu \mathrm{m}$.

\section{UNKNOWN SPECIES}

Zooplankton sp.

Plate 8 Figure 7-12, Plate 9 Figure 1-9

Spherical two layered, inner body thick walled brown no ornamentation, round aperture. Outer layer thin hyaline with "tail" attached, easily folds. Size 125 - 175 $\mu \mathrm{m}$.

\section{Egg Cases}

Plate 10 Figure 10-12, Plate 11 Figure 4-5, 7-8 Plate 12 Figure 1-10

Various shapes and sizes, with or without processes and crests and usually an aperture present.

\section{Phylum Foraminiferan linings}

\section{Plate 7 Figure 12, Plate 8 Figure 1-2}

Various, uniserial, biserial or spiral - planispiral or trochospiral. Sizes $75-200+$ $\mu \mathrm{m}$. 


\title{
Arthropod
}

\section{Plate 11 Figure 12}

Conodonts single or in jaw sockets, skeletal remains, claws. Various sizes

\section{$\underline{\text { Unknowns }}$}

\author{
Algal Chains \\ Plate 11 Figure 10-11
}

Spherical, hyaline, grouped together to form chains or clumped together.

\section{Unknown sp. 1}

Plate 12 Figure 11-12

Ovoid with two loops attached opposite, aboral free flowing thin membrane attached. Size $\sim 25 \mu \mathrm{m}$.

\section{Unknown sp. 2}

Plate 11 Figures 1-2

Ovoid, cocoon like single stands coiling in layers. Size $45 \mu \mathrm{m}$.

\section{Unknown sp. 3}

Ovoid shape, no ornamentation, no obvious aperture. Size $25 \mu \mathrm{m}$.

\section{Unknown sp. 4}

Ovoid, dark brown, no ornamentation, wall thick $\sim 1 \mu \mathrm{m}$ narrowing at apical end. Size $50 \mu \mathrm{m}$.

\section{Unknown sp. 5}

Ovoid enlongated central body, pale brown with apical archeopyle, antapical wall narrows and thickens. Size $65 \mu \mathrm{m}$.

\section{Unknown sp. 6}

\section{Plate 11 Figure 6}


Ovoid, brown with apical archeopyle, smooth wall extends antapically into long thin strand. Size $75 \mu \mathrm{m}$.

\section{Unknown sp. 7}

Sub-spherical to ovoid with granulated wall, apical wall narrows. No openings no processes, 2 eyespot markings. Size $125 \mu \mathrm{m}$.

\section{Unknown sp. 8}

Sub-spherical, granulated membrane covers central body and overlaps the edge. Opening appears to be in centre. Size $165 \mu \mathrm{m}$.

\section{Unknown sp. 9}

Breaking up but covered in small proximate processes, shape ovoid to elongate, size $75-85 \mu \mathrm{m}$.

\section{Reworked Pollen}

The terrestrial material recovered in this project contains pollen species which date back as far as the Permian and the Jurassic and there are some samples on the Fan that are void of marine palynomorphs and contain only terrestrial material. This could imply that they have not travelled far enough to be mixed in with the marine material and are outcropping in that area. 


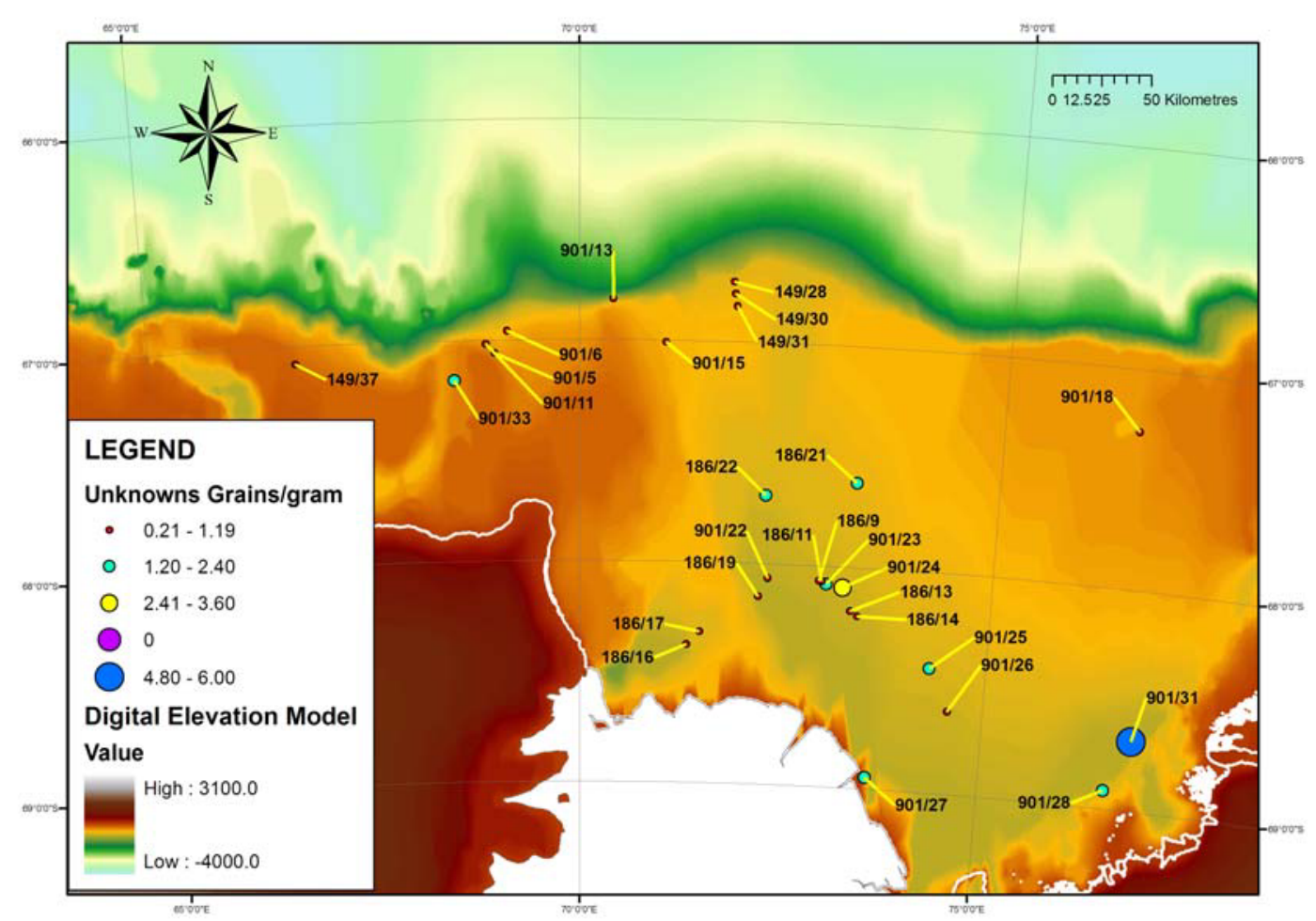

Appendix D: Position of all unknowns grains per gram with highest abundances the larger blue circles as per legend.

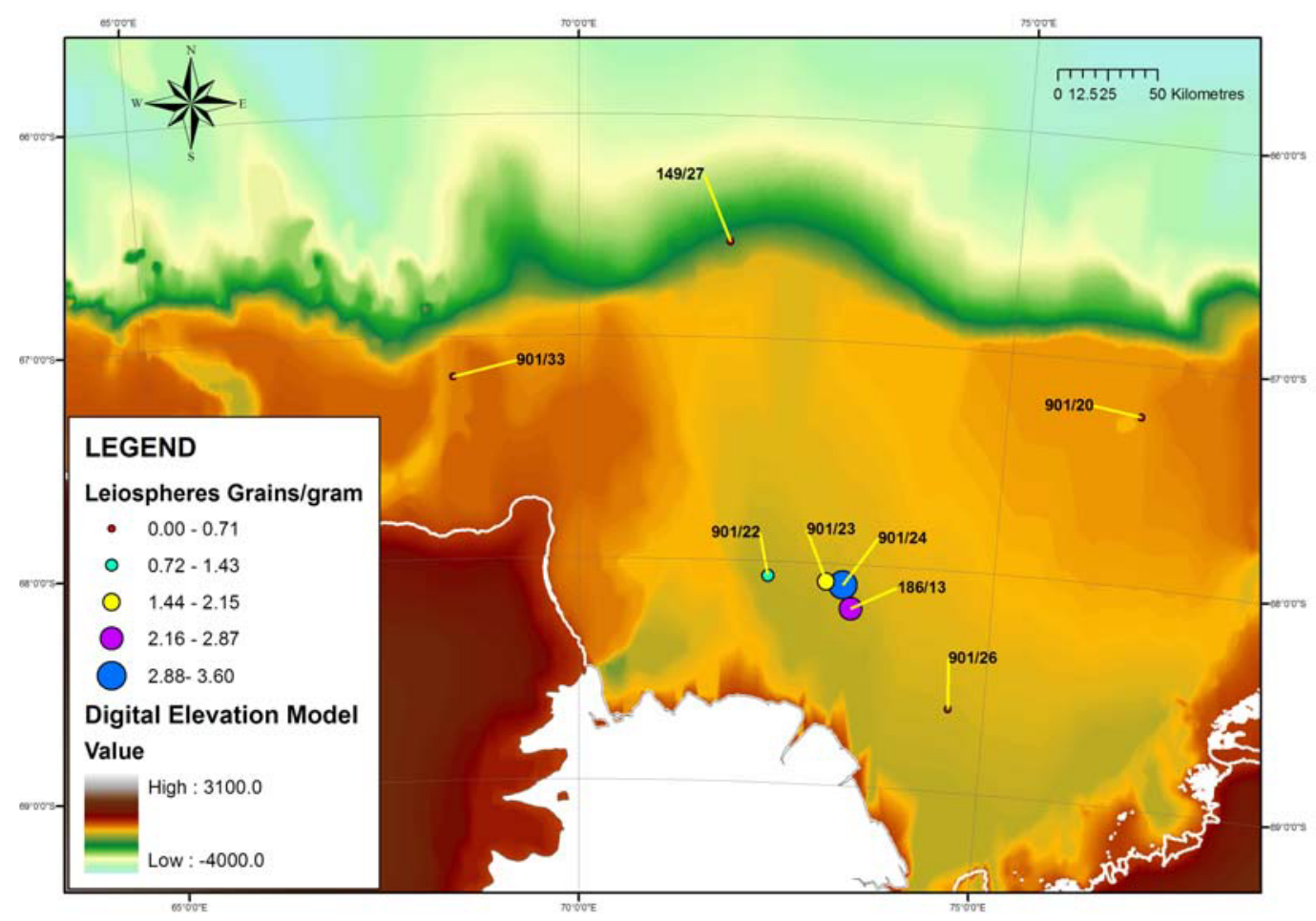

Appendix D: Position of all Leiospheres grains per gram with the highest abundance the larger blue circles and per legend. 


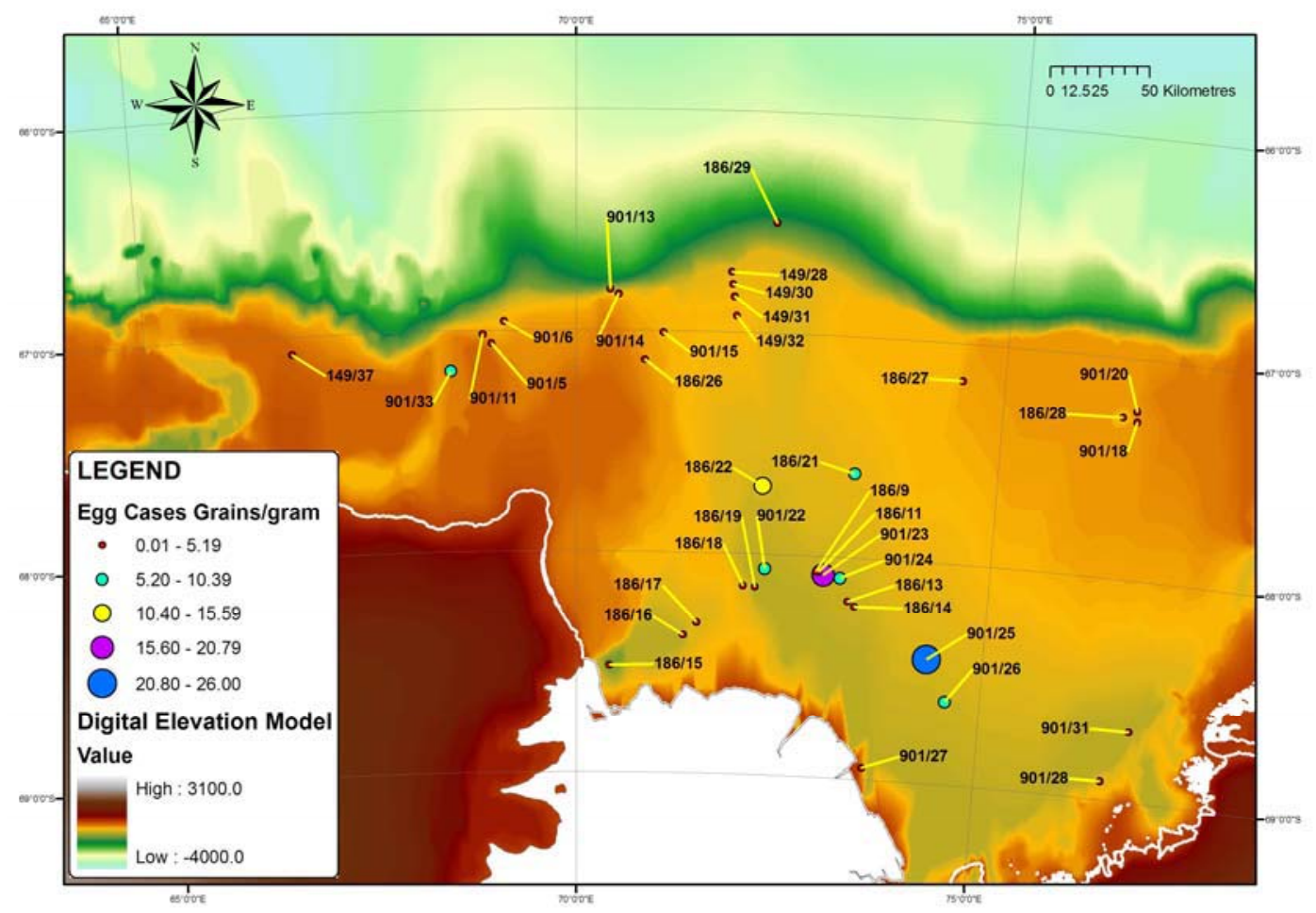

Appendix D: Position of egg cases grains per gram the highest abundance are the larger blue circles.

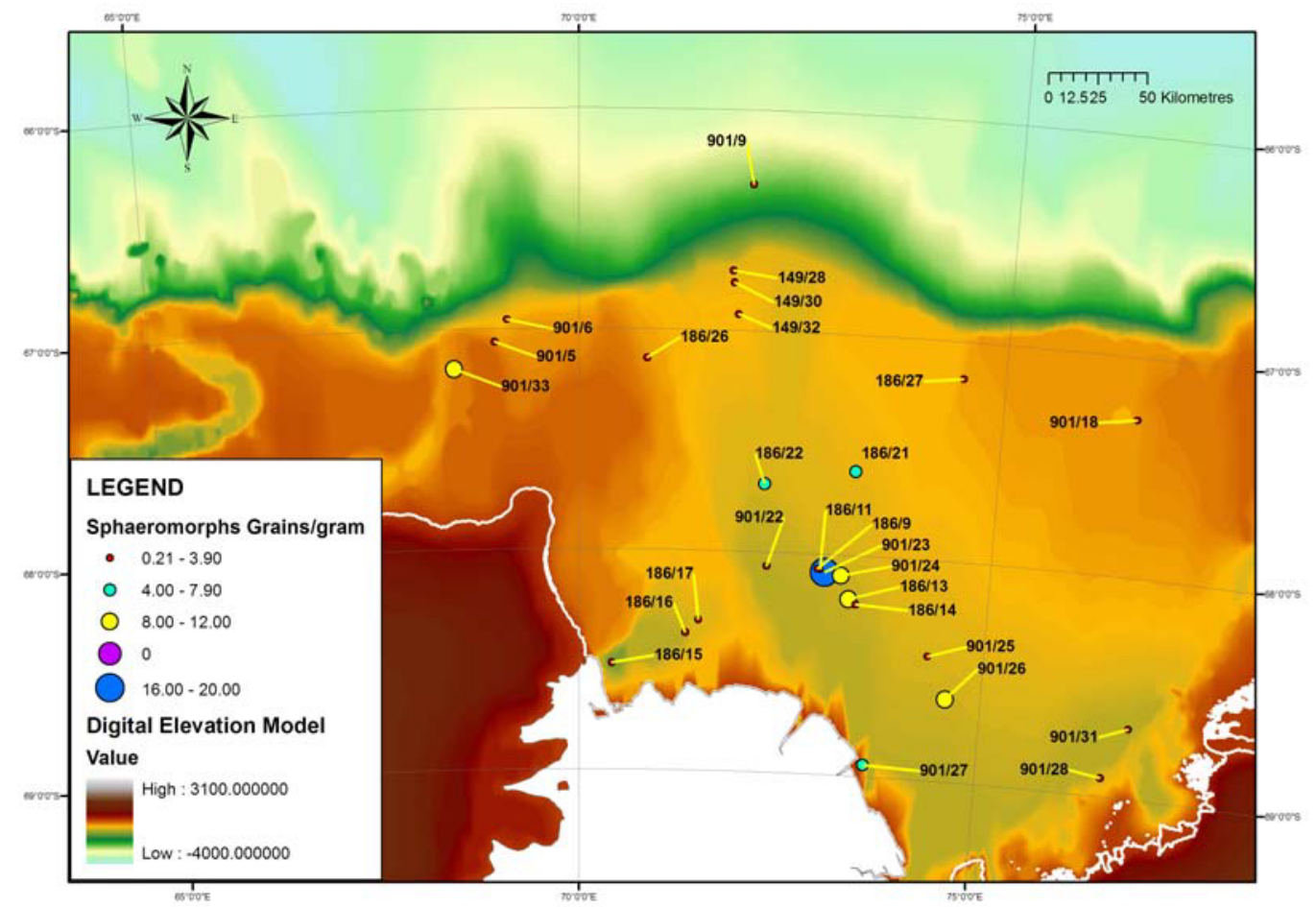

Appendix D: Position of Sphaeromorphs grains per gram the highest abundance are the larger blue circles as per legend. 


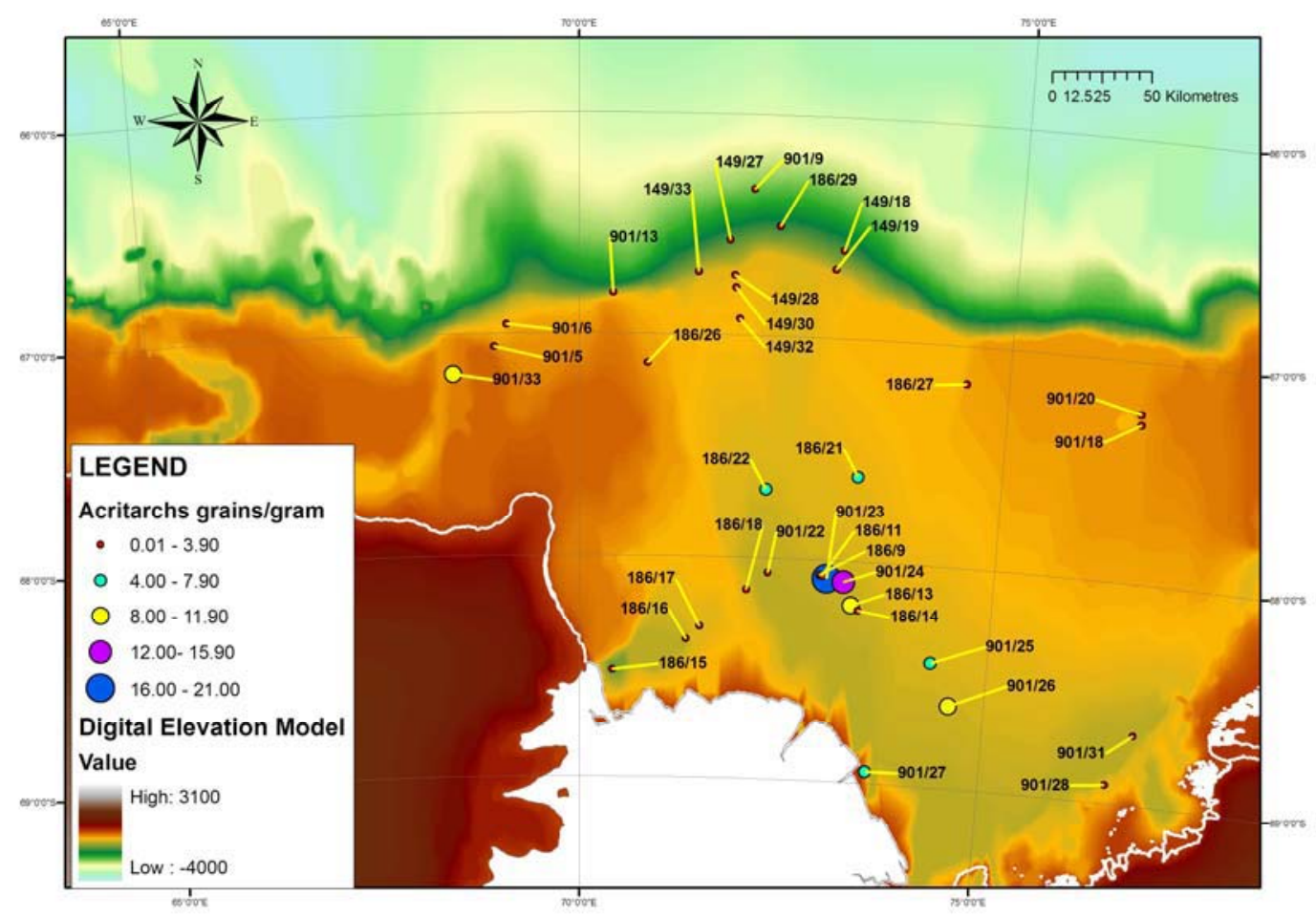

Appendix D: Position of acritarchs grains per gram the highest abundances are the larger blue circles as per legend.

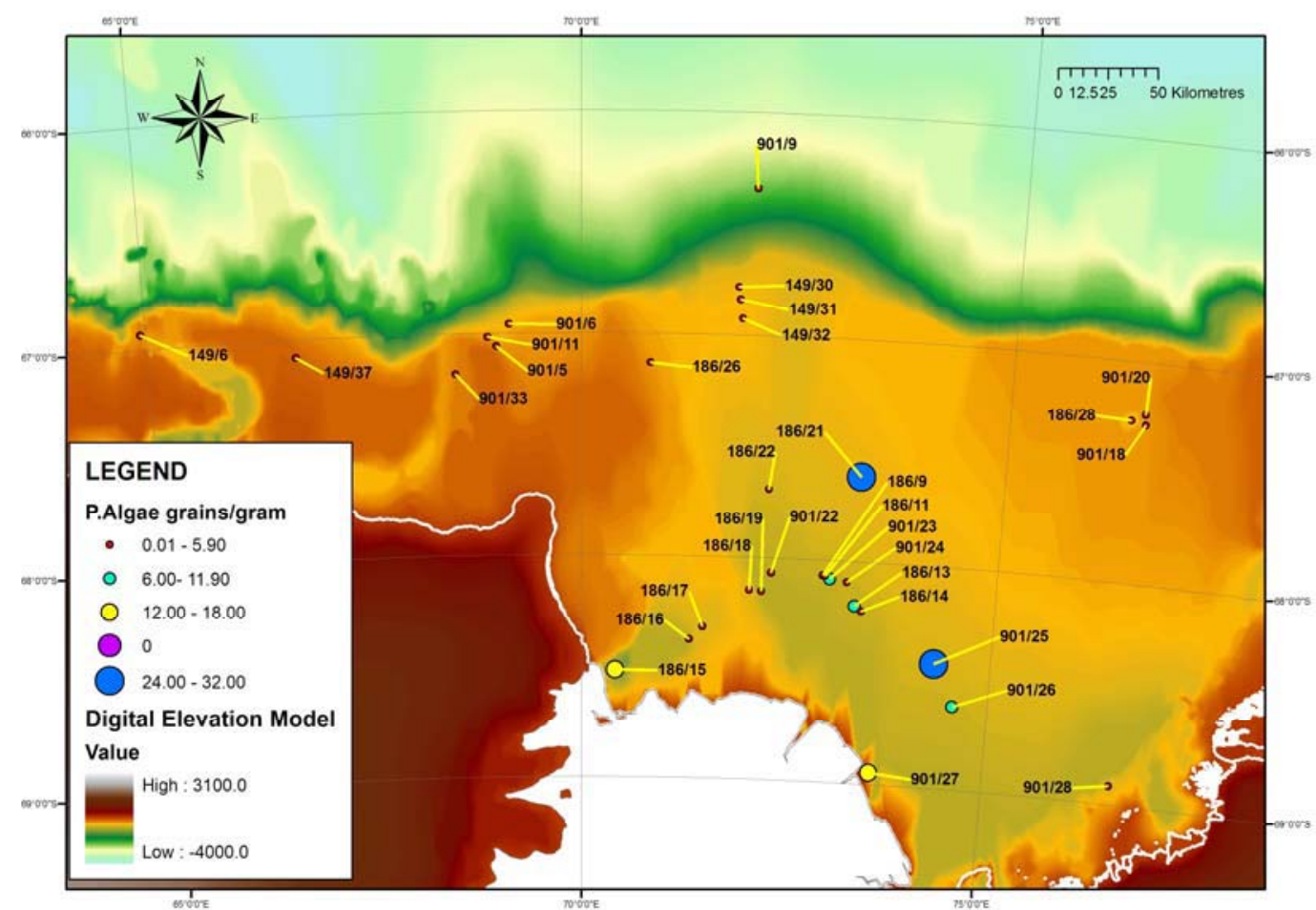

Appendix D: Position of prasinophycean algae grains per gram the highest abundances are the larger blue circles as per legend. 